\title{
Empirical studies on audit quality in the Belgian market for audit services
}

Citation for published version (APA):

van Raak, J. (2011). Empirical studies on audit quality in the Belgian market for audit services. [Doctoral Thesis, Maastricht University]. Universiteit Maastricht. https://doi.org/10.26481/dis.20110527jr

Document status and date:

Published: 01/01/2011

DOI:

10.26481/dis.20110527jr

Document Version:

Publisher's PDF, also known as Version of record

\section{Please check the document version of this publication:}

- A submitted manuscript is the version of the article upon submission and before peer-review. There can be important differences between the submitted version and the official published version of record.

People interested in the research are advised to contact the author for the final version of the publication, or visit the DOI to the publisher's website.

- The final author version and the galley proof are versions of the publication after peer review.

- The final published version features the final layout of the paper including the volume, issue and page numbers.

Link to publication

\footnotetext{
General rights rights.

- You may freely distribute the URL identifying the publication in the public portal. please follow below link for the End User Agreement:

www.umlib.nl/taverne-license

Take down policy

If you believe that this document breaches copyright please contact us at:

repository@maastrichtuniversity.nl

providing details and we will investigate your claim.
}

Copyright and moral rights for the publications made accessible in the public portal are retained by the authors and/or other copyright owners and it is a condition of accessing publications that users recognise and abide by the legal requirements associated with these

- Users may download and print one copy of any publication from the public portal for the purpose of private study or research.

- You may not further distribute the material or use it for any profit-making activity or commercial gain

If the publication is distributed under the terms of Article $25 \mathrm{fa}$ of the Dutch Copyright Act, indicated by the "Taverne" license above, 


\section{Empirical Studies on Audit Quality in the Belgian Market for Audit Services}





\title{
Empirical Studies on Audit Quality in the Belgian Market for Audit Services
}

\author{
PROEFSCHRIFT \\ ter verkrijging van de graad van doctor \\ aan de Universiteit Maastricht \\ op gezag van de Rector Magnificus Prof. mr. G.P.M.F. Mols \\ volgens het besluit van het College van Decanen, \\ in het openbaar te verdedigen \\ op vrijdag 27 mei 2011 om 10.00 uur \\ door \\ Jeroen Johannes Franciscus van Raak
}




\section{Promotor}

Prof. dr. R.H.G. Meuwissen RA

Copromotor

Dr. C.C.M. Schelleman

\section{Beoordelingscommissie}

Prof. dr. A. Vanstraelen (Voorzitter)

Prof. dr. M.A. Carree

Prof. dr. S. J. Maijoor

Prof. dr. M. Willekens (Katholieke Universiteit Leuven) 


\section{Acknowledgements}

Though the following dissertation is an individual work, I could not have completed it without the help, support, guidance and effort of many others. Therefore, I would like to take this opportunity to express my thanks to those who have been very helpful to the development of this dissertation.

First of all, I want to thank my supervisors, Roger Meuwissen and Caren Schelleman. I am grateful for their support, guidance, research ideas, conceptual support and constructive criticism. Their wisdom, knowledge and commitment to the highest standards have provided great inspiration and motivation.

Besides my promotors, I owe gratitude to my advisory committee, Ann Vanstraelen, Martin Carree, Steven Maijoor and Marleen Willekens, for their prompt evaluation of the final manuscript. Each of you offered valuable feedback. Special thanks to Ann Vanstraelen who has provided in-depth reviews of this dissertation at various stages of development. Her suggestions have proven invaluable.

Furthermore, it is a pleasure to thank my current and former colleagues at Maastricht University for their support and advise, and for providing a pleasant working environment. In particular, I want to thank Erik Peek and Rogier Deumes for their research suggestions. I also want to thank my fellow PhD students, Julius André and Mona Offermanns with who I shared countless lunches and coffee breaks in which we discussed many research ideas, as well as slightly less research related topics. I am indebted to my colleagues at Kozminski University who provided me the opportunity to finalize my dissertation.

I also want to express my appreciation to my parents, Frank and Jeannette, my brothers, Mark and Joris, and my sister, Charlotte, who have always supported, encouraged and believed in me. I am grateful to Janneke for the cover design. Finally, I want to thank Magda, for her love, support and constant patience.

Jeroen van Raak, Warsaw, April 2011 



\section{Contents}

Acknowledgements $\quad$ v

Contents vii

1. Introduction 1

1.1 Introduction 1

1.2 Outline 3

1.3 Research setting and data 5

$\begin{array}{ll}1.4 \text { Contribution } & 6\end{array}$

1.5 Structure of the dissertation 8

2. The Use of Audit Partner Expertise as a Risk Management Strategy 9

2.1 Introduction 9

2.2 Prior literature and hypotheses development 11

2.2.1 Client risks and risk management strategies 11

2.2.2 The use of risk management strategies 13

$\begin{array}{ll}2.2 .3 \text { Hypotheses development } & 15\end{array}$

$\begin{array}{ll}2.3 \text { Methodology } & 16\end{array}$

$\begin{array}{ll}\text { 2.3.1 Data } & 16\end{array}$

2.3.2 The Belgian audit market $\quad 17$

$\begin{array}{ll}\text { 2.3.3 Sample selection } & 17\end{array}$

$\begin{array}{ll}2.3 .4 \text { Variables } & 19\end{array}$

2.3.4.1 Dependent variables 19

2.3.4.2 Independent variables $\quad 20$

2.3.4.3 Control variables $\quad 21$

2.4 Results $\quad 22$

2.4.1 Descriptive statistics $\quad 22$

$\begin{array}{ll}2.4 .2 \text { Factor analysis } & 27\end{array}$

$\begin{array}{ll}2.4 .3 \text { Regressions } & 28\end{array}$

$\begin{array}{ll}2.4 .4 \text { Test of hypotheses } & 29\end{array}$

2.4.5 Robustness checks $\quad 33$

2.4.5.1 Logistic regressions 33

2.4.5.2 Local office analysis $\quad 36$

2.4.5.3 Newly acquired clients $\quad 38$

2.5 Conclusions and limitations $\quad 42$

$\begin{array}{ll}2.5 .1 \text { Conclusions } & 42\end{array}$

2.5.2 Limitations $\quad 43$

2.5.3 Future research $\quad 43$

Appendix 2.A 44

Appendix 2.B $\quad 44$

Appendix 2.C 46

$\begin{array}{ll}\text { Notes } & 47\end{array}$ 
3. The Influence of Auditor-Client Economic Bonding on Audit Quality 49

3.1 Introduction

3.2 Prior literature and hypotheses development 52

3.2.1 Audit quality 52

3.2.2 The association between auditor-client economic bonding and audit quality 53

3.2.3 The Belgian setting $\quad 55$

3.2.4 Hypotheses development 57

3.3 Methodology 58

3.3.1 Sample selection $\quad 58$

3.3.2 Model specification $\quad 59$

3.4 Descriptive statistics and results 64

3.4.1 Descriptive statistics 64

$\begin{array}{ll}\text { 3.4.2 Multivariate results } & 67\end{array}$

3.4.3 Strong versus weak economic bonding $\quad 72$

$\begin{array}{ll}\text { 3.4.4 Summary of results } & 74\end{array}$

3.4.5 Robustness checks $\quad 75$

3.4.5.1 Auditor type $\quad 75$

3.4.5.2 Quartiles $\quad 75$

3.4.5.3 Abnormal working capital accruals $\quad 78$

3.4.5.4 Additional tests $\quad 81$

3.5 Conclusion and limitations $\quad 84$

3.5.1 Conclusion 84

3.5.2 Limitations and future research $\quad 84$

Notes $\quad 86$

4. Competition and Quality in the Market for Audit Services 89

4.1 Introduction 89

4.2 Prior literature and hypothesis development 92

4.2.1 Competition and quality in product markets 92

4.2.2 Competition and quality in service markets in general 93

4.2.3 Competition and quality in the audit market 94

4.3 Methodology 96

4.3.1 Sample selection 96

4.3.2 Dependent variable 98

4.3.3 Experimental variables $\quad 99$

4.3.3.1 Experimental variable: Herfindahl index $\quad 100$

4.3.3.2 Experimental variable: market share mobility $\quad 101$

4.3.3.3 Experimental variable: competitor density $\quad 102$

4.3.4 Control variables 104

4.3.5 Regression Models 105

4.3.5.1 Regression model: the effect of market
concentration on audit quality

4.3.5.2 Regression model: the effect of market share
mobility on audit quality
106

4.3.5.3 Regression model: the effect of competitor
density on audit quality 
4.4. Descriptive statistics and results 107

$\begin{array}{ll}\text { 4.4.1 Descriptive statistics } & 107\end{array}$

4.4.2 Multivariate results 110

4.4.2.1 Multivariate results: Herfindahl index 110

4.4.2.2 Multivariate results: market share mobility 114

4.4.2.3 Multivariate results: competitor density 115

4.4.2.4 Multivariate results: summary 116

$\begin{array}{ll}\text { 4.4.3 Robustness checks } & 117\end{array}$

4.4.3.1 Income increasing versus income decreasing earnings management $\quad 117$

4.4.3.2 Abnormal working capital accruals as a proxy for audit quality 120

4.4.3.3 Discretionary accruals weighted by the standard deviation of cash flows from operating activities 121

4.5. Conclusion \& limitations $\quad 126$

4.5.1 Conclusions 126

4.5.2 Limitations and recommendations for future research $\quad 127$ Notes

5. Summary and Discussion 131

5.1 Introduction 131

5.2 Summary of the empirical studies 131

5.3 Conclusions and implications $\quad 134$

5.4 Limitations and suggestions for future research 136

$\begin{array}{ll}\text { References } & 139\end{array}$

Summary in Dutch $\quad 151$

$\begin{array}{ll}\text { Curriculum Vitae } & 155\end{array}$ 



\section{Chapter 1 Introduction}

\subsection{Introduction}

Agency theory provides an explanation for the demand for financial statement audits. Jensen and Meckling (1976) show that capital markets incorporate expectations of self-interested behavior by managers and their effect on firm value in the security prices. This creates incentives for companies to hire external auditors to enhance the credibility of the financial statements. Hence, financial statement audits are used by companies as a monitoring mechanism to reduce the costs that arise from conflicts of interests between managers and shareholders, thereby increasing company value.

The value of the audit in reducing a manager's divergent actions is nevertheless contingent on the quality of the audit (Watts and Zimmerman 1981). Audit quality is a function of auditor competence and auditor independence (DeAngelo 1981b). Auditor competence is positively associated with the probability that misstatements in the financial statements are detected by the auditor. The probability that detected misstatements are reported depends on the independence of the auditor.

Auditors have incentives to provide high quality audits due to possible reputation and litigation costs associated with audit failures. DeAngelo (1981b) argues that failure by an auditor to report material misstatements could harm his reputation, resulting in the loss of future quasi-rents due to client loss. A comparison of auditor reporting behavior in high and low litigious environments by Farmer et al. (1987) shows that litigation concerns also make auditors more likely to report material misstatements. Hence, litigation risk and reputation concerns create incentives for auditors to not compromise audit quality for a single client.

Despite incentives for auditors to deliver high quality audits, a number of major auditing scandals occurred at the beginning of the twenty-first century. These auditing scandals raised concerns about the value and role of audits. In response to the scandals, regulation was put in place to ensure auditor competence and auditor independence. The Sarbanes-Oxley Act, enacted in 2002 , and the revised $8^{\text {th }}$ EU Directive, which came into force in 2006, deal with issues such as auditor rotation, the provision of non-audit services and licensing requirements. These requirements depict a move away from auditmarket self-regulation to increased public oversight.

The recent global financial crisis and the lack of qualified audit opinions issued by auditors preceding the crisis have once again resulted in concerns about auditor competence and auditor independence (Sikka 2009). Regulators currently consider the need for more regulation to maintain audit quality and to enhance confidence of investors in the auditing profession. For example, the Financial Stability Forum (2008) and the Basel Committee 
(2008) suggest the need for further guidance on audit quality. In addition, the Public Company Accounting Oversight Board (PCAOB) currently studies the need for further regulation regarding the assignment of supervision responsibilities within audit firms (PCAOB 2010). The European Commission seeks to answer whether the auditing profession could have done a better job of signaling risks of financial institutions (European Commission 2010). Furthermore, the commission attempts to further the understanding about the effects of audit market structure, audit firm governance and auditor independence on audit quality.

This dissertation consists of three empirical studies which examine factors influencing audit quality. Figure 1.1 displays the relationships between the individual studies. The three studies are related to the two components of audit quality: competence and independence. These are displayed in the middle of the figure. Displayed at the top of figure 1.1, the first empirical study examines whether audit firms use audit partner expertise as a risk management strategy. The second empirical study, displayed in the bottom right corner, tests the effect of auditor-client economic bonding on audit quality and examines whether the effect of auditor-client economic bonding on audit quality depends on the extent of public oversight. The third and last empirical study, displayed in the middle of figure 1.1., examines the relationship between competition on the market for audit services and audit quality.

Figure 1.1: The determinants of audit quality

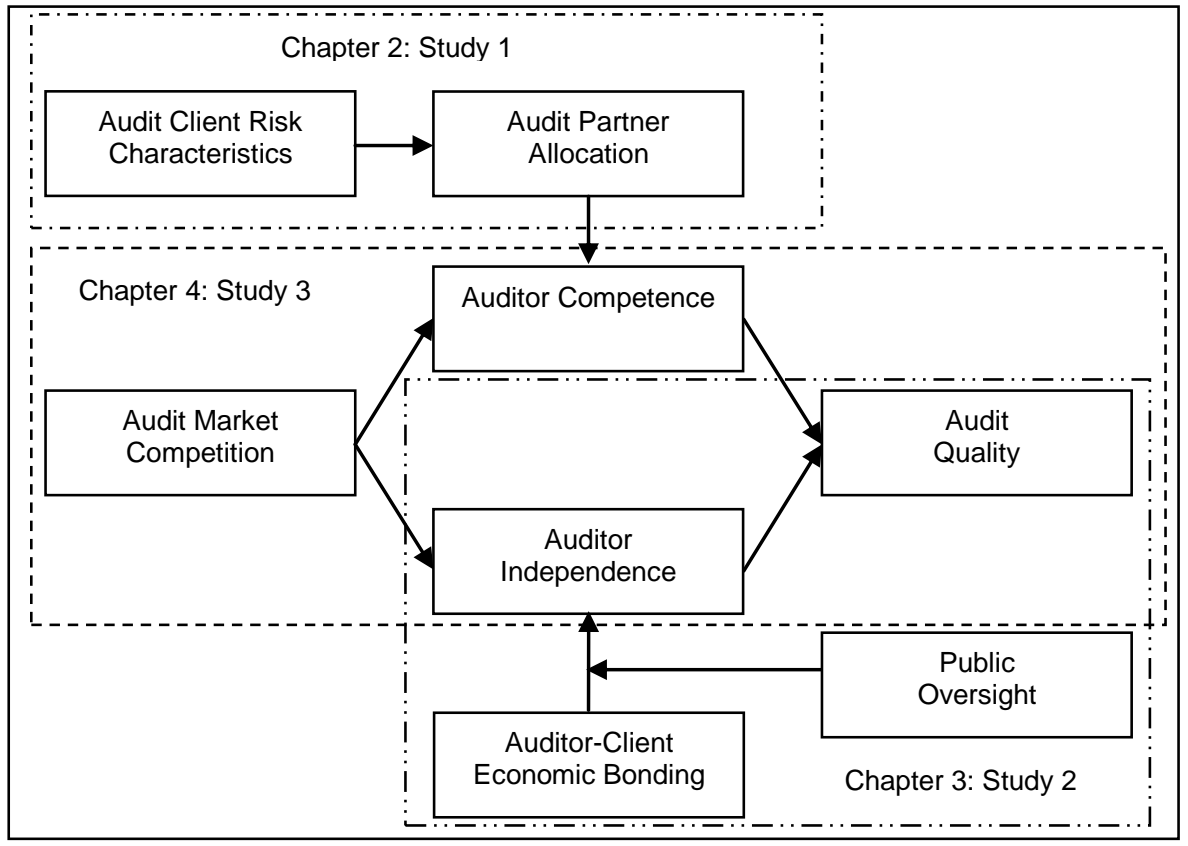




\subsection{Outline}

This dissertation consists of three empirical studies. The first empirical study investigates the use of audit partner expertise as a risk management strategy. Risk management strategies are aimed at reducing the negative impact that audit failures may have on the profitability and reputation of an audit firm. This study focuses on one specific risk management strategy: the use of audit partner expertise. Specifically, the study examines two components of expertise: general partner experience and industry experience. Auditing standards require audit partners to have sufficient general experience and industry experience to audit clients (e.g. ISA 220.14; AU. 312.02). Furthermore, more experienced auditors are found by prior research to be better at detecting material misstatements (e.g. Libby and Frederick 1990). Hence, the allocation of audit partners with greater expertise can be used to manage client risks. Besides this, more experienced partners are shown to use more cost effective approaches when taking action in response to detected material misstatements than less experienced partners (Biggs et al. 1988). Hence, it is important for audit firms to allocate the most experienced audit partners to the most risky audit clients to minimize audit production costs and to manage potential client risks.

Despite the importance of using audit partner expertise as a risk management strategy, it is not clear from a theoretical perspective if audit firms actually use partner expertise to manage client risks for two reasons. First, the allocation of audit partners to clients is a complex task due to differences in partner expertise and client characteristics (Dopuch et al. 2003). This may cause audit firms to not optimally allocate audit partner to clients. Second, due to incentives at the audit partner level, such as risk aversion and career development incentives, the allocation of audit partners to audit clients may not be effective, and audit firms may face risks that are insufficiently managed. Therefore, the study examines whether audit firms allocate audit partners to clients based on client risk characteristics.

The second empirical study analyzes the relationship between auditorclient economic bonding and audit quality. The value of the audit depends directly on the independence of the auditor. An audit conducted by an auditor who is not independent from the client has little to no value for the users of financial statement information. Audit regulation is therefore aimed at ensuring auditor independence, for example by limiting the types of audit and non-audit services that auditors are allowed to provide. Despite the prohibition of many types of non-audit services, the fact that auditors obtain audit fees from the clients they audit may still create an economic bond between the auditor and the client. The economic bond generated by audit fees may cause auditors to never be entirely independent from their clients (Mautz and Sharaf 1961; AICPA 1978; Wallman 1996). While this is unlikely to be an issue for small audit clients, economic dependence on large clients may cause auditors to acquiesce to client pressures to allow earnings management, hence lowering audit quality. However, potential costs due to 
reputation losses and litigation in case of an audit failure create incentives for auditors to remain independent from clients. This study tests whether the negative effect of auditor-client economic bonding on audit quality is offset by litigation and reputation concerns.

The negative impact of auditor-client economic bonding on audit quality is more likely to manifest itself at the audit partner level and the local office level than at the audit firm level because the audit fees obtained from a single client are unlikely to represent a significant part of the total audit fee revenues of an audit firm, while they may represent a substantial part of the revenues of a local office or an audit partner (Wallman 1996; Francis et al., 1999). This study therefore examines the effect of auditor-client economic bonding on audit quality at three levels: the audit firm level, the local office level, and the audit partner level. Furthermore, the study separately examines the effect of auditor-client economic bonding on audit quality for clients that engage in upward earnings management and clients that engage in downward earnings management. Financial statements of clients that engage in downward, hence tax reducing, earnings management are more likely to be inspected by the tax authorities than the financial statements of client that engage in upward earnings management (Vander Bauwhede et al. 2003). Hence, material misstatements are more likely to be detected when clients engage in income reducing than income increasing earnings management. This may induce auditors to be stricter in preventing downward earnings management than upward earnings management. The use of separate analyses based on the direction of earnings management facilitates testing the effect of public oversight on audit quality.

The final empirical study tests the association between competition on the market for audit services and audit quality. Concerns have been voiced about the lack of competition on the market for audit services (e.g. Government Accountability Office 2003). Following standard economic theory, a lack of competition is expected to result in lower quality. Most of the criticism on the audit industry is vested in the structure-conduct-performance framework (S-C-P). High market concentration is generally argued to lead to collusive behavior between the largest suppliers on a market, harming the competitiveness of the market and lowering the provided quality (Yardley et al. 1992). Prior literature has however questioned the suggested association between high concentration levels and a lack of competitiveness on the audit market (Buijink et al. 1998). Furthermore, while economic theory generally argues a positive association between competition and quality, it is unclear whether this holds for the highly regulated market for audit services. Competition may put pressure on audit fees, thereby reducing the incentives for audit firms to invest in quality (Leland 1979; Kranton 2003). Furthermore, competition may impair audit independence, as reduced audit fees may cause auditors to become more dependent upon future quasi rents to offset initial losses (DeAngelo 1981a). Reduced auditor competence and auditor independence could therefore result in reduced audit quality (DeAngelo 1981a). Since the effect of competition on audit quality is unclear, it is important for regulators to obtain insight into the relationship between competition and audit quality. Such insight can help regulators to ensure that 
audit quality is maintained at a high level. The study uses the Herfindahl index, which is adopted from the area of industrial organization, to analyze whether high market concentration levels reflect reduced quality. Furthermore, two measures of competition are used to analyze if audit quality is affected by competition on the audit market. The first measure of competition is based on the market share mobility measure adopted by Buijink et al. (1998). The study develops a second measure of competition to enhance the measurement of local competition.

This dissertation is relevant for both audit practice and audit regulators as it enhances the understanding of factors that influence audit quality. The first study provides further insight into the partner allocation process within audit firms and the extent to which client risks are managed by audit firms. The allocation of audit partners influences auditor competence because audit partner expertise is positively related to the likelihood that material misstatements are detected. The second study provides more insight into the effect of auditor-client economic bonding on audit quality. Furthermore, the second study adds to the current debate on the need for public oversight by analyzing the effect of auditor-client economic bonding on quality using two settings that are characterized by different levels of public oversight. The third study helps to understand the relationships between market concentration, competition and audit quality. Furthermore, it adds to the literature through the development of a new local measure of competition which better takes into account the geographical dispersion of auditors and clients within local audit markets. Together these three studies provide further insight into the main factors that influence audit quality. The contributions of the studies are further discussed in section 1.4.

\subsection{Research setting and data}

Decisions by auditors regarding individual clients are not taken in isolation, but based on the characteristics of the other clients within the auditor's client portfolio (Simunic and Stein 1990). It is therefore important to use a setting in which data is available for the complete set of clients, and not for subsets of clients. Analyses based on complete client portfolios better reflect the actual decision making process within audit firms, thereby providing more insightful results. Therefore, the empirical studies in this dissertation require a setting in which data for a complete market are available. The studies also require the audit firm, the local office and the audit partner to be identifiable for each audit to facilitate the construction of client portfolios at the audit firm level, the local office level and the audit partner level. The first empirical study requires the construction of client portfolios at the audit firm level for the examination of relative client riskiness. Furthermore, it is necessary that proxies for audit partner expertise and client riskiness can be constructed to test whether audit firms allocate audit partners to clients based on client risk factors and audit partner expertise. The second study requires client portfolio data to measure the extent of auditor-client economic bonding. In addition, 
the study relies on the availability of financial client data for the construction of the proxy for audit quality. The third study needs client portfolio data as well as geographic locations of all auditors and clients for the measurement of local competition. Similar to the second study it requires financial client data to measure audit quality.

The Belgian audit market provides an appropriate setting for the studies in this dissertation since it meets all the requirements specified above. Complete portfolios can be constructed because Belgian corporate law requires all companies above a certain size limit to have their financial statements audited by a statutory auditor. These audited financial statements have to be deposited at the National Bank of Belgium (NBB) and are publicly available. Furthermore, all audit reports in Belgium are required to be signed by the name of the audit firm, as well as the name of the engagement partner. This enables the construction of client portfolios at the audit firm level and the audit partner level. Finally, all Belgian auditors are required to be registered at 'het Instituut van de Bedrijfsrevisoren' (IBR, the Belgian Institute of Auditors). This facilitates the collection of audit partner specific data.

The necessary data are obtained from three different sources. Financial client data are obtained from the Bel-First database. This database also lists the audit firm and audit partner for each audited client company. This enables the construction of client portfolios at the audit firm level and the audit partner level. The second dataset consists of annual membership lists of the IBR. These membership lists contain audit partner information, such as the location of the local office at which the audit partner is employed. This facilitates the construction of client portfolios at the office level. Additionally, the IBR membership lists enable the construction of a measure of audit partner expertise. Finally, geographical locations obtained for all audit clients and all local audit offices are obtained from Google Earth. The geographical locations obtained from this database are used to measure local competition.

\subsection{Contribution}

This dissertation contributes to the auditing literature in several ways. First of all, the dissertation examines the determinants of audit quality in a marketwide setting. Whereas prior studies have focused only on publicly listed companies, the studies in this dissertation use data on both publicly listed and privately held companies. The examination of audit processes based on the complete range of clients is important because decisions regarding individual clients are not taken in isolation, but are a function of the characteristics of the other clients within an auditor's client portfolio. More specifically, this implies for the first study that auditor allocation decisions are based on the risk characteristics of all clients within the client portfolio of the audit firm. For the second study this implies that the extent of pressure to allow earnings management depends on a client's importance relative to other clients. For the third study this implies that decisions made with respect 
to individual clients are not a result of just the level of competition faced by the auditor for that particular individual client, but of the level of competition faced for each of the auditor's clients. Hence, each of the three empirical studies will provide more insightful results than studies based on samples of publicly listed clients only.

Second, although listed companies are generally larger than non-listed companies, it is important to analyze the private client segment since nonlisted companies are predominant in the market and constitute the largest part of an auditor's portfolio. An analysis of the private client segment of the audit market is furthermore of interest because this segment of the market is likely to be less concentrated and more competitive than the public client segment (Simunic 1980). It is important to examine auditor behavior in a more competitive environment because auditor behavior may differ based on the degree of competition in a market.

Third, the first study of this dissertation examines the actual allocation of audit partners to clients. Prior research has examined the nature and mix of labor resources used within a single audit firm, as well as the effect of risk on the planned use of experts. However, no study has examined the actual allocation of audit partners as a risk management strategy in a market-wide setting. An examination of actual partner allocation is valuable because the allocation of audit partners is a complex process due to the large variation in client and audit partner characteristics. Hence, the possibility exists that audit partners with greater expertise are not allocated to risky clients even though audit firms recognize that audits of risky clients may benefit from such an allocation.

Fourth, the examination of auditor-client economic bonding on audit quality in a low litigious environment, while taking into account the likelihood that the financial statements will be inspected by tax authorities based on the direction of client earnings management, provides an opportunity to contribute to the literature by providing further insight into the need for public oversight. Specifically, this enables testing whether reputation concerns provide sufficient incentives for auditors to resist client pressure to allow earnings management or whether additional public oversight is needed to prevent auditors from acquiescing to client pressure.

Fifth, the second study of this dissertation uses a relatively new approach by constructing client portfolios not only at the audit firm level, but also at the local office level and the audit partner level. This enables testing the effect of auditor-client economic bonding on audit quality at those levels at which financial dependence on a single client is most likely to result in impaired auditor independence.

Finally, the use of geographical coordinates enables the construction of a new measure of local competition. This measure takes into account the geographical dispersion of auditors and clients within local audit markets, facilitating a more accurate measure of local competition. 


\subsection{Structure of the dissertation}

The remainder of this dissertation is structured as follows. The first empirical study, which analyzes the use of audit partner expertise as a risk management strategy, is presented in chapter 2. The second empirical study, which examines the effect of auditor-client economic bonding on audit quality, forms chapter 3 . Chapter 4 presents the third empirical study, which investigates the association between competition on the market for audit services and audit quality. Finally, chapter 5 concludes by summarizing the dissertation, discussing its limitations and offering suggestions for future research. 


\title{
Chapter 2 \\ The Use of Audit Partner Expertise as a Risk Management Strategy
}

\begin{abstract}
This study examines the use of audit partner expertise as a risk management strategy. Risk management strategies are important, because client risks can result in losses on audit engagements due to litigation, loss of reputation or regulatory penalties. Although there is some prior research that has examined the planned use of experts, to date no study has examined the actual use of experts. This study attempts to address this issue.

The study makes use of Belgian data which facilitates the construction of partner expertise measures. The study examines whether audit firms use audit partner expertise as a risk management strategy for three different types of risk: audit risk, client business risk and auditor business risk.

Results show that audit partner expertise is used as a risk management strategy for clients that pose a higher audit risk or a higher auditor business risk. No evidence is found in support of the hypothesis that audit partners with higher expertise are allocated to engagements with a higher client business risk.
\end{abstract}

Key Words: Risk Management Strategies, Audit Partner Expertise, Partner Allocation.

\subsection{Introduction}

Audit firms use risk management strategies to manage the impact of client risks. There are various risk management strategies which audit firms can use. This study examines whether audit firms use partner expertise as a risk management strategy. Auditors with more expertise can be expected to better detect material misstatements and subsequently better act upon detected material misstatements (Biggs et al. 1988; Bedard and Biggs 1991).

The allocation of partners to clients is a complex task due to differences in partner expertise and client characteristics (Dopuch et al. 2003). From both a risk management and cost minimization perspective it can be reasoned that it is optimal for an audit firm to allocate partners with the greatest expertise to the most risky clients. However, due to possible risk aversion of audit partners and practice development pressure faced by audit partners it is unclear whether the partner allocation in fact occurs in a manner that is optimal for the audit firm. On the one hand, experienced audit partners may be unwilling to audit risky clients due to liability concerns and may use their position in the audit firm to avoid being allocated to such clients. On the other hand, inexperienced partners are more likely to accept such clients in 
order to expand their client portfolio. This can result in risks being insufficiently or not cost effectively managed.

Because of the regulatory requirement to effectively manage client risks (e.g. ISA 220.14; AU. 312.02) and the impact of risk management on audit firm profitability and risk exposure, it is important to test whether audit firms actually allocate audit partners with the greatest expertise to clients that pose increased risk. Therefore, the main research question of this study is: Do audit firms use audit partner expertise as a risk management strategy by allocating partners with more expertise to clients with a higher risk?

Whereas prior literature has tested whether expertise enhances the effectiveness and efficiency of audit decisions (e.g. Libby and Frederick 1990; Biggs et al. 1988; Bedard and Biggs 1991), examined the nature and mix of labor resources used within a single firm (e.g. O'Keefe et al. 1994; Hackenbrack and Knechel 1997) and investigated the effect of risk on the planned allocation of expert personnel (e.g. Johnstone and Bedard 2003; Bedard and Johnstone 2004), no study has tested whether audit firms take client risks into account in actual partner allocation decisions. The current study contributes to the audit literature in at least two respects. First, this study examines the actual allocation of audit partners across clients, as opposed to prior research which investigated the planned allocation of audit partners. Since the auditor allocation process is complex due to a large variety in audit partner and client characteristics, it is important not only to examine if a need for partners with greater expertise was indicated, but also whether such partners were actually allocated to clients that pose greater risks. Second, this study examines the actual allocation of audit partners across clients in a market wide setting. Prior research relied on data from listed clients only. However, auditors consider client risk in a portfolio setting, taking not only risk characteristics of individual clients into account, but also risk characteristics of the other clients in the client portfolio (Simunic and Stein 1990). Hence, it is important for an analysis of client risks to incorporate both listed and non-listed clients in the construction of client portfolios to better reflect the processes that take place within audit firms. Furthermore, audits of both listed and non-listed companies enhance auditor expertise. A measure of auditor expertise based on both listed and non-listed clients will therefore be more accurate than a measure of partner expertise based on listed clients only.

This study is conducted in the Belgian audit market, a setting in which it is possible to construct complete client portfolios for each audit firm, including both listed and non-listed client companies. Furthermore, for each audit firm it is possible to construct expertise measures for all audit partners. To reduce the confounding impact of other potential risk management strategies, this study makes use of a sample of companies for which a new partner was assigned, while still audited by the same audit firm. This setting enables testing whether clients that pose greater risks are audited by audit partners with a greater level of expertise.

The current study tests the use of audit partner expertise as a risk management strategy for three types of risks that are commonly distinguished in the auditing literature: audit risk, client business risk, and auditor business 
risk (Huss and Jacobs 1991). Furthermore, two components of partner expertise are distinguished: general partner experience and industry experience. The results support the expectation that audit firms use partner expertise as a risk management strategy. Partners of both Big $\mathrm{N}$ and non-Big $\mathrm{N}$ audit firms with greater general experience are allocated to clients with greater auditor business risk. Industry experience of partners is found to be used to manage audit risk. Furthermore, there is some evidence that non-Big $\mathrm{N}$ audit firms allocate partners with greater general experience to clients with greater audit risk. No support is found for the use of partner expertise as a risk management strategy for client business risk.

The remainder of this study is structured as follows. Section 2.2 discusses relevant prior literature and hypotheses development. Section 2.3 describes the data required to conduct the current study and outlines the research methodology. Section 2.4 presents the results of the analyses. Finally, section 2.5 provides the conclusion and limitations.

\subsection{Prior literature and hypotheses development}

This section provides an overview of relevant prior literature. First, the various types of client risks are described. This is followed by a discussion of the importance of risk management strategies. Subsequently, possible risk management strategies are described, along with an overview of prior research on these risk management strategies. Finally, based on this discussion, the hypotheses for this study are outlined.

\subsubsection{Client risks and risk management strategies}

Because a single client can cause significant costs to an audit firm in case of bankruptcy or audit failure, it is important for an audit firm to manage client risks, while taking into account the audit fee (e.g. Johnstone and Bedard 2003) and the risk characteristics of other clients (Simunic and Stein 1990).

Prior literature has identified various types of risks which clients can pose to auditors, using different risk classifications. The current study relies on the commonly used risk classification provided by Huss and Jacobs (1991). They distinguish three types of risk that are relevant for audit firms in client acceptance decisions and for the audit process in general: client business risk, audit risk, and auditor business risk. The first type of risk, client business risk, is related to client profitability and continuity. Client business risk is defined as "the risk that an entity's business objectives will not be attained" (Bell et al. 1997, p.15). The second type of risk, audit risk, refers to "the risk that the auditor may unknowingly fail to appropriately modify his or her opinion on financial statements that are materially misstated" (AICPA 2006, AU. 312.02). The last considered type of risk, auditor business risk, relates to the risk that an auditor incurs "loss or injury to his or her professional practice from litigation, adverse publicity, or other events arising in connection with financial statements audited and reported on" (AICPA 2006, AU 312.02, footnote 2). 
Auditing standards require audit firms to appoint audit teams to engagements in such a way that an audit team has a sufficient amount of experience to manage these types of risk. The International Standards on Auditing (ISA 220.14) require that "[t]he engagement partner shall be satisfied that the engagement team, and any auditor's experts who are not part of the engagement team, collectively have the appropriate competence and capabilities to perform the audit engagement in accordance with professional standards and applicable legal and regulatory requirements, and enable an auditor's report that is appropriate in the circumstances to be issued". ISA 220.A11 draws further attention to the experience component of an engagement team, requiring that an engagement team has an: "understanding of, and practical experience with, audit engagements of a similar nature and complexity through appropriate training and participation".

The need to manage client risks also follows from the audit risk model (AICPA 2006, AU. 312.02). According to the audit risk model, audit risk is a function of the risk of material misstatements and the detection risk, where the risk of material misstatements is the product of inherent risk and control risk. Inherent risk refers to the probability that the financial statements contain a material misstatement, assuming that there are no related controls. Control risk refers to the risk that material misstatements are not detected by the client's internal control system. Detection risk refers to the probability that the auditor fails to detect a material misstatement that has not been detected by the client's internal control system. From this it follows that in cases of increased inherent risk and increased control risk (weaker internal control system) an auditor will have to lower the detection risk to maintain audit risk at an acceptable level (e.g. Simunic 1980). Detection risk is lowered by increasing audit effort. Given a desired audit risk level, a higher detection risk (less audit effort) is acceptable when inherent risk and control risk are low. Hence, from the audit risk model it follows that an audit firm has to appropriately adjust its audit effort based on the degree of audit risk.

Apart from merely managing these three types of client risk, it is also important for the audit firm to manage these in a cost effective manner. Assuming audit firms participate in a competitive market and given a scarcity of expert staff, audit firms will face a cost minimization problem not only at the individual engagement level (e.g. O'Keefe et al. 1994), but also at the overall firm level. Even though clients at all risk levels might benefit from having an experienced engagement partner, it is optimal for audit firms to assign partners with the highest expertise to clients with the greatest risks, since audits of such clients benefit most from more partner expertise (Biggs et al. 1988; Libby and Frederick 1990; Bedard and Biggs 1991). The assessment of client risk factors will therefore not only influence the assignment of labor within, but also across engagements (Bell et al. 1997). The diversity in knowledge of audit partners, and the fact that client characteristics show a lot of variation, make the allocation of audit partners to clients a complex, but important task (Dopuch et al. 2003).

The audit partner allocation process is further complicated by the degree of risk aversion of the engagement partner. The engagement partner is the leader of the audit team conducting the audit and bears final responsibility in 
case of an audit failure. Because audit partners are personally accountable for any liabilities arising from engagements for which they are the engagement partner, they are likely to be reluctant to audit risky clients. Partners with the greatest experience may therefore use their power within the firm to influence the client allocation process, in order to avoid being allocated to risky clients. ${ }^{1}$ Besides that, less experienced audit partners, faced by career concerns, may have incentives to accept risky clients, as practice development is an important factor in promotion and compensation decisions (Hooks et al. 1994). This may result in a sub-optimal use of expertise as a risk management strategy, which may leave audit firms with risks that are insufficiently, or not cost effectively managed.

\subsubsection{The use of risk management strategies}

Audit firms can use a number of strategies to manage client risks, such as increasing audit effort (Schelleman and Knechel 2010), screening out clients with a high litigation risk (Francis and Reynolds 2001; Shu 2000; Choi et al. 2004) or poor management integrity (Johnstone and Bedard 2004; Asare et al. 2005), charging a risk premium (e.g. Pratt and Stice 1994; Houston et al. 1999; Seetharaman et al. 2002; Johnstone and Bedard 2003; Asare et al. 2005), negotiating adjustments of the financial statements with clients (Francis and Krishnan 1999), reporting more conservatively (i.e. lowering the threshold for issuing a modified audit report) (Thoman 1996; Willekens and Vander Bauwhede 2004), changing the nature and timing of audit procedures (Bell et al. 2002), and using expert personnel (e.g., O'Keefe et al.1994; Hackenbrack and Knechel 1997; Johnstone and Bedard 2001; Johnstone and Bedard 2003; and Asare et al. 2005). Since the latter strategy is most closely related to that examined in the current study, research on this strategy is discussed more elaborately below.

A number of studies use an experimental approach to test the effect of expertise on the effectiveness of the audit (e.g. Libby and Frederick 1990; Biggs et al. 1988; Bedard and Biggs 1991; Owhoso et al. 2002). Libby and Frederick (1990) find evidence suggesting that experienced auditors are more accurate and more efficient in explaining audit findings and that they are able to provide more plausible reasons for audit findings compared to less experienced auditors (measured in years of auditing experience). Using the verbal protocol technique, Biggs et al. (1988) and Bedard and Biggs (1991) report similar findings using an experience classification based on rank (seniors relative to managers). Biggs et al. (1988) further report that while inexperienced auditors respond to finding a potential problem by increasing the audit effort in all stages of the audit, experienced auditors seem to be more selective, suggesting a more cost effective approach towards handling audit problems. An experimental study by Owhoso et al. (2002) shows that partners with industry expertise are more likely to detect errors than partners without industry expertise. These studies help to understand the benefit of allocating personnel to clients based on the client risk profile and the partner's level of expertise. 
In addition to the experimental studies discussed in the previous paragraph, there are a number of studies that use archival data to examine whether auditors plan to assign more experienced personnel to riskier clients. The first insights on how audit firms alter actual audit plans based on client characteristics are provided by Bedard (1989). Through a survey of workpapers, her archival study shows that audit plans are relatively unchanged from year to year. ${ }^{2}$ Mock and Wright (1993) confirm these results, and additionally find limited evidence that the extent of planned testing is positively related to inherent risk. Quadackers et al. (1996) show that the planned extent of substantive testing is only adjusted for clients that exhibit large changes in risk. Mock and Wright (1999) report a moderately positive association between changes in client risk factors and the nature of planned tests, but find no association between changes in client risks and the amount of testing. Davidson and Gist (1996) find that the total number of planned audit hours is positively related to inherent risk, control risk, client business risk, client size, and client complexity. Overall, these studies show that audit plans are influenced by client risk factors, but that audit firms are slow in revising audit plans to reflect changes in client risks.

A number of studies add to the literature by disaggregating the number of hours spent across different levels of expertise. These studies examine whether client risks are reflected in the planned allocation of expert staff. O'Keefe et al. (1994) find that more hours of expert staff are assigned to clients with a higher client business risk, but find no support for the hypothesis that the level of inherent risk has an effect on the number of hours spent on an engagement by managers or partners. Hackenbrack and Knechel (1997) add to this by showing that audit firms plan to use relatively more hours of high grades of labor to clients with a higher auditor business risk. Johnstone and Bedard (2001) report that audit firms plan to allocate personnel with a greater level of expertise to clients with a higher audit risk. Johnstone and Bedard (2003) find further evidence that audit firms manage audit risk by planning to assign expert personnel, but find no evidence supporting the argument that audit firms plan to use expert personnel to manage client business risk and auditor business risk. Results from an experimental study by Asare et al. (2005) show that audit firms allocate relatively more experienced staff to clients with a high inherent risk. Ettredge et al. (2009) show that economies of scale allow bank specialist auditors to charge lower audit fees, on average, to bank clients. Furthermore, their results suggest that compared to non-specialist auditors, bank specialist auditors spend relatively more time auditing less verifiable fair value accounts, which require more auditor judgment. Hence, audits appear to benefit from the allocation of specialist auditors.

Overall, prior literature has found a weak association between client risk factors and the number of audit hours planned to an engagement. Stronger results are found when taking the level of staff expertise into account, although it still remains unclear for which types of risk the use of partner expertise is an appropriate risk management strategy. Building on prior literature, the current study examines the use of audit partner expertise as a risk management strategy for each of the risk categories. 


\subsubsection{Hypotheses development}

The prior discussion shows that audit firms are required by auditing standards to sufficiently manage client risks. Furthermore, there are economic reasons for audit firms to manage the potential impact of client risks. However, due to the complexity of the partner allocation process, as well as risk aversion of audit partners, it remains an empirical question whether audit firms use partner expertise as a risk management strategy. Since the viability of the use of expert personnel as a risk management strategy is likely to depend on the type of risk (as suggested by Johnstone and Bedard 2003), and because of the mixed evidence so far, separate hypotheses are formulated for the three risk categories as identified by Huss and Jacobs (1991): audit risk, auditor business risk, and client business risk. Each hypothesis follows the argumentation that audit firms use partner expertise as a risk management strategy.

The first hypothesis tests whether audit firms use partner expertise as a risk management strategy for audit risk.

Hypothesis 1: Ceteris paribus, audit firms are more likely to allocate a partner with more expertise to a client with a higher audit risk than to a client with a lower audit risk.

The second hypothesis examines whether audit firms use partner expertise as a risk management strategy to manage client business risk.

Hypothesis 2: Ceteris paribus, audit firms are more likely to allocate a partner with more expertise to a client with a higher client business risk than to a client with a lower client business risk.

The final hypothesis examines the use of audit partner expertise as a risk management strategy for clients with a higher auditor business risk:

Hypothesis 3: Ceteris paribus, audit firms are more likely to allocate a partner with more expertise to a client with a higher auditor business risk than to a client with a lower auditor business risk.

The next section describes the methodology which this study uses to test these hypotheses. 


\subsection{Methodology}

This section describes the methodology used to test the hypotheses stated in the previous section. First, the data requirements for testing the research question are described. Subsequently, it is explained why the Belgian audit market is chosen as a setting for this research. This is followed by a description of characteristics specific to this audit market. Next, the sample selection is discussed. This section concludes by providing an overview of variables which are used to measure audit partner expertise and client characteristics.

\subsubsection{Data}

To be able to test the hypotheses as stated in the previous section, there are a number of data requirements. First of all, client financial information is required to construct proxies for the client risk factors. Second, for every client company in the sample the audit firm should be known because relevant client portfolios per firm have to be constructed. This is necessary to compare the risk profile of one client to that of the risk profiles of the remaining clients of the same audit firm to test whether audit firms allocate partners with (relatively) more expertise to (relatively) riskier clients. Third, for every engagement the name of the audit partner should be identifiable. Finally, a measure of audit partner expertise should be available for each auditor in the market. The last two requirements are necessary to be able to relate a client's risk profile to the expertise of an audit partner.

The Belgian audit market provides an appropriate setting for this research for a number of reasons. First of all, in Belgium audit reports have to be signed with both the name of the audit firm and the name of the responsible audit partner. This makes it possible to construct client portfolios at both the firm and the partner level. Second, all auditors in Belgium are required to be registered at the Belgian Institute of Auditors (IBR, 'Instituut van de Bedrijfsrevisoren'). The Belgian Institute of Auditors has published annual membership lists from 1961 onwards, which allow computing the number of years of experience of each auditor in Belgium. Appendix A gives a more extensive overview of the IBR membership lists and steps taken to match audit partners to the appropriate audit firm. In addition, the possibility to construct client portfolios at the partner level provides the opportunity to construct an alternative measure of expertise, which is industry experience. Finally, it is possible to collect the required financial information for all Belgian companies using the Bel-First database. With this financial data it is possible to construct proxies for audit risk, client business risk and auditor business risk for each audited company.

The possibility to construct relevant portfolios per firm and per partner, to measure expertise, and to construct risk proxies for every audited company make the Belgian audit market a unique and appropriate setting to examine the use of partner expertise as a risk management strategy. 


\subsubsection{The Belgian audit market}

In many ways the Belgian market for audit services is different from the US market. Belgium has a code-law tradition, a French legal origin, a strong legal enforcement, a high ownership concentration, but low outside investor rights and a stock market which is of limited importance (LaPorta et al. 1997; LaPorta et al. 1998; Leuz et al. 2003; Vander Bauwhede and Willekens 2004). ${ }^{3}$ Most companies in Belgium are privately held and family-owned. Further, Belgium is a country with a low litigious environment, in which hardly any litigation exists against inappropriate audit reporting (Gaeremynck and Willekens 2003).

Although Belgium has a low litigious environment, there are still sufficient other mechanisms to ensure that audit quality remains at a sufficiently high level, e.g. three year mandates ${ }^{4}$, disciplinary actions against auditors, investigations in audit firms, and peer reviews (Gaeremynck and Willekens 2003). In addition, even though the risk of litigation is low, auditors still face the risk of loss of reputation (Klein and Leffler 1981) and loss of quasi rents (DeAngelo 1981b).

Figure 2.1 gives an overview of the development of the Belgian audit market. It shows a steady increase in the number of auditors, which stabilized around 1998 at just below 1,000 auditors. The major increase in the number of auditors around 1984 was due to a change in regulation, requiring all auditors to be registered with the national institute of auditors (IBR).

\subsubsection{Sample selection}

As discussed, data for this study are collected from two separate sources. Financial data are collected using the Bel-First database, and partner information is collected using the IBR membership lists. Financial data and auditor information (i.e. the name of the audit firm and the audit partner) for the

Figure 2.1: The number of auditors in the Belgian audit market, 1956-2006

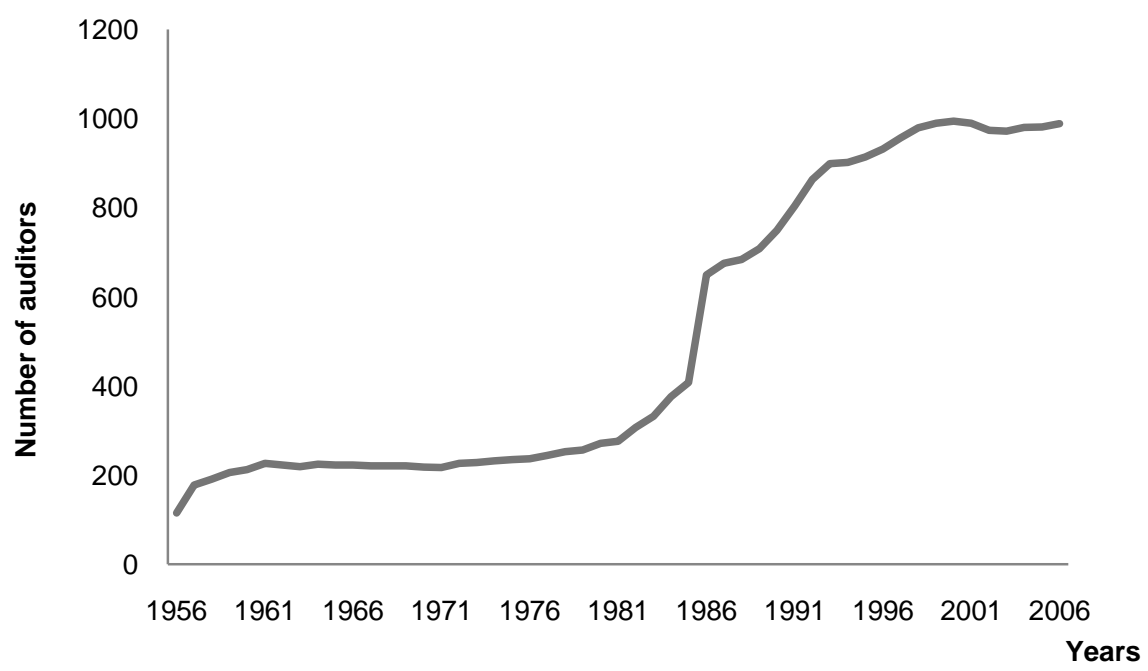


Table 2.1 - Panel A: Sample selection (company-year observations)

\begin{tabular}{lrc}
\hline A) Initial Sample & & 167,379 \\
Less: Utilities and Financial Institutions & $-11,675$ & \\
Less: Subsidiaries & $-18,004$ & $-56,490$ \\
Less: Missing values & $-6,480$ & 74,730 \\
Less: More than one audit partner & & \\
B) Full Sample & $-13,343$ & $-15,845$ \\
Less: Sole Proprietorships & $-40,036$ \\
Less: Lack of prior year auditor information & $-2,758$ \\
Less: No change in audit partner & -194 & \\
Less: Switch to another audit firm & & 2,554 \\
Less: Audit firms with only one partner accepting new clients & & \\
C) Sample for analyses (change sample) &
\end{tabular}

Table 2.1 - Panel B: Number of observations per year

\begin{tabular}{lcc}
\hline Year & Full Sample & Change Sample \\
1998 & 7,862 & -- \\
1999 & 8,014 & 311 \\
2000 & 8,171 & 290 \\
2001 & 8,358 & 281 \\
2002 & 8,298 & 227 \\
2003 & 8,348 & 417 \\
2004 & 8,498 & 359 \\
2005 & 8,643 & 366 \\
2006 & 8,538 & 303 \\
Total & 74,730 & 2,554 \\
\hline
\end{tabular}

complete audit market are available in the Bel-First database from 1998 onwards. The most recent year for which financial data was available at the start of the study is 2006. Partner experience is measured using the membership lists of the Belgian institute of auditors, which are published annually from 1961 onwards. Therefore the sample is limited to company observations for the years 1998-2006. This section discusses the sample selection. More information about the steps taken to prepare the data for this research can be found in the appendices.

As mentioned, audit firms can adopt various risk management strategies, which could act as substitutes. In order to reduce the likelihood that alternative risk management strategies could confound the results, a setting is used in which the use of other risk management strategies is minimized, and in which therefore the use of audit partner expertise as a risk management strategy is most likely to occur. Therefore a subsample of client companies is used for which the audit partner changed, but the audit firm did not. While the reason for the change in partner could vary, this setting creates an opportunity to test whether a partner with more (less) expertise is allocated to clients with higher (lower) risk. ${ }^{5}$

In total, 28,735 unique companies are available for 1998-2006, resulting in 167,379 company-year observations. From this initial sample, observations are removed for the following reasons (see also Panel A of Table 2.1):

- Due to their specific audit requirements and circumstances, utilities (four digit NACE industry codes between 4000 and 4,100) and financial institutions (four digit NACE-codes between 6500 and $6720)$ are excluded from the sample $(n=11,675)$. 
- Subsidiaries are removed from the sample because audit partner allocation may be driven by decisions of the parent company, and not by characteristics of the subsidiary $(n=18,004)$.

- Observations with missing values were removed $(n=56,490)$. Most of these are removed because of missing financial information for the current or prior fiscal year $(n=53,602)$. The other 2,888 observations were removed because the audit partner was not identified in the Bel-First database.

- Observations with more than one audit partner are removed $(n=6,480)$ because the assignment of multiple partners may already be considered to be a risk management strategy. ${ }^{6}$

- Observations for which the audit firm is a sole proprietorship (i.e. a firm with only one auditor partner) are removed $(n=13,343)$ because these firms cannot allocate auditors to clients based on client risk.

- Observations are removed for which no auditor information is available for the prior fiscal year, either because the company was not included in the database before, or because of omission for one or more years $(n=15,845)$. In these cases it is impossible to determine if or when a partner change occurred.

- Company observations that continued to be audited by the same partner were removed $(n=40,036)$ because in these cases no allocation decision takes place.

- Companies that switched to another audit firm were also removed $(n=2,758)$ because it is possible that the partner who attracted the new client becomes the engagement partner, without a formal allocation decision taking place.

- Finally, 194 observations were removed from the sample because for these observations there was only one partner in the audit firm accepting re-allocated from within the same firm, making it impossible to measure relative partner expertise. ${ }^{8}$

The final sample consists of 2,554 company-year observations $(2,222$ unique companies). An overview of the remaining observations, per fiscal year, is given in Panel B of Table 2.1, which shows that the number of observations is quite evenly distributed across the sample years.

\subsubsection{Variables}

This section discusses the measurement of the dependent and independent variables.

\subsubsection{Dependent variables}

Experience is commonly assumed to be a primary determinant of improved expertise (e.g. Hamilton and Wright 1982; Bonner and Lewis 1990; Marchant 1990). However, Bonner and Lewis (1990) argue that even though it is common to measure expertise based on experience, it is an incomplete measure of expertise. ${ }^{9}$ Therefore two measures of expertise are used. The first measure of expertise is general partner experience. The second meas- 
ure of expertise, suggested by Bonner and Lewis (1990) and commonly used in auditing research, is industry experience.

The first dependent variable, GENERAL_EXPERIENCE, is defined as the number of years since the auditor has obtained his or her certification as certified public accountant. ${ }^{10}$

The second dependent variable is INDUSTRY EXPERIENCE . While $_{i}$ prior studies commonly measure industry experience at the level of the audit firm, Francis et al. (2005) argue that industry experience partly resides in individuals. The audited assets of a client is a commonly used proxy for the revenues derived by an audit firm from a client, and are an appropriate measure, because auditing is an inherently balance sheet oriented activity (Caplan and Raedy 2005). Prior studies report a non-linear relationship between client size and audit fees derived from a client (e.g. Simunic 1980). Therefore, partner industry experience is measured as the ratio of the sum of the natural logarithms of total assets from clients within industry (i), divided by to the sum of the natural logarithms of total assets from all clients in all industries which were audited by the partner in the last year. ${ }^{11}$ An overview of the number of observations per industry is provided in Appendix C.

\subsubsection{Independent variables}

Prior research has used a number of different variables to proxy for audit risk, client business risk and auditor business risk (e.g. Simunic and Stein 1996; Krishnan and Krishnan 1997; Shu 2000; Francis and Reynolds 2001; Choi et al. 2004; Hay and Jeter 2008). This section describes the variables that are relevant to the current setting.

A number of variables are used in prior literature to proxy for audit risk. ${ }^{12}$ Receivables and inventory are typically accounts that are difficult to audit, and where financial statement misstatements occur often (Feroz et al. 1991), hence requiring subjective judgments by auditors (Simunic 1980). Therefore, a first risk measure that is used to proxy for audit risk is the sum of inventory plus receivables, scaled by total assets (IRTA) (see Simunic 1980; Krishnan and Krishnan 1997; Francis and Reynolds 2001; Gaeremynck and Willekens 2003). A positive association between IRTA and partner expertise is expected.

Another comparable measure that is commonly used in previous studies to proxy for audit risk is the ratio of current assets over total assets (CATA), where a higher ratio indicates a higher audit risk (Ferguson, Francis and Stokes 2003; Francis, Reichelt and Wang 2005; Ferguson et al. 2006; Hay and Jeter 2008). A higher value for CATA is expected to be associated with greater partner expertise.

Asset Turnover (TURN) is measured as the ratio of sales to total assets. A higher turnover indicates a lower client business risk (Francis and Reynolds 2001), but also a higher transaction complexity and is associated with more audit effort (Chaney et al. 2004). This variable could therefore be associated with either client business risk or audit risk. The effect of this variable on partner expertise is therefore not directly obvious. ${ }^{13}$

Client business risk is influenced by the profitability, liquidity and solvability of a client (e.g. Simunic and Stein 1996; Johnstone 2000; Francis and 
Reynolds 2001). This study uses two measures of profitability, a measure of liquidity and a measure of solvability to proxy for client business risk. The Return on Assets (ROA) and the Net Profit Margin (NPM) are both measures of client profitability. ROA is calculated as net income divided by total assets. NPM is calculated as net income divided by sales. Higher values for these variables are associated with lower client business risk and can therefore be expected to be negatively associated with partner expertise.

Client financial distress is a common reason for litigation against the auditor (St. Pierre and Anderson 1984; Palmrose 1987). Companies with a low liquidity face a higher risk of short term insolvency and therefore a higher risk of financial distress (Francis and Reynolds 2001). The quick ratio (QUICK) is a measure of liquidity and is computed as the ratio of current assets (minus inventory) to current liabilities. A quick ratio lower than 1 is usually perceived as an indicator of increased client business risk. A negative association between QUICK and partner expertise is expected because a lower quick ratio indicates a higher client business risk.

Leverage (LEV) is an objective measure of solvability and bankruptcy risk, and has been commonly used in auditing research (e.g. Simunic and Stein 1996). LEV is computed as the ratio of total debt to total assets. Companies that have a higher leverage pose higher client business risk. This variable is therefore expected to be positively associated with partner expertise.

Audit firms consider a public listing to be an important driver of auditor business risk (Bell et al. 2002; Johnstone and Bedard 2003). Companies that are listed on a stock exchange receive more media attention, and therefore present a greater possible reputation loss in case of material misstatements that were not detected by the auditor. The risk of litigation and the damage awards are also greater for clients with a stock listing (St. Pierre and Anderson 1984; Lys and Watts 1994). The variable LISTED is set to equal 1 if the company is listed on the Belgian stock exchange, 0 otherwise. A positive relationship between auditor business risk and partner expertise is expected.

\subsubsection{Control variables}

A number of control variables are included based on prior literature (e.g. Simunic 1984; Reynolds and Francis 2001; Vander Bauwhede and Willekens 2004). ${ }^{14}$

The first control variable, WORKS_COUNCIL, indicates whether a company is required to have a works council. Belgian companies that have more than 100 employees are required to submit economic and financial information to a works council, and auditors are obliged to explain this information to the works council. According to Lefevbre et al. (1995) employees are important users of the financial statements in companies with a work council. Relations with banks, trade creditors and employees can create incentives for management to manage earnings upwards, but they may also constrain earnings management (Sercu et al. 2002). The relationship between the presence of a works council and the level of expertise of the allocated partner is not directly clear because on the one hand it is related to an increased 
focus on the auditor's work, whereas on the other hand it serves as an additional monitoring mechanism on which the auditor can rely.

Next, a number of proxies for complexity are included. More complex clients are likely to benefit more from a partner with a higher level of expertise. Two common measures used to proxy for complexity are the number of subsidiaries, and the number of industries in which the client operates ( $\mathrm{Si}$ munic 1984). NUM_SUBS is the number of subsidiaries in which the company has a more than 50 percent interest. NUM_INDS is measured as the number of two-digit NACE industry groups in which the company operates. A positive relationship between these variables and the expertise of the allocated audit partner is expected.

Furthermore, two measures of client size, the natural log of total assets (TOTAL_ASSETS) and the natural log of revenues (REVENUES) are included. Client size is positively related to the amount of audit fees (e.g. Simunic 1980), making larger clients potentially more interesting for audit partners. Hence, a positive effect of the size related measures on the general experience of the allocated partner is expected.

The final control variable, BIGN, indicates whether a company is audited by a Big $N$ audit firm (1), or a non-Big $N$ audit firm (0). Big $N$ audit firms differ from non-Big $\mathrm{N}$ audit firms in various aspects. A main difference is that Big $\mathrm{N}$ audit firms are larger, which allows their audit partners to specialize more than auditors working for non-Big $\mathrm{N}$ audit firms. It is therefore more likely that partner expertise is used as a risk management strategy by Big $\mathrm{N}$ clients.

\subsection{Results}

This section presents some descriptive statistics, followed by a factor analysis aimed at reducing the large number of variables that are used as proxies for risk. Subsequently, the regression models are presented, and finally the results of the regressions.

\subsubsection{Descriptive statistics}

For reasons explained in section 2.3, the sample of 2,554 observations is used for the analyses. This section first provides some general descriptive statistics for the Belgian market for audit services. These descriptive statistics are based on the more complete sample of 74,730 observations to give a more accurate overview of the Belgian market for audit services. Appendix $C$ provides an overview of the number of observations per two-digit NACE industry group.

The 74,730 observations (14,592 unique companies) are audited by 483 different audit firms and 900 different partners. Panels A and B of Table 2.2 provide some insight into the market shares of the Belgian audit firms for the sample examined in the current study. The market share of the Big $\mathrm{N}$ audit firms adds up to 48 percent when measured based on the number of conducted audits. ${ }^{15}$ The portion of assets audited by Big $\mathrm{N}$ audit firms equals 
Table 2.2 - Panel A: Audit firm market shares based on the number of clients for the largest 10 audit firms $(\mathrm{n}=74,730)$

\begin{tabular}{lcc} 
Audit firm name & Number of clients & Percentage Market \\
\cline { 2 - 3 } 1. Ernst \& Young & 10,226 & $13.68 \%$ \\
2. PricewaterhouseCoopers & 8,858 & $11.85 \%$ \\
3. Deloitte \& Touche & 7,865 & $10.52 \%$ \\
4. Klynveld Peat Marwick Goerdeler & 7,073 & $9.46 \%$ \\
5. BDO Atrio & 2,128 & $2.85 \%$ \\
6. Arthur Andersen & 1,619 & $2.17 \%$ \\
7. Grant Thornton, Lippens, Rabaey \& Co & 1,292 & $1.73 \%$ \\
8. TCLM - Toelen, Cats & 1,051 & $1.41 \%$ \\
9. Van Passel, Mazars \& Guerard & 1,014 & $1.36 \%$ \\
10. Hermant, Dodemont \& Co & 957 & $1.28 \%$ \\
Full Sample (483 audit firms) & 74,730 & $100.00 \%$ \\
\hline
\end{tabular}

Table 2.2 - Panel B: Audit firm market shares based on audited assets (in billions of euros) for the largest 10 audit firms $(n=74,730)$

\begin{tabular}{|c|c|c|c|}
\hline & & $\frac{\text { Percentage market }}{\text { share based on }}$ & $\frac{\text { Percentage market }}{\text { share based on the }}$ \\
\hline Audit firm name & Audited assets & assets & natural log of assets \\
\hline PricewaterhouseCoopers & 667.24 & $22.88 \%$ & $13.66 \%$ \\
\hline Ernst \& Young & 542.02 & $18.58 \%$ & $12.16 \%$ \\
\hline Klynveld Peat Marwick Goerdeler & 531.86 & $18.24 \%$ & $10.71 \%$ \\
\hline Deloitte \& Touche & 486.25 & $16.67 \%$ & $9.69 \%$ \\
\hline Arthur Andersen & 88.65 & $3.04 \%$ & $2.80 \%$ \\
\hline Van Passel, Mazars \& Guerard & 33.47 & $1.15 \%$ & $2.22 \%$ \\
\hline BDO Atrio & 33.09 & $1.13 \%$ & $1.75 \%$ \\
\hline Grant Thorton, Lippens, Rabaey \& Co & 26.22 & $0.90 \%$ & $1.39 \%$ \\
\hline TCLM - Toelen, Cats & 24.45 & $0.84 \%$ & $1.30 \%$ \\
\hline Callens, Guevar, Van Impe \& Co & 22.26 & $0.76 \%$ & $1.22 \%$ \\
\hline Full Sample (483 audit firms) & $2,916.69$ & $100.00 \%$ & $100.00 \%$ \\
\hline
\end{tabular}

79 percent, however this percentage is likely to be overstated because prior literature found that there is a non-linear relationship between client size and audit fees (Simunic 1980). The market shares based on the natural logarithms of client assets are more in line with those of Panel A of Table 2.2, indicating a market share of 49 percent for the Big $\mathrm{N}$ audit firms. The percentage of clients audited by Big $\mathrm{N}$ audit firms is lower than what is usually reported in studies that examine only listed companies, where the Big $\mathrm{N}$ audit firms have a more dominant market share.

Table 2.3 provides both the number of clients per audit firm and the number of clients per audit partner. The average number of clients per audit partner for the Big $\mathrm{N}$ firms ranges from 17.28 to 19.06 , while it ranges from 10.22 to 12.27 clients per partner per year for the non-Big N firms. The average number of clients for sole proprietorships is even smaller, ranging from 6.69 to 7.49. The average number of clients per audit firm is also greater for Big $\mathrm{N}$ audit firms than for non-Big $\mathrm{N}$ audit firms. All differences are significant at the 1 percent level. Apart from confirming that Big $\mathrm{N}$ audit firms are in general larger than non-Big $\mathrm{N}$ audit firms, Table 2.3 also shows that partners working for Big $\mathrm{N}$ audit firms audit more clients than partners working for 
Table 2.3: Average number of clients per firm and per partner for Big $\mathrm{N}$ firms, non-Big $\mathrm{N}$ firms and sole proprietorships $(\mathrm{n}=74,730)$

\begin{tabular}{l|cc|cc|c|} 
& \multicolumn{2}{|c|}{ BIG N } & \multicolumn{2}{c|}{ Non-BIG $N$} & Sole proprietorships \\
$\frac{\text { Year }}{1998}$ & $\frac{\text { Avg. number of }}{\frac{\text { clients per }}{\text { partner }}}$ & $\frac{\text { Avg. number of }}{\text { clients per firm }}$ & $\frac{\text { Avg. number of }}{\frac{\text { clients per }}{\text { partner }}}$ & $\frac{\text { Avg. number }}{\text { of clients per }}$ & Avg. number of clients \\
1999 & 17.53 & $\frac{694.40}{11.91}$ & $\frac{\text { firm }}{37.36}$ & $\frac{\text { per firm }}{7.18}$ \\
2000 & 18.24 & 744.20 & 12.27 & 40.50 & 6.98 \\
2001 & 18.52 & 785.40 & 10.85 & 36.93 & 7.44 \\
2002 & 17.95 & 836.60 & 10.91 & 36.68 & 7.10 \\
2003 & 17.28 & $1,045.25$ & 10.22 & 34.16 & 7.49 \\
2004 & 17.71 & $1,027.25$ & 10.24 & 34.59 & 7.24 \\
2005 & 19.06 & $1,019.50$ & 10.62 & 36.33 & 6.69 \\
2006 & 18.51 & $1,013.50$ & 10.92 & 37.12 & 6.96 \\
& 18.21 & 979.00 & 10.87 & 38.58 & 7.42
\end{tabular}

Sole proprietorships are audit firms with only one audit partner. Therefore no separate column for the number of partners is shown for sole proprietorships, since the number of audit firms equals the number of audit partners for these firms.

Table 2.4: Number of audit firms and partners per year and their average experience in years for Big N firms, non-Big N firms and Sole proprietorships ( $\mathrm{n}=74,730)$

\begin{tabular}{|c|c|c|c|c|c|c|c|c|}
\hline \multirow[b]{2}{*}{ Year } & \multirow[b]{2}{*}{$\frac{\text { Number of }}{\text { partners }}$} & \multirow{2}{*}{$\begin{array}{l}\text { BIG } N \\
\text { Number } \\
\underline{\text { of audit }} \\
\underline{\text { firms }}\end{array}$} & \multirow{2}{*}{$\frac{\frac{\text { Avg. }}{\text { Exp. In }}}{\text { years }}$} & \multicolumn{3}{|c|}{ Non-BIG N } & \multicolumn{2}{|c|}{$\begin{array}{l}\text { Sole Proprietorships } \\
\text { Number of }\end{array}$} \\
\hline & & & & $\overline{\text { of audit }}$ & $\frac{\text { of audit }}{\text { firms }}$ & $\frac{\text { Avg. }}{\text { Exp. }}$ & $\underline{\underline{\text { audit }}}$ & $\frac{\text { Avg. }}{\text { Exp. }}$ \\
\hline$\overline{1998}$ & 198 & $\overline{5}$ & 13.22 & 254 & $\overline{81}$ & $\overline{13.49}$ & $\overline{190}$ & $\overline{13.67}$ \\
\hline 1999 & 204 & 5 & 13.65 & 231 & 70 & 13.65 & 209 & 14.06 \\
\hline 2000 & 212 & 5 & 13.65 & 245 & 72 & 14.36 & 213 & 14.74 \\
\hline 2001 & 233 & 5 & 13.87 & 242 & 72 & 15.10 & 216 & 14.93 \\
\hline 2002 & 242 & 4 & 14.78 & 254 & 76 & 15.85 & 203 & 15.70 \\
\hline 2003 & 232 & 4 & 14.96 & 267 & 79 & 16.47 & 208 & 16.46 \\
\hline 2004 & 214 & 4 & 15.57 & 284 & 83 & 16.92 & 210 & 16.90 \\
\hline 2005 & 219 & 4 & 15.52 & 289 & 85 & 17.46 & 206 & 17.31 \\
\hline 2006 & 215 & 4 & 15.87 & 284 & 80 & 17.94 & 207 & 17.88 \\
\hline
\end{tabular}

non-Big $\mathrm{N}$ audit firms. A possible explanation is that Big $\mathrm{N}$ audit firms have more support staff available than non-Big $\mathrm{N}$ audit firms, allowing partners of Big $\mathrm{N}$ audit firms to audit more clients than partners of non-Big $\mathrm{N}$ audit firms.

Table 2.4 displays the general experience, measured as the number of years of experience as an auditor, for all of the partners included in the sample of 74,730 observations. The general experience per partner for Big N firms is on average lower than for sole proprietorships and other non-Big $\mathrm{N}$ audit firms. Differences are statistically significant at the 1 percent level.

The remaining analyses use the sample of 2,554 observations for which the audit partner changed while the client remained to be audited by the same audit firm. Table 2.5 provides the descriptive statistics for this reduced sample for the variables that were discussed in the previous section. ${ }^{16}$ As auditor allocation takes place at the beginning of the fiscal year, the allocation decision can be expected to be based on the audited financial statements for the previous year. ${ }^{17}$ For this reason, financial information from the previous year is used to explain partner allocation in the year under examination. 
Table 2.5 - Descriptive statistics for the estimation samples for Big $\mathrm{N}$ clients, Non-Big $\mathrm{N}$ clients and all clients

\begin{tabular}{|c|c|c|c|}
\hline Variables & Big N clients & Non-Big N clients & All clients \\
\hline$\overline{\text { IRTA }_{t-1}}$ & $.542(0.287)$ & $.516(0.267)$ &.$\overline{399(0.285)}$ \\
\hline CATA $_{t-1}$ & $.698(0.291)$ & $.672(0.277)$ & $.695(0.290)$ \\
\hline TURN $_{\mathrm{t}-1}$ & $1.735(1.456)$ & $1.821(1.544)$ & $1.745(1.467)$ \\
\hline QUICK $_{\mathrm{t}-1}$ & $2.028(3.719)$ & $1.785(3.301)$ & $1.998(3.670)$ \\
\hline $\mathrm{LEV}_{\mathrm{t}-1}$ & $.655(0.260)$ & $.644(0.247)$ & $.654(0.259)$ \\
\hline $\mathrm{NPM}_{\mathrm{t}-1}$ & $.060(0.462)$ & $.048(0.379)$ & $.059(0.452)$ \\
\hline $\mathrm{ROA}_{\mathrm{t}-1}$ & $.024(0.124)$ & $.027(0.095)$ & $.024(0.121)$ \\
\hline $\mathrm{TA}_{\mathrm{t}-1}$ & $39.209(100.642)$ & $14.932(48.326)$ & $36.244(96.118)$ \\
\hline$R E V_{t-1}$ & $36.052(79.242)$ & $17.074(37.950)$ & $33.733(75.671)$ \\
\hline WORKS_COUNCIL t-1 & $.216(.412)$ & $.119(.324)$ & $.204(.403)$ \\
\hline LISTED $_{\mathrm{t}-1}$ & $.007(.082)$ & $.003(.057)$ & $.006(.079)$ \\
\hline NUM_INDS ${ }_{t-1}$ & $1.707(0.929)$ & $1.625(0.902)$ & $1.697(0.926)$ \\
\hline NUM_SUBS ${ }_{t-1}$ & $.750(1.818)$ & $.728(1.612)$ & $.747(1.794)$ \\
\hline GENERAL_EXPERIENCE $_{t}$ & $11.444(6.065)$ & $10.715(6.560)$ & $11.355(6.131)$ \\
\hline INDUSTRY_EXPERIENCE $_{i, \mathrm{t}}$ & $.141(0.184)$ & $.111(0.171)$ & $.138(0.183)$ \\
\hline \multicolumn{4}{|c|}{$\begin{array}{l}\text {-The numbers before the brackets denotes the mean. The numbers between brackets denote the standard deviation. } \\
\text {-All variables have been winsorized at the top and bottom } 1 \text { percent. }\end{array}$} \\
\hline $\mathrm{IRTA}_{\mathrm{t}-1}$ & \multirow{4}{*}{\multicolumn{3}{|c|}{$\begin{array}{l}\text { Receivables in year } \mathrm{t}-1 \text { plus inventory in year } \mathrm{t}-1 \text { scaled by total assets in year } \mathrm{t}-1 \text {. } \\
\text { Current assets in year } \mathrm{t}-1 \text { scaled by total assets in year } \mathrm{t}-1 \text {. } \\
\text { Asset turnover in year } \mathrm{t}-1 \text {, defined as the ratio of sales to total assets. } \\
\text { Quick ratio in year } \mathrm{t}-1 \text {, defined as the ratio of current assets minus inventory to current } \\
\text { liabilities. }\end{array}$}} \\
\hline CATA $_{t-1}$ & & & \\
\hline TURN $_{\mathrm{t}-1}$ & & & \\
\hline QUICK $_{\mathrm{t}-1}$ & & & \\
\hline $\mathrm{LEV}_{\mathrm{t}-1}$ & \multicolumn{3}{|c|}{ Leverage in year $\mathrm{t}-1$, defined as the ratio total debt to total assets. } \\
\hline $\mathrm{NPM}_{\mathrm{t}-1}$ & \multicolumn{3}{|c|}{ Net profit margin for year $\mathrm{t}-1$, calculated as net income divided by sales. } \\
\hline $\mathrm{ROA}_{\mathrm{t}-1}$ & \multicolumn{3}{|c|}{ Return on assets for year $\mathrm{t}-1$, calculated as profit divided by total assets. } \\
\hline TOTAL_ASSETS $\mathrm{t}_{-1}$ & \multicolumn{3}{|c|}{ Total assets in year t-1 stated in thousands of Euros. } \\
\hline REVENUES $S_{t-1}$ & \multicolumn{3}{|c|}{ Revenues in year $\mathrm{t}-1$ stated in thousands of Euros } \\
\hline WORKS_COUNCIL & \multicolumn{3}{|c|}{$\begin{array}{l}\text { Dummy variable indicating } 1 \text { if the company had more than } 100 \text { employees in year } t-1,0 \\
\text { otherwise. }\end{array}$} \\
\hline LISTED $_{\mathrm{t}-1}$ & \multicolumn{3}{|c|}{$\begin{array}{l}\text { Dummy variable, indicating } 1 \text { if the company is listed on the Belgian stock exchange in } \\
\text { year } t-1,0 \text { otherwise. }\end{array}$} \\
\hline NUM_INDS $\mathrm{t}_{\mathrm{t}-1}$ & \multicolumn{3}{|c|}{$\begin{array}{l}\text { Number of industries in which the company operates in year } t-1 \text {, measured as the } \\
\text { number of 2-digit NACE industry codes. }\end{array}$} \\
\hline NUM_SUBS $t_{t-1}$ & \multicolumn{3}{|c|}{$\begin{array}{l}\text { Number of subsidiaries in which the company holds a greater than } 50 \text { percent interest in } \\
\text { year } t-1 \text {. }\end{array}$} \\
\hline GENERAL_EXPERIENCE $\mathrm{t}_{\mathrm{t}}$ & \multirow{2}{*}{\multicolumn{3}{|c|}{$\begin{array}{l}\text { Number of years since the auditor obtained his CPA title in year } t \text {. } \\
\text { Measure of partner industry experience in year } t \text {, computed as the sum of the natural log } \\
\text { of total assets from clients audited by a partner within industry } i \text { in year } t-1 \text {, scaled by the } \\
\text { sum of the natural log of total assets from all clients audited by that partner in year } t-1 \text {. }\end{array}$}} \\
\hline INDUSTRȲ_EXPERIENCE $E_{i, t}$ & & & \\
\hline
\end{tabular}

Less than 1 percent of the observations included in the sample have a stock exchange listing. The general partner experience for the Big $\mathrm{N}$ sample is higher than for the non-Big N sample (difference significant at the 5 percent level). These results differ from those reported in Table 2.4 which showed that audit partners of Big $\mathrm{N}$ audit firms have less experience than audit partners of non-Big $\mathrm{N}$ audit firms. Further analysis shows that partners of Big $\mathrm{N}$ firms with more years of experience audit more clients than partners with less experience, suggesting that partners start with a small portfolio of clients, which increases as they get more years of experience. Partners of Big $\mathrm{N}$ audit firms also have a higher industry experience than partners of non-Big $\mathrm{N}$ audit firms (difference significant at the 1 percent level). This is consistent with the expectation stated in section 2.3.4.3 that audit partners working for Big $\mathrm{N}$ audit firms are more likely to be able to specialize into specific industries than audit partners working for non-Big $\mathrm{N}$ audit firms. 


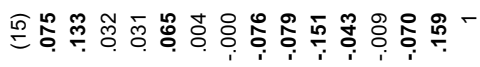

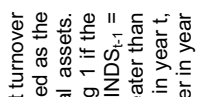

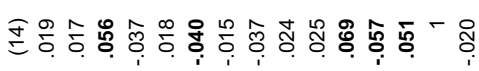

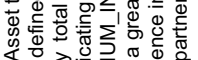

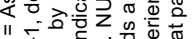

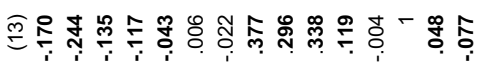

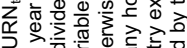

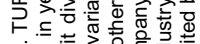

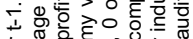

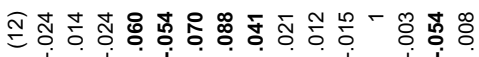

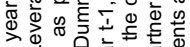
.

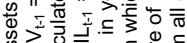

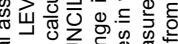

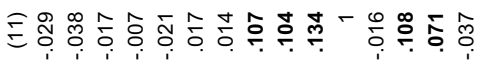

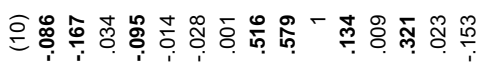

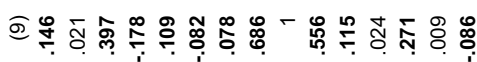

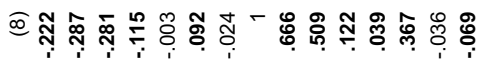

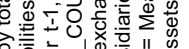

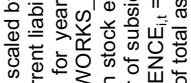
年

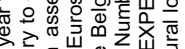

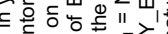

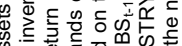

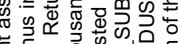
बํ.

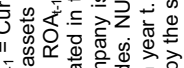
过芯的需

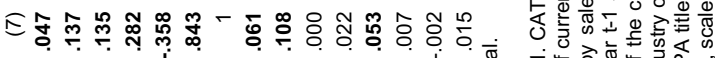

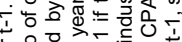

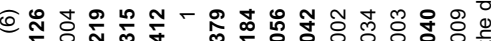

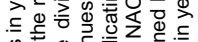

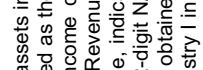

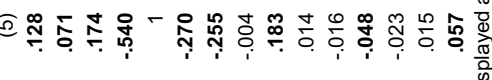

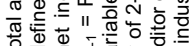

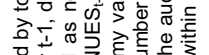

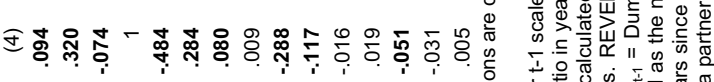

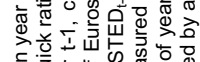

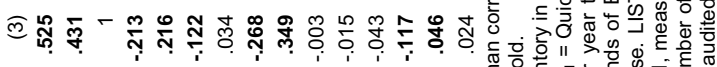

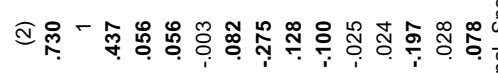

.

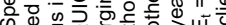

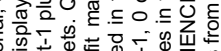

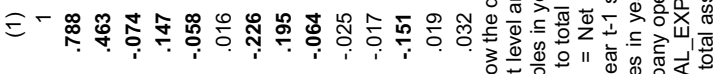

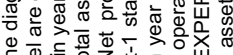

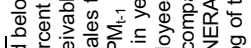

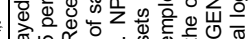

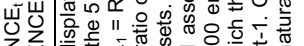

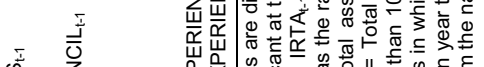

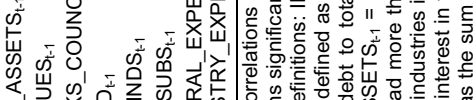

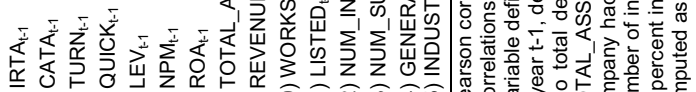

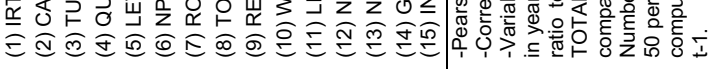


Table 2.7 - Summary of common factor analysis $(n=2,554)$

\section{Factor Loadings}

\begin{tabular}{|c|c|c|c|}
\hline & Factor 1 & Factor 2 & Factor 3 \\
\hline Cronbach's Alpha & .794 & .799 & .622 \\
\hline IRTA $_{t-1}$ & .828 & -.056 & .046 \\
\hline $\mathrm{CATA}_{\mathrm{t}-1}$ & .849 & -.116 & .184 \\
\hline TURN $_{\mathrm{t}-1}$ & .635 & .026 & -.191 \\
\hline QUICK $_{t-1}$ & -.022 & -.147 & .587 \\
\hline $\mathrm{LEV}_{\mathrm{t}-1}$ & .069 & .061 & -.581 \\
\hline $\mathrm{NPM}_{\mathrm{t}-1}$ & .037 & .124 & .570 \\
\hline $\mathrm{ROA}_{\mathrm{t}-1}$ & .162 & .150 & .443 \\
\hline LN(TOTAL_ASSETS $\left.\mathrm{t}_{\mathrm{t}-1}\right)$ & -.252 & .867 & .175 \\
\hline LN(REVENUES $\left.{ }_{t-1}\right)$ & .295 & .856 & -.084 \\
\hline LN(NUM_SUBS t-1 $\left._{\text {- }}\right)$ & -.186 & .369 & -.004 \\
\hline LN(NUM_INDS t-1 $\left._{\text {- }}\right)$ & .000 & .032 & .049 \\
\hline \multicolumn{4}{|c|}{$\begin{array}{l}\text {-Factors loadings above } .400 \text { are displayed in bold. } \\
\text {-FACTOR } 1 \text { is labeled AUDIT_RISK }{ }_{\mathrm{t}-1} \\
\text {-FACTOR } 2 \text { is labeled SIZE-1- } \\
\text {-FACTOR } 3 \text { is labeled CLIENT_BUSINESS_RISK }{ }^{\mathrm{t}-1} \\
\text {-Variable definitions: }\end{array}$} \\
\hline IRTA $A_{t-1}$ & \multirow{3}{*}{\multicolumn{3}{|c|}{$\begin{array}{l}\text { Receivables in year } \mathrm{t}-1 \text { plus inventory in year } \mathrm{t}-1 \text { scaled by total assets in year } \mathrm{t}-1 \text {. } \\
\text { Current assets in year } \mathrm{t}-1 \text { scaled by total assets in year } \mathrm{t}-1 \text {. } \\
\text { Asset turnover in year } \mathrm{t}-1 \text {, defined as the ratio of sales to total assets. } \\
\text { Quick ratio in year } \mathrm{t}-1 \text {, defined as the ratio of current assets minus inventory to current } \\
\text { liabilities. }\end{array}$}} \\
\hline $\begin{array}{l}\text { CAIA } A_{t-1} \\
\text { TURN }_{t-1}\end{array}$ & & & \\
\hline QUICK $_{t-1}$ & & & \\
\hline $\mathrm{LEV}_{\mathrm{t}-1}$ & \multicolumn{3}{|c|}{ Leverage in year $\mathrm{t}-1$, defined as the ratio total debt to total assets. } \\
\hline $\mathrm{NPM}_{\mathrm{t}-1}$ & \multicolumn{3}{|c|}{ Net profit margin for year $\mathrm{t}-1$, calculated as net income divided by sales. } \\
\hline $\mathrm{ROA}_{\mathrm{t}-1}$ & \multicolumn{3}{|c|}{ Return on assets for year $\mathrm{t}-1$, calculated profit divided by total assets. } \\
\hline LN(TOTAL_ASSETS ${ }_{\mathrm{t}-1}$ ) & \multicolumn{3}{|c|}{$\begin{array}{l}\text { Natural log of total assets in year t-1 stated in thousands of Euros, corrected for inflation using } \\
\text { the GDP price deflator. }\end{array}$} \\
\hline LN(REVENUES $\mathrm{t}-1)$ & \multicolumn{3}{|c|}{$\begin{array}{l}\text { Natural log of revenues in year t- } 1 \text { stated in thousands of Euros, corrected for inflation using } \\
\text { the GDP price deflator. }\end{array}$} \\
\hline LN(NUM_INDS $\left.\mathrm{t}_{\mathrm{t}-1}\right)$ & \multicolumn{3}{|c|}{$\begin{array}{l}\text { Natural log of the number of industries in which the company operates in year t-1, measured } \\
\text { as the number of 2-digit NACE industry codes. }\end{array}$} \\
\hline LN(NUM_SUBS $\left.{ }_{t-1}\right)$ & \multicolumn{3}{|c|}{$\begin{array}{l}\text { Natural log of the number of subsidiaries in which the company holds a more than } 50 \text { percent } \\
\text { interest in year } t-1 \text {. }\end{array}$} \\
\hline
\end{tabular}

\subsubsection{Factor analysis}

Many of the independent variables are significantly correlated (see Table 2.6). Factor analysis is used to reduce the number of variables by summarizing them into a smaller set of factors. Factor analysis is applied to the 11 continuous variables, also shown in Table 2.7. ${ }^{18}$ The selected variables are similar to those described in Table 2.5, with the exception that the natural logarithms of the following variables are used to control for heteroscedasticity between the dependent variable and the independent variables: TOTAL_ASSETS ${ }_{t-1}$, REVENUES $_{t-1}$, NUM_SUBS $_{t-1}$, and NUM_INDS ${ }_{t-1}$. The variables TOTAL_ASSETS ${ }_{t-1}$ and REVENUES t $_{t-1}$ are from this point onwards corrected for inflation using the GDP price deflator to improve comparability across the years.

Because the goal of this factor analysis is to identify the latent constructs by creating a small number of factors to account for the intercorrelations among the observed variables, this study uses common factor analysis instead of component factor analysis. ${ }^{19}$ Common factor analysis takes only the common variance of the variables into account, whereas component factor analysis takes both the common and the unique variance of variables into account. Common factor analysis is more appropriate since it does not require the error and specific variance to represent a small portion of the total variance (Hair et al. 2006). 
A three factor solution is used, which follows from the root criterion, ${ }^{20}$ the proportion criterion, and the scree plot. After applying an oblique factor rotation on the standardized variables, the factor loadings as shown in table 2.7 are obtained.

Factor 1 loads on two audit risk related factors IRTA $\mathrm{I}_{\mathrm{t}-1}$ and CATA $\mathrm{A}_{\mathrm{t}-1}$, and on TURN $\mathrm{t}_{\mathrm{t}-1}$ and will therefore be labeled AUDIT_RISK $\mathrm{t}_{\mathrm{t}-1}$. Factor 2 loads on two size variables (the natural $\log$ of TOTAL_ASSETS $\mathrm{t}_{\mathrm{t}-1}$, and the natural log of REVENUES $\mathrm{S}_{\mathrm{t}-1}$ ), and will therefore be labeled $\mathrm{SIZE}_{\mathrm{t}-1}$. Factor 3 loads on two profitability measures $\left(\mathrm{ROA}_{\mathrm{t}-1}\right.$ and $\left.\mathrm{NPM}_{\mathrm{t}-1}\right)$, and two debt variables $\left(\right.$ QUICK $_{\mathrm{t}-1}$ and $\left.\mathrm{LEV}_{\mathrm{t}-1}\right)$. These variables are all measures of client financial health, and therefore this variable will be labeled CLIENT_BUSINESS $\mathrm{RISK}_{\mathrm{t}-1}$. The variables that have a loading below .40 are not included in the further analyses.

\subsubsection{Regressions}

Ordinary least squares regressions are used to test the hypotheses. The measures AUDIT_RISK $\mathrm{t}_{\mathrm{t}-1}$ and CLIENT_BUSINESS_RISK $\mathrm{t}_{\mathrm{t}-1}$ follow from the factor analysis discussed in the previous paragraph. ${ }^{23}$ Both these variables are measured in such a way that a higher value indicates a higher risk. Therefore, in line with the hypotheses, a negative relation between AUDIT_RISK ${ }_{\mathrm{t}-1}$ and CLIENT_BUSINESS_RISK $\mathrm{t}_{\mathrm{t}-1}$ and the expertise measures is expected. A stock exchange listing is used to proxy for auditor business risk, AUDITOR_BUSINESS_RISK $\mathrm{t}_{\mathrm{t}-1}$, for which a positive relationship with the expertise measures is expected. In addition, as discussed in section 2.3, WORKS_COUNCIL $\mathrm{t}_{\mathrm{t}-1}, \mathrm{SIZE}_{\mathrm{t}-1}$, and $\mathrm{BIGN}_{\mathrm{t}}$ are included as control variables. Furthermore, dummy variables are included to control for possible fiscal year effects.

For each fiscal year, the dependent variable and the continuous independent variables are group mean centered, with audit firms as the grouping variable. This way it is possible to examine whether an audit firm allocates a partner with relatively higher (lower) expertise to a client that poses relatively higher (lower) risk. Mean centering per audit firm is required for the regression analysis to reflect that audit firms can only allocate their own audit partners, and not audit partners working for other audit firms. The definitions for the restated variables are provided in Table 2.8 , as well as in subsequent tables.

To test whether more experienced auditors are allocated to clients with respectively a higher audit risk, a higher client business risk and a higher audit business risk, a regression is estimated in which the relative general experience of the audit partner is tested as a function of the aforementioned risk and control variables, as described in the following model:

$$
\begin{aligned}
& \text { REL_GENERAL_EXPERIENCE } E_{t}=\beta_{0}+\beta_{1} R E L_{-} A U D I T T_{-} R I S K_{t-1}+ \\
& \beta_{2} R E L \_C L I E N T \_B U S I N E S S_{-} R I S K_{t-1}+ \\
& \beta_{3} \text { AUDITOR_BUSINESS_RISK } K_{t-1}+\beta_{4} R E L_{-} S I Z E_{t-1}+ \\
& \beta_{5} \text { WORKS_COUNCIL }_{t-1}+\beta_{6} \text { BIGN }_{t}+\sum_{7}^{13} \beta_{i} \text { YEAR_DUMMIES }+\varepsilon
\end{aligned}
$$


where:

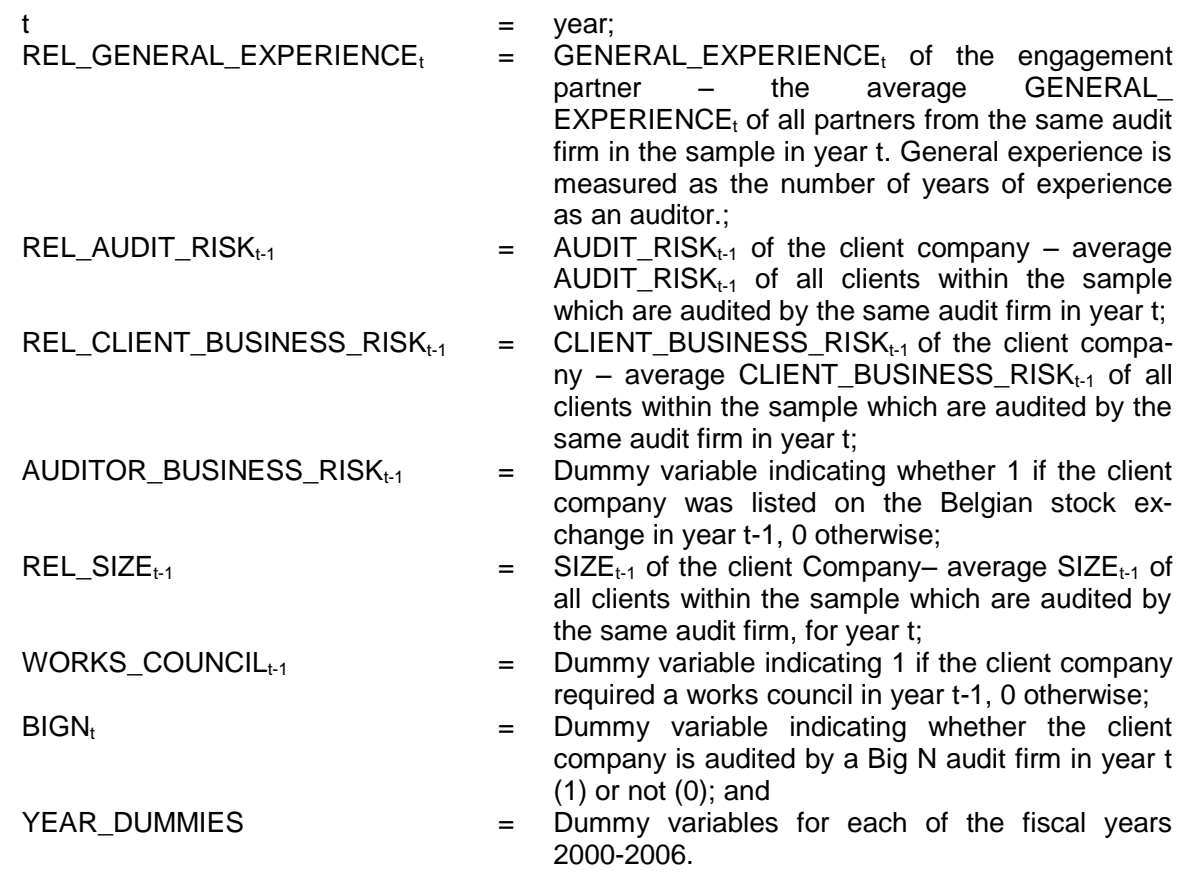

Similarly, to examine whether audit partners with greater industry experience are allocated to clients with respectively a higher audit risk, a higher client business risk and a higher audit business risk, a regression is estimated in which the relative industry experience of the audit partner is regressed on the risk variables and control variables, as reflected in the following model:

$$
\begin{aligned}
& \text { REL_INDUSTRY_EXPERIENCE } E_{t}=\beta_{0}+\beta_{1} R E L_{-} A U D I T_{-} R I S K_{t-1}+ \\
& \beta_{2} R E L_{-} C L I E N T \_B U S I N E S S_{-} R I S K_{t-1}+ \\
& \beta_{3} \text { AUDITOR_BUSINESS_RISK } K_{t-1}+\beta_{4} R E L_{-} S I Z E_{t-1}+ \\
& \beta_{5} \text { WORKS_COUNCIL } L_{t-1}+\beta_{6} B I G N_{t}+\sum_{7}^{13} \beta_{i} Y E A R \_D U M M I E S+\varepsilon
\end{aligned}
$$

where:

REL_INDUSTRY_EXPERIENCE ${ }_{t}=$ INDUSTRY_EXPERIENCE $E_{i, t}$ of the engagement partner - the average INDUSTRY EXPERIENCE $E_{i, t}$ of all partners from the same audit firm in the sample in year $t$.

The remaining variables are defined as earlier.

\subsubsection{Test of hypotheses}

Ordinary least squares regressions with robust standard errors are estimated to test the previously stated hypotheses. The sample includes multiple observations per audit firm per year. The assumption that observations 
are independent is therefore violated. To overcome this issue, robust standard errors are computed to allow observations to be correlated within clusters of the same audit firm. To estimate whether audit firms allocate partners with greater expertise to relatively riskier clients, all the explanatory variables have been group mean centered, for each audit firm, per fiscal year.

Table 2.8 shows the results for hypotheses 1,2 and 3 . Panel A shows the results for general partner experience as the dependent variable, panel $B$ shows the results for partner industry experience as the dependent variable. Results are reported for 3 different samples: (1) a sample which includes only clients of Big N audit firms, (2) a sample that includes only clients of non-Big $\mathrm{N}$ audit firms, and (3) the full sample, which includes clients from both Big $\mathrm{N}$ firms and non-Big $\mathrm{N}$ firms. This makes it possible to observe possible differences in the use of partner expertise between Big $\mathrm{N}$ and nonBig $\mathrm{N}$ audit firms. The adjusted R-square equals 1.13 percent for the full sample, and 1.50 percent for the sample consisting of Big $\mathrm{N}$ clients. The regression for the clients of non-Big $\mathrm{N}$ audit firms has a negative adjusted $\mathrm{R}$ square $\left(-0.60\right.$ percent) ${ }^{24}$ This indicates that some of the explanatory variables may add no value to this model. The highest variance inflation factor (VIF) equals 2.02, indicating that multicollinearity is not a cause for concern. Year dummies are not reported for the sake of brevity.

The results for the full sample show that the coefficient for the REL_AUDIT_RISK $\mathrm{t}_{\mathrm{t}-1}$ is in the expected direction, but insignificant at conventional levels $(\beta=.059, p>.10)$. Analysis of the subsamples shows that the coefficient for REL_AUDIT_RISK $\mathrm{t}_{\mathrm{t}-1}$ is insignificant for the sample of Big N clients $(\beta=-.015, p>.10)$, but positive and significant for the sample of NonBig $N$ clients $(\beta=.828, p<.10)$. This indicates that there is only limited support for hypothesis 1 , which states that audit firms allocate partners with more expertise to clients that pose higher audit risk. General audit partner experience seems to be used to manage audit risk, but only by non-Big $\mathrm{N}$ audit firms.

The coefficient for the variable REL_CLIENT_BUSINESS_RISK $\mathrm{t}_{\mathrm{t}-1}$ is insignificant for each of the three samples, and thus provides insufficient evidence to accept hypothesis 2, which states that audit firms allocate partners with greater expertise to clients that pose higher client business risk. A possible explanation for this finding is that the issuance of going concern opinions is rules-based in Belgium, leaving limited room for auditor judgment (e.g. Carcello et al. 2010).

Hypothesis 3 is tested using the variable AUDITOR_BUSINESS_RISK $\mathrm{t}_{\mathrm{t}-1}$. The coefficient of this variable is positive and significant for the full sample $(\beta=4.674, p<.01)$, as well as both subsamples. The coefficient equals 4.778 $(p<.01)$ for the Big N sample and $2.566(p<.05)$ for the non-Big N sample. This means that listed clients of Big N (non-Big N) audit firms are, on average, audited by a partner with approximately 5 years (2.5 years) more experience than non listed clients. These results support the hypothesis that audit firms allocate partners with greater general experience to clients that pose a higher auditor business risk. However, it is possible that experienced auditors choose to audit listed companies because of prestige concerns and career development opportunities as opposed to risk management concerns. 
Table 2.8 - Panel A: OLS regressions with general audit partner experience as the dependent variable for the estimation samples of Big $\mathrm{N}$ clients, Non-Big $\mathrm{N}$ clients and all clients.

\begin{tabular}{|c|c|c|c|c|}
\hline \multirow[b]{4}{*}{ Variables } & \multirow[b]{4}{*}{ Exp. } & \multirow{3}{*}{$\underline{\text { Big N clients }}$} & \multirow{3}{*}{$\frac{\text { Non-Big N }}{\frac{\text { clients }}{n=312}}$} & \multirow{4}{*}{$\underline{\text { All clients }}$} \\
\hline & & & & \\
\hline & & & & \\
\hline & & & & \\
\hline & $\underline{\underline{\text { Sign }}}$ & Coefficients & Coefficients & Coefficients \\
\hline INTERCEPT & & $-.043(-.07)$ & $-1.749(-1.14)$ & $-.153(-.23)$ \\
\hline REL_AUDIT_RISK & + & $-.015(-.06)$ & $.828(1.85)^{\star}$ & $.059(.29)$ \\
\hline REL_CLIENT_BUSINESS_RISK ${ }_{\mathrm{t}-1}$ & + & $.059(.48)$ & $-.085(-.10)$ & $.051(.43)$ \\
\hline AUDITOR_BUSINESS_RISK $K_{t-1}$ & + & $4.778(5.75)^{\star \star \star}$ & $2.566(2.33)^{\star \star}$ & $4.674(6.45)^{\star \star \star}$ \\
\hline REL_SIZE & + & $-.069(-.28)$ & $-.411(-.58)$ & $-.091(-.43)$ \\
\hline WORKS_COUNCIL $L_{t-1}$ & $?$ & $.348(.76)$ & $1.082(.95)$ & $.426(1.08)$ \\
\hline $\mathrm{BIGN}_{\mathrm{t}}-$ & $?$ & -- & -- & $-.137(-.27)$ \\
\hline Adj. R-square & & .0150 & -.0060 & .0113 \\
\hline Model F-Value & & $28.19^{\star * *}$ & $203.01^{* \star *}$ & $435.12^{\star \star *}$ \\
\hline Highest VIF & & 2.02 & 2.00 & 1.97 \\
\hline \multicolumn{5}{|c|}{$\begin{array}{l}-{ }^{*},{ }^{* *},{ }^{* * *} \text { Significant at the } 10 \text { percent, } 5 \text { percent levels and } 1 \text { percent levels, respectively. } \\
- \text { The values before the brackets denote the coefficients. The values between brackets denote the t-values. } \\
- \text { All continuous variables are group mean centered, with audit firms as the grouping variable. } \\
\text { - Robust standard errors are used to account for possible correlated observations within clusters of the same audit firm. } \\
\text { - Coefficients for the year dummy variables are not reported for the sake of brevity. } \\
\text { - Variable definitions: }\end{array}$} \\
\hline REL_GENERAL_EXPERIENCE ${ }_{t}$ & \multicolumn{4}{|c|}{$\begin{array}{l}=\text { GENERAL_EXPERIENCE } E_{t} \text { of the engagement partner }- \text { the average } \\
\text { GENERAL_EXPERIENCE } E_{t} \text { of all partners from the same audit firm in the } \\
\text { sample in year } t \text {. }\end{array}$} \\
\hline REL_AUDIT_RISK $K_{t-1}$ & \multirow{2}{*}{\multicolumn{4}{|c|}{$\begin{array}{l}=\text { AUDIT_RISK } \mathrm{t}_{\mathrm{t}-1} \text { of the client company }- \text { average AUDIT_RISK } \mathrm{t}_{\mathrm{t}-1} \text { of all } \\
\text { clients within the sample which are audited by the same audit firm in yeart. } \\
=\text { CLIENT_BUSINESS RISK } \mathrm{t}_{\mathrm{t}-1} \text { of the client company - average } \\
\text { CLIENT_BUSINESS_RISK } \mathrm{t}_{\mathrm{t}-1} \text { of all clients within the sample which are } \\
\text { audited by the same audit firm in year t. }\end{array}$}} \\
\hline REL_CLIENT_BUSINESS_RISK $K_{t-1}$ & & & & \\
\hline AUDITOR_BUSINESS_RISK $\mathrm{t}_{\mathrm{t}-1}$ & \multicolumn{4}{|c|}{ = Dummy variable indicating whether 1 if the client company was listed on } \\
\hline REL_SIZE & \multicolumn{4}{|c|}{$\begin{array}{l}=\mathrm{SIZE}_{\mathrm{t}-1} \text { of the client Company- average } \mathrm{SIZE}_{\mathrm{t}-1} \text { of all clients within the } \\
\text { sample which are audited by the same audit firm, for year t. }\end{array}$} \\
\hline WORKS_COUNCIL $\mathrm{L}_{\mathrm{t}-1}$ & \multicolumn{4}{|c|}{$\begin{array}{l}=\text { Dummy variable indicating } 1 \text { if the client company required a works council } \\
\text { in year } t-1,0 \text { otherwise. }\end{array}$} \\
\hline $\mathrm{BIGN}_{\mathrm{t}}$ & \multicolumn{4}{|c|}{$\begin{array}{l}\text { = Dummy variable indicating whether the client company is audited by a Big } \\
\mathrm{N} \text { audit firm in year } \mathrm{t}(1) \text { or not (0). }\end{array}$} \\
\hline
\end{tabular}

None of the control variables has a significant effect on the general experience of the allocated partner, suggesting partner allocation is not affected by these factors. This finding is in line with prior research which showed no clear effect between these control variables and the need for the use of expert personnel (e.g. Reynolds and Francis 2001; Sercu et al. 2002).

Panel B of Table 2.8 shows the results for the regressions in which partner industry experience is regressed on the risk and control variables. The model is significant for all three samples, and the R-square ranges from 4.00 percent for the full sample, to 4.73 percent for the non-Big $\mathrm{N}$ sample. Variance inflation factors do not indicate that multicollinearity is a concern.

The coefficient for REL_AUDIT_RISK $\mathrm{t}_{\mathrm{t}-1}$ for the full sample is positive and significant at the 5 percent level $(\beta=.011, p<.05)$, providing support for hypothesis 1. Furthermore, the coefficient for REL_AUDIT_RISK $K_{t-1}$ is significant for both the sample of clients of Big $N$ audit firms $(\beta=.009, p<.10)$ and the sample of clients of non-Big $N$ audit firms $(\beta=.035, p<.01)$. This suggests that both Big $\mathrm{N}$ and non Big $\mathrm{N}$ audit firms allocate partners with greater industry experience to clients with a higher audit risk.

The coefficient of REL_CLIENT_BUSINESS_RISK $\mathrm{t}_{\mathrm{t}-1}$ is insignificant across all three samples, hypothesis 2 is therefore rejected. Hence, audit 
Table 2.8 - Panel B: OLS regressions with partner industry experience as the dependent variable for the estimation samples of Big $\mathrm{N}$ clients, Non-Big N clients and all clients.

\begin{tabular}{|c|c|c|c|c|}
\hline & & Big N clients & $\frac{\text { Non-Big N }}{\frac{\text { clients }}{n=312}}$ & $\underline{\text { All clients }}$ \\
\hline Variables & Exp. & Confficientc & Coefficients & Confficionts \\
\hline INTERCEPT & & $\frac{\text { Coefficients }}{.018(1.22)}$ & $\frac{\text { ooemiclents }}{.022(1.22)}$ & $\frac{\text { coefilclents }}{.005(.30)}$ \\
\hline REL_AUDIT_RISK $\mathrm{t}_{\mathrm{t}-1}$ & + & $.009(1.89)^{*}$ & $.035(2.75)^{\star \star *}$ & $.011(2.38)^{\star *}$ \\
\hline REL_CLIENT̄_BUSINESS_RISK & + & $.007(1.29)$ & $-.013(-.79)$ & $.006(1.17)$ \\
\hline AUDITOR_BUSINESS_RISK $K_{\mathrm{t}-1}$ & + & $-.058(-2.11)^{\star *}$ & $-.008(-.24)$ & $-.052(-2.16)^{\star *}$ \\
\hline REL_SIZE E & $?$ & $-.002(-.61)$ & $.012(1.03)$ & $-.001(-.17)$ \\
\hline WORKS_COUNCIL $L_{t-1}$ & $?$ & $-.067(-5.60)^{\star * \star}$ & $-.051(-1.62)$ & $-.067(-6.25)^{\star \star \star}$ \\
\hline $\mathrm{BIGN}_{\mathrm{t}}$ & $?$ & -- & -- & $.016(1.09)$ \\
\hline Adj. R-square & & .0439 & .0473 & .0400 \\
\hline Model F-Value & & $20.55^{\star \star *}$ & $104.31^{\star * *}$ & $452.73^{\star * *}$ \\
\hline Highest VIF & & 2.02 & 2.00 & 1.97 \\
\hline \multicolumn{5}{|c|}{$\begin{array}{l}-{ }^{*},{ }^{* *},{ }^{* * *} \text { Significant at the } 10 \text { percent, } 5 \text { percent levels and } 1 \text { percent levels, respectively. } \\
- \text { The values before the brackets denote the coefficients. The values between brackets denote the t-values. } \\
- \text { All continuous variables are group mean centered, with audit firms as the grouping variable. } \\
\text { - Robust standard errors are used to account for possible correlated observations within clusters of the same audit firm. } \\
\text { - Coefficients for the year dummy variables are not reported for the sake of brevity. } \\
\text { - Variable definitions: }\end{array}$} \\
\hline REL_INDUSTRY_EXPERIENCE $E_{i, t}$ & \multirow{3}{*}{\multicolumn{4}{|c|}{ 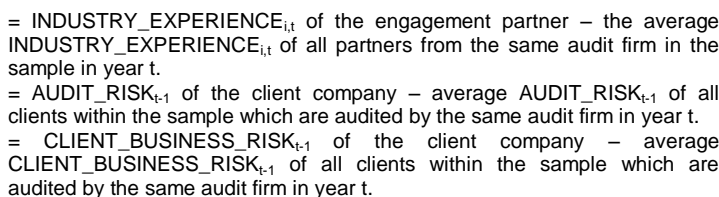 }} \\
\hline REL_AUDIT_RISK $\mathrm{t}_{t-1}$ & & & & \\
\hline REL_CLIENT_BUSINESS_RISK ${ }_{\mathrm{t}-1}$ & & & & \\
\hline AUDITOR_BUSINESS_RISK $K_{t-1}$ & \multirow{4}{*}{\multicolumn{4}{|c|}{$\begin{array}{l}\text { = Dummy variable indicating whether } 1 \text { if the client company was listed on } \\
\text { the Belgian stock exchange in year } t-1,0 \text { otherwise. } \\
=\text { SIZE } \\
\text { sample which are audited by the same audit firm, for year t. } \\
\text { = Dummy variable indicating } 1 \text { if the client company required a works council } \\
\text { in year } t-1,0 \text { otherwise. } \\
\text { = Dummy variable indicating whether the client company is audited by a Big } \\
\mathrm{N} \text { audit firm in year } \mathrm{t}(1) \text { or not }(0) \text {. }\end{array}$}} \\
\hline REL_SIZE $E_{t-1}$ & & & & \\
\hline WORKS_COUNCIL & & & & \\
\hline $\mathrm{BIGN}_{\mathrm{t}}$ & & & & \\
\hline
\end{tabular}

firms do not appear to use audit partner industry experience to manage client business risk.

Opposed to the hypothesized direction, AUDITOR_BUSINESS_RISK has a significantly negative coefficient for the full sample $(\beta=-.052, p<.05)$ and the sample of Big $N$ audit firms $(\beta=-0.58, p<.05)$. The coefficient is positive, but insignificant for the sample of companies audited by non-Big $N$ audit firms $(\beta=-0.08, p>.10)$. A possible explanation for this lack of support for hypothesis 3 is that audit firms may consider client risk to be sufficiently managed by allocating an audit partner with greater general experience.

Hence, while audit firms allocate partners with greater industry experience to clients with a higher audit risk, they do not use industry experience as a risk management strategy for either client business risk or auditor business risk.

The control variable REL_SIZE $\mathrm{t}_{\mathrm{t}-1}$ is insignificant across all three samples, suggesting that client size does not play a role in the partner allocation process.

The control variable WORKS_COUNCIL $\mathrm{L}_{\mathrm{t}-1}$ has a significantly negative coefficient for the full sample $(\beta=-0.067, p<.01)$ and the sample of clients from Big $N$ audit firms $(\beta=-0.067, p<.01)$. The coefficient is negative, but insignificant for the sample of clients from non-Big $N$ audit firms $(\beta=-0.051$, 
$\mathrm{p}>$.10). This suggests that Big $\mathrm{N}$ audit firms allocate a partner with lower industry experience to clients with a works council. A works council may operate as an additional monitoring mechanism, allowing audit firms to allocate an audit partner with less industry experience.

The control variable $B I G N_{t}$ is insignificant for the full sample, indicating no difference in partner industry experience between Big $\mathrm{N}$ and non-Big $\mathrm{N}$ audit firms. Hence, Big N audit firms do not appear to be more likely than non-Big $\mathrm{N}$ auditors to appoint an industry expert to a client.

\subsubsection{Robustness checks}

To verify the robustness of the results reported in the previous section, three robustness checks are performed. First, logistic regressions are used to test whether relatively high (low) client risks result in an increased (decreased) likelihood that a partner with high expertise is allocated. Second, the regressions are tested at the office level instead of the audit firm level to control for the possibility that partner allocation takes place at the local audit office level as opposed to the audit firm level. The final robustness test examines the use of audit partner expertise as a risk management strategy for newly acquired clients.

\subsubsection{Logistic regressions}

Logistic regressions are used to test whether audit firms are more (less) likely to allocate a partner with relatively high expertise to clients with relatively high (low) risks. The dependent variable and the continuous independent variables are recoded into dichotomous variables. For each fiscal year, the values above the median for an audit firm are set to 1,0 otherwise. The models used for estimating a logistic regression are comparable to those used for the OLS regression. The models to examine the use of general experience and industry experience are shown below.

$$
\begin{aligned}
& \text { AM_GENERAL_EXPERIENCE } E_{t}=\beta_{0}+\beta_{1} A M_{-} A U D I T_{-} R I S K_{t-1}+ \\
& \beta_{2} A M_{-} C L I E N T_{-} B U S I N E S S_{-} R I S K_{t-1}+ \\
& \beta_{3} \text { AUDITOR_BUSINESS_RISK } K_{t-1}+\beta_{4} A M_{-} S I Z E_{t-1}+ \\
& \beta_{5} \text { WORKS_COUNCIL }_{t-1}+\beta_{6} \text { BIGN }_{t}+\sum_{7}^{13} \beta_{i} \text { YEAR_DUMMIES }+\varepsilon
\end{aligned}
$$

where:

AM_GENERAL_EXPERIENCE $E_{t}=$ Dummy variable indicating 1 if the general experience of the engagement partner in year $t$ is higher than the median general experience of all partners from the same audit firm in the sample in year $\mathrm{t}, 0$ otherwise;

AM_AUDIT_RISK

$=$ Dummy variable indicating $1(0)$ if the audit risk of the client company in year $\mathrm{t}-1$ is higher (equal or lower) than the median audit risk for year $\mathrm{t}-1$ of all clients within the sample which are audited by the same audit firm in year $\mathrm{t}$;

AM_CLIENT_BUSINESS_RISK $\mathrm{t}_{-1}=$ Dummy variable indicating $1(0)$ if the audit risk of the client company in year t-1 is higher (equal or lower) than the median audit risk for year $\mathrm{t}-1$ of all clients within the sample which are audited by the 
same audit firm in year t; and

AM_SIZE

$=$ Dummy variable indicating $1(0)$ if the size of the client company in year $\mathrm{t}-1$ is higher (equal or lower) than the median size for year $\mathrm{t}-1$ of all clients within the sample which are audited by the same audit firm in year t.

The remaining variables are defined as earlier.

AM_INDUSTRY_EXPERIENCE $E_{t}=\beta_{0}+\beta_{1} A M_{-} A U D I T \_R I S K_{t-1}+$
$\beta_{2}$ AM_CLIENT_BUSINESS_RISK $K_{t-1}+$
$\beta_{3}$ AUDITOR_BUSINESS_RISK $K_{t-1}+\beta_{4} A M_{-}$SIZE $E_{t-1}+$
$\beta_{5}$ WORKS_COUNCIL $L_{t-1}+\beta_{6} B I G N_{t}+\sum_{7}^{13} \beta_{i} Y E A R \_D U M M I E S+\varepsilon$

where:

AM_INDUSTRY_EXPERIENCE ${ }_{t}=$ Dummy variable indicating 1 if the industry experience of the engagement partner in year $t$ is higher than the median industry experience of all partners from the same audit firm in the sample in year t, 0 otherwise.

The remaining variables are defined as earlier.

Panel A of Table 2.9 provides the results of the logistic regressions with general experience as the dependent variable; Panel B of Table 2.9 provides the results for the logistic regressions with industry experience as the dependent variable.

The results of the logistic regressions using general experience as the dependent variable are largely consistent with the results shown in Panel $A$ of Table 2.8. The model has a sufficient fit across all 3 samples, as indicated by the Hosmer and Lemeshow statistic which estimates the lack of fit. The statistic is insignificant for the three samples, therefore indicating no lack of fit. The maximum rescaled R-square ranges from 2.76 percent for the full sample to 7.65 percent for the non-Big $\mathrm{N}$ sample.

The coefficient for AM_AUDIT_RISK $\mathrm{t}_{-1}$ is only significant $(\beta=.486, p<.10)$ for the sample of companies audited by non-Big $N$ audit firms. The coefficient is insignificant for the full sample and the sample of clients of Big $N$ audit firms. These results are consistent with those reported in Panel A of Table 2.8, providing further support for hypothesis 1, confirming that clients of non-Big $\mathrm{N}$ audit firms with a higher audit risk are audited by partners with greater general experience.

The effect of AM_CLIENT_BUSINESS_RISK $\mathrm{t}_{-1}$ is insignificant for the full sample, as well as the two subsamples. This confirms the conclusion that there is no support for hypothesis 2 .

The coefficient for AUDITOR_BUSINESS_RISK $\mathrm{t}_{\mathrm{t}-1}$ is positive and significant for the full sample $(\beta=2.284, p<.01)$ and the Big $N$ sample $(\beta=2.209$, $\mathrm{p}<.01$ ), but no longer significant for the sample consisting of only non-Big $N$ clients $(\beta=13.399, p>.10)$. This provides support for hypothesis 3 , but only for Big $\mathrm{N}$ audit firms. 
Table 2.9 - Panel A: Logistic regressions with general audit partner experience as the dependent variable for the estimation samples of Big N clients, Non-Big N clients and all clients.

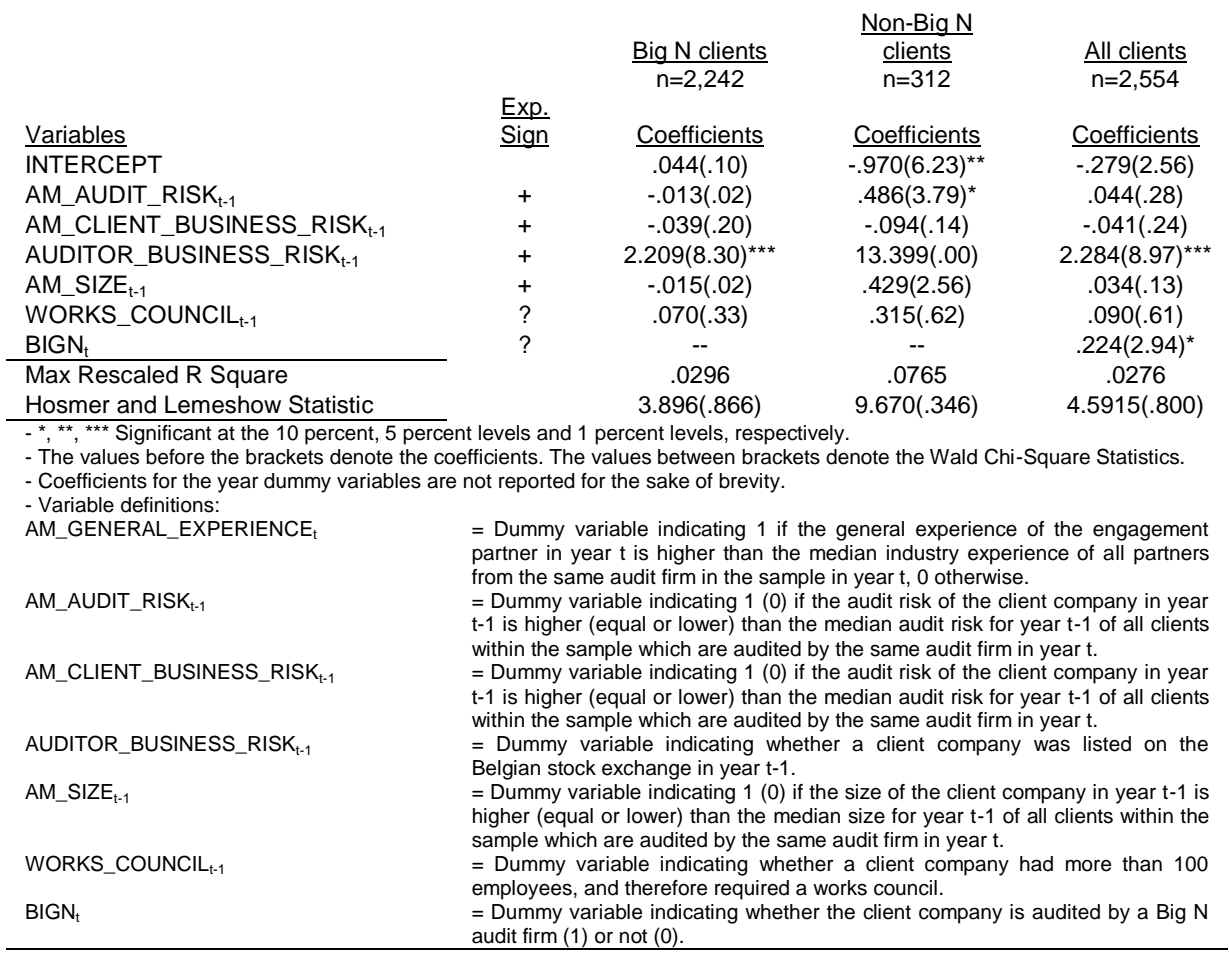

The variable $B I G N_{t}$ has a coefficient of $.224(p<.10)$ for the full sample, providing some evidence that clients of Big $\mathrm{N}$ audit firms are more likely to be audited by a more experienced audit partner than clients of non Big $\mathrm{N}$ audit firms.

Results for the logistic regression for industry experience reported in Panel B of Table 2.9 are generally consistent with those for the robust regression for industry experience in panel $\mathrm{B}$ of Table 2.8. The model is significant for all three samples. The maximum rescaled $\mathrm{R}$-square ranges from 5.17 percent for the Big N sample, to 6.70 percent for the full sample.

The coefficient for AM_AUDIT_RISK $\mathrm{t}_{\mathrm{t}-1}$ remains positive and significant for the full sample $(\beta=.275, p<.01)$, the Big $N$ sample $(\beta=.243, p<.01)$, and the non-Big $N$ sample $(\beta=.543, p<.05)$. This indicates that both Big $N$ and nonBig $N$ audit firms assign partners with a greater industry experience to clients with a higher audit risk, providing further support for hypothesis 1 .

The coefficients for AM_CLIENT_BUSINESS_RISK $\mathrm{t}_{\mathrm{t}-1}$ and AUDITOR_BUSINESS_RISK $\mathrm{t}_{\mathrm{-}-1}$ are insignificant, therefore providing no support for hypotheses 2 and 3 . Thus, audit firms do not seem to use partner industry experience as a risk management strategy for clients that pose either a higher client business risk or a higher auditor business risk.

The control variable WORKS_COUNCIL $\mathrm{L}_{\mathrm{t}-1}$ has a negative and significant coefficient for the sample with Big $N$ clients $(\beta=-.634, p<.01)$, the sample with 
Table 2.9 - Panel B: Logistic regressions with audit partner industry experience as the dependent variable for the estimation samples of Big $\mathrm{N}$ clients, Non-Big $\mathrm{N}$ clients and all clients

\begin{tabular}{|c|c|c|c|c|}
\hline \multirow[b]{4}{*}{ Variables } & \multirow[b]{3}{*}{ Exp. } & \multirow{2}{*}{$\underline{\text { Big N clients }}$} & \multirow{2}{*}{$\frac{\text { Non-Big N }}{\frac{\text { clients }}{n=312}}$} & \multirow{3}{*}{$\underline{\text { All clients }}$} \\
\hline & & & & \\
\hline & & & & \\
\hline & \multirow{2}{*}{$\underline{\overline{\text { Sign }}}$} & Coefficients & Coefficients & Coefficients \\
\hline INTERCEPT & & $.154(1.16)$ & $-1.075(7.23)^{\star \star \star}$ & $-.767(18.71)^{\star \star \star}$ \\
\hline AM_AUDIT_RISK $K_{t-1}$ & + & $.243(7.85)^{\star \star \star}$ & $.543(4.67)^{\star \star}$ & $.275(11.26)^{\star \star \star}$ \\
\hline AM_CLIENT_BUSINESS_RISK $\mathrm{t}_{\mathrm{t}-1}$ & + & $.025(.08)$ & $.091(.13)$ & $.034(.17)$ \\
\hline AUDITOR_BŪSINESS_RISKK $\mathrm{t}_{\mathrm{t}-1}$ & + & $-1.034(2.48)$ & $-11.286(.00)$ & $-1.030(2.48)$ \\
\hline AM SIZE $_{t-1}^{-}$ & ? & $-.027(.07)$ & $.124(.21)$ & $-.005(.00)$ \\
\hline WORKS_COUNCIL $\mathrm{L}_{\mathrm{t}-1}$ & ? & $-.634(27.56)^{\star * *}$ & $-.812(2.88)^{\star}$ & $-.648(31.08)^{\star * *}$ \\
\hline $\mathrm{BIGN}_{\mathrm{t}}$ & $?$ & -- & -- & $.880(44.29)^{\star \star \star}$ \\
\hline Max Rescaled R Square & & .0517 & .0658 & .0670 \\
\hline Hosmer and Lemeshow Statistic & & $3.926(.864)$ & $7.855(.448)$ & $4.920(.766)$ \\
\hline \multirow{2}{*}{\multicolumn{5}{|c|}{$\begin{array}{l}-{ }^{*},{ }^{* *},{ }^{* * *} \text { Significant at the } 10 \text { percent, } 5 \text { percent levels and } 1 \text { percent levels, respectively. } \\
\text { - The values before the brackets denote the coefficients. The values between brackets denote the Wald Chi-Square Statistics. } \\
\text { - Coefficients for the year dummy variables are not reported for the sake of brevity. } \\
\text { - Variable definitions: }\end{array}$}} \\
\hline & & & & \\
\hline AM_INDUSTRY_EXPERIENCE ${ }_{i, t}$ & \multicolumn{4}{|c|}{$\begin{array}{l}\text { = Dummy variable indicating } 1 \text { if the industry experience of the engagement } \\
\text { partner in year } t \text { is higher than the median industry experience of all partners } \\
\text { from the same audit firm in the sample in year } t, 0 \text { otherwise. }\end{array}$} \\
\hline AM_AUDIT_RISK $K_{t-1}$ & \multirow{2}{*}{\multicolumn{4}{|c|}{$\begin{array}{l}=\text { Dummy variable indicating } 1(0) \text { if the audit risk of the client company in year } \\
\mathrm{t}-1 \text { is higher (equal or lower) than the median audit risk for year } \mathrm{t}-1 \text { of all } \\
\text { clients within the sample which are audited by the same audit firm in year } \mathrm{t} \text {. } \\
=\text { Dummy variable indicating } 1 \text { (0) if the audit risk of the client company in year } \\
\mathrm{t}-1 \text { is higher (equal or lower) than the median audit risk for year } \mathrm{t}-1 \text { of all } \\
\text { clients within the sample which are audited by the same audit firm in year } \mathrm{t} \text {. }\end{array}$}} \\
\hline AM_CLIENT_BUSINESS_RISK $K_{t-1}$ & & & & \\
\hline AUDITOR_BUSINESS_RISK $\mathrm{t}_{\mathrm{t}-1}$ & \multicolumn{4}{|c|}{$\begin{array}{l}=\text { Dummy variable indicating whether a client company was listed on the } \\
\text { Belgian stock exchange in year } \mathrm{t}-1 \text {. }\end{array}$} \\
\hline AM_SIZE $E_{t-1}$ & \multicolumn{4}{|c|}{$\begin{array}{l}\text { = Dummy variable indicating } 1(0) \text { if the size of the client company in year } t-1 \\
\text { is higher (equal or lower) than the median size for year } t-1 \text { of all clients within } \\
\text { the sample which are audited by the same audit firm in year t. }\end{array}$} \\
\hline WORKS_COUNCIL $\mathrm{L}_{t-1}$ & \multicolumn{4}{|c|}{$\begin{array}{l}=\text { Dummy variable indicating whether a client company had more than } 100 \\
\text { employees, and therefore required a works council. }\end{array}$} \\
\hline $\mathrm{BIGN}_{\mathrm{t}}$ & \multicolumn{4}{|c|}{$\begin{array}{l}\text { = Dummy variable indicating whether the client company is audited by a Big } \mathrm{N} \\
\text { audit firm (1) or not }(0) \text {. }\end{array}$} \\
\hline
\end{tabular}

non-Big $N$ clients $(\beta=-.812, p<.10)$ and the full sample $(\beta=-.648, p<.01)$, suggesting that audit firms allocate partners with less industry experience to clients that have a works council. This is in line with the argumentation that the presence of a works council operates as a monitoring mechanism which allows allocating a partner with lower expertise. The effect of AM_SIZE $\mathrm{t}_{\mathrm{t}-1}$ is insignificant across all three samples. $\mathrm{BIGN}_{t}$ has a positive association $(\beta=.880, p<.01)$ with the likelihood that an industry expert audits the client, indicating that clients of Big $\mathrm{N}$ audit firms are more likely to be audited by an industry expert than clients of non-Big $\mathrm{N}$ audit firms. This is consistent with the argumentation that partners working for larger audit firms can specialize more into specific industries than auditors working for smaller audit firms (e.g. Craswell et al. 1995).

\subsubsection{Local office analysis}

To control for the possibility that the allocation of experts takes place at the office level as opposed to the audit firm level, models (2.1) and (2.2) are tested at the local audit office level. For this purpose data on audit office locations are added to the sample of 2,554 observations, which was available for all but 43 observations. Subsequently, observations are removed which relate to offices for which only one audit partner accepted new clients during a year, resulting in a reduced sample of 1,411 observations. Models 
(2.1) and (2.2) are used to examine whether the use of audit partner expertise is driven by the local audit office. The main difference from the prior analyses is that audit partner expertise and client risk factors are mean centered at the local practice office instead of the audit firm level.

The results of testing models (2.1) and (2.2) at the office level are displayed in Panels A and B of Table 2.10. Panel A shows the results for general partner experience. Panel $B$ shows the results for partner industry experience. Results in Panel $A$ show that the main difference compared to the regressions ran at the firm level pertains to the variable REL_CLIENT_BUSINESS_RISK $\mathrm{t}_{\mathrm{t}-1}$. Whereas Panel A of Table 2.8 and Panel A of Table 2.9 show no association between client business risk and general partner experience, Panel A of Table 2.10 shows a negative association between REL_CLIENT_BUSINESS_RISK $\mathrm{t}_{\mathrm{t}-1}$ and general partner experience for the full sample $(\beta=-.490, p<.01)$ and the Big $N$ sample $(\beta=-.503, p<.01)$, but not for the non-Big $N$ sample $(\beta=.220, p>.10)$. Hence, like before there is no support for hypothesis 2 . In fact, there is even limited evidence of an effect that is in a direction opposed to hypothesis 2 . This is in line with the argumentation that experienced partners are reluctant to audit clients with a relatively high business risk.

The coefficient for REL_AUDIT_RISK $\mathrm{t}_{-1}$ is insignificant for all three samples. This confirms the prior finding that audit firms do not use general partner experience as a risk management for audit risk. Hence, hypothesis 1 is not supported. The coefficient for AUDITOR_BUSINESS_RISK $\mathrm{t}_{\mathrm{t}-1}$ is positive and significant for the Big $N$ sample $(\beta=5.128, p<.01)$ and the full sample $(\beta=5.157, p<.01)$, but could not be estimated for the sample of non-Big $N$ clients due to a lack of observations with a stock exchange listing. Hence, like before there is evidence in support of hypothesis 3 , but now only for Big $\mathrm{N}$ audit firms.

Panel B of Table 2.10 shows the results for the office level regressions for audit partner industry experience. The adjusted R-square ranges between 6.67 percent for the non-Big N sample and 3.20 percent for the sample consisting of Big $\mathrm{N}$ clients. This suggests that some of the explanatory variables in the sample of the non-Big N firms do not add any value to the model. The coefficients of REL_AUDIT_RISK $\mathrm{t}_{-1}$ and REL_CLIENT_ BUSINESS_RISK $\mathrm{t}_{\mathrm{t}-1}$ are insignificant across all three samples. Therefore there is no support for hypothesis 1 and hypotheses 2. The coefficient for AUDITOR_BUSINESS_RISK $\mathrm{t}_{\mathrm{t}-1}$ is negative and significant for the Big $\mathrm{N}$ sample $(\beta=-.051, p<.01)$ and the full sample $(\beta=-.070, p<.01)$. AUDITOR_BUSINESS_RISK $K_{t-1}$ was not estimated for the sample of non-Big $N$ clients due to a lack of observations with a stock exchange listing. A possible explanation for the lack of evidence on the use of industry experience at the local office is that industry experts may operate on a national level, auditing not only clients of their own local office, but also clients of other local offices (Francis et al. 2005). Furthermore, the coefficient for WORKS_COUNCIL $\mathrm{t}_{\mathrm{t}-1}$ is no longer significant for the non-Big $N$ sample $(\beta=-.012, p>.10)$, while remaining significant for the Big $N(\beta=-.076, p<.01)$ and the full sample $(\beta=-$ $.070, p<.01)$. This could be due to the reduced sample size used in estimat- 
Table 2.10 - Panel A: OLS regressions with general audit partner experience as the dependent variable for the estimation samples of Big $\mathrm{N}$ clients, Non-Big $\mathrm{N}$ clients and all clients. All variables are mean centered at the local office level.

\begin{tabular}{|c|c|c|c|c|}
\hline \multirow[b]{4}{*}{ Variables } & \multirow[b]{3}{*}{ Exp. } & \multirow{2}{*}{$\begin{array}{l}\text { Big N clients } \\
\mathrm{n}=1,286\end{array}$} & \multirow{2}{*}{$\frac{\text { Non-Big N }}{\frac{\text { clients }}{n=125}}$} & \multirow{3}{*}{$\begin{array}{l}\text { All clients } \\
\mathrm{n}=1,411\end{array}$} \\
\hline & & & & \\
\hline & & & & \\
\hline & $\overline{\text { Sign }}$ & Coefficients & Coefficients & Coefficients \\
\hline INTERCEPT & & $.481(.98)$ & $-.107(-.20)$ & $.377(.82)$ \\
\hline REL_AUDIT_RISK $\mathrm{t}_{\mathrm{t}-1}$ & + & $-.049(-.55)$ & $1.477(1.64)$ & $.042(.36)$ \\
\hline REL_CLIENT_BUSINESS_RISK ${ }_{\mathrm{t}-1}$ & + & $-.503(-2.72)^{\star \star \star}$ & $.220(.55)$ & $-.490(-3.22)^{* * *}$ \\
\hline AUDITOR_BUSINESS_RISKK $K_{\mathrm{t}-1}$ & + & $5.128(4.92)^{\star \star *}$ & -- & $5.157(5.36)^{\star * *}$ \\
\hline REL_SIZE & + & $.001(.01)$ & $-.973(-1.88)^{*}$ & $-.043(-.19)$ \\
\hline WORKKS_COUNCIL $L_{t-1}$ & $?$ & $.147(.31)$ & $2.281(1.51)$ & $.313(.83)$ \\
\hline $\mathrm{BIGN}_{\mathrm{t}}$ & $?$ & -- & -- & $.058(.11)$ \\
\hline Adj. R-square & & .0310 & .0530 & .0285 \\
\hline Model F-Value & & 578.86 & 5.70 & 3117.88 \\
\hline Highest VIF & & 1.79 & 2.00 & 1.74 \\
\hline \multicolumn{5}{|c|}{$\begin{array}{l}-{ }^{*},{ }^{* *},{ }^{* *} \text { Significant at the } 10 \text { percent, } 5 \text { percent levels and } 1 \text { percent levels, respectively. } \\
\text { - The values before the brackets denote the coefficients. The values between brackets denote the t-values. } \\
\text { - All continuous variables are group mean centered, with local audit offices as the grouping variable. } \\
\text { - Robust standard errors are used to account for possible correlated observations within clusters of the same audit firm. } \\
\text { - Coefficients for the year dummy variables are not reported for the sake of brevity. } \\
\text { - Variable definitions: }\end{array}$} \\
\hline REL_GENERAL_EXPERIENCE ${ }_{t}$ & \multicolumn{4}{|c|}{$\begin{array}{l}\text { = GENERAL_EXPERIENCE } E_{t} \text { of the engagement partner - the average } \\
\text { GENERAL_EXPERIENCE }{ }_{t} \text { of all partners from the same local office in the } \\
\text { sample in year t. }\end{array}$} \\
\hline REL_AUDIT_RISK $\mathrm{t}_{\mathrm{t}-1}$ & \multicolumn{4}{|c|}{$\begin{array}{l}=\text { AUDIT_RISK } \\
\text { clients within the sample which are audited by the same local office in year } t .\end{array}$} \\
\hline REL_CLIENT_BUSINESS_RISK $\mathrm{t}_{\mathrm{t}-1}$ & \multicolumn{4}{|c|}{$\begin{array}{l}=\text { CLIENT_BUSINESS_RISK } \mathrm{t}_{\mathrm{t}-1} \text { of the client company - average } \\
\text { CLIENT_BUSINESS_RISK } \mathrm{t}_{\mathrm{t}-1} \text { of all clients within the sample which are } \\
\text { audited by the same local office in year } \mathrm{t} \text {. }\end{array}$} \\
\hline AUDITOR_BUSINESS_RISK $\mathrm{t}_{\mathrm{t}-1}$ & \multicolumn{4}{|c|}{$\begin{array}{l}=\text { Dummy variable indicating whether } 1 \text { if the client company was listed on } \\
\text { the Belgian stock exchange in year } t-1,0 \text { otherwise. }\end{array}$} \\
\hline REL_SIZE & \multicolumn{4}{|c|}{$\begin{array}{l}=\mathrm{SIZE}_{\mathrm{t}-1} \text { of the client Company- average } \mathrm{SIZE}_{\mathrm{t}-1} \text { of all clients within the } \\
\text { sample which are audited by the same local office, for year } t .\end{array}$} \\
\hline WORKS_COUNCIL ${ }_{t-1}$ & \multirow{2}{*}{\multicolumn{4}{|c|}{$\begin{array}{l}=\text { Dummy variable indicating } 1 \text { if the client company required a works } \\
\text { council in year } \mathrm{t}-1,0 \text { otherwise. } \\
=\text { Dummy variable indicating whether the client company is audited by a Big } \\
\mathrm{N} \text { local office in year } \mathrm{t}(1) \text { or not }(0) \text {. }\end{array}$}} \\
\hline $\mathrm{BIGN}_{\mathrm{t}}$ & & & & \\
\hline
\end{tabular}

ing the regression for clients of non-Big $\mathrm{N}$ audit firms. The effect of the variable IIGN $_{t}$ remains positive and significant $(\beta=.024, p<.05)$.

\subsubsection{Newly acquired clients}

The analyses thus far focused on the allocation of audit partners to existing clients. Newly acquired clients were not included in the sample because such clients are likely to be audited by the audit partner who attracted them, hence without any kind of internal allocation taking place. ${ }^{25}$ However, as a robustness check, the allocation of partners to new clients is examined. Therefore, out of the sample of 74,730 observations, those observations are selected which relate to audit clients that are new to both the audit firm and the audit partner. Furthermore, only observations of audit firms are included for which more than one audit partner accepted new clients. This is required to measure the relative riskiness of newly accepted clients, as well as the relative expertise of the audit partners accepting new clients. The results of these tests are shown in Panels A and B of Table 2.11, for general partner experience and audit partner industry experience respectively.

Panel A of Table 2.11 shows that the coefficient of REL_AUDIT_RISK $\mathrm{t}_{\mathrm{t}-1}$ is negative and significant for the Big $N$ sample $(\beta=-.434, p<.05)$ and the full sample $(\beta=-.393, p<.05)$, but insignificant for the non-Big $N$ sample $(\beta=-.196$, 
Table 2.10 - Panel B: OLS regressions with partner industry experience as the dependent variable for the estimation samples of Big $\mathrm{N}$ clients, Non-Big $\mathrm{N}$ clients and all clients. All variables are mean centered at the local office level.

\begin{tabular}{|c|c|c|c|c|}
\hline \multirow[b]{3}{*}{ Variables } & \multirow[b]{3}{*}{ Exp. } & \multirow{2}{*}{$\begin{array}{c}\text { Big N clients } \\
n=1,286\end{array}$} & \multirow{2}{*}{$\frac{\text { Non-Big N }}{\frac{\text { clients }}{n=125}}$} & \multirow{3}{*}{$\begin{array}{l}\text { All clients } \\
n=1,411\end{array}$} \\
\hline & & & & \\
\hline & & & & \\
\hline & Sign & Coefficients & Coefficients & Coefficients \\
\hline INTERCEPT & & $.017(2.81)^{\star \star \star}$ & $.004(.47)$ & $-.006(-.53)$ \\
\hline REL_AUDIT_RISK $K_{t-1}$ & + & $-.001(-.15)$ & $.004(.24)$ & $-.001(-.10)$ \\
\hline REL_CLIENT_BUSINESS_RISK ${ }_{\mathrm{t}-1}$ & + & $.002(.36)$ & $-.017(-1.29)$ & $.000(.10)$ \\
\hline AUDITOR_BUSINESS_RISK $K_{t-1}$ & + & $-.051(-2.41)^{\star *}$ & -- & $-.052(-2.69)^{\star \star \star}$ \\
\hline REL_SIZE & $?$ & $.001(.17)$ & $.002(.19)$ & $.000(.06)$ \\
\hline WORKS COUNCIL & ? & $-.076(-3.77)^{\star \star \star}$ & $-.012(-.41)$ & $-.070(-3.63)^{\star \star \star}$ \\
\hline $\mathrm{BIGN}_{\mathrm{t}}$ & $?$ & -- & -- & $.024(2.40)^{\star *}$ \\
\hline Adj. R-square & & .0320 & -.0667 & .0273 \\
\hline Model F-Value & & 16.19 & 23.99 & 1761.96 \\
\hline Highest VIF & & 1.79 & 1.97 & 1.74 \\
\hline \multicolumn{5}{|c|}{$\begin{array}{l}-{ }^{*},{ }^{* *},{ }^{* *} \text { Significant at the } 10 \text { percent, } 5 \text { percent levels and } 1 \text { percent levels, respectively. } \\
\text { - The values before the brackets denote the coefficients. The values between brackets denote the } t \text {-values. } \\
\text { - All continuous variables are group mean centered, with local audit offices as the grouping variable. } \\
\text { - Robust standard errors are used to account for possible correlated observations within clusters of the same audit firm. } \\
\text { - Coefficients for the year dummy variables are not reported for the sake of brevity. } \\
\text { - Variable definitions: }\end{array}$} \\
\hline REL_INDUSTRY_EXPERIENCE $\mathrm{i}_{\mathrm{i}, \mathrm{t}}$ & \multirow{2}{*}{\multicolumn{4}{|c|}{$\begin{array}{l}\text { = INDUSTRY_EXPERIENCE } E_{i, t} \text { of the engagement partner - the average } \\
\text { INDUSTRY_EXPERIENCE } E_{i, t} \text { of all partners from the same local office in the } \\
\text { sample in yeart. } \\
=\text { AUDIT_RISK } \\
\text { within the sample which are audited by the same local office in year t. }\end{array}$}} \\
\hline REL_AUDIT_RISK $\mathrm{t}_{\mathrm{t}-1}$ & & & & \\
\hline REL_CLIENT_BUSINESS_RISK $\mathrm{t}_{-1}$ & \multirow{5}{*}{\multicolumn{4}{|c|}{ 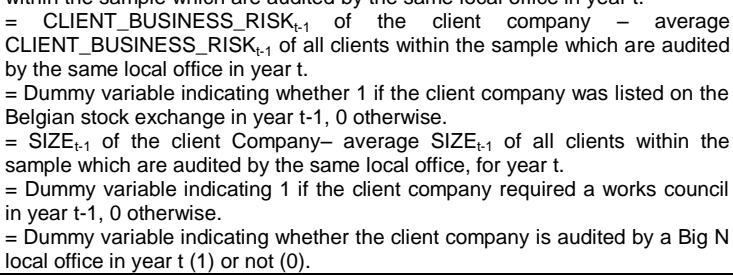 }} \\
\hline AUDITOR_BUSINESS_RISK $\mathrm{t}_{\mathrm{t}-1}$ & & & & \\
\hline REL_SIZE & & & & \\
\hline WORKS_COUNCIL L & & & & \\
\hline $\mathrm{BIGN}_{\mathrm{t}}$ & & & & \\
\hline
\end{tabular}

$p>$.10). These coefficients are in the opposite direction of what is predicted in hypothesis 1 . This indicates that clients of Big $\mathrm{N}$ audit firms which have a higher audit risk are likely to be audited by an audit partner with fewer years of experience as an auditor. It is not possible to assess directly whether less experienced (younger) partners attract relatively riskier clients than more experienced partners, or whether these risky clients are allocated to less experienced partners at a central level. For non-Big $\mathrm{N}$ audit firms there seems to be no relationship between the general experience of a partner and the audit risk of newly attracted clients.

For the sample of clients of non-Big $\mathrm{N}$ audit firms there is no association between REL_CLIENT_BUSINESS_RISK $\mathrm{t}_{\mathrm{t}-1}$ and general partner experience $(\beta=-.583, p>.10)$. The coefficient for the Big $\mathrm{N}$ sample is negative and significant at the 10 percent level $(\beta=-.397, p<.10)$, providing limited evidence that in Big $\mathrm{N}$ audit firms, newly acquired clients with a high client business risk are likely to be audited by less experienced audit partners. This finding is opposed to the expected direction of hypothesis 2 .

The auditor business risk of newly accepted clients (AUDITOR_BUSINESS_RISK $\mathrm{t}_{-1}$ ) is positively associated with the general experience of the audit partner assigned to new clients for the non-Big $\mathrm{N}$ sample $(\beta=4.917, p<.01)$, but insignificant for the full sample $(\beta=-1.285, p>10)$ and 
Table 2.11 - Panel A: OLS regressions with general audit partner experience as the dependent variable for the estimation samples of Big $\mathrm{N}$ clients, Non-Big $\mathrm{N}$ clients and all clients. The sample includes only newly accepted clients.

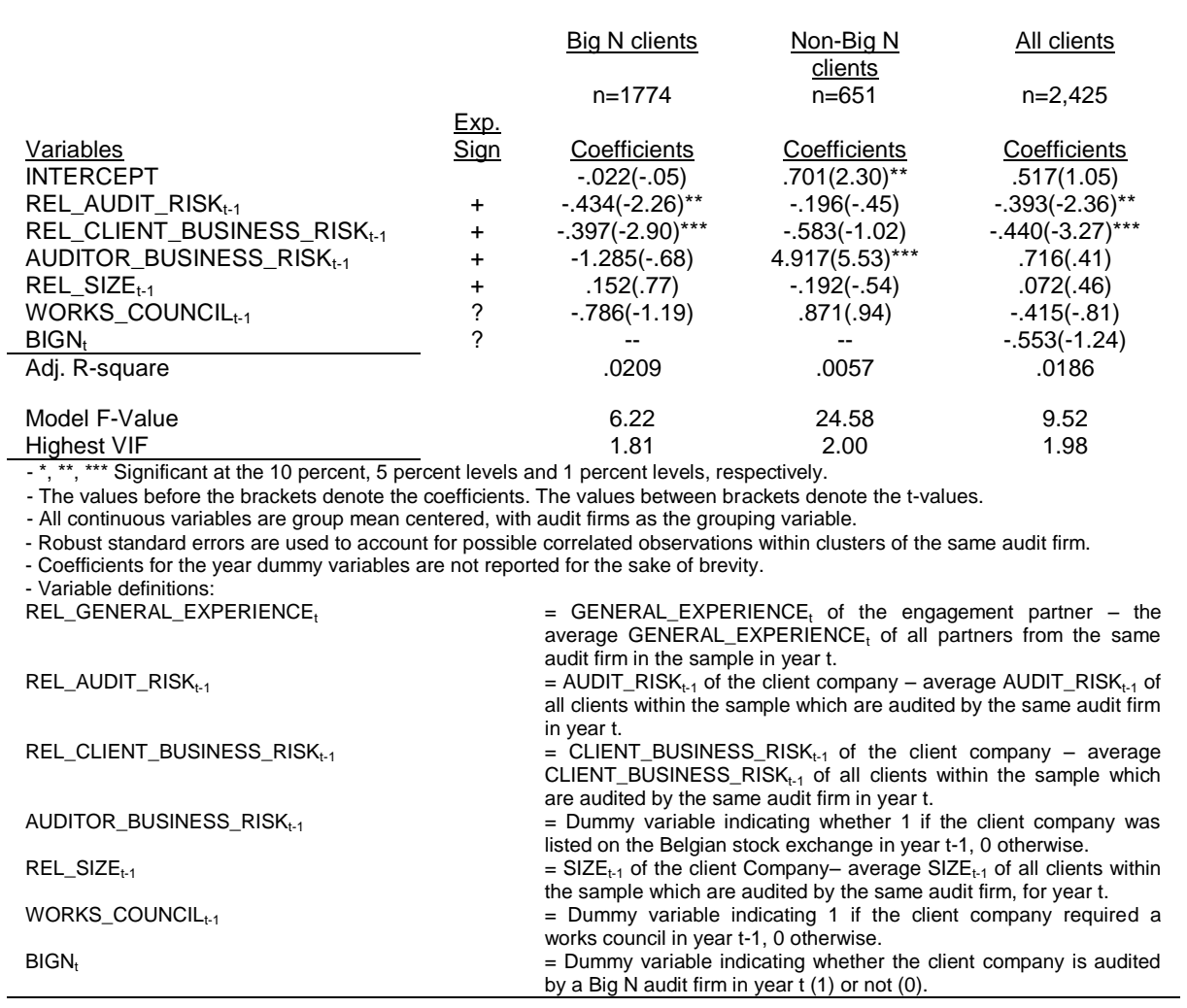

the Big N sample $(\beta=.716, p>.10)$. Hence, hypothesis 3 is supported only for the non-Big $\mathrm{N}$ sample. The effects of the control variables are all insignificant.

Overall, the results of this robustness test suggest that the use of general partner experience as a risk management strategy for newly acquired clients may be based on different factors compared to continuing clients.

Panel B of Table 2.11 shows the outcomes of model (2.2) for newly acquired clients. These results are consistent with those reported for reallocated clients. The model is significant for each of the three samples and the R-square ranges from 5.44 percent for the subsample of Big $\mathrm{N}$ clients to 6.34 percent for the subsample of non-Big N clients. REL_AUDIT_RISK has a positive association with audit partner industry experience for the full sample $(\beta=.038, p<.01)$, as well as the Big $N$ sample $(\beta=.032, p<.01)$ and the non-Big $N$ sample $(\beta=.060, p<.01)$. Consistent with hypothesis 1 , this indicates that new clients with a higher audit risk are audited by partners with greater industry experience than clients with less audit risk. The variables REL_CLIENT_BUSINESS_RISK ${ }_{\mathrm{t}-1}$, AUDITOR_BUSINESS_RISK $\mathrm{t}_{-1}$, and REL_SIZE $E_{t-1}$ of new clients are not significantly associated with the industry 
Table 2.11 - Panel B: OLS regressions with partner industry experience as the dependent variable for the estimation samples of Big $\mathrm{N}$ clients, Non-Big $\mathrm{N}$ clients and all clients. The sample includes only newly accepted clients.

\begin{tabular}{|c|c|c|c|c|}
\hline & \multirow[b]{3}{*}{ Exp. } & \multirow{2}{*}{$\underline{\mathrm{Big} N \text { clients }}$} & \multirow{2}{*}{$\frac{\text { Non-Big N }}{\frac{\text { clients }}{n=651}}$} & \multirow{3}{*}{ All clients } \\
\hline & & & & \\
\hline Variables & & & & \\
\hline & Sign & Coefficients & Coefficients & Coefficients \\
\hline INTERCEPT & & $.001(.08)$ & $-.019(-.98)$ & $-.002(-.25)$ \\
\hline REL_AUDIT_RISK $\mathrm{t}_{\mathrm{t}-1}$ & + & $.032(17.89)^{\star \star \star}$ & $.060(2.78)^{\star \star *}$ & $.038(6.84)^{\star \star *}$ \\
\hline REL_CLIENT'BUSINESS_RISK & + & $-.008(-1.14)$ & $.016(1.23)$ & $-.004(-.73)$ \\
\hline AUDITOR_BUSINESS_RISKK $K_{t-1}$ & + & $.058(.78)$ & $.102(1.58)$ & $.072(1.39)$ \\
\hline REL_SIZE & $?$ & $.000(.12)$ & $.013(.70)$ & $.004(.75)$ \\
\hline WORKS_COUNCIL $\mathrm{L}_{\mathrm{t}-1}$ & $?$ & $-.056(-14.26)^{\star \star \star}$ & $-.062(-2.87)^{\star \star \star}$ & $-.059(-8.66)^{\star \star \star}$ \\
\hline $\mathrm{BIGN}_{\mathrm{t}}$ & $?$ & -- & -- & $.001(.06)$ \\
\hline Adj. R-square & & .0544 & .0634 & .0553 \\
\hline Model F-Value & & 214.97 & 5.52 & 111.40 \\
\hline Highest VIF & & 1.81 & 3.11 & 1.98 \\
\hline \multicolumn{5}{|c|}{$\begin{array}{l}-{ }^{*},{ }^{* *},{ }^{* *} \text { Significant at the } 10 \text { percent, } 5 \text { percent levels and } 1 \text { percent levels, respectively. } \\
\text { - The values before the brackets denote the coefficients. The values between brackets denote the t-values. } \\
\text { - All continuous variables are group mean centered, with audit firms as the grouping variable. } \\
\text { - Robust standard errors are used to account for possible correlated observations within clusters of the same audit firm. } \\
\text { - Coefficients for the year dummy variables are not reported for the sake of brevity. } \\
\text { - Variable definitions: }\end{array}$} \\
\hline REL_INDUSTRY_EXPERIENCE $E_{i, t}$ & \multirow{2}{*}{\multicolumn{4}{|c|}{$\begin{array}{l}\text { = INDUSTRY_EXPERIENCE } E_{i, t} \text { of the engagement partner - the average } \\
\text { INDUSTRY_EXPERIENCE }{ }_{i, t} \text { of all partners from the same audit firm in the } \\
\text { sample in yeart. } \\
=\text { AUDIT_RISK } \\
\text { within the sample which are audited by the same audit firm in year t. }\end{array}$}} \\
\hline REL_AUDIT_RISK $\mathrm{t}_{\mathrm{t}-1}$ & & & & \\
\hline REL_CLIENT_BUSINESS_RISK $\mathrm{t}_{\mathrm{t}-1}$ & \multicolumn{4}{|c|}{$\begin{array}{l}\text { CLIENT_BUSINESS_RISK } \text { ti }_{-1} \text { of the client company - average } \\
\text { CLIENT_BUSINESS_RISK } K_{\mathrm{t}-1} \text { of all clients within the sample which are audited } \\
\text { by the same audit firm in year t. }\end{array}$} \\
\hline AUDITOR_BUSINESS_RISK $K_{\mathrm{t}-1}$ & \multicolumn{4}{|c|}{$\begin{array}{l}\text { = Dummy variable indicating whether } 1 \text { if the client company was listed on the } \\
\text { Belgian stock exchange in year t- } 1,0 \text { otherwise. }\end{array}$} \\
\hline REL_SIZE & \multirow{2}{*}{\multicolumn{4}{|c|}{$\begin{array}{l}=S E_{t-1} \text { of the client Company- average } \text { SIZE }_{\mathrm{t}-1} \text { of all clients within the } \\
\text { sample which are audited by the same audit firm, for year t. } \\
=\text { Dummy variable indicating } 1 \text { if the client company required a works council } \\
\text { in year } t-1,0 \text { otherwise. }\end{array}$}} \\
\hline WORKS_COUNCIL & & & & \\
\hline $\mathrm{BIGN}_{\mathrm{t}}$ & \multicolumn{4}{|c|}{$\begin{array}{l}=\text { Dummy variable indicating whether the client company is audited by a Big } N \\
\text { audit firm in year } t(1) \text { or not (0). }\end{array}$} \\
\hline
\end{tabular}

experience of the audit partner. Newly attracted clients with a works council are audited by partners with less industry experience. Finally, the coefficient of Big $N$ is insignificant $(\beta=.001, p>.10)$, suggesting that, before taking client risks into account, clients of Big $\mathrm{N}$ and clients of non-Big $\mathrm{N}$ firms are equally likely to be audited by an industry expert.

Summarizing the robustness checks, the results of the logistic regressions show that audit partner industry experience is used by non-Big $\mathrm{N}$ firms as a risk management strategy for audit risk, providing limited evidence for hypothesis 1. No support is found for the use of audit partner expertise as a risk management strategy for newly accepted clients. Similarly, the office level analysis shows no significant association between partner industry experience and audit risk, possibly because industry experts in Belgium are allocated at a national level instead of a local office level. Since Belgium is a geographically small country, it is viable for industry experts to travel to most of the audit firm's clients.

Neither the main analysis nor the robustness checks provide evidence that audit partner expertise is used as a risk management strategy for client business risk, hence there is no support for hypothesis 2 . In fact, the regressions for the local office level and for newly accepted clients show that general partner experience is negatively associated with client business risk. 
This could indicate that more experienced partners may attempt to avoid being allocated to clients with increased client business risk.

The results from the logistic regressions and the local office level regressions show that general partner experience is used as a risk management strategy for auditor business risk, providing further support for hypothesis 3 .

\subsection{Conclusions and limitations}

\subsubsection{Conclusions}

The use of risk management strategies is important for an audit firm to manage the impact of client risks (i.e. audit risk, client business risk and auditor business risk) to reduce the possibility of incurring a loss on an engagement. Prior studies have examined the use of experience as a risk management strategy by looking at the planned allocation of partner or manager hours, but the actual use of partner expertise has not yet been examined. This study contributes to the literature by testing the actual use of partner expertise as a risk management strategy using data from a complete audit market.

From a risk management perspective as well as from a cost minimization perspective it can be argued that audit firms benefit most from allocating partners with the most expertise to audit clients with the greatest risk. However, due to personal liability issues and practice development concerns audit partners might be reluctant to audit clients that pose a high risk, which could result in a less than optimal allocation of partners across clients. It is therefore important to examine whether audit firms conform to audit standards by allocating partners with more expertise to clients that pose greater risks, or whether personal interests dominate resulting in less than optimal partner allocation, posing possibly high risks to the audit firms.

This study uses Belgian data on audits conducted between 1998 and 2006. The requirement that Belgian audit reports are signed with both the name of the audit firm as well as the name of the responsible audit partner enables the construction client portfolios at both the firm and the partner level. Data from the Belgian Institute of Auditors furthermore allow the construction of partner expertise measures. Together, this enables testing the actual use of audit partner expertise as a risk management strategy, as opposed to the planned allocation used in prior studies.

Two measures of partner expertise are used in this study: general partner experience and partner industry experience. The results show that audit firms assign partners with more general experience to clients with higher auditor business risk. The use of expertise as a risk management strategy is further supported by the allocation of partners with more industry experience to clients that pose a higher audit risk. In addition, there is some support that non-Big $\mathrm{N}$ audit firms assign partners with greater general experience to clients with increased audit risk. No evidence is found that supports the use of partner expertise a risk management strategy for clients with a high client business risk. The lack of support for hypothesis 2 does not necessarily 
mean that client business risk is managed ineffectively, since other risk management strategies may be used to manage this type of client risk.

Overall, the results support the main research question that audit partner expertise is used a risk management strategy. This finding is consistent with the requirements posed by auditing standards to adjust audit team composition based on client risk characteristics. However, audit firms and audit regulators should consider why general experience is only used as a risk management strategy for auditor business risk. It is possible that audit partners with more years of experience are unwilling to audit clients that pose greater risks, unless a client is publicly listed due to prestige and career perspectives associated with audits of publicly listed clients. Audit risk and client business risk might therefore not be effectively managed. Hence, audits might benefit from rules and regulation to ensure that general partner experience is used to manage audit risk and auditor business risk.

\subsubsection{Limitations}

There are some limitations to this study. First of all, given that the research is conducted using public data, it is not possible to control for all other risk management strategies which an audit firm could use. This issue has been partly resolved by using a sample in which most of the other risk management strategies are unlikely to be used, and in which the use of partner expertise as a risk management strategy is most likely to occur.

Related to this is the issue that this study relies on public proxies of risk. Private measures of risk might be able to more accurately represent client risk, but are subject to a possible bias by the audit partner.

Finally, the use of Belgian data might be considered an issue because this setting is in many ways different from the US setting, which is commonly researched. The most prominent difference is that Belgium has a low litigious environment. However, prior research has shown that there are other mechanisms in place which make sure that audit quality is maintained at a sufficiently high level (Gaeremynck and Willekens 2003). In fact, it is even more likely that audit partner expertise is used as a risk management strategy in more litigious environments where the possible impact of unmanaged risks is greater.

\subsubsection{Future research}

The current study examines the use of partner expertise as a risk management strategy in a setting in which partner expertise is the most likely risk management strategy. This setting is chosen to reduce the confounding impact of other potential risk management strategies. It would be valuable for future research to examine how firms make trade-offs between risk management strategies, and whether these risk management strategies operate as complements or substitutes.

In addition, this study measures industry experience based on the sales revenues and total assets of the audit clients. Future research could incorporate audit fee data to measure market share and industry experience more accurately. 


\section{Appendix 2.A: Description of IBR membership lists}

In Belgium, every auditor has to be registered with the IBR, the Belgian institute of auditors to practice auditing. From 1961 onwards the IBR has provided an annual overview of the auditors registered at the institute as part of their annual report.

The annual overview consists of two lists. List A gives an overview of the names of the registered auditors, the date of first registration as an auditor, the spoken language of the auditors (Dutch or French), the audit firm they are associated with and their function within this firm. Since the year of the first registration is given, the years of experience as an auditor can be computed. Audit partner experience can be computed from 1956 onwards. From the membership lists it shows that 1965 was the first year in which two auditors merged forces into one audit firm. From this year onwards the membership lists can also be used to provide insight into audit firm structures. List $B$ provides additional information regarding audit firms since 1972. In this year the IBR first provided an overview of the audit firms that were registered at the institute, providing, amongst others, information regarding the location of the audit firm.

In 1994 the audit firm structures became more complex, showing subsidiaries within audit firm organizations and the use of privately owned companies by auditors, used to acquire capital. To obtain insight into the primary audit firm an auditor is associated with (i.e. the firm that is actually used when signing the auditor's report), auditors need to be matched to the appropriate primary firm, as described in appendix B.

\section{Appendix 2.B - Overview of data selection steps}

This study relies on data from two sources, the Bel-First database and the IBR membership lists, which have to be matched. This section discusses steps that are taken take to match the two databases and to prepare the data for the regression analyses.

\section{Matching the Bel-First database with list A of the IBR membership lists}

1. In case of multiple audit partners or audit firms per audit client, those audit partners are removed that are not active anymore according to the IBR (i.e. those who are no longer registered in the IBR membership lists).

2. In case of multiple audit partners or audit firms per audit client, those audit partners and those audit firms are removed for which the mandate starts in the future.

3. If there still are multiple audit partners or audit firms per audit client, those audit partners and audit firms are removed for which the appointment date plus 3 years does not include the fiscal year, under the condition that for one of the other partners/firms the mandate does include the fiscal year. A cut-off of 3 years is used because audits in Belgium are assigned based on 3 year renewable contracts. 
4. If according to the database an audit partner belongs to multiple audit firms in one year (which could be due to spelling issues), then the firm for this partner is set to that firm which is most often mentioned for this partner within the same year, excluding observations for which the firm is initially unknown, or for which there are multiple partners.

5. If still no audit firm is identified for a partner, then the firm as mentioned on the membership lists is used. The identification of the appropriate firm based on the membership lists is discussed in the next section. ${ }^{26}$

\section{Matching procedure within the IBR membership lists}

List $A$ of the membership lists provides an audit firm name with which the audit partner is associated. The audit firm mentioned in list A may however be used just to acquire capital and may be a subsidiary of another audit firm which is actually responsible for conducting audits of financial statements. To accurately identify the audit firm for which the audit partner works, it is necessary to match subsidiary audit firms to their parent firms. Matching audit firms mentioned in List $A$ of the membership lists, to parent firms is done based on audit firm structures as described in List B of the membership lists. The firm which actually is responsible for conducting audits is labeled as the primary audit firm. A number of rules are used to complete this matching, since it is possible for an auditor to be mentioned as a partner or manager of multiple firms, while a firm can also be a subsidiary of multiple firms, sometimes resulting in complex audit firm structures.

Whether an audit firm is merged with a parent firm depends on the number of partners and managers that are listed for both the parent company and the subsidiary. When the total of partners and managers listed for the parent company exceeds the total number of partners and managers listed for the subsidiary, then for those auditors working at the subsidiary the parent company is recoded to be the auditor's primary audit firm.

If an audit firm is listed as a subsidiary of multiple audit firms whose total number of partners and managers are at least equal to the total of partners and managers working at the subsidiary, then the firm with the largest total number is classified as the primary audit firm of the partners working at the subsidiary.

When the number of partners plus managers at the parent company is smaller than this number for the subsidiary, then the subsidiary is classified as the auditor's primary audit firm.

This procedure is repeated until all auditors are assigned only to a primary audit firm. This primary audit firm is used for those audit partners for whom no audit firm is identified using the Bel-First database. 


\section{Chapter 2}

\section{Appendix 2.C}

Table: Number of observations per industry $(n=74,730)$

\begin{tabular}{|c|c|c|}
\hline$\frac{\text { NACE } 2 \text { digit }}{\text { industry code }}$ & Description & $\begin{array}{l}\text { Number of } \\
\text { observations }\end{array}$ \\
\hline 10 & Mining of coal and lignite; extraction of peat & 112 \\
\hline 11 & $\begin{array}{l}\text { Extraction of crude petroleum and natural gas; service activities incidental to oil } \\
\text { surveying and gas extraction excluding }\end{array}$ & 104 \\
\hline 12 & Coal mining & 126 \\
\hline 13 & Mining of metal ores & 37 \\
\hline 14 & Other mining and quarrying & 413 \\
\hline 15 & Manufacture of food products and beverages & 2,726 \\
\hline 16 & Manufacture of tobacco products & 85 \\
\hline 17 & Manufacture of textiles & 1,420 \\
\hline 18 & Manufacture of wearing apparel; dressing and dyeing of fur & 352 \\
\hline 19 & $\begin{array}{l}\text { Tanning and dressing of leather; manufacture of luggage, handbags, saddlery, harness } \\
\text { and footwear }\end{array}$ & 56 \\
\hline 20 & $\begin{array}{l}\text { Manufacture of wood and of products of wood and cork, except furniture; manufacture } \\
\text { of articles of straw and manufacture plaiting materials }\end{array}$ & 497 \\
\hline 21 & Manufacture of pulp, paper and paper products & 547 \\
\hline 22 & Publishing, printing and reproduction of recorded media & 1,337 \\
\hline 23 & Manufacture of coke, refined petroleum products and nuclear fuel & 92 \\
\hline 24 & Manufacture of chemicals and chemical products & 1,729 \\
\hline 25 & Manufacture of rubber and plastic products & 1,060 \\
\hline 26 & Manufacture of other non-metallic mineral products & 1,430 \\
\hline 27 & Manufacture of basic metals & 604 \\
\hline 28 & Manufacture of fabricated metal products, except machinery and equipment & 2,031 \\
\hline 29 & Manufacture of machinery and equipment n.e.c. & 1,457 \\
\hline 30 & Manufacture of office machinery and computers & 93 \\
\hline 31 & Manufacture of electrical machinery and apparatus n.e.c. & 543 \\
\hline 32 & Manufacture of radio, television and communication equipment and apparatus & 265 \\
\hline 33 & Manufacture of medical, precision and optical instruments, watches and clocks & 310 \\
\hline 34 & Manufacture of motor vehicles, trailers and semi-trailers & 574 \\
\hline 35 & Manufacture of other transport equipment & 161 \\
\hline 36 & Manufacture of furniture; manufacturing n.e.c. & 987 \\
\hline 37 & Recycling & 352 \\
\hline 45 & Construction & 4,243 \\
\hline 50 & $\begin{array}{l}\text { Wholesale and retail trade; repair of motor vehicles, motorcycles and personal and } \\
\text { household goods }\end{array}$ & 2,964 \\
\hline 51 & $\begin{array}{l}\text { Wholesale and retail trade, with the exception of repair of motor vehicles and motor- } \\
\text { cycles }\end{array}$ & 20,969 \\
\hline 52 & $\begin{array}{l}\text { Retail trade, with the exception of repair of motor vehicles and motorcycles; repair of } \\
\text { household goods }\end{array}$ & 2,788 \\
\hline 55 & Hotels and restaurants & 675 \\
\hline 60 & Land transport; transport via pipelines & 2,379 \\
\hline 61 & Water transport & 196 \\
\hline 62 & Air transport & 64 \\
\hline 63 & Supporting and auxiliary transport activities; activities of travel agencies & 3,070 \\
\hline 64 & Post and telecommunications & 386 \\
\hline 70 & Real estate, renting and business activities & 4,218 \\
\hline 71 & $\begin{array}{l}\text { Sellers of machinery and equipment without operator and of personal and household } \\
\text { goods }\end{array}$ & 663 \\
\hline 72 & Computer and related activities & 1,705 \\
\hline 73 & Research and development & 113 \\
\hline 74 & Other business activities & 8,766 \\
\hline 75 & Public administration and defence; compulsory social security & 55 \\
\hline 80 & Education & 109 \\
\hline 85 & Health and social work & 303 \\
\hline 90 & Sewage and refuse disposal, sanitation and similar activities & 406 \\
\hline 91 & Activities of membership organization n.e.c. & 18 \\
\hline 92 & Recreational, cultural and sporting activities & 760 \\
\hline 93 & Other service activities & 341 \\
\hline 95 & Private households with employed persons & 2 \\
\hline 99 & Extra-territorial organizations and bodies & 37 \\
\hline Total & & 74,730 \\
\hline
\end{tabular}




\section{Notes}

${ }^{1}$ The number of years of experience is often argued to be the main driver of expertise (Hamilton and Wright 1982).

${ }^{2}$ Reductions in the extent of testing are indicated to be mainly driven by either an improvement in the client's internal control system or favorable results from the prior year's audit. Reasons for increases in the extent of testing are more varied, such as: changes in the client environment, a poor quality of client-prepared data, detected problems during initial testing or analytical procedures, and concerns about obsolescence or a cut-off problems.

${ }^{3}$ Vander Bauwhede and Willekens (2004) show that the amount of listed companies is small (150) relative to the number of companies that file their financial statements at the National Bank of Belgium (250.000) and relative to the number of inhabitants (in contrast to the UK and the US).

${ }^{4}$ In Belgium, audits are assigned based on three year renewable contracts, known as mandates. These contracts can only be ended early under exceptional circumstances. The aim of requiring three year mandates is to prevent low-balling behavior by audit firms, which could reduce audit quality in the first year(s) of the engagement since auditors may have incentives to under staff engagements in order to outbid the competing audit firms.

${ }^{5}$ Possible other reasons for audit partner changes include partner rotation structures, partner retirement, partner movement to another audit firm, and partners acquiring a different function within the audit firm.

${ }^{6}$ This includes cases where two partners from the same audit firm are responsible for the audit engagement, as well as cases where audit partners from different firms are jointly conducting the audit.

${ }^{7}$ Further tests show that clients audited by multiple audit partners are significantly more likely to have a high auditor business risk than clients audited by a single audit partner. No statistically significant difference is found for audit risk and client business risk. This suggests that the allocation of multiple audit partners is used as a risk management strategy for auditor business risk, but not for audit risk and client business risk.

${ }^{8}$ If only one partner is accepting re-allocated clients, this partner's expertise is equal to the average expertise of the firm. By construction, this results in a relative expertise measure of zero.

${ }^{9}$ Bonner and Lewis (1990) identify four determinants of expertise, which are: general domain knowledge, subspecialty knowledge, general business knowledge, general problem-solving ability. General domain knowledge, general business knowledge and general problem-solving ability are acquired through training and general experience. Subspecialty knowledge relates to industry or client specific knowledge.

${ }^{10}$ In total there are 48 auditors who left the audit profession for a certain period of time. These auditors are not penalized for the years not spent in the profession, since the experience they gained outside of the profession may have increased their expertise. Removing companies audited by any of these 48 audit partners or penalizing these audit partners by subtracting the years spent outside the audit profession does not substantially change the results.

${ }^{11}$ Comparable results are obtained when industry experience is measured using the ratio of the number of audited clients within an industry to the total number of audited clients, or the ratio of audited assets within an industry divided by the total assets of all audited clients. 
${ }^{12}$ Audit risk can be subdivided into inherent, control risk, and detection risk. There are no proxies for control risk available in the current setting, and detection risk is a function of auditor effort. This study, therefore, focuses on the inherent risk component of audit risk.

${ }^{13}$ This issue is addressed by means of a factor analysis as discussed in section 4.2.

${ }^{14}$ While it may be argued that some of these control variables are also related to client risks, the factor analysis conducted in section 4.2 shows that they do not load on any of the risk factors. This justifies treating these variables as control variables instead of risk variables.

${ }^{15}$ The Big N is defined as Arthur Andersen. Deloitte, Ernst \& Young, KPMG and PwC. Arthur Andersen ceased to exist after the Enron scandal, and is therefore only included in the first four years of the sample.

${ }^{16}$ All variables have been winsorized at the top and bottom 1 percent to reduce the impact of outliers in the further analyses.

${ }^{17}$ An inspection of notes of annual meetings of shareholders shows that the audit partner assignment is officially confirmed during the annual general meeting of shareholders.

${ }^{18}$ Shapiro et al. (2002) warn that the usage of dichotomous variables in factor analyses may result in unexpected findings. They report that 19 randomly and independently generated dummy variables can result in 5 factor solutions explaining 30 percent of the total variance and rotated loadings exceeding the traditional .40 cutoff. Therefore, dichotomous variables are not included in the factor analysis, and are included into the regression models without further modifications.

${ }^{19}$ Common factor analysis is also referred to as principal axis factoring.

${ }^{20}$ The latent root criterion suggests retaining only factors which have an eigenvalue exceeding one.

${ }^{21}$ Compared to an orthogonal rotation, an oblique rotation method is more realistic since it does not require the assumption that the underlying dimensions are uncorrelated with each other.

${ }^{22}$ When using the orthogonal VARIMAX rotation method the factor loadings are similar to the ones obtained with the oblique PROMAX rotation method.

${ }^{23}$ The results are robust to substituting the audit risk, client business risk and size factors by any of the single variables which compose the factors.

${ }^{24}$ Note though that all the regression models are significant at the 1 percent level.

${ }^{25}$ Assuming that there is a reasonable match between client riskiness and audit partner expertise.

${ }^{26}$ The Bel-First database is used as the main source to identify the audit firm, since this database contains the names of the audit partner and audit firm as mentioned in the financial statements, whereas the IBR membership lists require a matching procedure to identify the audit firm. The results are robust to using the audit firm identified using the IBR membership lists for all observations 


\title{
Chapter 3 \\ The Influence of Auditor-Client Economic Bonding on Audit Quality
}

\begin{abstract}
Auditors receive audit fees from the clients they audit. This creates an economic bond between the auditor and the client. Regulators have expressed concerns about auditorclient economic bonding, alleging that strong auditor-client economic bonding impairs audit quality. This study uses data on audits conducted in Belgium to examine whether auditors acquiesce to pressure from their more influential clients to provide more room for earnings management, thereby compromising audit quality. Results show that audit quality is lower for clients on which auditors are more economically dependent, but only when these clients engage in upward earnings management. Audit quality is not reduced when clients manage their earnings downwards, possibly because the auditor fears that income decreasing earnings management by the client will be detected by the tax authorities. The results suggest that public oversight is important to guarantee high audit quality.
\end{abstract}

Key Words: Auditor-Client Economic Bonding, Auditor Independence, Earnings Management, Audit Quality.

\subsection{Introduction}

This study examines whether increased economic client dependence reduces audit quality. The objective of a financial statement audit is to express an opinion on the reliability of the financial statements (ISA 200; AU110). ${ }^{1}$ The perceived credibility of the audit opinion, hence the value of the audit, is influenced by the perception of the economic dependence of the auditor on the client (Khurana and Raman 2006).

Because clients pay their auditor to perform an audit, auditors may never be entirely independent from their clients, which could create a general bias in favor of clients (Mautz and Sharaf 1961; AICPA 1978; Wallman 1996). Auditors are economically dependent on clients for the audit fees. Clients are dependent on auditors for the auditor reports. Although auditors have few incentives to compromise audit quality when economic bonding to a client is limited, they may have greater difficulty in maintaining their independence from clients for which the audit fees are relatively large given their client portfolio. Strong economic bonding to a client can increase the willingness of an auditor to accept questionable management assertions in order to retain the client and the future audit fees associated with that client (AICPA 1978; Commission on Public Trust and Private Enterprise 2003). This would 
reduce audit quality and harm the informativeness of the financial statements.

While large clients are more likely to constitute economic dependence than smaller clients, they also pose higher risks in case of an audit failure (Reynolds and Francis 2001). Litigation costs are positively correlated with client size (Lys and Watts 1994), and the negative impact of an audit failure on the auditor's reputation can be expected to be higher for a large client than for a small client. These size-related risks could therefore induce auditors to remain independent from their larger clients, allowing large clients similar, or even less discretion to manage earnings than smaller clients (Reynolds and Francis 2001). Hence, possible litigation and reputation costs have an off-setting effect on audit quality. The effect of auditor-client economic bonding on audit quality is therefore an empirical question.

When examining the effect of economic bonding on audit quality, it is important to focus on the appropriate level of decision making within an audit firm for at least two reasons. The first reason is that the costs of reputation losses and litigation may not be sufficient to offset the incentives to retain large clients because these costs are borne by the whole audit firm, while the benefits accrue to the individual partner or the local office (Reynolds and Francis 2001). Hence, there could be a moral hazard problem where audit partners do not make decisions which are in the best interest of the audit firm. The second reason is that while it is unlikely that a single client is a significant source of revenue for an audit firm, a single client can be a significant source of revenue for a local office or an audit partner (Wallman 1996; Francis et al., 1999). The Enron audit failure illustrates this. Although the fees earned from the Enron engagement were only $1 \%$ of the total fees earned by Arthur Andersen, the audit fees from Enron accounted for about $27 \%$ of the audit fees of public clients for Arthur Andersen's Houston office (Healy and Palepu 2003). This underlines the importance of measuring client dependence at the level within the audit firm at which auditor independence is impaired. The current study therefore examines three levels of analysis: the audit firm level, the local office level, and the audit partner level.

Using Belgian data on audits conducted for fiscal year 2006, this study examines whether auditors are able to withstand pressure from their larger clients to allow earnings management. Whether auditors acquiesce to client pressure to allow earnings management depends on potential reputation concerns, litigation losses and regulatory fines. Belgium has a low litigious environment. Litigation concerns are therefore unlikely to provide an incentive for auditors to refrain from allowing more earnings management discretion to clients on which they are economically dependent. Reputation risk is generally smaller for privately held companies than for publicly traded companies. The extent of public oversight in Belgium depends on whether clients engage in income increasing or income decreasing earnings management. Tax authorities are more likely to detect downward, tax reducing, earnings management than upward earnings management. This setting therefore enables testing whether reputation concerns by auditors are sufficient to offset pressure from clients to allow earnings management, or 
whether public oversight is needed to ensure that audit quality is maintained at a sufficient level. ${ }^{2}$

Results indicate that auditors allow more upward earnings management discretion to clients on which they are more economically dependent. Hence, audit quality is impaired when an auditor has high economic dependence on a single client. This suggests that reputation concerns by auditors are not sufficient to offset pressure from clients to allow earnings management. Auditors do however constrain downward earnings management more for clients that constitute a strong economic bond. This finding is consistent with Vander Bauwhede et al. (2003) who state that auditors may constrain downward earnings management because they fear that this type of earnings management will be detected by the tax authorities. Hence, the results suggest that public oversight is required to prevent auditors from providing more earnings management discretion to clients on which they have a greater economic dependence.

This paper contributes to the literature on audit quality in several ways. First, this paper includes both public and private firms in the sample. Client acceptance and retention decisions are based on entire auditor portfolios (Simunic and Stein 1990). The importance of a client for an auditor depends not only on the audit fees obtained from that client, but also on the audit fees of the remaining clients. Whereas prior studies examined the effect of auditor-client economic bonding on audit quality based on samples consisting of publicly listed clients only, this study incorporates both publicly listed and privately held companies, thereby providing more insightful results than prior studies. The inclusion of both publicly and privately held companies results in a more accurate measure of auditor-client economic bonding than one based solely on publicly traded companies. Prior studies use data on public clients only, leaving out private companies, thereby understating the total revenues earned by an auditor and overstating the influence of single clients. ${ }^{3}$ Furthermore, including only publicly traded companies leads to a selection bias because the smaller non-listed clients are excluded from the sample. Excluding privately held companies, which are generally smaller than publicly traded companies, reduces the variance of the economic client dependence measure. Hence, a lack of small clients may explain why prior studies did not find an effect of auditor-client economic bonding on earnings management.

Second, as opposed to publicly traded companies which generally face pressure to manage earnings upwards, privately held companies may have incentives to reduce reported earnings (e.g. to minimize taxes by reducing taxable income). In combination with a low litigious environment and examination of the financial statements by the tax authorities, this provides further insight into how public oversight influences audit quality.

Finally, this study measures auditor-client economic bonding at three levels of decision making. Whereas most studies have only examined economic bonding at the audit firm level, or at the audit firm and the local practice office level, this study also considers the effect of economic dependence on clients at the audit partner level. One other study which incorporates auditor-client economic bonding measured at the audit partner 
is a working paper by Coulton and Ruddock (2007). They argue that using this level of analysis leads to a better proxy of the economic bond between auditor and clients, and therefore to more intuitive results. Their study, however, only includes publicly traded companies, while this study includes public as well as private companies.

The remainder of this paper is organized as follows. Section 3.2 discusses relevant prior literature and the hypotheses development. Section 3.3 describes the data selection and outlines the research methodology. Section 3.4 presents the results of the analyses. Finally, section 3.5 provides the conclusion and limitations.

\subsection{Prior literature and hypotheses development}

\subsubsection{Audit quality}

Audit quality is defined by DeAngelo (1981b, p.186) as "the market-assessed joint probability that a given auditor will both (a) discover a breach in the client's accounting system, and (b) report the breach". From this definition follows that audit quality is a function of auditor competence and auditor independence. This paper focuses on the auditor independence component of audit quality. DeAngelo (1981a) and Watts and Zimmerman (1981) define auditor independence as the conditional probability that a discovered breach is reported. This refers to an auditor's ability to withstand client pressure to disclose selectively in the event a breach is discovered (DeAngelo 1981a). An auditor who lacks independence will be less likely to report a discovered breach, thus reducing audit quality.

Both regulators and researchers in the field of auditing have examined which factors influence auditor independence. The main focus has been on the effects of increased tenure and the provision of various types of nonaudit services on auditor independence. The possible detrimental direct effect of audit fees on independence is however underrepresented (Wallman 1996). The relationship between the audit fees earned from a single client and the total audit fees earned by an auditor becomes important when audit fees differ across clients (DeAngelo 1981b). Auditor independence could be harmed when an auditor receives a significant portion of its revenues from a single client (AICPA 1978, DeAngelo 1981b, Wallman 1996).

The likelihood that an auditor maintains its independence depends on the revenues earned from a client, and the expected costs of an audit failure (Chaney et al. 2003). Increased economic dependence on a single client could create incentives for an auditor to be less strict in constraining earnings management in order to retain the client and its audit fees in the future (AICPA 1978; Commission on Public Trust and Private Enterprise 2003). However, larger clients do not only constitute a greater economic bond than smaller clients, but also pose higher litigation and reputation costs in case of an audit failure (Lys and Watts 1994; Reynolds and Francis 2001). The effect of auditor-client economic bonding on audit quality is therefore unclear. 
Clients may represent a substantial part of a local office's or individual partner's revenues while only a minor part of the total firm's revenues. Thus, dependence issues will manifest themselves more strongly and more directly at these levels compared to the firm level (Wallman 1996). An individual audit partner may also be dependent upon a client for his status within the audit firm. Therefore, following the suggestion by Wallman (1996), Reynolds and Francis (2001) and Coulton and Ruddock (2007), this study considers economic dependence not just at the audit firm level, but also at the local office and the audit partner level.

\subsubsection{The association between auditor-client economic bonding and audit} quality

A number of studies (e.g. Reynolds and Francis 2001; Hunt and Lulseged 2007; Coulton and Ruddock 2007; Coulton et al. 2007; Francis and Yu 2009) have tested whether auditor-client economic bonding affects audit quality. The results are mixed. This section presents an overview of the main studies that have focused on the effect of auditor-client economic bonding on audit quality.

Using a sample of U.S. listed companies, Reynolds and Francis (2001) examine whether economic client dependence at the local office level induces Big $\mathrm{N}$ audit firms to allow larger clients, which constitute stronger economic bonding, more discretion to manage earnings than smaller clients. Contrary to their hypothesis, they find evidence that Big $\mathrm{N}$ audit firms constrain earnings management more for clients on which they are more dependent than for clients on which they are less dependent. They argue that Big $\mathrm{N}$ audit firms are unwilling to compromise their independence due to reputation costs associated with an audit failure.

Chung and Kallapur (2003) also examine the effect of auditor-client economic bonding on audit quality for U.S. listed companies. They find no statistically significant association between absolute abnormal accruals and auditor-client economic bonding.

Evidence from the property casualty insurance industry by Gaver and Paterson (2007) indicates that audit quality is not compromised for clients that constitute higher economic dependence. Consistent with Reynolds and Francis (2001) they find that clients are instead given less leeway to understate reserves when they are economically significant to the local practice office.

Contrary to the findings by Reynolds and Francis (2001), Chung and Kallapur (2003) and Gaver and Paterson (2007), Ahmed et al. (2006) find that there is a significantly positive association between auditor-client economic bonding and (signed) discretionary accruals, but only for clients with weak corporate governance. This suggests that audit quality is compromised for more influential clients with poor corporate governance.

Following prior literature which suggests that Big $N$ and non-Big $N$ auditors differ in regard to audit quality, reputation costs, litigation costs, and client characteristics, Hunt and Lulseged (2007) examine the same question as Reynolds and Francis (2001) for a sample of audits conducted by Non- 
Big N audit firms. Similar to Reynolds and Francis (2001) who used a sample of clients of Big $\mathrm{N}$ audit firms, they find that non-Big $\mathrm{N}$ auditors restrict earnings management more for clients that constitute a stronger economic bond. This finding, however, only holds when economic bonding is proxied by the natural log of client sales, measured at the audit firm and the local office level. They find no effect of economic client dependence on audit quality when using audit fees as a proxy for economic client dependence.

Using data on audits of listed U.S. companies by Big $\mathrm{N}$ audit firms, Francis and Yu (2009) report that increased auditor-client economic bonding at the office level is negatively associated with unsigned accruals. This is consistent with the findings of Reynolds and Francis (2001) and Hunt and Lulseged (2007) and implies that Big N auditors are more conservative for clients that constitute a stronger economic bond. However, they find that high levels of economic bonding are associated with greater abnormal accruals for a subsample of clients that report small profits, suggesting economic dependence on these clients induces Big $\mathrm{N}$ auditors to allow more aggressive accounting. The authors focus on this subsample because there is an increased probability that these companies engage in earnings management as they may face pressure to manage earnings upwards from a small loss to a small profit.

An analysis of earnings response coefficients of listed U.S. companies by Ghosh et al. (2009) reveals that investors perceive audit quality to be impaired when there is a high client importance, measured as the audit fees from a client as a percentage of total revenues of an audit firm. Furthermore, they do not find an association between earnings response coefficients and the non-audit fee ratio, suggesting that investors only perceive high levels of client importance to be a threat to auditor independence, not high non-audit fee ratios.

Findings by $\mathrm{Li}$ (2009) suggest that the effect of auditor-client economic bonding on audit quality depends on the regulatory environment. She finds no effect of client importance, measured using ratios of client audit fee and client total audit fee to local office fee revenues, on the likelihood to issue a going concern opinion prior to the enactment of the Sarbanes-Oxley act. However, she reports that auditors are more likely to issue a going concern opinion post Sarbanes-Oxley. This finding indicates that there is a positive association between client importance and audit quality, but only when the regulatory environment provides incentives for auditors to maintain their independence due to reputation and litigation concerns.

Adding to the literature, Coulton and Ruddock (2007) examine economic bonding at the audit partner level. Using data on Australian audits, they find no evidence that clients that generate a higher portion of an auditor's audit fees, non-audit fees or total fees are more likely to manage earnings. Similar to Reynolds and Francis (2001) and Hunt and Lulseged (2007), they find no evidence that auditors allow more earnings management discretion to clients on which they are more economically dependent.

Based on a sample of clients of non-Big $\mathrm{N}$ audit firms, Coulton et al. (2007) show that higher than expected audit fees are associated with higher positive unexpected accruals. This suggests that non-Big $\mathrm{N}$ auditors allow 
more upward earnings management for clients on which they are economically dependent. These findings are restricted to non-Big $\mathrm{N}$ auditors only, suggesting that Big $\mathrm{N}$ auditors do not allow clients that constitute a stronger economic bond more discretion to manage earnings. However, their measure of unexpected audit fees is calculated at the audit firm level. The difference in auditor-client economic bonding between the local office level and the audit firm level is more distinct for Big $\mathrm{N}$ audit firms than for non-Big $\mathrm{N}$ audit firms (Reynolds and Francis 2001). The lack of results for the Big $\mathrm{N}$ audit firm sample may therefore be due to a lack of focus on the relevant unit of decision making, i.e. the local office or the audit partner. Furthermore, while this study provides evidence that abnormally high audit fees impair auditor independence, it finds no evidence that auditor independence is impaired for large clients that generate high normal (expected) audit fees, even though such an effect is likely to exist (Wallman 1996).

Chen et al. (2010) examine whether client importance influences the propensity of auditors to issue modified audit opinions. Based on a sample of publicly listed companies in China, they report that client importance at the audit partner level, but not at the local office level, impairs audit quality. Furthermore, they report that improvements in the legal and regulatory environment in 2001 caused auditors to become more conservative. After the changes, they find a positive association between the probability that a modified audit opinion is issued and client importance at the partner level. This finding suggests that improvements in investor protection and shareholder litigation reduce the negative effect of auditor-client economic bonding on audit quality.

Using a similar model to Chen et al. (2010), Chi et al. (2010) do not find a significant association between client importance at the audit partner level and audit quality for a sample of both listed and non-listed companies in Taiwan. Furthermore, they find no effect of client importance on the likelihood to issue a going concern opinion or the likelihood to meet or beat earnings targets.

In conclusion, these studies find mixed results on the effect of auditorclient economic bonding on audit quality. A possible reason for these mixed results can be found in the sample selection of these studies. Most of these studies included only listed companies in the construction of client portfolios, omitting non-listed clients. This may cause a bias in the economic dependence measure. The current study tries to overcome this problem using a sample of both listed and non-listed companies. The next section discusses the setting of this study, because the setting influences when an association between auditor-client economic bonding and audit quality can be expected. The hypothesis development is presented in section 3.2.4.

\subsubsection{The Belgian setting}

This section discusses the appropriateness of the current setting, and how client and auditor behavior are influenced by this setting.

The first way in which the setting of the current study differs from that of prior studies is related to the cost of litigation. Most prior studies use data on audits conducted in the United States, whereas the current study uses 
Belgian data. The litigation rate in Europe is lower than in the United States (Gietzmann and Quick 1998, Aerts 2002). Wingate (1997) assigns a litigation index of 4.82 to Belgium, which is comparable to most other European countries, but significantly lower than the litigation index of 15 which is assigned to the United States. Following Chaney et al. (2003), auditors can be expected to be more likely to allow client earning management in a low litigious environment than in a high litigious environment.

Furthermore, the current study makes use of both publicly traded and privately held companies, whereas most prior studies included only public clients. Litigation and reputation costs for the auditor in case of a detected audit failure are generally lower for privately held companies because their financial statements are less scrutinized by investors, financial analysts or regulating authorities of stock exchanges (Chaney et al, 2004; Vander Bauwhede and Willekens 2004). Hence, auditors might be expected to allow more earnings management discretion to privately held companies than to listed companies. Trueman and Titman (1988), Coppens and Peek (2005) and Burgstahler et al. (2006) provide evidence that not only publicly traded companies, but also private firms manage earnings. Examining the role of auditors in earnings management reduction is therefore also relevant in a European setting where only a small percentage of the companies are publicly traded.

Another factor that is relevant for the hypotheses development is the degree of alignment between financial and tax accounting. The probability that an audit failure is detected is higher in high tax alignment countries, such as Belgium, than in low tax alignment countries because the financial statements in high tax alignment countries are relatively more scrutinized by the tax authorities (Van Tendeloo and Vanstraelen 2008). The increased probability that an audit failure is detected in high tax alignment countries results in a higher risk of loss of reputation and regulatory fines for the auditor than in low tax alignment countries. ${ }^{4}$ Auditors in high tax alignment environments can therefore be expected to constrain client earnings management more than in low tax alignment environments.

Hence, on the one hand, the low litigious environment and lower reputation costs compared to the United States may result in Belgian auditors being relatively more likely to acquiesce to client pressure to allow earnings management. Examination of the financial statements by the tax authorities, on the other hand, creates incentives for Belgian auditors to constrain client earnings management (Vander Bauwhede et al. 2003; Van Tendeloo and Vanstraelen 2008). Vander Bauwhede et al. (2003) report that upward earnings management is not constrained in Belgium due to a lack of litigation, but downward earnings management is limited by Big 6 auditors due to fear of tax authorities.

Whether auditor-client economic bonding results in impaired audit quality depends on whether pressure by influential clients to allow earnings management is offset by potential litigation costs, reputation costs and regulatory fines. Since potential litigation costs are low in Belgium, the offsetting effect is a function of reputation concerns and public oversight only. Because the extent of public oversight depends on the type of earnings 
management, this setting enables examining whether reputation concerns are sufficient to offset pressure by individual clients to allow earnings management or whether public oversight is required to ensure that audit quality is not comprised for clients on which auditors are economically dependent.

\subsubsection{Hypotheses development}

Given the mixed findings of prior studies, and the possible lack of results due to sample selection bias, this study follows the theoretical arguments outlined at the beginning of this section for the formulation of the hypotheses. Increased auditor-client economic bonding induces auditors to allow more earnings management discretion to clients on which they have higher economic dependence (AICPA 1978; Commission on Public Trust and Private Enterprise 2003). However, auditors have incentives to act independently because of reputation concerns and litigation costs. Hence, there is tradeoff between economic dependence on the one hand and reputation and litigation costs on the other hand (Reynolds and Francis 2001).

As opposed to settings investigated in prior research in which auditors have incentives to constrain upward earnings management due to litigation and reputation costs, upward earnings management is less scrutinized in Belgium and the cost of litigation is lower. Potential reputation losses and litigation costs associated with upward earnings management by clients are therefore lower in Belgium than in settings used in prior research. Because of reduced reputation concerns and litigation costs auditors have less incentives to constrain upward earnings management by clients. Therefore, auditors are expected to generally allow more influential clients more leeway to manage earnings upwards.

While auditor-client economic bonding is expected to impair audit quality for clients that manage earnings upwards, this is not expected for clients that engage in downward earnings management. Tax authorities are focused on restricting downward earnings management because this lowers the taxable income. The probability that financial misstatements are detected by the tax authorities is therefore higher when clients engage in downward earnings management than when they engage in upward earnings management. This increases potential reputation concerns on the part of the auditor vis-à-vis the tax authorities, and increases the expected cost of allowing misstatements. Therefore, auditor-client economic bonding is expected to have no detrimental effect on audit quality for clients that engage in downward earnings management.

Two different hypotheses are used to test whether auditor-client economic bonding influences audit quality, because the extent to which auditors allow client earnings management is likely to differ depending on whether clients engage in upward or downward earning management. Due to fear of the tax authorities, auditors are more likely to allow upward than downward client earnings management. The first hypothesis relates to clients that engage in upward earnings management. The second hypothesis relates to clients that engage in downward earnings management 
and are therefore more likely to have their financial statements scrutinized by the tax authorities. The first hypothesis is as follows:

Hypothesis 1: Auditor-client economic bonding induces auditors to be more lenient towards clients that engage in income increasing earnings management.

For clients engaging in case of downward earnings management the following is hypothesized:

Hypothesis 2: Auditor-client economic bonding does not induce auditors to be more lenient towards clients that engage in income decreasing earnings management.

Auditor-client economic bonding is more likely to manifest itself at the audit partner level than at the local practice office level or audit firm level. Therefore, the results are expected to be strongest when auditor-client economic bonding is measured at the audit partner level.

\subsection{Methodology}

This section discusses the selection of the sample, and the specification of the model used to test the hypotheses.

\subsubsection{Sample selection}

This study uses data on audits conducted in the Belgian audit market for fiscal year 2006. Data on audits conducted during this fiscal year is used, as it is the most recent year for which both financial and auditor information are available.

The Belgian setting has a number of unique characteristics, which allow testing the hypotheses as stated above. Belgian corporate law requires both public and private companies above a certain size limit to have their financial statements audited by a statutory auditor. Furthermore, all audited financial statements report audit firm and audit partner information. This facilitates the empirical construction of client portfolios at both the audit firm and the audit partner level, incorporating both public and private firms. In addition, het Instituut van de Bedrijfsrevisoren (IBR, the Belgian Institute of Auditors) publishes an annual membership list which contains various types of audit partner information, such as the local-practice office at which an audit partner works. This enables the empirical construction of client portfolios at the office level. ${ }^{5}$

These characteristics of the Belgian audit market and the availability of the required financial data and auditor information allow testing whether economic client dependence has a detrimental effect on audit quality. This enables the current study to make a contribution to the current literature that examines the influence of economic dependence on audit quality. This 
A) Initial Sample

Less: Utilities and Financial Institutions

Less: Subsidiaries

Less: Missing values

Less: More than 1 audit partner

Less: Outliers

Less: Observations within small industries

B) Sample for analyses
20,166

$-1,397$

$-2,809$

$-6,790$

$-595$

$-172$

$-32$

setting allows measuring client portfolios more accurately than prior studies by incorporating both listed and non-listed companies in the client portfolios.

Table 3.1, displayed below, gives an overview of the sample selection. Financial data on audited Belgian companies are collected using the BelFirst database. The initial sample includes 20,166 companies which are audited in 2006. Utilities (four digit NACE industry codes between 4,000 and 4,100 ) and financial institutions (four digit NACE industry codes between 6,500 and 6,720) are excluded from the sample due to their specific audit requirements and circumstances $(n=1,397)$. Furthermore, these industries are highly regulated.To accurately reflect auditor-client economic bonding, subsidiaries $(n=2,809)$ are removed from the sample, while consolidated financial information is used for parent companies. An additional 6,790 observations are removed because of missing financial or auditor information. Companies for which more than one audit partner is indicated are also removed because the relative importance for each of the audit partners is unknown $(n=595)$. Following Carey and Simnett (2006), 172 observations with unstable revenues are removed from the sample. ${ }^{6}$ Finally, 32 observations are removed because there are not enough other observations with the same two digit NACE industry code to estimate the measure of audit quality. This results in a final sample of 8,371 usable observations.

\subsubsection{Model specification}

Prior studies have used various proxies for audit quality, such as the extent of litigation against an auditor (e.g. Palmrose 1988), the propensity to issue a qualified audit report (e.g. Hopwood et al. 1994; Vanstraelen 2000), the frequency of earnings restatements (Raghunandan et al. 2003; Kinney et al. 2004), and the degree of client earnings management (e.g. Francis et al. 1999). Most of the concerns about economic client dependence are focused on the extent to which it influences the degree to which auditors allow client earnings management (e.g. AICPA 1978; Commission on Public Trust and Private Enterprise 2003). This study therefore uses the extent of earnings management to proxy for audit quality. High quality audits are commonly argued to constrain management's choice of accounting procedures which are used to manage earnings (Becker et al. 1998, Francis et al. 1999, Frankel et al. 2002). However, as argued in the current study, high levels of auditor-client economic bonding may increase the likelihood that auditors acquiesce to client pressure to allow earnings management, resulting in lower audit quality. 
Consistent with prior studies which have examined the effect of auditorclient economic bonding on earnings management (e.g. Ashbaugh et al. 2003; Coulton and Ruddock 2007; Coulton et al. 2007) the current study makes use of a performance adjusted cross sectional modified-Jones (1991) model to estimate the extent of discretionary accruals to measure client earnings management to proxy for audit quality. Ashbaugh et al. (2003) and Kothari et al. (2005) demonstrate that controlling for underlying company performance improves the specification of the modified-Jones model (Dechow et al. 1995). Therefore, current year return on assets (ROA) is included to control for client performance. ${ }^{7}$ Following Vander Bauwhede and Willekens (2004) and Coulton and Ruddock (2007), lagged total accruals are included in the model to control for the reversing nature of accruals (e.g. DeFond and Park. 2001). A constant is included in the model to control for any heteroskedasticity that is not alleviated by scaling by total assets and to mitigate any problems related to an omitted size variable (Kothari et al. 2005). Discretionary accruals are equal to the residual of the model $\epsilon_{\mathrm{ijt}}$. The following model is estimated by industry (two-digit NACE code):

$$
\begin{aligned}
& \text { TACC }_{i j t}=\beta_{0}+\beta_{1}\left(\frac{1}{A_{i j t-1}}\right)+\beta_{2}\left(\Delta S A L E S_{i j t}-\Delta R E C_{i j t}\right)+\beta_{3} P P E_{i j t}+ \\
& \beta_{4} R O A_{i j t}+\beta_{5} T A C C_{i j t-1}+\epsilon_{i j t}
\end{aligned}
$$

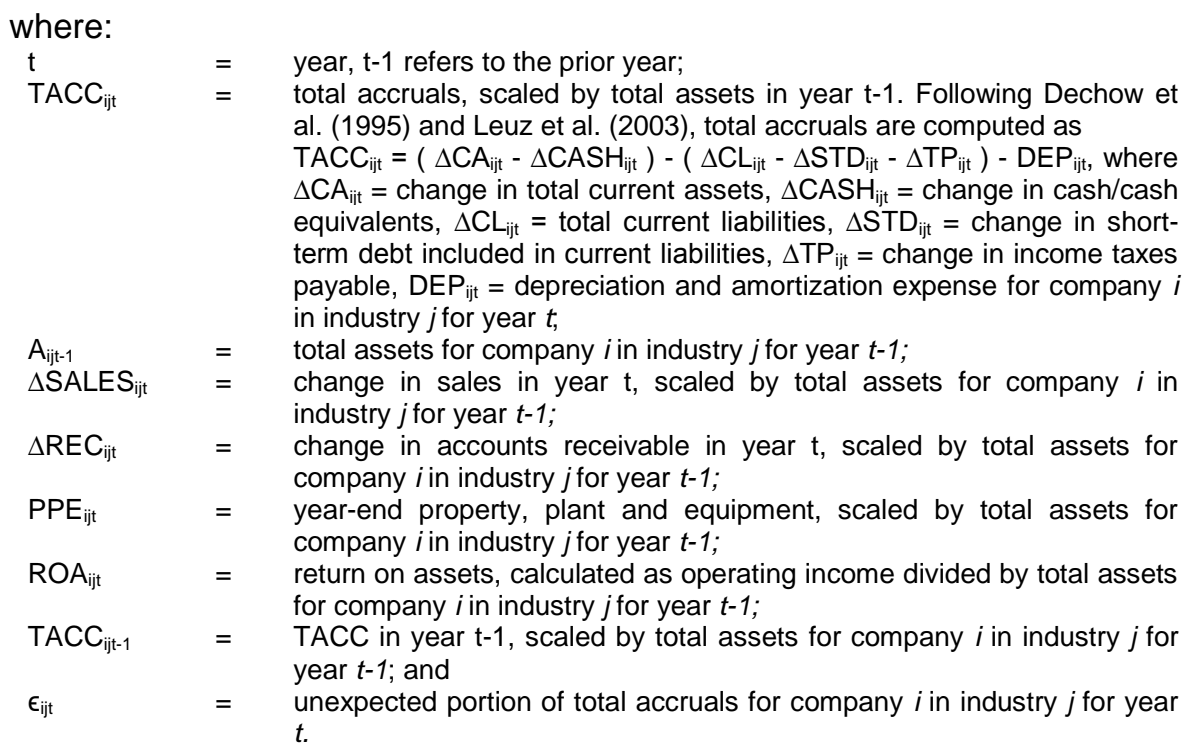

Model (3.2), as stated below, is estimated to test the association between the strength of the auditor-client economic bond and audit quality (as captured by absolute discretionary accruals). The absolute value of discretionary accruals is used to proxy for audit quality because clients can use discretionary accruals to either manage earnings upwards or manage 
earnings downwards. The absolute amount of discretionary accruals is considered to be an appropriate measure of earnings management (Warfield et al. 1995). A higher (lower) amount of absolute discretionary accruals is associated with a greater (lower) degree of earnings management. The model is tested separately for a sample of clients that manage earnings upwards and a sample of clients that manage earnings downwards to enable examining the effect of public oversight on audit quality.

The model, displayed below, is estimated at three different levels: the level of the audit firm, the level of the local practice office, and the level of the audit partner. For each level of decision making, the absolute amount of discretionary accruals is regressed upon a proxy for the auditor-client economic bond measured at that level and a number of control variables. The subsequent section discusses the selection and measurement of the explanatory variables.

$$
\begin{aligned}
& \text { ABSDACC }=\beta_{0}+\beta_{1} E C O N B O N D+\beta_{2} \text { TENURE }<3+ \\
& \beta_{3} \text { TENURE }>7+\beta_{4} M A N D A T E+\beta_{5} P B A N K+\beta_{6} L I S T E D+ \\
& \beta_{7} L N \_A G E+\beta_{8} C F O+\beta_{9} L E V+\beta_{10} G R O W T H+\beta_{11} B I G N+ \\
& \beta_{12} L N_{-} \text {ASSETS }+\beta_{13} L O S S+\in
\end{aligned}
$$

where:

ABSDACC = Absolute value of discretionary accruals scaled by lagged total

ECONBOND = $=$ ECONBOND is computed as the ratio of the natural log of revenues of the client to the sum of the natural log of revenues of all clients of the same auditor. ECONBOND is measured at the audit firm level (ECONBOND_FIRM), the local office level (ECONBOND_OFFICE) or the audit partner level (ECONBOND_PARTNER). This measure is

\begin{tabular}{|c|c|c|}
\hline TENURE $>7$ & $=$ & $\begin{array}{l}1 \text { if the audit partner has been the engagement partner on a client } \\
\text { company for more than } 7 \text { years, and } 0 \text { otherwise; }\end{array}$ \\
\hline MANDATE & $=$ & $\begin{array}{l}1 \text { if the audit is conducted in the last year of the three year renewable } \\
\text { mandate (audit engagement), and } 0 \text { if it is conducted in either of the } \\
\text { first two vears: }\end{array}$ \\
\hline PBANK & $=$ & $\begin{array}{l}1 \text { if the client has a high risk of going bankrupt, based on the } \\
\text { bankruptcy prediction model by Ooghe and Verbaere (1982), and } 0\end{array}$ \\
\hline LISTED & $=$ & $\begin{array}{l}1 \text { if the client is listed on the Belgian stock exchange, and } 0 \\
\text { otherwise; }\end{array}$ \\
\hline LN_AGE & $=$ & natural logarithm of the company age measured in years; \\
\hline CFO & $=$ & $\begin{array}{l}\text { cash flow from operations, scaled by beginning of the year total } \\
\text { assets; }\end{array}$ \\
\hline LEV & $=$ & total liabilities divided by total assets; \\
\hline GROW & $=$ & growth in total assets from the previous to the current fiscal year; \\
\hline BIGN & $=$ & $\begin{array}{l}1 \text { if the client is audited by one of the Big } 4 \text { audit firms, and } 0 \\
\text { otherwise; }\end{array}$ \\
\hline LN_ASSETS & $=$ & $\begin{array}{l}\text { natural logarithm of total assets of the client company }(€ 000) \text { at fiscal } \\
\text { year-end; and }\end{array}$ \\
\hline LOSS & $=$ & $\begin{array}{l}1 \text { if the operating income of the client was negative in the prior fiscal } \\
\text { year, and } 0 \text { otherwise. }\end{array}$ \\
\hline
\end{tabular}
further discussed below;

TENURE $<3=1$ if the audit partner has been the engagement partner on a client company for 2 years or less, and 0 otherwise; 
As audit fee data are not publicly available in Belgium, this study has to rely on a proxy to measure audit fees, and subsequently economic client dependence. Prior literature (e.g. Francis 1984, Moizer and Turley 1987, Craswell et al. 1995, Reynolds and Francis 2001) has reported a high correlation between the natural log of client sales revenues and audit fees. Therefore, this study measures economic client dependence (ECONBOND) as the natural log of the client's revenues divided by the sum of natural log of revenues of all clients belonging to one unit (i.e. audit firm (ECONBOND_FIRM), local office (ECONBOND_OFFICE), and audit partner (ECONBOND_PARTNER). ${ }^{9}$ Prior studies have used similar measures to proxy for client influence (e.g. Reynolds and Francis 2001, Hunt and Lulseged 2007, Francis and Yu 2009). ${ }^{10}$

In addition to the experimental variables, a number of control variables are included based on prior literature (e.g. Reynolds and Francis 2001; Hunt and Lulseged 2007; Carey and Simnett 2006; Coulton and Ruddock 2007; Coulton et al. 2007; Francis and Yu 2009; Knechel and Vanstraelen 2007). First of all, the study controls for tenure (the length of the auditor-client relationship). Audit quality during the first years of the engagement may be relatively lower due to increased economic client dependence as a result of low-balling (DeAngelo, 1981a) or unfamiliarity with the client (e.g. Geiger and Raghunandan 2002; Johnson et al. 2002; Carcello and Nagy 2004; Carey and Simnett 2006). ${ }^{11}$ Long tenure could lead to an erosion of audit quality due to the development of personal relationships between the client and the audit partner or due to a familiarity threat which could impair an auditor's critical appraisal ability (Carey and Simnett 2006). Evidence concerning the effect of long tenure on audit quality is mixed (e.g. Johnson et al. 2002; Myers et al. 2003; Carcello and Nagy 2004; Carey and Simnett 2006; Manry et al. 2008). Audit partner tenure is computed based on the appointment date of the audit partner, which is reported in the Bel-First database. ${ }^{12}$ Two dummy variables are used to distinguish short (less than 3 years) and long tenure (more than 7 years). These cut-offs are consistent with Carey and Simnett (2006). ${ }^{13}$ A positive coefficient for TENURE<3 (partner tenure of less than 3 years) on the amount of absolute discretionary accruals is expected. The effect of TENURE $>7$ (partner tenure of more than 7 years) on audit quality is unclear.

Audits in Belgium are assigned to audit firms based on three year renewable contracts, referred to as a mandates. Because of this, it is possible that auditors become more lenient towards the client in the final year of the engagement, hoping to retain the client for another three years, resulting in higher absolute discretionary accruals (Vanstraelen 2000). ${ }^{14}$ The variable MANDATE indicates whether an audit is conducted in the last year of the three year contract. MANDATE is computed based on the audit firm appointment date reported in the Bel-First database. ${ }^{15}$ MANDATE is expected to have a positive coefficient. ${ }^{16}$

The next control variable, LISTED, indicates whether a company is listed on the Belgian stock exchange. Publicly traded firms have incentives to manage earnings in order to meet or beat earnings targets or analyst forecasts (Beatty et al. 2002; Fischer and Stocken 2004). Besides that, 
ownership is more concentrated in privately held firms, resulting in lower agency costs for privately held companies than for publicly traded companies, making private companies less likely to manage earnings (Fama and Jensen 1983). However, agency problems may still be present for private firms between bankers and shareholders, and bankers and management (Dye, 1988; Vander Bauwhede et al. 2003; Vander Bauwhede and Willekens, 2004). Furthermore, financial statements of privately held firms are more likely to be influenced by tax reduction incentives (Vander Bauwhede and Willekens 2004; Ball and Shivakumar (2005). Potential litigation costs and reputation losses are larger for listed companies, creating an incentive for auditors to constrain earnings management more for listed companies (Chaney et al, 2004; Vander Bauwhede and Willekens 2004). Evidence about differences in earnings management between public and private companies is mixed. Using data on the US banking industry, Beatty et al. (2002) on the one hand show that public companies engage more in earnings management than privately held companies. Vander Bauwhede et al. (2003), on the other hand, show that listed firms engage less in earnings management than non listed firms. This is also found by Burgstahler et al. (2006) who show that capital markets increase earnings informativeness. The effect of LISTED on absolute discretionary accruals is therefore not directly obvious. Therefore, no expectation is formed regarding the sign of LISTED.

Cash flow from operations (scaled by total assets) is included because accruals and cash flows are on average negatively correlated (Dechow 1994; Sloan 1996). Hence, CFO is expected to be negatively associated with discretionary accruals.

Companies with high debt levels have incentives to use accruals to manage earnings upwards in order to meet debt covenants (DeFond and Jiambalvo 1994). High leverage is also related to the risk of default (Ohlson 1980; Beneish and Press 1995). Financially distressed companies have stronger incentives to manage earnings upwards to avoid liquidation (Reynolds and Francis 2001). However, distressed companies engaged in contractual renegotiations with lenders, unions, government, and/or management have incentives to manage earnings downwards. Asset writeoffs and reduced dividends can help management to signal to lenders that they are committed to streamlining operations (DeAngelo et al. 1994). Losses and dividend reductions can be used to convince unions about the need for wage concessions (Liberty and Zimmerman 1986; DeAngelo and DeAngelo 1991). The effects of client leverage and bankruptcy risk on discretionary accruals are therefore unclear. Bankruptcy risk is measured using the dummy variable PBANK. A value of $1(0)$ for PBANK indicates a high (low) bankruptcy risk. Client leverage (LEV) is measured as total liabilities divided by total assets.

Accruals are likely to be positively associated with a company's growth opportunities (Johnson et al. 2002). Consistent with prior studies (e.g. Carey and Simnett 2006; Hunt and Lulseged 2007), this study controls for growth opportunities using the change in total assets (GROWTH). 
Prior literature has shown that the amount of accruals is dependent upon company age (Anthony and Ramesh 1992). Younger companies are more likely to experience financial distress (Carey and Simnett 2006), increasing the pressure to manage earnings. Company age (LN_AGE) is computed as the natural logarithm of the number of years since the formation of the company. A negative association between LN_AGE and the amount of absolute discretionary accruals is expected.

Audit firm size is proxied by a dummy variable, BIGN, which indicates whether the audit firm is one of the Big $\mathrm{N}$ audit firms. ${ }^{17} \mathrm{Big} \mathrm{N}$ audit firms are generally expected to deliver higher quality audits than non-Big $\mathrm{N}$ audit firms (DeAngelo 1981b). This argument is supported by prior studies conducted in the United States which show that Big N audit firms are less likely to allow earnings management by clients (e.g. Becker et al. 1998; Francis et al. 1999; Francis and Krishnan 1999). Evidence on audit-quality differentiation in the European private client segment is however mixed (Vander Bauwhede et al. 2003; Vander Bauwhede and Willekens 2004; Van Tendeloo and Vanstraelen 2008). Consistent with the theoretical argument by DeAngelo (1981b), a negative effect of BIGN on absolute discretionary accruals is expected.

Company size is found to be correlated with operating characteristics which cause large firms to have lower absolute amounts of discretionary accruals (Reynolds and Francis 2001). Company size is measured as the natural log of total assets (LN_ASSETS). A negative association between LN_ASSETS and the magnitude of absolute discretionary accruals is expected.

Finally, consistent with Frankel et al. (2002) and Carey and Simnett (2006), a dummy variable is included which measures whether a company incurred a loss in the prior fiscal year (LOSS). Brown (2001) finds that companies which report losses are less likely to report earnings surprises. A negative association between loss and discretionary accruals is expected.

\subsection{Descriptive statistics and results}

This section provides an overview of descriptive statistics and discusses the results of the tests of the hypotheses.

\subsubsection{Descriptive statistics}

Table 3.2 provides winsorized descriptive statistics on the sample of 8,371 observations ${ }^{18}$. Panel $A$ shows that the absolute discretionary accruals (ABSDACC) are on average 12 percent of lagged total assets. The mean of auditor-client economic bonding is 3.1 percent at the firm level (ECONBOND_FIRM), 5.3 percent at the office level (ECONBOND_OFFICE), and 7.4 percent at the partner level (ECONBOND_PARTNER). As expected, this shows that independence related problems are more likely to occur at lower levels of decision making within an audit firm. 
Table 3.2 - Panel A: Descriptive statistics $(n=8,371)$

\begin{tabular}{|c|c|c|c|c|c|}
\hline Variables & Mean & Median & Std. Dev. & Minimum & Maximum \\
\hline DACC & -.000 & -.002 & .177 & -.582 & .587 \\
\hline ABSDACC & .120 & .076 & .130 & .000 & .587 \\
\hline ECONBOND_FIRM & .031 & .005 & .060 & .001 & .357 \\
\hline ECONBOND_OFFICE & .053 & .027 & .075 & .002 & .487 \\
\hline ECONBOND_PARTNER & .074 & .043 & .089 & .010 & .548 \\
\hline TENURE $<3$ & .240 & 0 & .427 & 0 & 1 \\
\hline TENURE $>7$ & .322 & 0 & .467 & 0 & 1 \\
\hline MANDATE & .369 & 0 & .483 & 0 & 1 \\
\hline PBANK & .245 & 0 & .430 & 0 & 1 \\
\hline LISTED & .002 & 0 & .039 & 0 & 1 \\
\hline AGE & 24.775 & 20 & 17.292 & 3 & 85 \\
\hline CFO & .099 & .083 & .223 & -.703 & .888 \\
\hline LEV & .626 & .663 & .260 & .032 & 1 \\
\hline GROWTH & 101 & .051 & .323 & -.615 & 1.788 \\
\hline BIGN & .427 & 0 & .495 & 0 & 1 \\
\hline ASSETS & $26,845,080$ & 6,629 & $81,258,190$ & 139,000 & $663,291,000$ \\
\hline LOSS & .051 & 0 & .221 & 0 & 1 \\
\hline \multicolumn{6}{|c|}{ Variables are winsorized at the top and bottom $1 \%}$. \\
\hline $\begin{array}{l}\text { ABSDACC } \\
\text { ECONBOND_FIRM }\end{array}$ & \multicolumn{5}{|c|}{$\begin{array}{l}=\text { absolute amount of discretionary accruals scaled by lagged total assets } \\
=\text { economic bonding of an audit firm to a client, computed as the ratio of the natural log of } \\
\text { revenues of the client to the sum of the natural log of revenues of all clients of the same audit } \\
\text { firm }\end{array}$} \\
\hline ECONBOND_OFFICE & \multicolumn{5}{|c|}{$\begin{array}{l}=\text { economic bonding of a local office to a client, computed as the ratio of the natural log of } \\
\text { revenues of the client to the sum of the revenues of total assets of all clients of the same local } \\
\text { office }\end{array}$} \\
\hline ECONBOND_PARTNER & \multicolumn{5}{|c|}{$\begin{array}{l}=\text { economic bonding of an audit partner to a client, computed as the ratio of the natural log of } \\
\text { revenues of the client to the sum of the natural log of revenues of all clients of the same audit } \\
\text { partner }\end{array}$} \\
\hline TENURE $<3$ & \multicolumn{5}{|c|}{$\begin{array}{l}=1 \text { if the audit partner is the engagement partner on a client company for } 2 \text { years or less, and } 0 \\
\text { otherwise }\end{array}$} \\
\hline TENURE $>7$ & \multicolumn{5}{|c|}{$\begin{array}{l}=1 \text { if the audit partner is the engagement partner on a client company for more than } 7 \text { years, } \\
\text { and } 0 \text { otherwise }\end{array}$} \\
\hline MANDATE & \multicolumn{5}{|c|}{$\begin{array}{l}=1 \text { if the audit is conducted in the last year of the three year renewable mandate (audit } \\
\text { engagement), and } 0 \text { otherwise }\end{array}$} \\
\hline PBANK & \multicolumn{5}{|c|}{$\begin{array}{l}=1 \text { if the client has a high risk of going bankrupt, based on the bankruptcy prediction model by } \\
\text { Ooghe and Verbaere (1982), and } 0 \text { otherwise }\end{array}$} \\
\hline LISTED & \multirow{2}{*}{\multicolumn{5}{|c|}{$=1$ if the client is listed on the Belgian stock exchange, and 0 otherwise }} \\
\hline AGE & & & & & \\
\hline CFO & \multirow{2}{*}{\multicolumn{4}{|c|}{$\begin{array}{l}=\text { cash flow from operations, scaled by beginning of the year total assets } \\
=\text { total liabilities divided by total assets }\end{array}$}} & \\
\hline LEV & & & & & \\
\hline GROWTH & \multicolumn{5}{|c|}{$=$ growth in total assets from the previous to the current fiscal year } \\
\hline BIGN & \multicolumn{5}{|c|}{$=1$ if the client is audited by one of the Big 4 audit firms, and 0 otherwise } \\
\hline ASSETS & \multicolumn{5}{|c|}{$=$ total assets of the client company at fiscal year-end } \\
\hline LOSS & \multicolumn{5}{|c|}{$=1$ if the operating income of the client was negative in the prior fiscal year, and 0 otherwise } \\
\hline
\end{tabular}

The control variables show that $24 \%$ of the companies are audited by the same partner for less than 3 years (TENURE $<3$ ), and $32.2 \%$ of the companies is audited by the same audit partner for over 7 years (TENURE $>7$ ). PBANK has a mean of .245 , meaning that $24.5 \%$ of the companies in the sample have a high risk of going bankrupt. Only $0.2 \%$ of the companies in the sample are listed on the Belgian stock exchange. The average age of companies (AGE) within the sample is just below 25 years. Operating cash flows (CFO) are on average equal to $9.9 \%$ of lagged total assets. Leverage (LEV) is on average 62.6\%. Companies experience on average a $10.1 \%$ growth in total assets (GROWTH). The mean company size (ASSETS) expressed in total assets is 26.85 million Euro. From the clients in the sample, $5.1 \%$ experienced an operating loss in the prior fiscal year (LOSS).

In order to provide additional insight into the sample, Panel B of Table 3.2 compares clients of Big $\mathrm{N}$ audit firms with clients of non-Big $\mathrm{N}$ audit firms. 


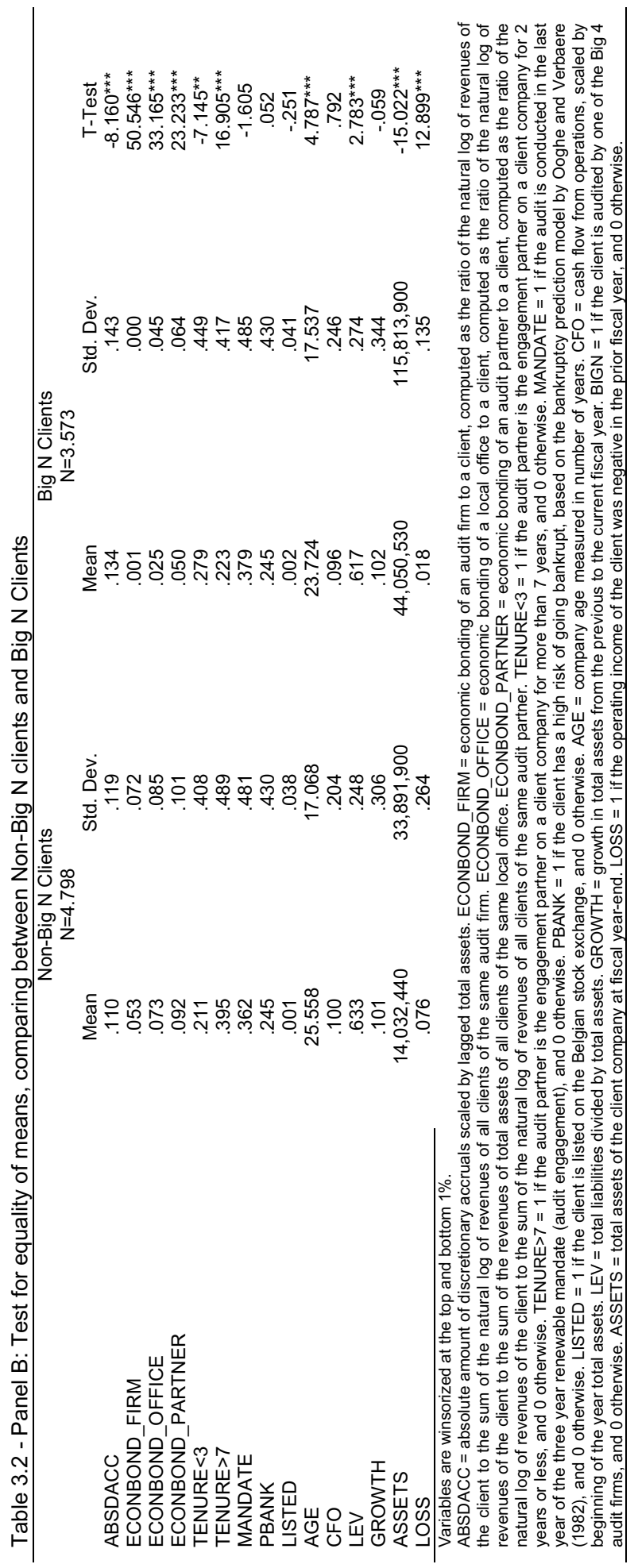


Panel B shows that the economic dependence on individual clients (ECONBOND_FIRM) is significantly larger $(t=50.73)$ larger for non-Big $N$ audit firms (mean=.053) than for Big $\mathrm{N}$ audit firms (mean=.001), as displayed by the difference in means. This finding is as expected, because Big $\mathrm{N}$ audit firms have larger client portfolios than non-Big $\mathrm{N}$ audit firms. Local offices of non-Big $\mathrm{N}$ audit firms are significantly more dependent upon single clients (ECONBOND_OFFICE, mean=.073) than local offices of Big N audit firms (mean=.025). A similar effect is found at the audit partner level, where the mean for ECONBOND_PARTNER is .092 for auditors of non-Big N audit firms and .050 for auditors working for Big N audit firms. Auditor-client economic bonding therefore is more likely to impair auditor independence for non-Big $\mathrm{N}$ auditors than for Big $\mathrm{N}$ auditors.

Furthermore, the table shows that clients of Big $\mathrm{N}$ audit firms differ from clients of non-Big $\mathrm{N}$ audit firms on various other characteristics. Clients of Big $\mathrm{N}$ audit firms have on average more discretionary accruals (ABSDACC; mean=.134) than clients of non-Big $N$ audit firms (.110), which could indicate that Big $\mathrm{N}$ auditors allow their clients more discretion to manage earnings than do non-Big $\mathrm{N}$ auditors.

The clients of Big $\mathrm{N}$ audit firms (23.72 years) are on average younger (AGE) than those of non-Big $n$ audit firms (25.56 years), and the tenure of Big $\mathrm{N}$ audit firms is on average lower (following the scores on the dummy variables TENURE $<3$ and TENURE $>7$ ). On average, the leverage (LEV) of clients of Non-Big N audit firms (.633) is higher than for clients of Big N audit firms (.617). Clients of Big N audit firms are on average larger (44.05 million Euros) than clients of non-Big $\mathrm{N}$ audit firms (14 million Euros). Finally, clients of big $\mathrm{N}$ audit firms are less likely to have an operating loss in the previous fiscal year (mean=.018) than clients of non-Big N audit firms (mean=.076). Consistent with prior research (e.g. Shu 2000), clients of Big N audit firms appear to be less risky than clients of non-Big N audit firms. Clients of Big N audit firms do not significantly differ from clients of non-Big $\mathrm{N}$ audit firms with respect to MANDATE, PBANK, LISTED, CFO and GROWTH.

The correlation matrix is displayed in Table 3.3. The auditor-client economic bonding variables (ECONBOND_FIRM, ECONBOND_OFFICE, and ECONBOND_PARTNER) are significantly and positively correlated with each other (ranging between a minimum correlation of .652 and a maximum correlation of .803). This is however not a cause of concern for the regression analyses since each time only one of these variables is included in the model. The size of correlations among the remaining explanatory variables does not raise concerns related to multicollinearity. ${ }^{19}$

\subsubsection{Multivariate results}

Table 3.4 presents the results of the multivariate regressions using absolute discretionary accruals as a proxy for audit quality. A higher value of discretionary accruals indicates lower audit quality. To test hypotheses 1 and 2 , the sample is split into two subsamples. The first subsample consists of clients with upward earnings management. The other subsample consists of clients engaging in downward earnings management. For ease of inter- 


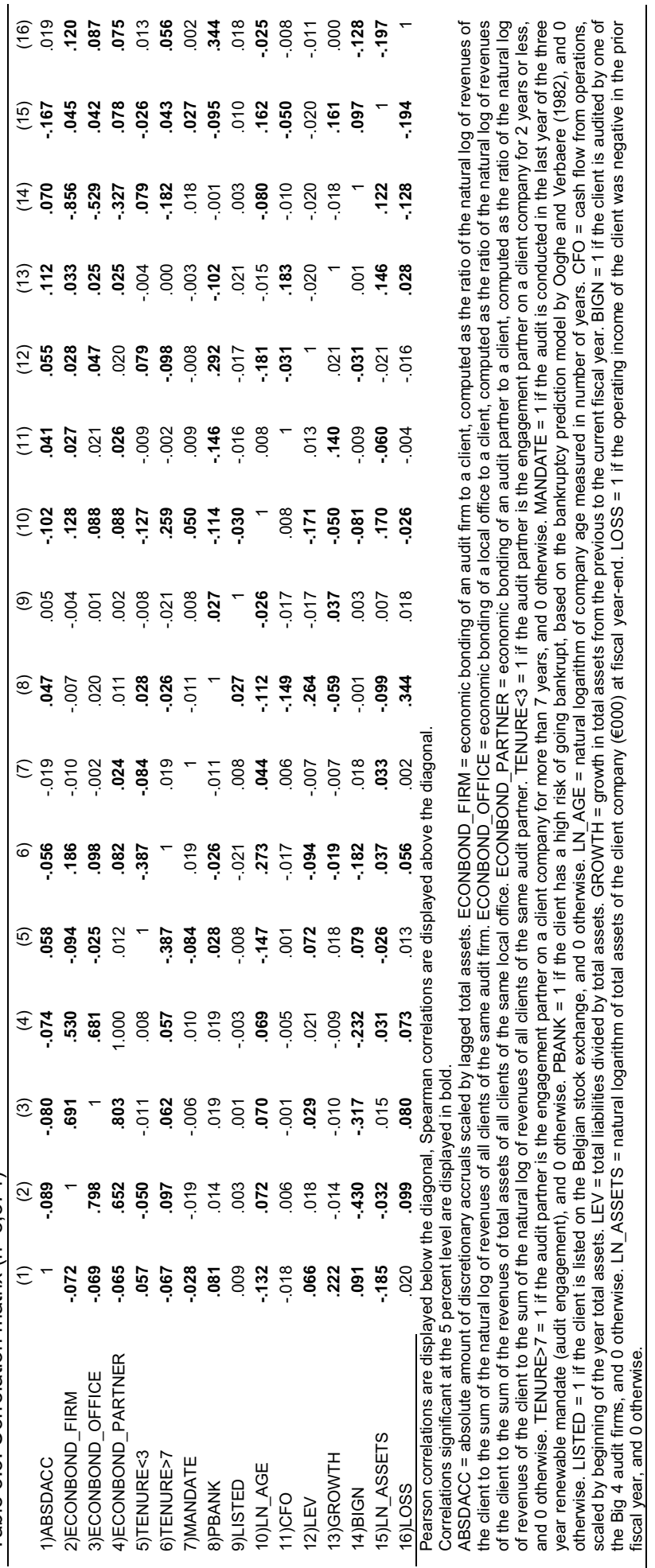




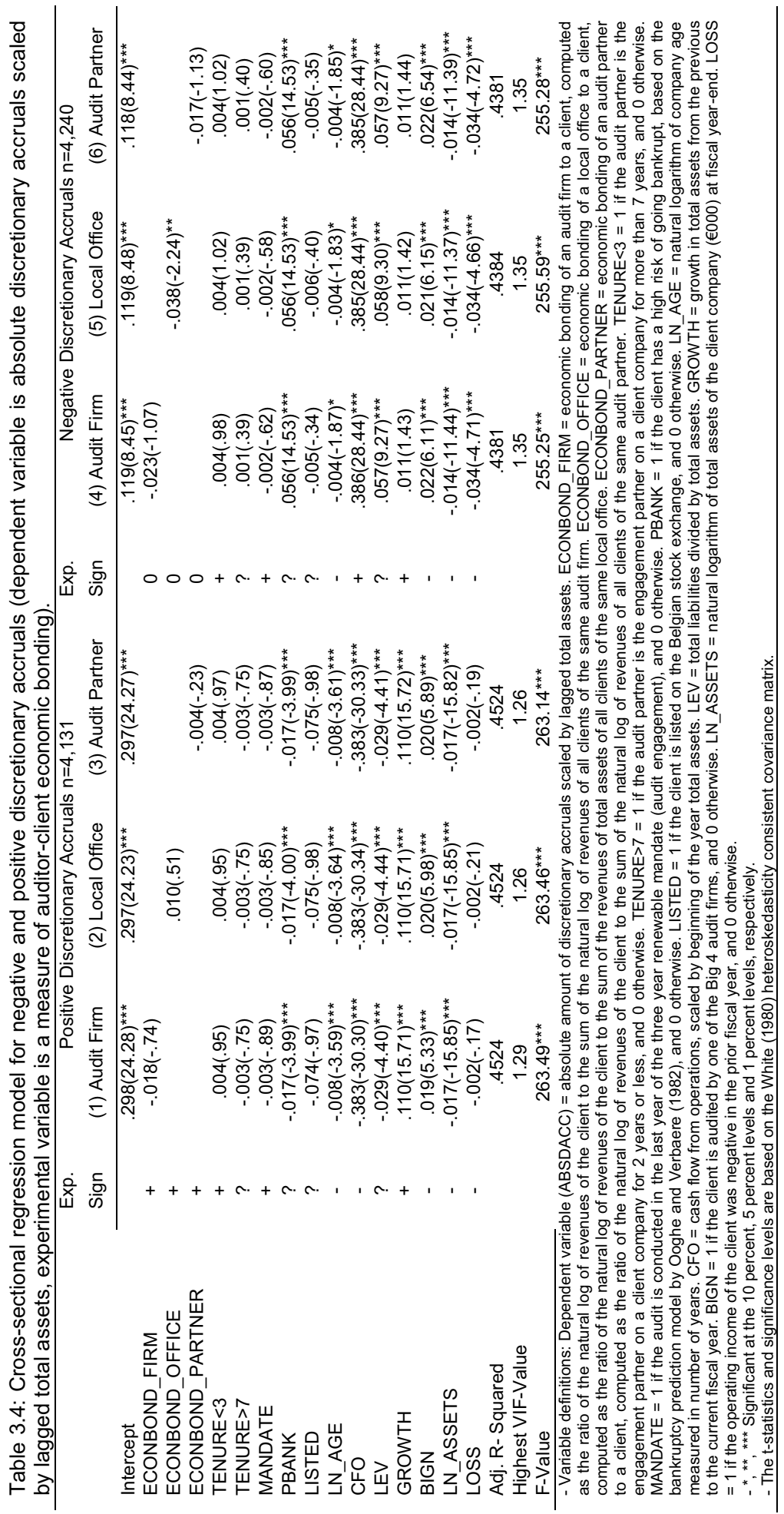


pretation, absolute discretionary accruals are used as the dependent variable for both subsamples. Higher absolute discretionary accruals indicate greater client earnings management and lower audit quality. Separate regressions are ran for the audit firm level (ECONBOND_FIRM), the local practice office level (ECONBOND_OFFICE) and the audit partner level (ECONBOND_PARTNER). The White test rejects the hypothesis that the residuals of the models are homoscedastic (White 1980). To control for heteroskedasticity, White-corrected standard errors are reported.

The results for the subsample of clients with positive discretionary accruals, columns 1-3, show that the coefficients for ECONBOND_FIRM $(\beta=-.018, \quad p>.10)$ and ECONBOND_PARTNER $(\beta=-.004, p>.10)$ are negative, while the coefficient of ECONBOND_OFFICE $(\beta=.10, p>.10)$ is positive. All coefficients are insignificant, which suggests that auditors do not give in to pressure from clients with a strong economic bond to allow more earnings management, nor do they constrain earnings management more than for less influential clients. However, auditors also do not constrain earnings management more for clients with a strong economic bond than for clients with a weak economic bond. Hence, auditor-client economic bonding does not appear to have an effect on audit quality. Hypothesis 1 is therefore not supported. Results for the subsample of clients with negative discretionary accruals are displayed in columns 4-6 of Table 3.4. The coefficient for ECONBOND is negative for each of the three levels, but only significant at the local office level (ECONBOND_OFFICE; $\beta=-.038, p<.05$ ). This suggests that auditors do not allow clients with a greater economic bond more room to manage earnings downwards. This finding is consistent with Hypothesis 2, which states that auditors do not acquiesce to client pressure to manage earnings downwards. Instead, auditors constrain downward earnings management for clients for which economic bonding at the local office is stronger.

The coefficients for the control variables and their significance levels are consistent across all three levels of decision making within audit firms. For the sake of brevity, the discussion is limited to the audit partner level. The coefficients on TENURE<3 $(\beta=.004, p>.10)$ and TENURE $>7(\beta=-.003, p>.10)$ are insignificant for the positive discretionary accruals subsample. Hence the length of the auditor-client relationship does not appear to have an effect on audit quality. For the sample with income decreasing accruals, the coefficients for both measures of tenure, TENURE $<3(\beta=.004 ; p>.10)$ and TENURE>7 $(\beta=.001 ; p>0.10)$ are positive but insignificant.

Contrary to the expectation, but consistent with Vanstraelen (2000), MANDATE has a negative, but insignificant coefficient for the positive discretionary accruals sample $(\beta=-.003, p>.10)$ and the negative discretionary accruals sample $(\beta=.-002 ; p>.10)$. This suggests that auditors do not allow more earnings management in the last year of the renewable mandate in order to increase the probability of a renewal of the engagement. $^{20}$

Companies which are in financial distress (PBANK) have smaller positive discretionary accruals $(\beta=-.383, p<.01)$ and larger negative discretionary accruals $(\beta=.056 ; p<.01)$. This is consistent with the argumentation by 
DeAngelo et al. (1994) that companies in financial distress have incentives to manage earnings downwards to either signal their commitment to reorganizations or to convince unions about the necessity of wage reductions.

Publicly traded companies (LISTED) do not appear to differ from nonlisted companies with respect to the amount of either positive discretionary accruals $(\beta=.-075 ; p>.10)$ or negative discretionary accruals $(\beta=.-005$; $\mathrm{p}>$.10).

The coefficient for company age (LN_AGE) is significantly negative for both samples $(\beta=-.008, p<.01, \beta=.-004 ; p<.10)$. This suggests that older companies engage less in earnings management than younger companies. Hence, audit quality seems to be positively related with client age.

Cash flows from operations (CFO) are negatively associated $(\beta=-.383$, $p<.01)$ with positive discretionary accruals, and positively associated with negative discretionary accruals $(\beta=.385, \quad p<.01)$, which shows that companies with higher cash flows from operations have lower signed discretionary accruals, consistent with findings from prior literature (e.g. Frankel et al. 2002).

More highly leveraged firms (LEVERAGE) have smaller positive discretionary accruals $(\beta=-.018, p>.10)$ and larger negative discretionary accruals $(\beta=.057, p<0.01)$ which suggests that companies with higher leverage have lower (signed) discretionary accruals, consistent with findings by prior studies (e.g. Hunt and Lulseged 2007).

The coefficient of asset growth (GROWTH) for the subsample of clients with positive discretionary accruals is significantly positive $(\beta=.110, p<.01)$. The effect of asset growth on the amount of negative discretionary accruals is insignificant $(\beta=.011, p>.10)$. Hence, there is evidence that faster growing companies have incentives to manage earnings upwards, but not downwards. Prior studies either found no effect of growth on discretionary accruals (e.g. Carey and Simnett 2006) or a positive effect on both positive and negative discretionary accruals (e.g. Hunt and Lulseged 2007).

Contrary to the expectations, Big $\mathrm{N}$ audit firms seem to allow their clients more upwards $(\beta=.020, p<0.01)$ and downwards $(\beta=.022, p<0.01)$ earnings management discretion than non-Big $\mathrm{N}$ audit firms. This finding is in line with other European studies which show mixed results regarding audit-quality differentiation in the European private client segment (Vander Bauwhede et al. 2003; Vander Bauwhede and Willekens 2004; Van Tendeloo and Vanstraelen 2008).

Size (LN_ASSETS) has a negative association with the amount of positive discretionary accruals $(\beta=-.017, \quad p<0.01)$. The coefficient of LN_ASSETS for the negative discretionary accruals sample is negative $(\beta=-$ $.014, p<0.01)$. Consistent with Carey and Simnett (2006), this result shows that the degree of earnings management is relatively lower for larger companies than for smaller clients. Hence, audit quality is positively associated with client size.

Finally, the coefficient of LOSS is negative, but insignificant $(\beta=-.002$, $p>10$ ) for the sample of clients with positive discretionary accruals. Hence, no effect is found for clients that reported a loss in the prior fiscal year and 
manage earnings upwards in the current year. The effect of LOSS on the absolute amount of discretionary accruals is negative and significant $(\beta=$ $-.034, p<.01)$ for the sample of clients that engage in income decreasing earnings management. Hence, audit quality is higher for clients that reported a loss in the previous year and manage earnings downwards in the current year.

\subsubsection{Strong versus weak economic bonding}

A possible explanation for the general lack of significance of ECONBOND is the correlation of this variable with client portfolio size. The large variation in client portfolio size across audit firms makes it unlikely for this measure to pick up the effect of influential clients in larger portfolios. While a client is more likely to induce economic dependence when the client portfolio is small, it is still possible for an auditor with a large portfolio to be economically dependent upon a single client (Francis and Yu 2009). Therefore, a new variable (HIGH_ECONBOND) is constructed which measures whether a client is larger or smaller than the median client within a portfolio. This dummy variable has a value of 1 if a client is relatively large given an auditor's portfolio (above median ECONBOND), and 0 otherwise. This variable is measured at the audit firm level (HIGH_ECONBOND_FIRM), the local office level (HIGH_ECONBOND_OFFICE), and the audit partner level (HIGH_ECONBOND_PARTNER).

To test whether the amount of discretionary accruals is related to HIGH_ECONBOND, the following model is estimated:

ABSDACC $=\beta_{0}+\beta_{1}$ HIGH_ECONBOND $+\beta_{2}$ TENURE $<3+$ $\beta_{3}$ TENURE $>7+\beta_{4}$ MANDATE $+\beta_{5}$ PBANK $+\beta_{6}$ LISTED + $\beta_{7} L N \_A G E+\beta_{8} C F O+\beta_{9} L E V+\beta_{10}$ GROWTH $+\beta_{11} B I G N+$ $\beta_{12} L N \_A S S E T S+\beta_{13} L O S S+\epsilon$

where:

HIGH_ECONBOND $=1$ if there is a strong economic bond between the auditor and the client, and 0 otherwise. HIGH_ECONBOND is measured at the audit firm level (HIGH_ECONBOND_FIRM), the local office level (HIGH_ECONBOND_OFFICE) or the audit partner level (HIGH_ECONBOND_PARTNER).

The other variables are defined as earlier.

Results of the model estimating economic client dependence using a dummy variable based on the relative economic bonding of a client within an auditor's portfolio are displayed in Table 3.5.

The coefficients for HIGH_ECONBOND for the subsample of clients with positive discretionary accruals (columns 1-3) are positive and significant at the audit firm level (HIGH_ECONBOND_FIRM; $\beta=.021, p<0.01$ ), the local office level (HIGH_ECONBOND_OFFICE; $\beta=.021, p<0.01$, ) and the audit partner level (HIGH_ECONBOND_FIRM; $\beta=.021, p<0.01$ ). This provides evidence in support of hypothesis 1 that auditors acquiesce to client pres- 


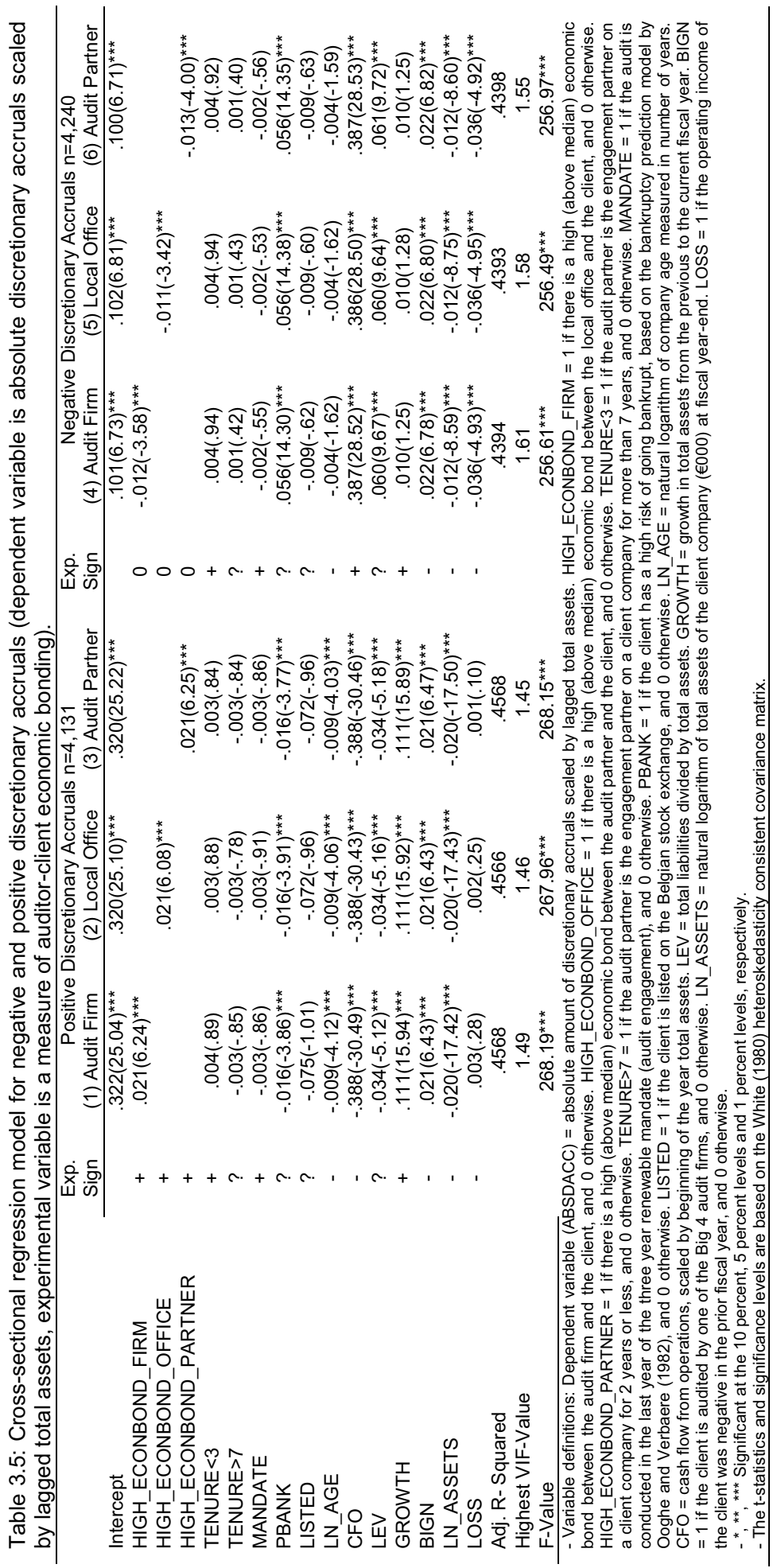


sure by large clients to allow upward earnings management. Hence, auditors seem to compromise audit quality for clients engaging in upward earnings management if they are economically dependent on these clients. Reputation concerns therefore appear to be insufficient to offset the detrimental effect of auditor-client economic bonding on audit quality.

Columns 4-6 display the results for the subsample of clients with negative discretionary accruals. The coefficients for HIGH_ECONBOND_FIRM ( $\beta=$ -.012, $p<0.01), \quad$ HIGH_ECONBOND_OFFICE $\quad(\beta=-.011, \quad p<0.01)$ and HIGH_ECONBOND_PARTNER $(\beta=-.013, \quad p<0.01)$ are all significantly negative. Consistent with hypothesis 2 , this suggests that auditors do not allow clients with which they have a stronger economic bond more discretion to manage earnings downwards. In fact, audit quality is higher for clients on which auditors are economically dependent. This finding suggests that auditors do not compromise audit quality for clients on which they are economically dependent if public oversight is present.

The results for the control variables are consistent with those reported in Table 3.4, with the exception of the coefficient for LN_AGE in the negative discretionary accruals subsample, which is no longer significant $(\beta=$ $-.004, p>0.10)$.

\subsubsection{Summary of results}

The previous analyses show that the results are dependent upon the measure of economic bonding. ECONBOND, the measure used by Reynolds and Francis (2001) and Hunt and Lulseged (2007), only provides evidence of a relationship between auditor-client economic bonding at the local practice office for a subsample of companies engaging in downward earnings management. This measure is however dependent upon portfolio size, and therefore unlikely to pick up the effect of influential clients in large portfolios. To acknowledge that single clients can create an economic bond in large client portfolios (e.g. Francis and Yu 2009) an alternative measure of client-economic bonding is used, which classifies clients as either large or small within an auditor's portfolio. The results for this measure, HIGH_ECONBOND, show that auditors allow clients to which they have higher economic dependence more discretion to manage earnings upwards. The coefficient for HIGH_ECONBOND is significantly positive in the sample with positive discretionary accruals irrespective of whether client economic bonding is measured at the audit firm, the local practice office level or the audit partner level. This provides evidence in support of Hypothesis 1. Consistent with hypothesis 2, a negative association is found between auditor-client economic bonding and the amount of discretionary accruals. Hence, auditors constrain earnings management more for clients on which they are economically dependent. These findings are consistent with the argumentation that auditors constrain downward earnings management due to a fear that tax authorities discover any irregularities (Vander Bauwhede et al. 2003). Hence, reputation concerns alone are not sufficient for auditors to resist pressure from clients to allow earnings management. Public oversight 
therefore appears to be necessary to mitigate the detrimental effect of auditor-client economic bonding on audit quality.

\subsubsection{Robustness checks}

A number of robustness checks are conducted to examine the sensitivity of the results to alternative specifications and sample selection criteria.

\subsubsection{Auditor type}

Coulton and Ruddock (2007) find that any evidence of a detrimental effect of auditor-client economic bonding on auditor independence is restricted to cases where the auditor is a non-Big $\mathrm{N}$ auditor. A possible explanation for this finding is that the potential cost of an audit failure is higher for Big $\mathrm{N}$ audit firms than for non-Big $\mathrm{N}$ audit firms, which creates incentives for Big $\mathrm{N}$ auditors to further constrain client earnings management. To examine whether the results reported in the previous section are dependent upon auditor type, regression model (3.3) is estimated separately for Big N audit firms and Non-Big N audit firms, reported respectively in Table 3.6 and Table 3.7. For these regressions, the dichotomous measure of economic bonding, HIGH_ECONBOND, is used because this variable is likely to be a better measure of economic bonding than the continuous variable ECONBOND. As explained in section 4.3 , the continuous variable may not pick up the effect of economic bonding due to the large variation in client portfolio size (see section 3.4.3).

The results in Tables 3.6 and 3.7 are consistent with those reported in Table 3.5. For the subsample of clients with positive discretionary accruals, the coefficients on HIGH_ECONBOND_FIRM, HIGH_ECONBOND_OFFICE and HIGH_ECONBOND_PARTNER are positive and significant, for both Big $\mathrm{N}$ and non-Big $\mathrm{N}$ audit firms. For the subsample of clients with negative discretionary accruals, the coefficients of HIGH_ECONBOND_FIRM, HIGH_ECONBOND_OFFICE and HIGH_ECONBOND_PARTNER are significantly negative, also for both the Big $\bar{N}$ and the Non-Big $N$ samples. Therefore, it can be concluded that the results hold for both Big $N$ and nonBig $\mathrm{N}$ audit firms. It is possible that audit partners are more concerned with their own pay off than with the reputation of the audit firm, because audit partners receive most of the benefits associated with an audit, while the potential litigation costs and reputation losses are shared with the audit firm.

One noticeable difference from the results reported in Tables 3.4 and 3.5 is that a significantly negative effect is found for TENURE $>7$ in the sample of clients with positive discretionary accruals audited by non-Big $\mathrm{N}$ clients. This indicates that non-Big $\mathrm{N}$ audit quality improves with longer tenure for clients that engage in upward earnings management.

\subsubsection{Quartiles}

As a robustness check to verify whether the results reported for HIGH_ECONBOND are not driven by an arbitrary cut-off at the median client within an audit portfolio, ECONBOND is categorized into quartiles. Four 


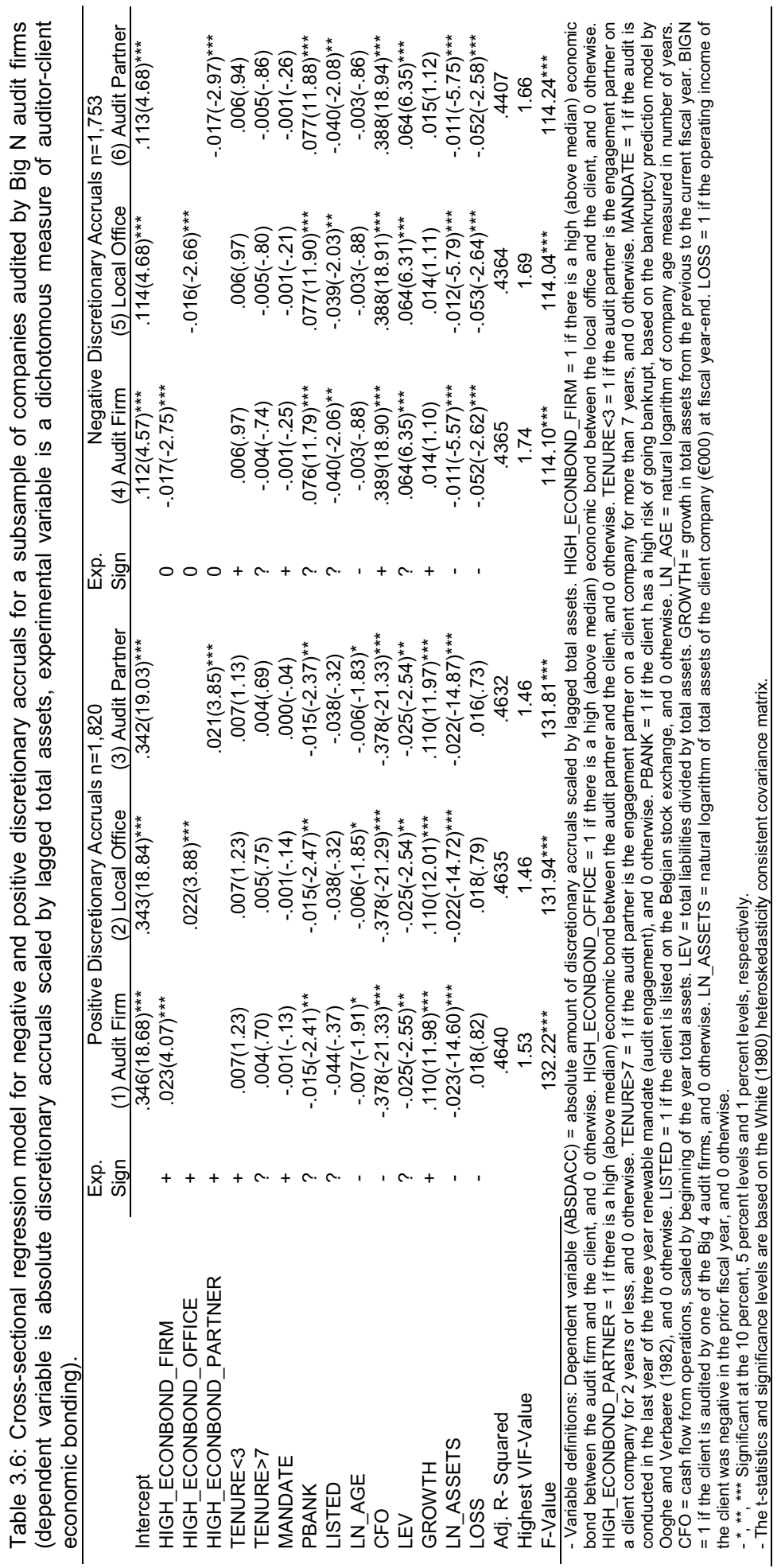




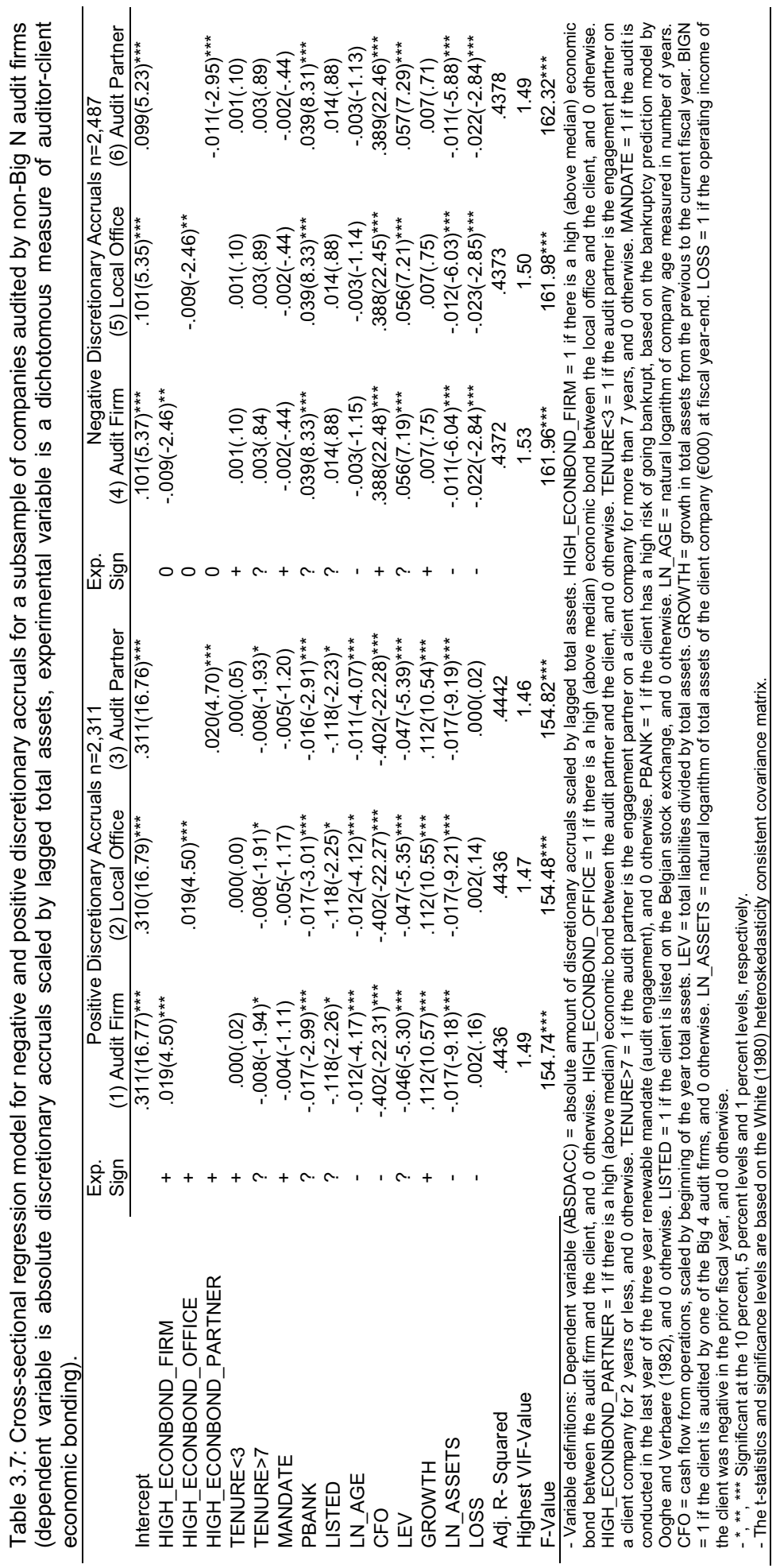


dummy variables per level within an audit firm are used to categorize clients within a portfolio from weak (ECONBOND_Q1) to strong (ECONBOND_Q4) economic bonding. To analyze whether categorizing clients within quartiles affects the results, the following model is estimated: ${ }^{2}$

$$
\begin{aligned}
& A B S D A C C=\beta_{0}+\beta_{1} E C O N B O N D_{-} Q 2+\beta_{2} E C O N B O N D \_Q 3+ \\
& \beta_{3} E C O N B O N D_{-} Q 4+\beta_{4} T E N U R E<3+\beta_{5} T E N U R E>7+ \\
& \beta_{6} M A N D A T E+\beta_{7} P B A N K+\beta_{8} L I S T E D+\beta_{9} L N \_A G E+\beta_{10} C F O+ \\
& \beta_{11} L E V+\beta_{12} \text { GROWTH }+\beta_{13} \text { BIGN }+\beta_{14} L N_{-} \text {ASSETS }+\beta_{15} L O S S+\epsilon
\end{aligned}
$$

\begin{tabular}{|c|c|c|}
\hline ECONBOND_Q2 & $=$ & $\begin{array}{l}1 \text { if the strength of the economic bond between the auditor and } \\
\text { the client is between the } 25^{\text {th }} \text { and } 50^{\text {th }} \text { percentile of all clients } \\
\text { within the auditor's portfolio, and } 0 \text { otherwise. ECONBOND_Q2 } \\
\text { is measured at the audit firm level (ECONBOND_FIRM_Q2), } \\
\text { the local office level (ECONBOND_OFFICE_Q2) and the audit } \\
\text { partner level (ECONBOND_PARTNER_Q2); }\end{array}$ \\
\hline ECONBOND_Q3 & $=$ & $\begin{array}{l}1 \text { if the strength of the economic bond between the auditor and } \\
\text { the client is between the } 50^{\text {th }} \text { and } 75 \text { th }^{\text {th }} \text { percentile of all clients } \\
\text { within the auditor's portfolio, and } 0 \text { otherwise. ECONBOND_Q3 } \\
\text { is measured at the audit firm level (ECONBOND_FIRM_Q3), } \\
\text { the local office level (ECONBOND_OFFICE_Q3) and the audit } \\
\text { partner level (ECONBOND_PARTNER_Q3); and }\end{array}$ \\
\hline ECONBOND_Q4 & $=$ & $\begin{array}{l}1 \text { if the strength of the economic bond between the auditor and } \\
\text { the client is between the } 75^{\text {th }} \text { and } 100^{\text {th }} \text { percentile of all clients } \\
\text { within the auditor's portfolio, and } 0 \text { otherwise. ECONBOND_Q4 } \\
\text { is measured at the audit firm level (ECONBOND_FIRM_Q4), } \\
\text { the local office level (ECONBOND_OFFICE_Q4) and the audit } \\
\text { partner level (ECONBOND_PARTNER_Q4). }\end{array}$ \\
\hline
\end{tabular}

where:

The results of estimating model (3.4) are reported in Table 3.8. The direction of the coefficients is consistent with those reported for HIGH_ECONBOND in Table 3.5. Further tests show that the coefficients also differ significantly between quartiles. This indicates that the results are robust to categorizing auditor-client economic bonding using quartiles instead of medians.

\subsubsection{Abnormal working capital accruals}

Becker et al. (1998) argue that managers have greater discretion with respect to working capital accruals than total accruals. Furthermore, Young (1999) shows that discretionary accruals estimated by the modified Jones model may contain systematic errors when normal accruals are estimated including depreciation. Therefore, as a sensitivity analysis, the effect of auditor-client economic bonding on audit quality is estimated using abnormal working capital accruals as a proxy of audit quality. Abnormal working capital accruals are estimated using a model by Ferguson et al. (2004) and Antle et al. (2006). Consistent with model (3.1), current year return on assets (ROA) are included to control for underlying company performance (Kothari et al. 2005). Lagged working capital accruals is included to control for the 


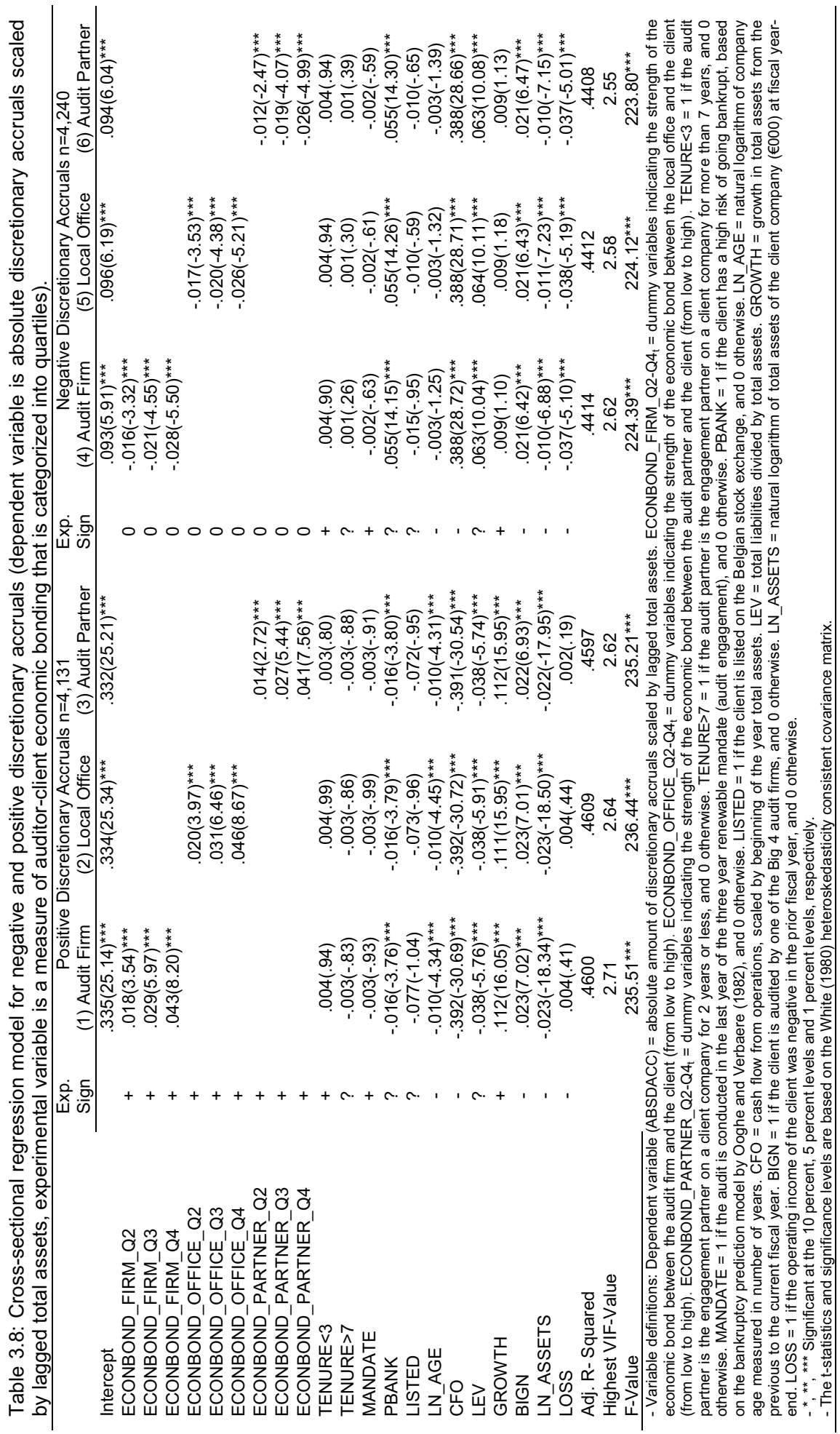


reversing nature of accruals (Vander Bauwhede and Willekens 2004; Coulton and Ruddock 2007). A constant is added to control for heteroskedasticity and to mitigate problems related to an omitted size variable (Kothari et al. 2005). Abnormal working capital accruals are equal to the residual of the model. The following model is estimated by industry (twodigit NACE code):

$$
\begin{aligned}
& W C A_{i j t}=\beta_{0}+\beta_{1}\left(\frac{1}{A_{i j t-1}}\right)+\beta_{2}\left(\Delta S A L E S_{i j t}-\Delta R E C_{i j t}\right)+\beta_{3} R O A_{i j t}+ \\
& \beta_{4} W C A_{i j t-1}+\epsilon_{i j t}
\end{aligned}
$$

where:

$$
\begin{aligned}
& \mathrm{t}=\text { year, } \mathrm{t}-1 \text { refers to the prior year; } \\
& \mathrm{WCA}_{\mathrm{ijt}}=\text { working capital accruals, scaled by lagged total assets. Following } \\
& \text { Ferguson et al. (2004), working capital accruals is computed as } \text { WCA }_{\text {ijt }} \\
& =\left(\Delta \mathrm{CA}_{\mathrm{itt}}-\Delta \mathrm{CASH}_{\mathrm{iti}}\right)-\Delta \mathrm{CL}_{\mathrm{ijt}} \\
& \text { where } \Delta \mathrm{CA}_{\mathrm{ijt}}=\text { change in total current assets, } \Delta \mathrm{CASH}_{\mathrm{ijt}}=\text { change in } \\
& \text { cash/cash equivalents, } \Delta \mathrm{CL}_{\mathrm{ijt}}=\text { total current liabilities for company } i \text { in } \\
& \text { industry } j \text { for year } t \text {; } \\
& \mathrm{A}_{\mathrm{it}-1}=\text { total assets for company } i \text { in industry } j \text { for year } t-1 \text {; } \\
& \triangle \text { SALES }_{\mathrm{ijt}}=\text { change in sales in year } \mathrm{t} \text {, scaled by total assets for company } i \text { in } \\
& \text { industry } j \text { for year } t-1 \text {; } \\
& \Delta \mathrm{REC}_{\mathrm{ijt}}=\text { change in accounts receivable in year } \mathrm{t} \text {, scaled by total assets for } \\
& \mathrm{ROA}_{\mathrm{ijt}}=\quad \begin{array}{l}
\text { company } i \text { in industry } j \text { for year } t-1 \text {; } \\
\text { return on assets, calculated as operating income scaled by total assets }
\end{array} \\
& \text { for company } i \text { in industry } j \text { for year } t-1 \text {; } \\
& \mathrm{WCA}_{\mathrm{jt}-1}=\mathrm{WCA} \text { in year } \mathrm{t}-1 \text {, scaled by total assets for company } i \text { in industry } j \text { for } \\
& \text { year } t-1 \text {; } \\
& \epsilon_{\mathrm{ijt}}=\text { unexpected portion of total accruals for company } i \text { in industry } j \text { for year }
\end{aligned}
$$

The following two models are estimated to examine the effects of the continuous measure of auditor-client (ECONBOND), and the dichotomous measure of auditor-client economic bonding (HIGH_ECONBOND) on the amount of absolute abnormal working capital accruals.

$$
\begin{aligned}
& A B S A W C A=\beta_{0}+\beta_{1} \text { ECONBOND }+\beta_{2} \text { TENURE }<3+ \\
& \beta_{3} \text { TENURE }>7+\beta_{4} \text { MANDATE }+\beta_{5} \text { PBANK }+\beta_{6} \text { LISTED }+ \\
& \beta_{7} L N \_A G E+\beta_{8} C F O+\beta_{9} L E V+\beta_{10} \text { GROWTH }+\beta_{11} B I G N+ \\
& \beta_{12} L N_{-} \_ \text {ASSETS }+\beta_{13} L O S S+\epsilon \\
& A B S A W C A=\beta_{0}+\beta_{1} \text { HIGH_ECONBOND }+\beta_{2} \text { TENURE }<3+ \\
& \beta_{3} \text { TENURE }>7+\beta_{4} \text { MANDATE }+\beta_{5} \text { PBANK }+\beta_{6} \text { LISTED }+ \\
& \beta_{7} L N \_A G E+\beta_{8} C F O+\beta_{9} L E V+\beta_{10} G R O W T H+\beta_{11} B I G N+ \\
& \beta_{12} L N_{-} A S S E T S+\beta_{13} L O S S+\epsilon
\end{aligned}
$$

where:

ABSAWCA $=$ Absolute value of abnormal working capital accruals scaled by lagged total assets.

The other variables are defined as earlier. 
The estimations of models (3.6) and (3.7) are shown in Table 3.9 and Table 3.10, respectively. The results are generally in line with those shown earlier. ECONBOND has no significant effect on the amount of income increasing abnormal working capital accruals, irrespective of whether auditor-client economic bond is measured at the audit firm level $(\beta=-.025$, $p>.10)$, the local office level $(\beta=-.002, p>.10)$ or the audit partner level $(\beta=-$ $.016, p>.10)$. The coefficient for ECONBOND_FIRM for the sample of companies engaging in income decreasing abnormal working capital accruals is negative and significant $(\beta=-.042, p<.10)$. ECONBOND no longer has a significant association with income decreasing working capital accruals when measured at the local office $(\beta=-.020, p>.10)$. The coefficient for ECONBOND measured at the audit partner level is also insignificant $(\beta=-$ $.012, p>.10)$. Hence, only weak evidence of an effect of economic client dependence on audit quality are found when audit quality, proxied by abnormal working capital accruals, is regressed upon a continuous measure of auditor-client economic bonding.

Table 3.10 shows that the coefficients HIGH_ECONBOND_FIRM $(\beta=.011, \quad p<.01), \quad$ HIGH_ECONBOND_OFFICE $\quad(\beta=.01, \quad p<.01)$ and HIGH_ECONBOND_PARTNER $(\beta=.013, p<.01)$ are positive and significant for each of the three levels in the positive abnormal working capital accruals sample. The coefficients for HIGH_ECONBOND are negative and significant across each of the three levels, HIGH_ECONBOND_FIRM $(\beta=-.018, p<.01)$ HIGH_ECONBOND_OFFICE $(\beta=-.01 \overline{6}, \quad p<.01)$ and HIGH_ECONBOND_ PARTNER $(\beta=-.01 \overline{7}, \quad \mathrm{p}<.01)$, in the negative abnormal working capital accruals sample. These results are consistent with the results reported in Table 3.5 and suggest that auditors allow more discretion to manage earnings upwards for clients on which they have higher economic dependence. This provides further support for hypothesis 1 . Supporting hypothesis 2 , the regressions based on abnormal working capital accruals show that auditors do not allow more earnings management discretion to more influential clients that manage earnings downwards. In fact, auditors constrain downward earnings management for clients with a stronger economic bond.

\subsubsection{Additional tests}

Further tests shows that results are robust to omitting publicly traded companies or companies with consolidated financial statements, excluding observations belonging to audit partners with small client portfolios (consisting of less than four clients), including industry dummies based on two-digit NACE-codes, measuring going concern risk (PBANK) using a continuous variable, and limiting the estimation of discretionary accruals to industries with at least 30 observations.

Furthermore, auditor-client economic bonding is estimated using Herfindahl weights, which place more weight on clients with a high economic-bonding than the previously used continuous measure. Using the Herfindahl weights yields results similar to, but not stronger than, those obtained using the continuous measure of auditor-client economic bonding. 


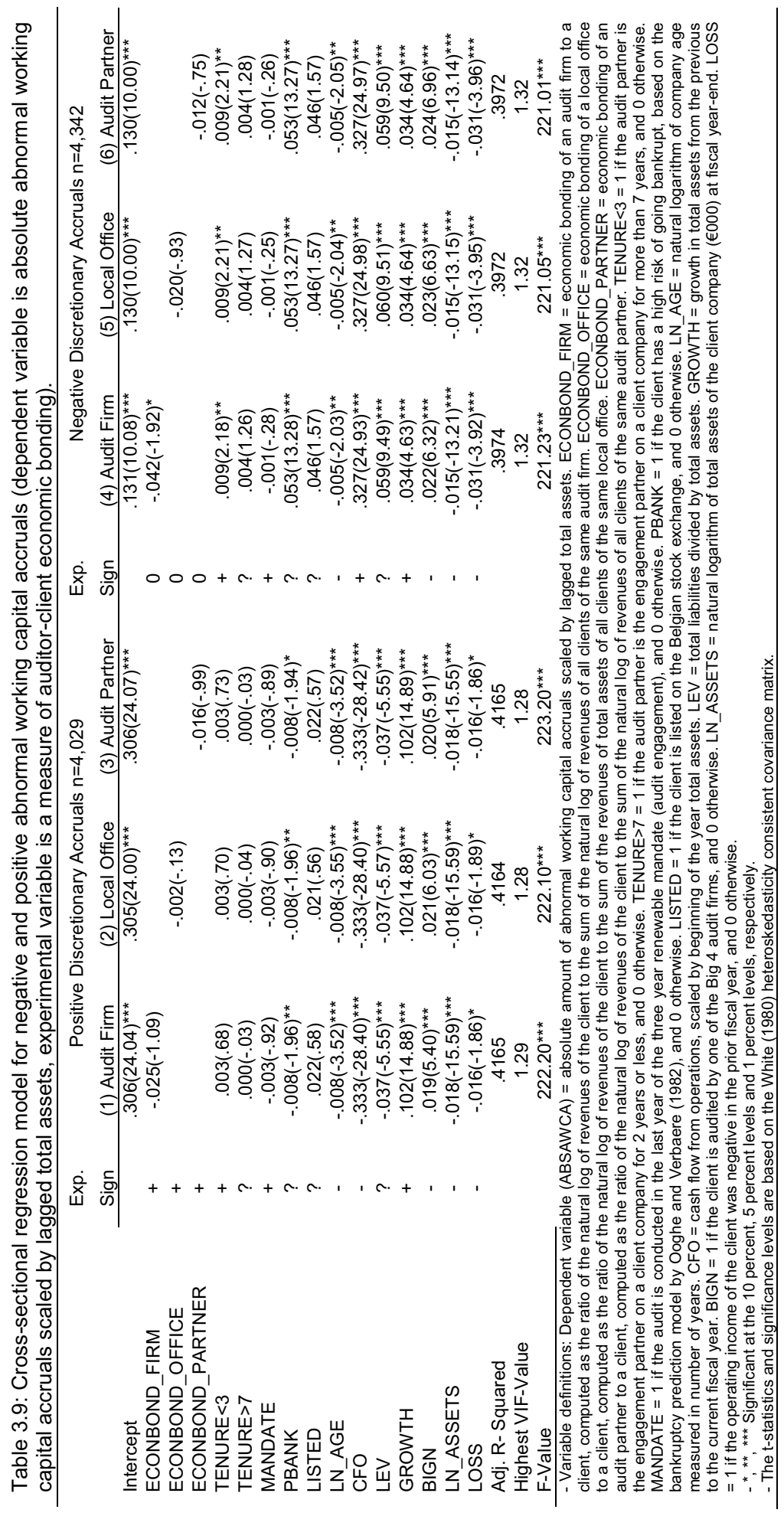




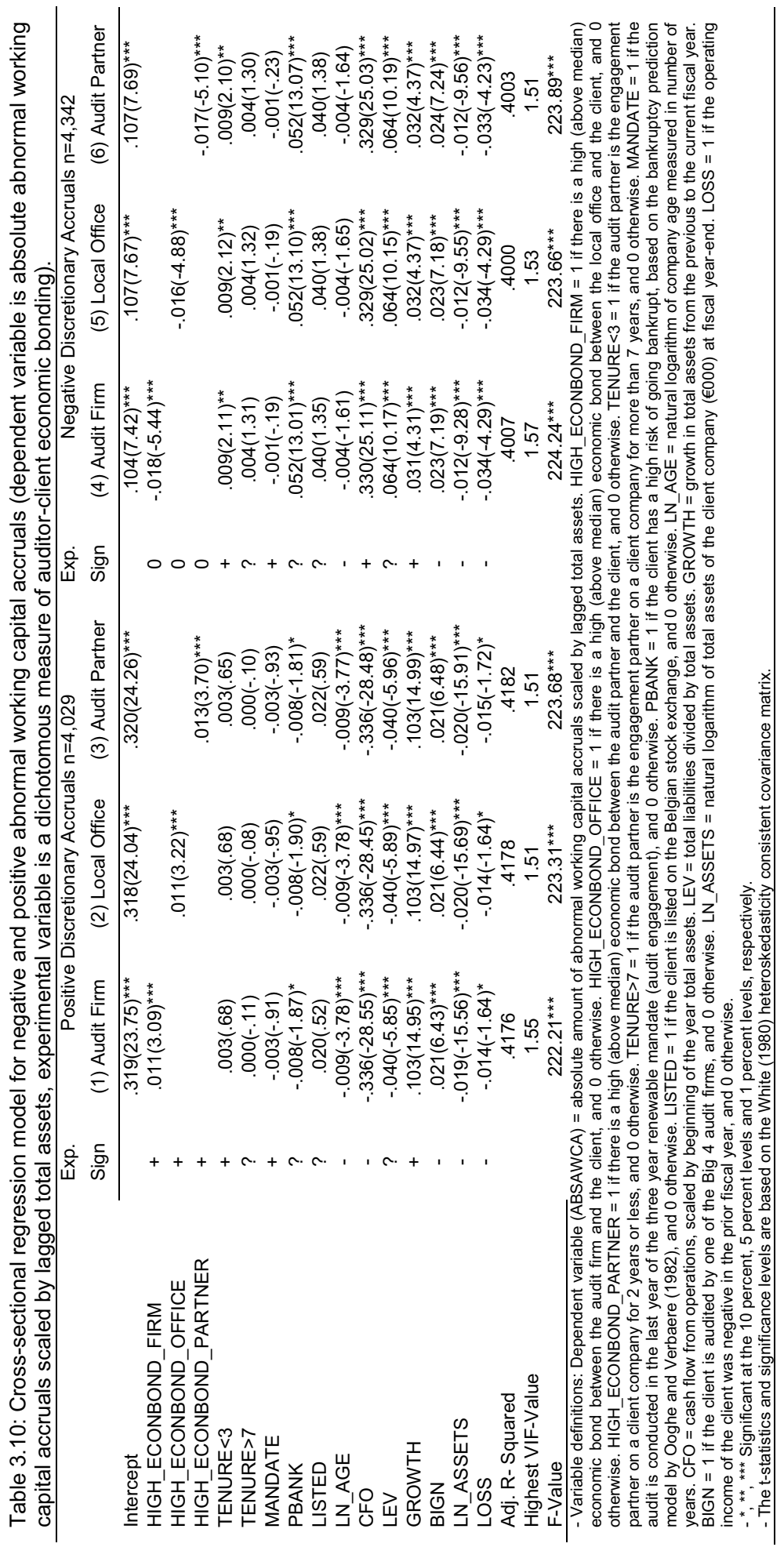


The results are generally consistent across all levels of decision making within the audit firm. To examine whether auditor-client economic bonding is more likely to impair audit quality at lower levels of decision making within the audit firm, the seemingly unrelated regression (SUR) model is used to test whether the models, estimated at the three levels of decision making within an audit firm, differ significantly from each other. Results do not support the argument that auditor-client economic bonding is more likely to manifest itself at lower levels of decision making.

\subsection{Conclusion and limitations}

\subsubsection{Conclusion}

Auditors are required to provide an independent opinion on the reliability of the financial statements of their clients. However, clients pay the auditor for performing the audit, making it impossible for auditors to be completely independent from their clients. Regulators have expressed concerns as to whether auditors can remain sufficiently independent from their more influential clients.

Using data on statutory audits conducted in Belgium, this paper examines whether audit firms acquiesce to pressure by clients with a stronger economic bond to allow them more discretion to manage earnings. The Belgian setting creates the opportunity to incorporate both public and private companies in the construction of client portfolios, resulting in more accurate measures of economic client dependence. Furthermore, it allows examining the effect of auditor-client economic bonding on audit quality at three levels of decision making: the audit firm level, the local office level, and the audit partner level.

Consistent with the hypotheses, this study finds evidence that audit firms allow more earnings management discretion to clients on which they have stronger economic dependence. This implies that strong auditor-client economic bonding impairs audit quality. This result is however limited to clients that manage their earnings upwards. Auditors do not allow clients more discretion to manage earnings downwards, possibly because tax authorities are more likely to scrutinize the financial statements of companies which engage in income, and hence tax, decreasing earnings management. Auditors only allow clients more discretion to manage earnings when clients manage earnings upwards. Hence, consistent with prior studies (e.g. Vander Bauwhede et al. 2003; Van Tendeloo and Vanstraelen 2008), it seems that public oversight mitigates the detriment of economic bonding. This study therefore underlines the importance of public oversight.

\subsubsection{Limitations and future research}

One limitation of the current study is that it measures auditor-client economic bonding based on client revenues instead of audit fees, because audit fee data was not publicly available in Belgium at the time of the study. The natural logarithm of client revenues is however found to be highly correlated 
with audit fees (e.g. Francis 1984, Craswell et al. 1995, Reynolds and Francis 2001). In addition, the Belgian Institute of Auditors requires a direct relationship between the level of the audit fees and client characteristics. Every auditor has to report an overview of its clients, the audit fees and the amount of hours to the Belgian Institute of Auditors, who verify the appropriateness of the audit fees. The use of client revenues instead of audit fees does therefore not seem to be a major concern. It would still be valuable to replicate this study at a later moment in time, if a setting becomes available where regulators require both public and private companies to disclose audit fees.

Even though auditors are expected to be more likely to acquiesce to client pressure to allow earnings management in the last year of their three year renewable contract, no effect of MANDATE on the degree of earnings management by clients is found. Future research could use data on the subsequent fiscal year to examine whether an auditor switch occurred. Such a switch is likely to indicate that negotiations between auditor and client were more difficult than for cases where the audit mandate was renewed. It would be interesting to test whether more earnings management discretion was given to clients that subsequently switched to another audit firm, because the auditor might have been under pressure to allow client earnings management in order to increase the likelihood of mandate renewal. 


\section{Notes}

${ }^{1}$ Requiring the financial statements to be prepared in all material aspects in accordance with applicable financial reporting standards.

${ }^{2}$ Belgium is characterized by a high alignment between financial reporting and tax accounting. As a result of this, tax authorities are one of the main users of the financial statements. The Belgian tax authorities provide a credible threat which is comparable to the threat provided by financial analysts, investors or stock market regulators (Vander Bauwhede et al. 2003; Van Tendeloo and Vanstraelen 2008).

${ }^{3}$ A client's influence is measured relative to the influence of the other clients within an auditor's client portfolio. Given that most clients do not have a stock exchange listing, omitting these clients from the sample makes that the relative influence of the included clients will be significantly overstated.

${ }^{4}$ A higher probability of material misstatement detection can also be argued to result in higher litigation costs. These costs are however small in low litigious environments. The effect of high tax alignment on litigation costs in a low litigious environment, such as Belgium, will therefore be small.

${ }^{5}$ This relies on the assumption that all clients audited by an audit partner pertain to the same local practice office.

${ }^{6}$ As explained in section 3.3.2, this study uses the amount of discretionary accruals to proxy for audit quality. These outliers are removed because the estimation of discretionary accruals is likely to be unreliable for companies that experienced extreme growth (or declines) in sales (Carey and Simnett 2006). Companies in the top and bottom 1\% of the distribution of changes in revenues are classified as outliers.

${ }^{7}$ Kothari et al. (2005) demonstrate that controlling for firm performance using current year return on assets $(R O A)$ instead of lagged ROA results in a better performing accrual measure.

${ }^{8}$ Consistent with Leuz et al. (2003), cash flows from operations are computed as operating income minus total accruals.

${ }^{9}$ Audit fees are also commonly proxied for by the total assets of a client (Hay et al. 2006). The results are robust to calculating economic client dependence based on client total assets.

${ }^{10}$ Hunt and Lulseged (2007) measure economic client dependence using the log of sales, as well as using client audit fees. Coulton and Ruddock (2007), and Coulton et al. (2007) also use audit fees to measure economic client dependence.

${ }^{11}$ In Belgium audits are assigned based on three year renewable contracts. One of the aims of this requirement is preventing the occurrence of low-balling and its possible detrimental effect on audit quality.

12 The audit partner appointment date was unavailable for 161 observations. For these observations audit partner tenure is computed based on audit partner data available from 1998 until 2006. Hence, audit partner tenure could be computed for all observations in the initial sample.

${ }^{13}$ The results on TENURE<3 AND TENURE $>7$ are robust to increasing or decreasing the cutoffs by one year. Using a continuous measure of tenure yields no significant results.

${ }^{14}$ The mandate usually starts at the annual meeting of shareholders which assigned the auditor, and ends at the annual meeting of shareholders following the third statutory audit (IBR, 2004). 
${ }^{15}$ The appointment data of the audit firm was unavailable for 59 observations. For these cases, MANDATE is computed based on observed audit firm switches.

${ }^{16}$ The variables MANDATE and TENURE $<3$ measure two separate constructs. TENURE $<3$ refers to length of the audit engagement, MANDATE indicates whether the audit is conducted in the last year of the renewable mandate. The correlation between the two variables is negative (.084 ) and significant. Excluding either of the two variables from the model does not have a notable effect on the coefficient or significance of the other variable.

17 Big $N$ refers to the four largest audit firms: Deloitte, Ernst \& Young, KPMG, and PricewaterhouseCoopers.

${ }^{18}$ Variables are winsorized at the top and bottom $1 \%$ to remove the influence of outliers.

19 This also follows from the low variance inflation factors (VIFs) when estimating the OLS regressions. The highest VIF across all regressions is 2.71 .

${ }^{20}$ Auditors might compromise audit quality in the second year of the mandate if the decision to renew the mandate is taken one year before the end of the mandate. Further analysis shows that auditors do not allow clients more room to manage earnings in the second year of the mandate either. Hence, there is no evidence that auditors compromise audit quality in second year of the engagement in order to increase the probability of being selected as the auditor in the subsequent 3 years.

${ }^{21}$ No dummy variable for ECONBOND_Q1 is included in the regression model, because including dummy variables for all categories would cause perfect multicollinearity. 



\title{
Chapter 4 \\ Competition and Quality in the Market for Audit Services
}

\begin{abstract}
This study investigates the extent to and manner in which competition in the market for audit services affects audit quality supplied by auditors. Data on the audit market, client portfolios and client earnings management in Belgium is used to examine the relationship between competition and quality in the auditing industry. Spatial analysis and dynamic market share analysis are used to analyze the level of competition in the audit market. Geographical coordinates of local audit offices and audit clients are used to compute the degree of local competition faced by auditors.

Three separate measures of competition are used to examine the effect of competition on audit quality. First of all, a locally defined Herfindahl index is used to measure local market concentration. Second, changes in market shares are used to test the relationship between competition and audit quality at three different levels: the audit firm level, the local audit office level and the audit engagement partner level. Finally, a competitor density measure is introduced to proxy for local competition.

Results suggest that increased competition in the market for audit services is associated with higher audit quality. Furthermore, the results indicate that high concentration ratios do not necessarily result in lower competition and reduced audit quality.
\end{abstract}

Key Words: Competition, Audit Quality, Audit Portfolios.

\subsection{Introduction}

The impact of competition in the market for audit services on auditor behavior has been examined since the study of Zeff and Fossum (1967). Research on the effect of competition on audit quality is driven by concerns that the audit market is not competitive (e.g. Dopuch and Simunic 1980; Hermanson et al. 1987). These concerns are related to high concentration levels in the markets for audit services (Pearson and Trompeter 1994; Buijink et al. 1998). In highly concentrated industries there is an increased potential for collusive behavior by the largest suppliers, which would result in reduced competition (Yardley et al. 1992).

For most of the $20^{\text {th }}$ century, the audit market was dominated by eight large accounting firms, commonly referred to as the Big 8. The market for audit services became more concentrated in 1989, as the Big 8 turned into 
the Big 6 as a result of two mergers. In this year, Ernst \& Whinney merged with Arthur Young, and Deloitte, Haskins \& Sells merged with Touche Ross. The market concentration further increased when the Big 6 became the Big 5 due to the merger of Price Waterhouse with Coopers \& Lybrand in 1998. The demise of Arthur Andersen in 2002 reduced the number of large international audit firms to four. This further increased concerns about the effect of high concentration in the market for audit services on audit quality (Government Accountability Office 2003). High concentration levels are, however, not necessarily related to reduced competition, since a market can be competitive despite high (static) concentration levels (Buijink et al. 1998). ${ }^{1}$ It is therefore important to examine the effect of competition on audit quality, as opposed to the effect of concentration levels on audit quality. Research on the relationship between competition and audit quality is required to support regulators in maintaining and enhancing audit quality.

There is theoretical justification to link competition and quality. The economics of industrial organization can be used as a conceptual framework to specify the relationship between competition and quality. The structureconduct-performance paradigm (S-C-P) implies that conditions of supply and demand determine market structure, which in turn determines firm behavior, which subsequently determines firm performance, of which quality is an example. It is unclear what the effect of competition on audit quality is. Standard economic theory argues that competition will have a positive effect on quality (e.g. Spence 1975; Leland 1977; Mussa and Rosen 1978). However, it is not clear if this also holds for the market of audit services for a number of reasons. First of all, audits are labor intensive services of which the quality level is difficult to observe. Competition in markets where the quality level is hard to observe may have a negative impact on the incentives of suppliers to invest in providing high quality products (Leland 1979; Kranton 2003). Second, reduced audit fees as a result of competition may make auditors more dependent on clients, since auditors will rely more on future quasi rents to offset initial losses (DeAngelo 1981a). Reduced auditor independence results in lower audit quality (DeAngelo 1981b). Finally, the market for audit services is a highly regulated market. Educational, licensing and certification requirements are imposed by regulators to ensure audit quality. Besides ensuring a minimum quality level, these requirements act as barriers to entry that may limit competition in the audit market (Dopuch and Simunic 1980). Furthermore, entry into the top-tier section of the audit market has proven to be very difficult for mid-sized audit firms, due to the required capacity and recognition thereof needed to audit publicly traded companies (European Commission 2010). Hence, while economic theory predicts a positive association between competition and quality, it is not clear what the effect of competition on audit quality is due to the specific characteristics of the audit market.

Several studies have tested whether the market for audit services is competitive (e.g. Simunic 1980; Buijink et al. 1998). However, the number of studies that have attempted to test the effect of the level of competition in the audit market on audit quality is low (e.g. Copley and Doucet 1993; Johnstone and Bedard 2004). This study contributes to the audit literature in two ways. 
First, unlike prior studies, this study incorporates both listed and non-listed audit clients in the construction of auditors' client portfolios. It is important to analyze complete portfolios since decisions made by an auditor with respect to individual clients will be influenced by the auditor's complete client portfolio, consisting of both publically listed and privately traded companies (Simunic and Stein 1990). The analysis of the effect of competition on audit quality based on complete audit portfolios will therefore result in more insightful results than an analysis based on publically listed clients only. Second, this study introduces a local competitor density measure. Compared to previously used measures, the local competitor density measure incorporates the geographical locations of auditors and audit clients more precisely, which enables it to better measure local competition.

To examine the relationship between competition in the market for audit services and the quality of audit services that auditors supply, data is used on audits conducted in Belgium between 1998 and 2006. Audit quality is proxied by discretionary accruals. The extent of competition that an auditor faces is measured using three separate measures. First of all, based on the geographical locations of local audit offices and audit clients, a Herfindahl index is computed for each local audit market. Although concentration ratios, such as the Herfindahl index, are commonly used in audit research, it can be questioned whether concentration ratios capture competition. The Herfindahl index is used to enhance the comparability of this study with prior literature. Second, a measure of market share mobility is used to measure the degree of competition at three levels: (1) the audit firm level, (2) the local practice office level, and (3) the audit engagement partner level. This measure is based on absolute changes in market share. Third, based on geographical locations of auditors and both actual and potential clients, a local competitor density measure is computed. Competitor density is a function of the number of competing auditors and the number of potential audit clients per local audit market. The advantage of this measure is that it reflects that there is a different set of possible auditors for each client as a result of geographic dispersion of clients and auditors within local audit markets.

The results based on the Herfindal index suggest that audit quality is higher in more concentrated audit markets. Results based on the mobility measures show that absolute changes in audit firm market shares are positively related to audit quality. There is, however, no significant association between audit quality and changes in market shares of local audit offices and audit partners. The lack of a significant association between market share mobility, measured at the local office level and audit partner level, and audit quality is most likely due to the relatively small changes in market shares at these levels of analysis. The final measure of competition, competitor density, is negatively associated with the absolute amount of discretionary accruals, suggesting a positive association between competition and audit quality. Hence, overall, the results suggest that competition in the market for audit services is positively associated with audit quality. Furthermore, the results show that market concentration and competition are two separate concepts. This is in line with prior studies that showed that audit markets can be competitive despite high concentration levels (e.g. Buijink et al. 1998). 
The next section discusses prior literature on the link between competition and quality, followed by hypothesis development. Section 4.3 outlines the methodology and data selection. Results are provided in section 4.5, followed by conclusions in section 4.5 .

\subsection{Prior literature and hypothesis development}

Audit quality is defined as the joint probability that a material misstatement is detected, and subsequently reported by the auditor (DeAngelo 1981b). From this follows that audit quality is a function of both auditor competence and auditor independence. Both of these factors can be affected by the level of competition in the audit market. Competition may eliminate the price premium needed to induce companies to provide high quality products (Kranton 2003). Hence, auditors might respond by allocating fewer resources to clients that pay relatively low audit fees. This would harm auditor competence and increase the probability that material misstatements are not detected by the auditor. Furthermore, competition may lead to situations where auditors accept lower than normal audit fees in order to obtain or retain a client, expecting to offset low revenues or early losses with quasi rents to be charged for future audits, which may result in impaired independence (DeAngelo 1981a). Thus, competition may negatively affect audit quality by impairing either auditor competence or auditor independence.

Prior studies have analyzed the effect of market concentration on audit fees (e.g. Pearson and Trompeter 1994; Johnson et al. 1995; lyer and lyer 1996; Willekens and Achmadi 2003; Bandyophadhyay and Kao 2004), the effect of competition on audit fees (e.g. Maher et al. 1992), and the effect of audit market concentration on audit quality (Kallapur et al. 2008). Research on the association between competition in the market for audit services and audit quality is however sparse (e.g. Copley and Doucet 1993; Johnstone et al. 2004). ${ }^{2}$

This section discusses prior literature on competition and audit quality. Standard economic theory on the relationship between competition and quality in product markets is discussed in section 4.2.1. Section 4.2.2 looks at the effect of competition on quality in service markets. Section 4.2.3 focuses more specifically on the effect of competition in the market for audit services on audit quality, and furthermore provides hypothesis development.

\subsubsection{Competition and quality in product markets}

Numerous economic studies have examined how competition influences quality for product markets (see Spence 1975; Leland 1977; Mussa and Rosen 1978, Banker et al. 1998; Kranton 2003). This section gives an overview of the main findings of these studies.

Spence (1975) argues that the quality level provided in a non-competitive market is likely to deviate from the optimal level of quality because of discrepancies between average and marginal valuations of quality by consumers. Hence, this study shows a negative association between competition 
and quality. This is confirmed by Leland (1977) who analytically shows that monopolists under-provide quality given an output level. Mussa and Rosen (1978) show analytically that it is beneficial for a monopolist to increase the total quality range by reducing the quality level at the lower end. Average quality would, therefore, rise with increased competition. Additionally, the prices set by a monopolist will be higher than the competitive prices for any quality level. Overall, these studies suggest that increased competition will result in higher quality.

While the above mentioned studies suggest a positive association between competition and quality, Banker et al. (1998) analytically show for an oligopolistic market that the effect of competition on quality depends on the cost functions of the dominant and the smaller companies. Increases in the number of competitors result in improved quality, unless the dominant firm has a relative cost advantage in providing quality. Competition results in reduced quality when the dominant firm is able to provide quality at a lower cost than the smaller competitors.

Kranton (2003) also questions the positive effect of competition on quality. She argues that competition for market shares can eliminate the price premium needed to induce companies to produce high quality products, and states that companies trade-off the one-time benefit of providing low quality for the high quality price (saving the costs of delivering high quality compared to the costs of delivering low quality) against the discounted value of future profits from delivering high quality to repeat buyers. Increases in competition may, therefore, reduce the quality level.

The studies in this section all relate to produce markets. The next session discusses the effect of competition on quality for service markets.

\subsubsection{Competition and quality in service markets in general}

The previous section discussed the effect of competition on quality for product markets. Service markets, however, differ in various ways from product markets. As opposed to product markets, service markets in general involve a lack of inventories and portability, a high degree of customer contact, possible joint production, customer-specific inputs, and intangibility (Karmarkar and Pitbladdo 1995). Economic theories on product markets may not apply to markets for services due to the fact buyer knowledge may be different in service markets than in product markets (Yardley et al. 1992).

For a market where the quality level is not observable, Leland (1979) shows analytically that increases in the number of competing firms result in diminished incentives for companies to invest in quality improvements since each firm undertaking quality improvements bears the full cost of those improvements, while the benefit from the improvements is shared by all competing firms. In case of a lot of competing firms, the average increase in quality from a quality improvement by a single firm will approach zero. Hence, the optimal level of quality improvement for each firm will be zero. From this can be concluded that competition may have a negative effect on quality when the quality level is not observable. 
Several studies have examined the effect of competition on quality for service markets. For example, Domberger and Sherr (1989) show that liberalization of the market for legal services in the United Kingdom and Wales resulted in reduced fees and increases in satisfaction ratings. Hence, they show that increased competition resulted in improved quality. Bradford and Martin (2000) examine the effect of partnerships on quality in the medical profession. They conclude that partners only compete on quality when demand is restricted. Mazzeo (2003) examines the relationship between competition and quality in the U.S. airline market. He shows that high market concentration is associated with longer flight delays and longer scheduled flights, and concludes that increased competition has a positive effect on service quality.

In conclusion, while Leland (1979) found analytically that competition may reduce quality when the quality level is not directly observable, Domberger and Sherr (1989), Bradford and Martin (2000), and Mazzeo (2003) reported positive associations between competition and quality for service markets. The next section discusses the effect of competition on quality for the market for audit services.

\subsubsection{Competition and quality in the audit market}

The previous section discussed the effect of competition on quality for service markets. The audit market, however, is a service market with specific regulations (Yardley et al. 1992). The arguments provided in the previous section may therefore not be applicable to the market for audit services. The market for audit services is characterized by standards and regulations aimed at assuring a minimum quality level, such as educational requirements, licensing and mandatory peer-reviews. These requirements create barriers to entry at the firm level and the partner level. Dopuch and Simunic (1980) argue that the significance of barriers to entry at the firm level, as opposed to barriers to entry at the individual level, provide an explanation for the dominance of large accounting firms in the market for audit services, a dominance which is not observed in other service markets. Despite the dominance of large audit firms, Dopuch and Simunic conclude that the market for audit services is competitive based on a comparison of audit fees between Big $\mathrm{N}$ and non-Big $\mathrm{N}$ audit firms. This section will continue by first giving an overview of a number of analytical studies. The discussion will then continue by looking at empirical studies that examined the effect of competition on audit quality. This section concludes with the hypothesis development.

Ronnen (1991) shows analytically that imposing minimum quality standards will result in intensified competition since it decreases the range of quality levels which sellers can provide. Minimum quality standards force low quality sellers to increase their quality as to meet the standards. ${ }^{3}$ Hence, imposing minimum quality standards will increase both quality and competition, suggesting that there is a positive association between competition and audit quality. 
An economic analysis by Hermanson et al. (1987) shows that increases in competition enforced by regulators results in lower audit fees. They further argue that price reductions may result in impaired audit quality if these lower prices do not allow audit firms to earn a normal profit. Lower audit fees may force auditors to reduce their emphasis on providing high quality audits. Instead, they may try to generate revenues through other, more profitable, non-audit services. From this follows that competition and audit quality are likely to be negatively associated. This is opposite to the positive association that followed from the analytical model presented by Ronnen (1991).

Chaney et al. (2003) also use an analytical approach to examine the relationship between competition and audit quality. They argue that when deciding whether to report a misstatement or not, auditors trade off the cost of reporting misstatements in a client's financial statements and the litigation and reputation costs in case an audit failure is detected. The cost of reporting a material misstatement equals the loss of future revenues in case the audit contract is terminated by the client. The authors state that the degree of competition is not expected to influence the litigation and reputation cost of not reporting truthfully. However, the effect of competition on the cost of reporting a material misstatement is unclear. Competition will lower the cost of reporting a material misstatement because audit fees and revenues will fall. However, competition may also increase the cost of reporting a material misstatement, because the probability that a client switches to another audit firm increases. The net effect of reduced audit fees and increased likelihood of losing a client on the cost of reporting a material misstatement is not directly clear. Hence, based on this analytical model it is not possible to conclude what the effect of increased competition on audit quality is.

In addition to these analytical studies, there are a number of studies which empirically test the effect of competition on audit quality. Copley and Doucet (1993) use archival data to examine the impact of competition on audit quality for U.S. governmental audits. Using audit quality assessments by Regional Inspectors General they define audit quality as a dichotomous variable, indicating either acceptable or unacceptable quality. Measuring competition as the number of soliciting bids for the audit engagement, the authors conclude that increased competition leads to higher quality audits. In addition they conclude that increased competition lowers audit fees. This study provides evidence of a positive association between competition and audit quality.

Based on the evaluations of prospective clients by a single audit firm, Johnstone et al. (2004) test for the differences in engagement planning and audit pricing between situations with competitive bidding and situations with non-competitive bidding (i.e. whether or not there were other audit firms bidding on the prospective client). They find that when the audit firm is in a competitive bidding environment, planned audit hours are higher, while audit fees are lower. This suggests that competition may lead to higher audit quality.

Kallapur et al. (2008) test the effect of local competition on audit quality. They use the Herfindahl index of market concentration measured at the metropolitan statistical area level (i.e. city level) as a proxy for competition, and 
accrual based measures as proxies for audit quality. They find that audit quality is higher in more concentrated markets.

Similary, Francis et al. (2010) report, based on a sample of audits conducted in 40 different countries, that the quality of Big $\mathrm{N}$ audits is positively associated with Big $\mathrm{N}$ market share concentration. However, concentration within the Big N results in reduced audit quality.

Because of the mixed theoretical arguments and empirical findings, the following non-directional hypothesis is posed:

Hypothesis: Competition in the market for audit services influences audit quality.

The next section discusses the sample selection and methodology used to test this hypothesis.

\subsection{Methodology}

This section discusses the methodology used to test the hypothesis stated in the previous section. Section 4.3.1 discusses the sample selection. This is followed by a discussion of the proxy of audit quality in section 4.3.2. The experimental variables are presented in section 4.3.3. The selection of control variables is discussed in section 4.3.4. The regression models that are used to test the effect of competition on audit quality are provided in section 4.3.5.

\subsubsection{Sample selection}

To test the hypothesis, the data need to meet a number of requirements. First of all, client portfolios for every audit firm, local audit office and engagement partner need to be constructed to measure the effect of competition between audit firms. This requires that the name of the audit firm, the local office location, and the name of the engagement partner are available for every audited company. Second, to measure competition at the local office level and the audit partner level, data on audit office location and client location are required. Finally, financial data for the audited companies is required.

For the purpose of this study, the Belgian audit market meets the above mentioned requirements. Data are obtained from three different data sources: The Bel-First database, membership lists of 'het Instituut van de Bedrijfsrevisoren' (IBR, the Belgian Institute of Auditors), and Google Earth.

The Bel-First database contains the financial data of companies which are required to have their accounts audited and which have to submit their annual accounts to the National Bank of Belgium. These financial statements also include the name of the audit firm that has audited the client. Furthermore, the name of the individual auditor signing the audit report can be derived from these reports. By analyzing audited financial statements it is 
therefore possible to construct complete client portfolios of all Belgian audit firms, local practice offices and audit partners.

The annual membership lists of the IBR list all active individual auditors and audit firms for each year. The membership lists of the IBR are used to determine at which local office an audit partner is employed. The membership list of 2006 was the most recent membership list available at the time of the study. Financial data and information about the audit firm and the engagement partner were available from 1998 onwards. The dataset is therefore restricted to audits conducted between 1998 and 2006. Financial data from the Bel-First database are collected from unconsolidated financial statements in order to accurately measure client shifts between audit firms.

The third data source, Google Earth, is used to determine the geographical coordinates of auditor and client locations. These coordinates are used to measure the distance between each actual and possible auditor-client pair. These distances are used to construct proxies for the degree of competition in local audit markets.

In the Bel-First database, 167,377 company-year observations $(28,735$ unique companies) are available between 1998 and 2006. For ease of reference, this sample is labelled sample A. Observations are removed for reasons discussed below (see also Table 4.1 below).

First of all, observations are removed for which the audit firm name, audit partner name, local audit office location or client location are missing $(n=13,098)$. In order to enable the computation of changes in audit partner portfolios, audit clients with more than one audit partner are removed $(n=12,368)$. Observations for which total assets are unknown are removed as well $(n=906)$, because the competition measures are computed based on client assets. This results in a sample of 141,005 observations $(26,844$ unique companies) which is used to compute the experimental variables. This sample is referred to as sample B.

In order to construct the sample based on which the effect of competition on audit quality is examined, another 38,539 observations with missing financial information are removed. Utilities (four digit NACE industry codes between 4,000 and 4,100) and financial institutions (four digit NACE-codes between 6,500 and 6,720$)$ are removed from the sample $(n=9,470)$, because of their specific audit requirements and circumstances. Furthermore, 1,856 observations with extreme sales volatility, as well as 341 observations in industries with less than 10 observations are excluded from the sample, because the regression model used to construct the audit quality measure cannot be reliably estimated for these observations. ${ }^{4}$ This results in a sample of 90,529 observations $(19,025$ unique companies) which is used to examine the effect of competition in the market for audit services on audit quality. This sample is referred to as sample $\mathrm{C}$. 
Table 4.1: Sample selection

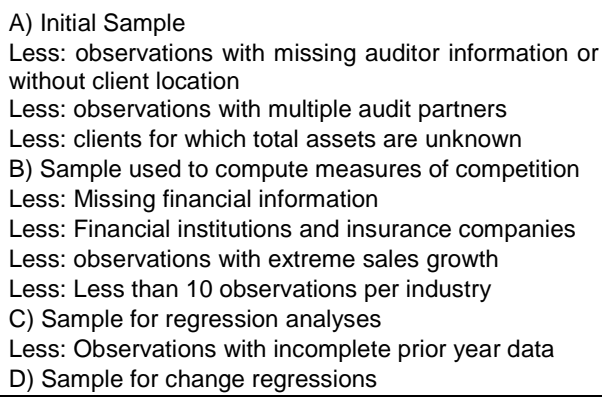

$-13,098$

$-12,368$

$-906$

$-38,539$

$-9,470$

$-1,856$

$-341$

$-31,176$
167,377

141,005

90,529

59,353

This study also examines the effect of market share mobility on relative changes in audit quality between years. This requires the availability of current and prior year financial and auditor information. A lack of prior year data results in the removal of 31,176 observations. The effect of changes in competition on changes in audit quality is tested based on a sample of 59,353 observations (15,359 unique companies). This sample is referred to as sample D.

\subsubsection{Dependent variable}

Prior studies have used several proxies for audit quality, such as the number of court decisions in which an auditor was found guilty of performing below the required level (e.g. Palmrose 1988), the frequency of earnings restatements (Raghunandan et al. 2003; Kinney et al. 2004), and the likelihood of issuing a qualified audit report (e.g. Hopwood et al. 1994; Vanstraelen 2000). The most commonly used proxy for audit quality relates to the level earnings management by clients. High quality audits are argued to constrain management's choice of accounting procedures which are used to manage earnings (e.g. Becker et al. 1998, Francis et al. 1999, Reynolds and Francis 2001, Myers et al. 2003, Krishnan 2003, Carey and Simnett 2006). Client earnings management is commonly proxied by discretionary accruals.

This study uses the modified Jones-model (1991) to estimate the quality of the reported earnings using discretionary accruals. Consistent with prior studies (e.g. Ashbaugh et al. 2003; Kothari et al. 2005), this study controls for performance using current year return on assets (ROA). ${ }^{5}$ Lagged total accruals are included to control for the reversing nature of accruals (e.g. DeFond and Park 2001). An intercept is included, because this allows controlling for heteroscedasticity, and mitigates problems due to an omitted size variable (Kothari et al. (2005). The following model is estimated for each industry and year:

$$
\begin{aligned}
& \operatorname{TACC}_{i j t}=\beta_{0}+\beta_{1}\left(\frac{1}{A_{i j t-1}}\right)+\beta_{2}\left(\Delta S A L E S_{i j t}-\Delta R E C_{i j t}\right)+\beta_{3} P P E_{i j t}+ \\
& \beta_{4} R O A_{i j t}+\beta_{5} T A C C_{i j t-1}+\epsilon_{i j t}
\end{aligned}
$$




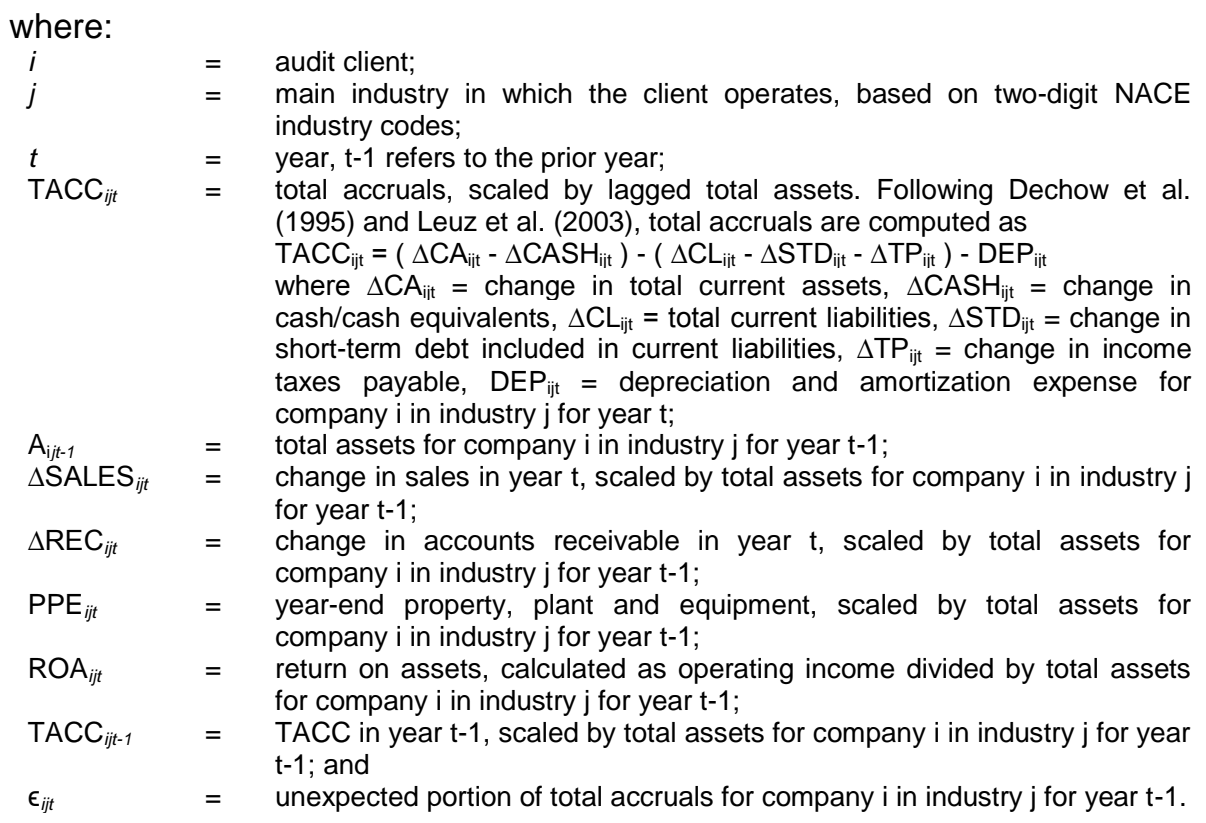

The residual of the model $\epsilon_{\mathrm{ijt}}$ is used as the measure of discretionary accruals. Higher discretionary accruals are associated with more client earnings management, and therefore reflect lower audit quality.

\subsubsection{Experimental Variables}

This study uses three different measures of competition. As explained in section 3.1, the experimental variables are computed based on sample B, which includes 141,005 observations.

Table 4.2 gives an overview of the three experimental variables. The first measure is the Herfindahl index. This measure of market concentration is computed at the local office level. The effect of market concentration on audit quality is tested using sample $C$, which is the largest possible sample that allows testing the effect of market concentration on audit quality. The second experimental variable is the market share mobility measure. The effect of market share mobility on audit quality is examined at the audit firm level, the local office level, and the audit partner level. The regressions used for market share mobility are based on sample $D$ because prior year data is required to compute market share mobility. The final measure of competition, competitor density, is computed at the audit partner level. This is required to control for the capacity levels of local audit offices. The regressions based on competitor density are estimated using sample $\mathrm{C}$.

The three different measures of competition and their respective levels of analysis are discussed in detail in sections 3.3.1 to 3.3.3. 
Table 4.2: Overview of the experimental variables and the levels of analysis at which each variable is measured.

\begin{tabular}{|c|c|c|c|c|}
\hline \multirow[t]{2}{*}{$\underline{\text { Variables }}$} & & \multicolumn{3}{|c|}{ Level of analysis } \\
\hline & & Firm level & Local office level & Audit partner level \\
\hline $\begin{array}{l}1 . \\
2 .\end{array}$ & $\begin{array}{l}\text { Hertındahl Index } \\
\text { Market share mobility }\end{array}$ & $x$ & $\begin{array}{l}x \\
x\end{array}$ & $x$ \\
\hline 3. & Competitor density & & & $\hat{x}$ \\
\hline
\end{tabular}

\subsubsection{Experimental variable: Herfindahl index}

The first measure used to proxy for competition is the Herfindahl index, which is a concentration measure that audit researchers have adopted from the area of industrial organization. Most of the criticism on the auditing industry relies on the concentration doctrine, which provides a motivation for concentration-performance studies in the audit literature (Dopuch and Simunic 1980). One advantage of the Herfindahl index over other concentration ratios, such as the $\mathrm{C} 4$ and $\mathrm{C} 8$ ratios, is that it takes the market shares of all market participants into account, as opposed to the market shares of only the largest companies.

The degree of seller concentration in a market is commonly interpreted as a measure of the degree of competition in a market (e.g. Carlton and Perloff 1994). However, despite the fact that concentration measures are commonly used in audit research to proxy for competition (e.g. Simunic 1980; Pearson and Trompeter 1994) it can be questioned whether concentration measures actually capture the level of competition in a market. A dynamic analysis of audit market structure by Buijink et al. (1998) shows that audit markets are competitive notwithstanding high (static) concentration levels. Concentration ratios, for example, may not capture price cutting and dynamics of relative market share, which would be a sign of competitive behavior (Yardley et al. 1992; Pearson and Trompeter 1994).

Recognizing the criticism on the use of concentration ratios as proxies for competition, this study uses the Herfindahl index for two reasons. First of all, it is used to enhance the comparability of this study with prior studies. Second, the simultaneous use of this measure and two other proxies for competition can provide further insight into the mixed evidence found by prior studies on the relationship between competition and audit quality.

The Herfindahl index (HERFINDAHL ${ }_{k}$ ) is computed as follows:

$$
\text { HERFINDAHL } L_{k}=\left(\sum_{i=1}^{N_{k}}\left[T A_{i k} / T A_{k}\right]^{2}\right)
$$

where:

\begin{tabular}{|c|c|c|}
\hline $\mathrm{HERFINDAHL}_{k}$ & $=$ & Herfindahl index for local audit market $k$; \\
\hline$k$ & $=$ & local audit market; \\
\hline $\begin{array}{l}i \\
N_{k}\end{array}$ & $=$ & local audit office that audits clients in the local market $k$; \\
\hline $\mathrm{N}_{k}$ & $=$ & $\begin{array}{l}\text { number of local audit offices that compete for audit clients within } \\
\text { local market } k \text {; }\end{array}$ \\
\hline $\mathrm{TA}_{i k}$ & $=$ & $\begin{array}{l}\text { the sum of the natural logarithms of total assets of all clients } \\
\text { within local audit market } k \text { that are audited by audit office } i \text {; and }\end{array}$ \\
\hline $\mathrm{TA}_{k}$ & $=$ & $\begin{array}{l}\text { the sum of the natural logarithms of total assets of all clients } \\
\text { within local audit market } k \text {. }\end{array}$ \\
\hline
\end{tabular}


The Herfindahl index is measured at the local office level, consistent with the argument by Wallman (1996) and Francis et al. (1999) that competition takes place at the local office level. Using a Herfindahl index measured at the firm level is not feasible in the current setting due to the limited number of years of analysis. ${ }^{6}$ A Herfindahl index computed at the audit partner level is unlikely to capture market concentration, because the client portfolios of single audit partners are relatively small. A concentration ratio measured at the audit partner level would therefore signal that audit markets are not concentrated regardless of the actual degree of market concentration.

Spatial analysis is used to determine the local markets in which local offices compete. The distances between local audit offices and both actual and potential clients are computed based on the geographical coordinates of local audit offices and clients. The coordinates of each local audit office are obtained at the city level. The coordinates for each audit client are based on their postal code. These coordinates are used to compute the geographical distances between every local audit office and every audit client within the sample.

Univariate analysis shows that $75 \%$ of the audited companies are within a 50 kilometer distance from their client. Therefore, a 50 kilometer range around a local office is expected to provide a reasonable estimation of the local market in which a local office operates. For each local office, the local audit market, $k$, is based on the number of clients within a 50 kilometer distance from the local office. ${ }^{7}$

Since audit fees are not publicly available in Belgium, this study relies on a proxy of auditor revenues to compute local office market shares. Market shares of local audit offices are needed to compute the Herfindahl indexes. Prior studies have used the natural logarithms of client revenues and client assets as proxies for audit fees (e.g. Simunic 1980; Hay et al. 2006). Sales revenue data for many small Belgian companies are not available in the BelFirst database. Using client sales revenues to proxy for audit fees would therefore result in the removal of a large part of the sample, creating a possible bias in the computation of the competition measures. The current study therefore uses the natural logarithm of client assets to proxy for audit fees.

$\mathrm{TA}_{\mathrm{ik}}$ equals the sum of the natural logarithms of total assets of all clients within local audit market $k$ that are audited by audit office $i$. TA $A_{k}$ equals the sum of the natural logarithms of total assets of all clients within local audit market $k$. Hence, the ratio $T A_{i k} / T A_{k}$ equals the proxy for the market share of each firm within local audit market $k$. The sum of the squared market shares of all auditors competing in local market $k$ equals the Herfindahl index of local audit market $k$ (HERFINDAHL ${ }_{k}$ ). A higher value of the Herfindahl index indicates that the market is more concentrated.

\subsubsection{Experimental variable: market share mobility}

The second measure of competition follows the mobility measure used by Buijink et al. (1998). Market share mobility captures auditor switches that are ignored by concentration measures, such as the Herfindahl index. A market share mobility measure is therefore used to measure competition as 
opposed to market concentration. This dynamic measure of market structure is computed based on the change in auditor market share from the previous to the current fiscal year. Changes in market share are more likely to occur in competitive markets than in less competitive audit markets (Yardley et al. 1992). Hence, market share mobility is positively associated with the level of competition.

The following model shows the computation of the absolute change in market share:

$$
\left|\Delta M S_{i t}\right|=\left|\frac{T A_{i t}}{T A_{t}}-\frac{T A_{i t-1}}{T A_{t-1}}\right|
$$

where:

\begin{tabular}{|c|c|c|}
\hline$\left|\Delta \mathrm{MS}_{i t}\right|$ & $=$ & $\begin{array}{l}\text { absolute value of the change in market share for auditor } \underline{i} \\
\text { in year } t \text {; }\end{array}$ \\
\hline$i$ & $=$ & audit firm, local audit office, or audit partner; \\
\hline$t$ & $=$ & year, $t-1$ refers to the previous year; \\
\hline $\mathrm{TA}_{i t}$ & $=$ & $\begin{array}{l}\text { the sum of the natural logarithms of total assets of all } \\
\text { clients that are audited by auditor } i \text { (i.e. audit firm, local } \\
\text { audit office, or audit partner); and }\end{array}$ \\
\hline $\mathrm{TA}_{t}$ & $=$ & $\begin{array}{l}\text { the sum of the natural logarithms of total assets of all } \\
\text { clients in the Belgian audit market. }\end{array}$ \\
\hline
\end{tabular}

Whereas Buijink et al. (1998) compute market share mobility at the national level, the current study measures market share mobility measure at the audit firm level, the local office level, and the audit partner level. ${ }^{8}$ The computation of this measure requires auditor information for both the current and the prior fiscal year. Since these data are not available for all observations, the effect of this competition measure is examined using the reduced sample of 59,353 observations (sample D).

The market share of auditor $i$ for year $t\left(\mathrm{MS}_{i t}\right)$ is computed as the sum of the natural logarithms of total assets of clients audited by auditor $i$, divided by the sum of the natural logarithms of total assets of all audited companies in Belgium during year $t$. The market share of auditor $i$ in year $t-1\left(\mathrm{MS}_{i t-1}\right)$ is computed in a similar manner.

This study uses the absolute change in market share to measure the competition faced by an auditor, as opposed to the signed change in market share, because a signed change in market share can be interpreted as a measure of performance (i.e. better performing auditors are more likely to gain market share, and vice versa). Absolute changes in market share are used to control for the performance effect.

\subsubsection{Experimental variable: competitor density}

Auditors face different competitors for each client due to the geographical dispersion of local audit partners and audit clients. Hence, there is a different set of potential auditors for each audit client within a local audit market. The previously discussed measures of competition, the Herfindahl index and market share mobility, do not take this into account, and may therefore not accurately reflect the level of competition in local audit markets. To overcome this problem, this paper introduces a new measure to capture 
local competition: COMPETITOR_DENSITY ${ }_{k}$. This measure incorporates both actual and potential auditor-client combinations within a local audit market. It furthermore takes into account that audit clients within a local market face different competitors due to their geographical locations.

Competitor density is measured at the audit partner level and is based on the number of audit partners and audit clients that compete in a local market. In doing so, this measure implicitly accounts for local office size, which is related to the office's audit capacity. Since audits of financial statements are labor intensive, the number of audit partners is a direct measure of capacity (Buijink et al. 1998). Competitor density measured at the audit partner level therefore provides a better approximation of local competition than competitor density measured at the local office level. ${ }^{9}$

Local competitor density is computed as follows:

COMPETITOR_DENSITY $_{k}=\frac{\sum_{i=1}^{N} \frac{\sum \text { TA_CLIENTS }_{i k}}{\sum_{\text {TA_CLIENTS }}}}{\# C L I E N T S_{k}}$

where:

\begin{tabular}{|c|c|c|}
\hline $\begin{array}{l}\text { COMPETITOR_DENSITY } \\
k \\
i\end{array}$ & & $\begin{array}{l}\text { measure of competition in local audit market } k \text {; } \\
\text { local audit market; } \\
\text { audit partner that, given his geographical location, is } \\
\text { able to compete for clients in local market } k \text {; }\end{array}$ \\
\hline$\sum$ TA_CLIENTS $_{i k}$ & $=$ & $\begin{array}{l}\text { able to compete for clients in local market } k \text {; } \\
\text { The sum of the natural logarithms of assets for all } \\
\text { clients in local market } k \text { that can potentially be audited } \\
\text { by audit partner } i \text {; }\end{array}$ \\
\hline$\sum$ TA_CLIENTS & & $\begin{array}{l}\text { The sum of the natural logarithms of assets for all } \\
\text { clients in local market } k \text {; and }\end{array}$ \\
\hline LIENT & & number of potential clients in local audit market $k$. \\
\hline
\end{tabular}

The construction of the local competitor density measure requires defining local audit markets. For each audit partner in Belgium, a local market $k$ is defined based on the location of the local audit office for which he works. First of all, all actual and potential clients within a 50 kilometer distance from the local office are identified. ${ }^{10}$ Second, for each client within this local audit market, it is examined which audit partners can audit this client. The number of competing audit partners is computed as the number of audit partners within a 50 kilometer distance of that client, under the constraint that the client is not more than 10 percent larger than the largest client currently within the portfolio of the local office for which the audit partner works. ${ }^{11}$

For each audit partner that can audit at least one client in local market $k$, a ratio is computed as the sum of the natural logarithms of client assets that this auditor could audit ( $\Sigma$ TA_CLIENTS $S_{i k}$ ), divided by the sum of the natural logarithms of assets of all clients in audit market $k$ ( $\Sigma$ TA_CLIENTS $k$ ). This ratio reflects an estimation of the percentage of audit fees of the total market for which each audit partner can compete.

The sum of these ratios for all audit partners that compete on local market $\mathrm{k}$ can be interpreted as an equivalent of the number of audit partners that can compete on all clients on local market $k$. This sum is subsequently 
divided by the sum of the number of actual and potential clients within local market $k$ (\#CLIENTS ${ }_{k}$ ) to create a measure of competitor density for local market $k^{12}$ COMPETITOR_DENSITY $k$ is positively associated with the degree of competition in a local market.

\subsubsection{Control variables}

Following prior literature, additional client-specific explanatory variables are included to control for their potential effect on discretionary accruals (e.g. Becker 1998; Reynolds and Francis 2001; Hunt and Lulseged 2007; Carey and Simnett 2006; Coulton and Ruddock 2007; Coulton, Ruddock and Taylor 2007; Knechel and Vanstraelen 2007; Francis and Yu 2009).

A dichotomous measure of audit firm size, BIGN, is included to control for the possibility that Big $\mathrm{N}$ audit firms provide higher quality audits due to reputation concerns (e.g. DeAngelo 1981b) or economies of scale (e.g. Johnson et al. 2002). This variable equals one if the company is audited by one of the Big N audit firms, 0 otherwise. ${ }^{13} \mathrm{~A}$ negative association between BIGN and ABSDACC is expected. ${ }^{14}$

Publicly traded companies differ from privately held companies in their incentives to manage earnings. The dummy variable LISTED indicates whether a company is listed on the Belgian stock exchange or not. Companies that are listed on a stock exchange may face pressure to manage earnings upwards in order to meet or beat earnings targets or analyst forecasts (Beatty et al. 2002; Fischer and Stocken 2004). However, potential litigation costs and reputation losses are larger for listed companies, creating an incentive for auditors to constrain earnings management more for listed companies than for private companies (Chaney et al, 2004; Vander Bauwhede and Willekens 2004). Evidence about differences in earnings management between public and private companies is mixed (e.g. Beatty et al. 2002; Vander Bauwhede et al. 2003; Burgstahler et al. 2006). Therefore, no expectation is expressed regarding the sign of LISTED.

Cash flow from operations scaled by total assets (CFO) is included because accruals and cash flows are found to be negatively correlated (Dechow 1994; Sloan 1996). A negative association between CFO and discretionary accruals is therefore expected.

The control variables LEVERAGE and PBANK are included to control for differences in earnings management incentives related to client leverage and financial distress. Based on the bankruptcy prediction model developed by Ooghe and Verbaere (1982), companies with an increased bankruptcy risk have a value of 1 for PBANK, 0 otherwise. ${ }^{15}$ Companies with high leverage or high bankruptcy risk can use asset write-offs to signal to lenders that they are committed to streamlining operations (DeAngelo et al. 1994) and to signal the need for wage concessions to unions (Liberty and Zimmerman 1986; DeAngelo and DeAngelo 1991). More highly leveraged firms and firms in distress may, on the other hand, also have more incentives to manage earnings upwards to meet debt covenants or avoid liquidation (DeFond and 
Jiambalvo 1994, Reynolds and Francis 2001). It is therefore not clear what the net effects of LEVERAGE and PBANK on discretionary accruals are.

The amount of discretionary accruals is expected to be positively associated with a company's growth opportunities (GROWTH), measured as the change in total assets (Johnson et al. 2002, Carey and Simnett 2006; Hunt and Lulseged 2007).

Client company size (SIZE) is correlated with operating characteristics which reduce the absolute amounts of discretionary accruals (Reynolds and Francis 2001). A negative coefficient of SIZE is therefore expected. Company size is measured as the natural log of total asset, with client assets stated in thousands of Euros.

Younger companies are more likely to experience financial distress (Carey and Simnett 2006), increasing the pressure to manage earnings. Company age (LN_AGE) is computed as the natural logarithm of the number of years since the formation of the company obtained from the Bel-First database. A negative coefficient of LN_AGE is expected.

Companies which report operating losses are found to be less likely to report future earnings surprises (Brown 2001). A control variable, LOSS, is therefore included to control for the possible effect of reporting a loss on audit quality. LOSS has a value of 1 if the company reported an operating loss in the prior year, 0 otherwise. A negative association between LOSS and discretionary accruals is expected.

Finally, to control for possible year effects, year dummies for all except the first year are included.

\subsubsection{Regression models}

This section presents the regression models that are used to examine the effect of competition on audit quality.

\subsubsection{Regression model: the effect of market concentration on audit quality} The model displayed below is used to test the effect of market concentration, measured using the HERFINDAHL index, on audit quality. The dependent variable of this model is derived from the modified Jones model as explained in section 3.2. The absolute value of discretionary accruals is used, because clients can manage earnings either upwards or downwards depending on their circumstances (Warfield et al. 1995).

$$
\begin{aligned}
& \text { ABSDACC }=\beta_{0}+\beta_{1} \text { HERFINDAHL }+\beta_{2} \text { PBANK }+\beta_{3} \text { LISTED }+ \\
& \beta_{4} \text { LN_AGE }+\beta_{5} \text { CFO }+\beta_{6} \text { LEV }+\beta_{7} \text { GROWTH }+\beta_{8} \text { BIGN }+ \\
& \beta_{9} \text { SIZE }+\beta_{10} \text { LOSS }+\sum_{11}^{18} \beta_{i} \text { YEAR_DUMMIES }+\epsilon .
\end{aligned}
$$

where:

ABSDACC

HERFINDAHL

PBANK
$=$ absolute value of discretionary accruals scaled by lagged total assets;

$=$ Herfindahl score for the local market $k$ defined as the potential clients within a 50 kilometer distance from the local audit office;

$=1$ if the client has a high risk of going bankrupt, based on the bankruptcy prediction model by Ooghe and Verbaere 
LISTED

LN_AGE

CFO

LEV

GROWTH

BIGN

SIZE

LOSS

YEAR_DUMMIES
(1982), and 0 otherwise;

$=1$ if the client is listed on the Belgian stock exchange, and 0 otherwise;

$=$ natural logarithm of the company age measured in years;

$=$ cash flow from operations, scaled by beginning of the year total assets; ${ }^{16}$

$=\quad$ total liabilities divided by total assets;

$=$ growth in total assets from the previous to the current fiscal year;

$=1$ if the client is audited by one of the Big $\mathrm{N}$ audit firms, and 0 otherwise;

$=$ natural logarithm of total assets of the client company $(€ 000)$ at fiscal year-end;

$=1$ if the operating income of the client was negative in the prior fiscal year, and 0 otherwise; and

$=\quad$ one dummy variable per year, for the years 1999-2006.

The remaining variables are defined as earlier.

This regression model is estimated using the sample of 90,529 observations (sample C), which is the largest sample size available for the regression analysis given the data requirements.

\subsubsection{Regression model: the effect of market share mobility on audit quality} The effect of the absolute values of changes in market shares on changes in absolute discretionary accruals is tested using model (4.6). The delta variables in this model are computed by subtracting the prior year value of the observations from the current year value. The expected directions of the change variables are similar to those explained for model (4.5). No change variable is included for company age, as the change in age is always equal to one year. Furthermore, $\triangle$ LISTED is not included because of the limited number of observations that experienced a change in stock listing status. Year dummies are included to control for possible year effects.

$$
\begin{aligned}
& \Delta \mathrm{ABSDACC}=\beta_{0}+\beta_{1}|\Delta \mathrm{MS}|+\beta_{2} \Delta \mathrm{PBANK}+\beta_{3} \Delta \mathrm{CFO}+\beta_{4} \Delta \mathrm{LEV}+ \\
& \beta_{5} \Delta \mathrm{GROWTH}+\beta_{6} \Delta \mathrm{BIGN}+\beta_{7} \Delta \mathrm{SIZE}+\beta_{8} \Delta \mathrm{LOSS}+ \\
& \sum_{9}^{15} \beta_{i} \text { YEAR_DUMMIES }+\epsilon .
\end{aligned}
$$

where:

$\triangle$ ABSDACC

$|\Delta \mathrm{MS}|$

$\triangle$ PBANK

$\triangle$ LISTED

$\triangle \mathrm{CFO}$

$\Delta \mathrm{LEV}$

$\triangle$ GROWTH

$\triangle \mathrm{BIGN}$
$=$ the change in the absolute amount of discretionary accruals scaled by lagged total assets from year $t-1$ to year $t$;

$=\quad$ the absolute change in market share of the audit firm year $t$ 1 to year $t$, measured at three different levels: the audit firm level, the local office level, and the audit partner level:

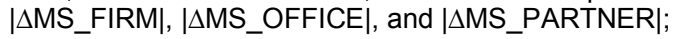

$=\quad$ change in the likelihood of bankruptcy (PBANK) from year $t$ 1 to year $t$;

$=$ change in stock exchange listing from year $t-1$ to year $t$,

$=$ change in cash flow from operations, scaled by beginning of the year total assets from year $t-1$ to year $t$;

$=\quad$ change in total liabilities divided by total assets from year $t-1$ to year $t$,

$=\quad$ change in the growth in total assets from year $t-1$ to year $t$;

$=\quad$ change in auditor size (Big N versus Non Big N) from year $t$ - 
$\triangle$ SIZE

$\Delta$ LOSS

YEAR_DUMMIES
1 to year $t$;

$=$ change in the natural logarithm of total assets of the client company $(€ 000)$ from year $t-1$ to year $t$;

$=\quad$ change in the profitability status of the client from year $t-2$ to year $t-1$; and

$=\quad$ one dummy variable per year, for the years 2000-2006.

This model is estimated using the 59,353 observations for which prior year data is available (sample D). Prior year data is required to compute the changes in value from the prior to the current year.

\subsubsection{Regression model: the effect of competitor density on audit quality}

The effect of competitor density on audit quality is tested based on the model displayed below. The experimental variable is COMPETITOR_DENSITY. The absolute amount of discretionary accruals is used to proxy for audit quality, similar to model (4.5).

$$
\begin{aligned}
& \text { ABSDACC }=\beta_{0}+\beta_{1} \text { COMPETITOR_DENSITY }+\beta_{2} \text { PBANK }+ \\
& \beta_{3} \text { LISTED }+\beta_{4} \text { LN_AGE }+\beta_{5} \text { CFO }+\beta_{6} \text { LEV }+\beta_{7} \text { GROWTH }+ \\
& \beta_{8} \text { BIGN }+\beta_{9} \text { SIZE }+\beta_{10} \text { LOSS }+\sum_{11}^{18} \beta_{i} \text { YEAR_DUMMIES }+\epsilon .
\end{aligned}
$$

where:

COMPETITOR_DENSITY = the ratio of the weighted number of competing audit partners divided by the number of potential clients in a local audit market.

The remaining variables are defined as earlier.

This model is estimated based on sample $C(n=90,529)$, which is the largest sample available for testing the effect of competitor density on audit quality.

\subsection{Descriptive statistics and results}

This section first presents the descriptive statistics. This is followed by an overview of the multivariate results, categorized per type of competition variable. A number of robustness checks conclude this section.

\subsubsection{Descriptive statistics}

Table 4.3 presents the descriptive statistics. The descriptive statistics for sample $C$ are shown in Panel A of Table 4.3. Panel B of Table 4.3 displays the descriptive statistics for sample D. Panel A shows that the estimated discretionary accruals are on average 12.5 percent of the beginning of the year total assets. This is in line with prior research (e.g. Reynold and Francis 2001). The Herfindahl index has a mean of 0.016, which according to the criteria posted by Shepherd (1990) is indicative of a loose oligopoly. The concentration ratio is lower than the concentration ratios commonly reported 
Table 4.3 - Panel A: Descriptive statistics for sample C, i.e. the sample for the regression analyses of models 5 and $7(n=90,529)$

\begin{tabular}{|c|c|c|c|c|c|}
\hline Variables & Mean & Median & Std. Dev. & Minimum & Maximum \\
\hline$\overline{\mathrm{DACC}}$ & $\overline{.000}$ & .007 & .188 & -.692 & .624 \\
\hline ABSDACC & .125 & .075 & .141 & .000 & .692 \\
\hline HERFINDAHL & .016 & .016 & .004 & .009 & .030 \\
\hline COMPETITOR_DENSITY & .050 & .044 & .018 & .033 & .148 \\
\hline PBANK & .296 & 0 & .456 & 0 & 1 \\
\hline LISTED & .003 & 0 & .058 & 0 & 1 \\
\hline AGE & 23.124 & 18 & 16.946 & 2 & 83 \\
\hline CFO & .098 & .080 & .228 & -.734 & .940 \\
\hline LEV & .640 & .686 & .267 & .015 & 1 \\
\hline GROWTH & .091 & .024 & .440 & -.810 & 3.936 \\
\hline BIGN & .453 & .498 & .498 & 0 & 1 \\
\hline ASSETS (IN € THOUSANDS) & $21,580.150$ & 5,280 & $65,469.350$ & 4.000 & $538,104.000$ \\
\hline LOSS & .072 & 0 & .259 & 0 & 1 \\
\hline \multicolumn{6}{|c|}{$\begin{array}{l}\text { - All variables are winsorized at the top and bottom } 1 \% \text {. } \\
\text { - Variable definitions: }\end{array}$} \\
\hline $\begin{array}{l}\text { DACC } \\
\text { ABSDACC } \\
\text { HERFHINDAHL }\end{array}$ & \multirow{11}{*}{\multicolumn{5}{|c|}{$\begin{array}{l}=\text { amount of discretionary accruals scaled by lagged total assets } \\
=\text { absolute amount of discretionary accruals scaled by lagged total assets } \\
=\text { Herfindahl score for the local market, defined based on the clients within a } \\
50 \text { kilometer distance from the local audit office } \\
=\text { the ratio of the weighted number of competing audit partners divided by } \\
\text { the number of potential clients in the local audit market, defined as the } \\
\text { potential clients within a } 50 \text { kilometer distance from the local audit office. } \\
=1 \text { if the client has a high risk of going bankrupt, based on the bankruptcy } \\
\text { prediction model by Ooghe and Verbaere (1982), and } 0 \text { otherwise } \\
=1 \text { if the client is listed on the Belgian stock exchange, and } 0 \text { otherwise } \\
=\text { company age measured in number of years } \\
=\text { cash flow from operations, scaled by beginning of the year total assets } \\
=\text { total liabilities divided by total assets } \\
=\text { growth in total assets from year } \mathrm{t}-1 \text { to year } t \\
=1 \text { if the client is audited by one of the Big } \mathrm{N} \text { audit firms, and } 0 \text { otherwise } \\
=\text { total assets of the client company ( }(000) \text { at fiscal year-end } \\
=1 \text { if the operating income of the client was negative in the prior fiscal year, } \\
\text { and } 0 \text { otherwise }\end{array}$}} \\
\hline COMPETITOR_DENSITY & & & & & \\
\hline PBANK & & & & & \\
\hline LISTED & & & & & \\
\hline & & & & & \\
\hline CFO & & & & & \\
\hline & & & & & \\
\hline GROWTH & & & & & \\
\hline BIGN & & & & & \\
\hline ASSETS & & & & & \\
\hline LOSS & & & & & \\
\hline
\end{tabular}

in prior studies conducted in the U.S. (e.g. Tomczyk and Read 1989). The lower market concentration is, at least partially, a result of the sample selection. The aggregate market share of the dominant firms is positively associated with the size of audit clients (Dopuch and Simunic 1980). Hence, market concentration can be expected to be lower in a setting which includes not only listed, but also non-listed companies which are generally smaller than listed companies.

Panel B of Table 4.3 shows that |DMS_FIRM| has a mean value of .004 , indicating that market shares of audit firms change on average by 0.4 percent of the total Belgian audit market in a single year. The values for $\mid \triangle \mathrm{MS}$ OFFICE| (0.2 percent) and |SMS_PARTNER| (0.004 percent) are naturally lower, since the market shares are computed at a national level. Furthermore, the Table 4.shows that the largest change in market share within one year was 3.6 percent for an audit firm, 1.4 percent for a local audit office, and 0.2 percent for an audit partner. COMPETITOR_DENSITY has a mean of .050 , and ranges from .033 to .148, indicating that there are large differences in competition across local audit markets.

Regarding the control variables, Panel A of Table 4.3 indicates that 29.6 percent of the companies in the sample had an increased risk of bankruptcy, and that 0.3 percent of the companies were listed on the Belgian stock exchange. The average company age is just over 23 years and ranges 
Table 4.3 - Panel B: Descriptive statistics for sample D, i.e. the sample for the change regressions of model $6(n=59,353)$

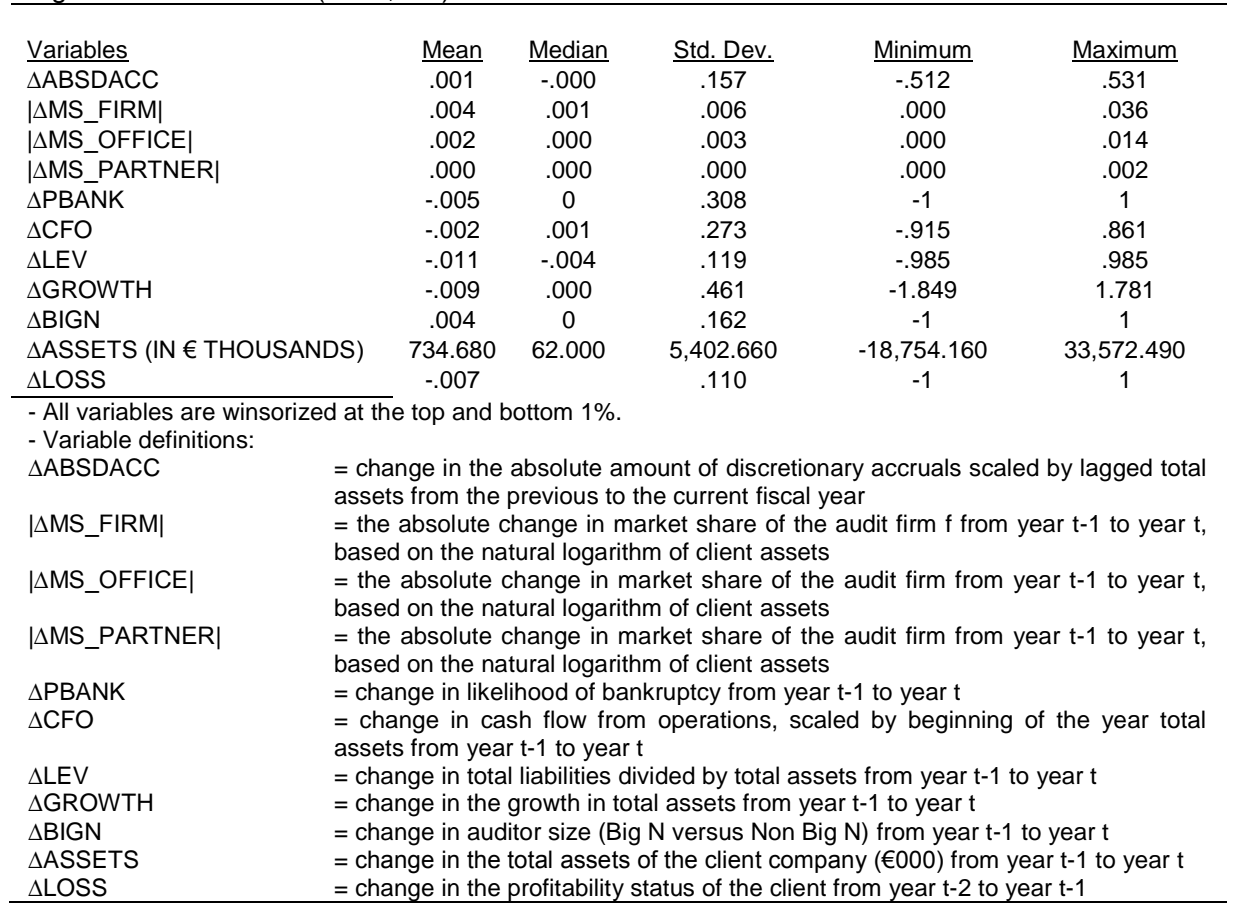

between 2 and 83 years. Cash flows from operations are on average equal to $9.8 \%$ of beginning of the year assets. Companies in the sample have on average a leverage of 64 percent. The average company size, measured in assets, is 21.6 million euro. The average growth in assets is 9.1 percent. 45.3 percent of the companies in the sample are audited by Big $N$ audit firms. Finally, the descriptive statistics indicate that 7.2 percent of the companies had an operating loss in the prior year.

Furthermore, from Panel B of Table 4.3 follows that the mean value of $\triangle$ PBANK is -.005 , indicating that the risk of bankruptcy decreased slightly over the sample period. The mean value of $\triangle$ CFO is negative (-.002), showing that cash flows from operations became smaller relative to beginning of the year total assets. Leverage (-.011) and asset growth (-.009) also decreased over the sample period. The market share of Big $\mathrm{N}$ audit firms increased during the period of analysis, on average by $0.4 \%$ per year. The average annual increase in client size equals 1.319 million euro. Finally, $\Delta$ LOSS has a negative value $(-.007)$, suggesting that clients became more likely to report profits.

The correlation matrices are shown in Table 4.4. Panel A of Table 4.4 shows the correlation matrix for the variables in models (4.5) and (4.7), based on sample C. Panel B of Table 4.4 shows the correlation matrix for sample D. This panel includes the variables stated in model (4.6). Most of the correlations between variables are significant, but low. Only the correlations between the competition variables are high, but those variables 
are not simultaneously included in the model. Correlation between competition variables is therefore not an issue. Variance inflation factors (VIF) reported with the regression outputs suggest that multicollinearity of the explanatory variables is not of concern.

The Pearson correlation between HERFINDAHL and ABSDACC is significant and negative, providing some preliminary evidence that audit quality is higher in more concentrated audit markets. However, the Spearman correlation between HERFINDAHL and ABSDACC is insignificant. No preliminary evidence is found of an association between market share mobility and audit quality. The significantly negative Pearson and Spearman correlations between COMPETITOR_DENSITY and ABSDACC suggest that competition and audit quality are positively associated. This provides preliminary evidence in support of the hypothesis.

\subsubsection{Multivariate results}

Ordinary least squares regressions with robust standard errors are estimated to test the hypothesis. Robust standard errors, clustered per audit firm, are reported because the sample includes multiple observations per audit firm per year, which violates the assumption that observations are independent.

This section provides an overview of the multivariate results for each of the experimental variables.

\subsubsection{Multivariate results: Herfindahl index}

The first regression analysis (model (4.5)) estimates the effect of concentration, measured using the Herfindahl index, on absolute discretionary accruals. Results are shown in Table 4.5. The model has an adjusted $R^{2}$ of 14.94 percent and an F-value of 659.31 , which indicate that the model fits the data well and explains a reasonable amount of the variation in the dependent variable. The reported adjusted $R^{2}$ is in line with values reported in prior research (e.g. Reynolds and Francis 2001; Kallapur et al. 2008). The coefficient for HERFINDAHL is negative and significant ( $\beta=$ $-.846, p<.01)$. This suggests that absolute discretionary accruals are lower in local markets which are more concentrated. This suggests that audit quality is higher in more concentrated local audit markets. This finding is consistent with the results reported by Kallapur et al. (2008). Following the commonly argued negative association between market concentration and competition, the results may suggest that there is a negative association between competition and audit quality. However, it is important to note that prior studies have questioned whether concentration measures capture competition (Yardley et al. 1992; Pearson and Trompeter 1994; Buijink et al. 1998).

The coefficient of control variable PBANK $(\beta=.019, p<.01)$ indicates that client earnings management is higher when clients have an increased bankruptcy risk, consistent with the argument that poorly performing companies have increased incentives to manage earnings. This is in line with prior research (e.g. DeAngelo et al. 1994). The coefficient of the second control variable, LISTED, $(\beta=.022, p<0.01)$ indicates that listed companies 


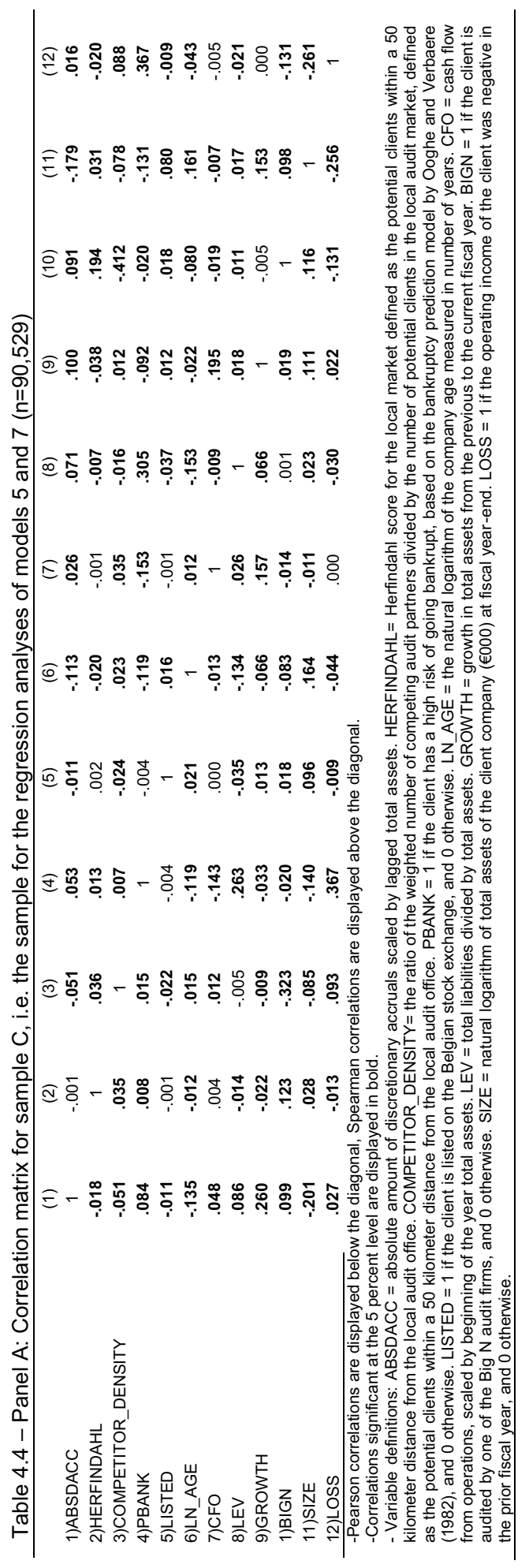




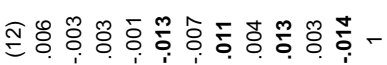

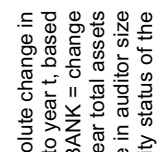

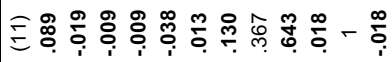

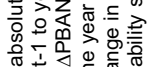

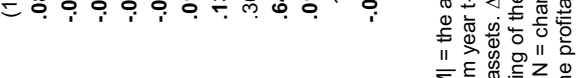

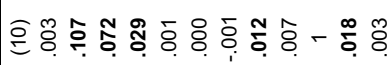

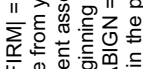

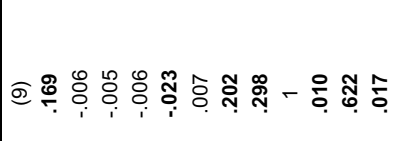

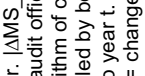

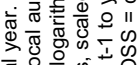

กิ

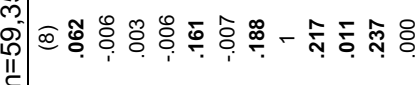

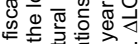

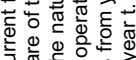

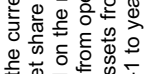

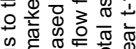

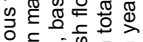

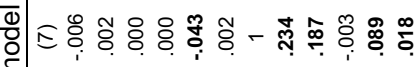

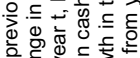

๑

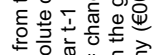

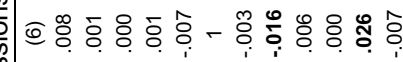

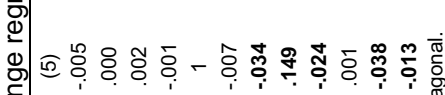

ปั

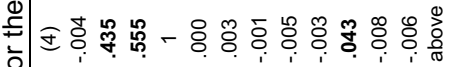

密

$\stackrel{\oplus}{=}$

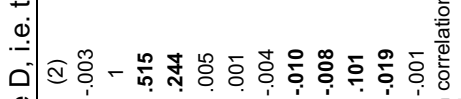

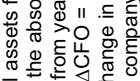

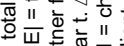

엉후

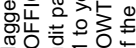

定w

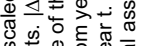

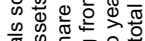

焉品

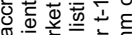

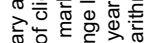

흘 등흔 틍을

它额

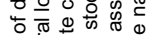

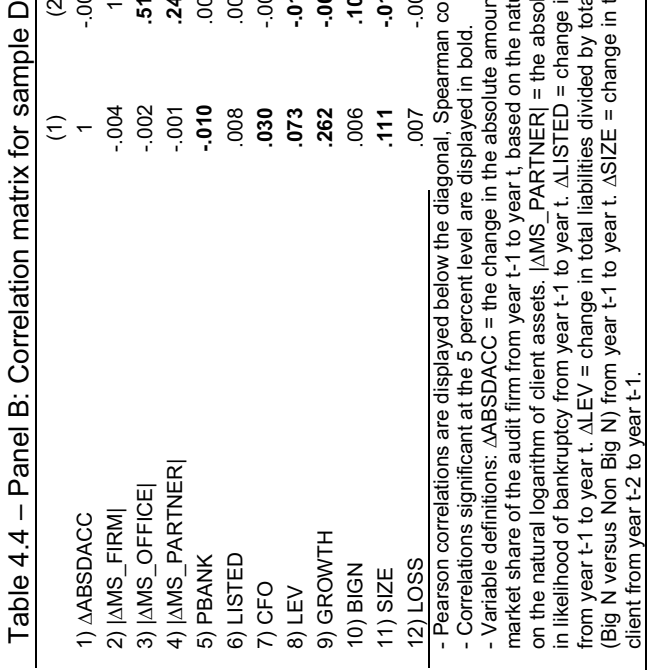


Table 4.5: Cross-sectional regression model for the absolute discretionary accruals. The experimental variable is HERFINDAHL. Results are based on sample C, i.e. the sample for regression analyses $(n=90,529)$.

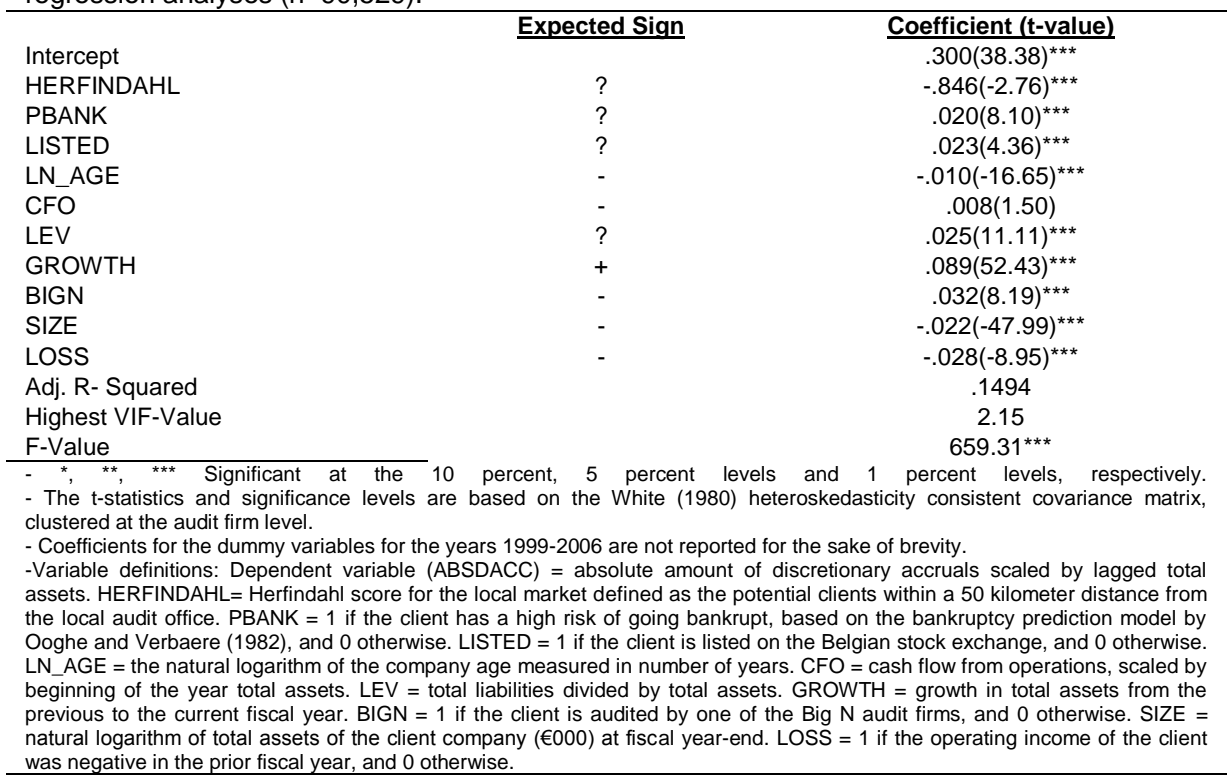

engage more in earnings management behavior than non-listed companies. The coefficient of control variable LN_AGE $(\beta=-.010, p<0.01)$ indicates that older firms show less earnings management behavior than younger firms. The fourth control variable, CFO, has a positive, but insignificant coefficient $(\beta=.008, p>.10)$, which indicates that there is no relationship between the size of operating cash flows and earnings management. Higher leverage, LEV $(\beta=.026, p<.01)$, is significantly associated with increased earnings management, which is consistent with the findings by DeFond and Jiambalvo 1994. GROWTH has a positive and significant coefficient $(\beta=.090$, $\mathrm{p}<.01$ ), which indicates that client growth has a positive association absolute discretionary accruals. Hence, growing companies appear to engage more in earning management than more stable companies. Contrary to expectations, BIGN has a positive and significant coefficient $(\beta=.025, p<.01)$, which indicates that Big $N$ audit firms allow clients more discretion to manage earnings than non-Big $\mathrm{N}$ audit firms. This effect is in contrast with the commonly reported finding that Big $\mathrm{N}$ auditors provide higher audit quality than non-Big $\mathrm{N}$ auditors (e.g. Becker et al. 1998). This finding, however, is in line with other studies that reported mixed evidence on an audit quality difference between Big $\mathrm{N}$ and non-Big $\mathrm{N}$ audit firms in the European private client segment (e.g. Gaeremynck and Willekens 2003; Vander Bauwhede and Willekens 2004). The coefficient of the control variable SIZE is negative and significant $(\beta=-.022, p<.01)$, which shows that the absolute level of discretionary accruals is negatively associated with the size of the audited company. Finally, the coefficient of LOSS $(\beta=-.027, p<.01)$ is negative and 
Table 4.6: Cross-sectional regression model for the change in absolute discretionary accruals. The experimental variables are absolute values of the changes in market share measured at the audit firm level, the local audit office level and the audit partner level. Results are based on sample D, i.e. the sample for change regressions $(n=59,353)$.

\begin{tabular}{|c|c|c|c|c|}
\hline & & $\begin{array}{l}\text { (1) Audit Firm } \\
\text { Level }\end{array}$ & $\begin{array}{l}\text { (2) Local Office } \\
\text { Level }\end{array}$ & $\begin{array}{l}\text { (3) Audit Partner } \\
\text { Level }\end{array}$ \\
\hline Variables & $\frac{\text { Expected }}{\text { Sign }}$ & $\frac{\text { Coefficient (t- }}{\text { value) }}$ & $\frac{\text { Coefficient (t- }}{\text { value) }}$ & $\frac{\text { Coefficient (t- }}{\text { value) }}$ \\
\hline$\overline{\text { Intercept }}$ & & $.006(2.50)^{\star \star}$ & $.006(2.33)^{\star \star}$ & $.006(2.41)^{\star \star}$ \\
\hline | $\Delta \mathrm{MS}$ FIRM| & $?$ & $-.130(-2.84)^{\star * *}$ & & \\
\hline | $\triangle \mathrm{MS} \_O F F I C E \mid$ & $?$ & & $-.112(-1.00)$ & \\
\hline | $\triangle \mathrm{MS} \_$PARTNER| & $?$ & & & $-.478(-.58)$ \\
\hline$\triangle \mathrm{PBANK}$ & $?$ & $-.006(-2.11)^{\star \star}$ & $-.006(-2.11)^{\star *}$ & $-.006(-2.11)^{\star \star}$ \\
\hline$\triangle \mathrm{CFO}$ & - & $-.017(-3.71)^{\star \star \star}$ & $-.017(-3.72)^{\star \star \star}$ & $-.017(-3.72)^{\star \star \star}$ \\
\hline$\Delta \mathrm{LEV}$ & $?$ & $.045(5.13)^{\star * \star}$ & $.045(5.13)^{\star \star \star}$ & $.045(5.13)^{\star * *}$ \\
\hline$\triangle$ GROWTH & + & $.108(47.19)^{\star \star \star}$ & $.108(47.24)^{\star \star *}$ & $.108(47.24)^{\star \star \star}$ \\
\hline & - & $.004(1.23)$ & $.004(1.16)$ & $.004(1.14)$ \\
\hline & - & $-.040(-16.21)^{\star \star *}$ & $-.040(-16.22)^{\star \star *}$ & $-.040(-16.23)^{\star \star \star}$ \\
\hline$\Delta$ LOSS & - & $.000(.07)$ & $.000(.07)$ & $.000(.07)$ \\
\hline Adj. R- Squared & & .0750 & .0750 & .0750 \\
\hline Highest VIF-Value & & 1.97 & 1.97 & 1.97 \\
\hline F-Value & & $291.71^{* * *}$ & $289.19^{\star * *}$ & $288.51^{* * *}$ \\
\hline \multicolumn{5}{|c|}{ 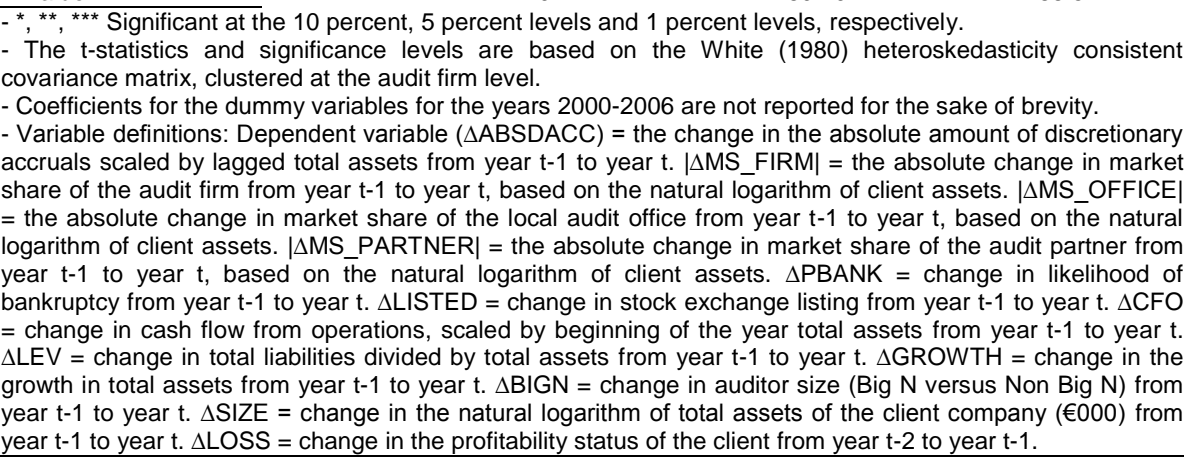 } \\
\hline
\end{tabular}

significant, which indicates that firms that have had an operating loss in the prior year have lower absolute discretionary accruals in the current year.

\subsubsection{Multivariate results: market share mobility}

Table 4.6 reports the results of the estimation of regression model (4.6), in which changes in absolute discretionary accruals are regressed on absolute changes in market shares. The table includes three columns, one for each level of analysis, i.e. the audit firm, the local office and the audit partner level. The adjusted R-squares for each of the three regressions equal 7.50 percent. The F-values are all above 288.51. Although the reported Rsquares are lower than the R-square reported for the Herfindahl index, the models still seem to fit the data well. The coefficient for the $\mid \Delta M S$ FIRM $\mid$ is negative and significant $(\beta=-.130, p<.01)$. This suggests that audit firms which face increased competition provide higher audit quality. The coefficients for $\mid \Delta$ MS_OFFICE $\mid(\beta=-.112, p>.10)$ and $\left|\Delta M S \_P A R T N E R\right|(\beta=$ -.478, $p>$.10) are however not significant, possibly because changes in market shares at these levels are small. This finding that increased competition faced by audit firms results in higher audit quality is consistent 
with results reported by Copley and Doucet (1993) and Johnstone and Bedard (2003). Hence, the results provide limited support for the hypothesis that there is an association between competition and audit quality. The results also suggests that an analysis based on a concentration ratio does not necessarily provide the same results as an analysis based on a measure of competition. While the findings reported in Table 4.5 show a positive association between the Herfindahl index and audit quality, the results of market share mobility reported in Table 4.6 suggest that competition is positively associated with audit quality. Hence, the use of a concentration ratio as a proxy for competition can lead to wrong conclusions.

With respect to the control variables, the results shown in Table 4.6 suggest that companies facing an increased bankruptcy risk experience a decrease in absolute discretionary accruals. This is opposite to the effect reported in the previous regression analysis.

Whereas the effect of operating cash flows on earnings management was insignificant in the prior regression, the results of the change regressions indicate that increases in operating cash flows are associated with decreases in earnings management. Firms changing from a non-Big $\mathrm{N}$ to a Big $\mathrm{N}$ auditor, and vice versa, do not seem to experience a change in reported absolute discretionary accruals. The effects of the remaining control variables are consistent with those reported in Table 4.5.

\subsubsection{Multivariate results: competitor density}

Table 4.7 shows the results for regression model (4.7), with COMPETITOR_DENSITY as the experimental variable. The model has an adjusted $R^{2}$ of 14.97 percent. The model $F$-value equals 654.51. The coefficient of COMPETITOR_DENSITY is negative and significant $(\beta=-.218$, $\mathrm{p}<.01)$. This suggests that increased local competition is associated with lower levels of absolute discretionary accruals (ABSDACC), hence higher audit quality. This result is in line with the findings reported in Table 4.6, which show a negative association between market share mobility at the firm level and a change in client earnings management. Hence, the results based on competitor density suggest that audit quality is higher in more competitive audit markets. These findings provide further support for the hypothesis. Additionally, this provides further evidence that the locally defined Herfindahl index does not reflect local competition. ${ }^{17}$

The effects of the control variables are consistent with those reported in Table 4.5. 
Table 4.7: Cross-sectional regression model for absolute discretionary accruals. The experimental variable is COMPETITOR_DENSITY. Results are based on sample C, i.e. the sample for regression analyses $(n=90,52 \overline{9})$

\begin{tabular}{|c|c|c|}
\hline & Expected Sign & Coefficient (t-value) \\
\hline Intercept & & $.300(57.79)^{\star \star \star}$ \\
\hline COMPETITOR_DENSITY & ? & $-.218(-4.35)^{\star \star \star}$ \\
\hline PBANK & $?$ & $.020(7.97)^{\star \star *}$ \\
\hline LISTED & $?$ & $.022(4.18)^{\star \star \star}$ \\
\hline LN_AGE & - & $-.010(-16.30)^{\star * *}$ \\
\hline CF- & - & $.008(1.48)$ \\
\hline LEV & ? & $.025(11.03)^{\star \star \star}$ \\
\hline GROWTH & + & $.089(53.12)^{* * *}$ \\
\hline BIGN & - & $.029(6.65)^{\star \star \star}$ \\
\hline SIZE & - & $-.022(-49.87)^{\star * *}$ \\
\hline LOSS & - & $-.027(-8.83)^{\star \star \star}$ \\
\hline Adj. R- Squared & & .1497 \\
\hline Highest VIF-Value & & 1.97 \\
\hline Model F-Value & & $654.51^{\star \star \star}$ \\
\hline \multicolumn{3}{|c|}{$\begin{array}{l}-{ }^{*},{ }^{* *},{ }^{* * *} \text { Significant at the } 10 \text { percent, } 5 \text { percent levels and } 1 \text { percent levels, respectively. } \\
- \text { The } t \text {-statistics and significance levels are based on the White }(1980) \text { heteroskedasticity consistent covariance matrix, } \\
\text { clustered at the audit firm level. } \\
\text { - Coefficients for the dummy variables for the years } 1999-2006 \text { are not reported for the sake of brevity. } \\
- \text { Variable definitions: Dependent variable (ABSDACC) }=\text { absolute amount of discretionary accruals scaled by lagged total } \\
\text { assets. COMPETITOR_DENSITY }=\text { the ratio of the weighted number of competing audit partners divided by the number of } \\
\text { potential clients in the local audit market, defined as the potential clients within a } 50 \text { kilometer distance from the local audit } \\
\text { office. PBANK }=1 \text { if the client has a high risk of going bankrupt, based on the bankruptcy prediction model by Ooghe and } \\
\text { Verbaere }(1982), \text { and } 0 \text { otherwise. LISTED }=1 \text { if the client is listed on the Belgian stock exchange, and } 0 \text { otherwise. LN_AGE }= \\
\text { the natural logarithm of the company age measured in number of years. CFO }=\text { cash flow from operations, scaled by beginning } \\
\text { of the year total assets. LEV = total liabilities divided by total assets. GROWTH = growth in total assets from the previous to the } \\
\text { current fiscal year. BIGN }=1 \text { if the client is audited by one of the Big } N \text { audit firms, and } 0 \text { otherwise. SIZE }=\text { natural logarithm of } \\
\text { total assets of the client company }(€ 000) \text { at fiscal year-end. LOSS }=1 \text { if the operating income of the client was negative in the } \\
\text { prior fiscal year, and } 0 \text { otherwise. }\end{array}$} \\
\hline
\end{tabular}

\subsubsection{Multivariate results: summary}

In this section, the effect of competition in the market for audit services on audit quality was examined using three different measures of competition. The regression results based on the locally defined Herfindahl index suggest that audit quality is positively related to local market concentration. The regression based on the measure of absolute values of changes in firm market shares suggests a positive association between competition at the audit firm level and audit quality. However, no effect of market share mobility on audit quality is found at the local office level and the audit partner level. The insignificant effects of competition on audit quality at these levels can probably be explained by to the very small changes in market shares that occur at the local office and audit partner levels.

The results of the regression that examines the effect of competitor density on audit quality show a negative association between competitor density and absolute discretionary accruals. Hence, these results suggest that there is a positive association between audit quality and competition.

Overall, the results suggest that there is a positive association between competition and audit quality. Hence, there appears to be support for the hypothesis that there is an association between competition and audit quality. The results, furthermore, indicate that the locally defined Herfindahl index may not capture competition. This is in line with the findings by Buijink et al. (1998), who suggest that audit markets can be competitive despite high concentration levels. 
Table 4.8: Cross-sectional regression model for negative and positive discretionary accruals (dependent variable is absolute discretionary accruals scaled by lagged total assets). The experimental variable is HERFINDAHL. Results are based on sample C, i.e. the sample for regression analyses $(n=90,529)$.

\begin{tabular}{|c|c|c|c|}
\hline & & $\begin{array}{c}\text { Negative Discretionary } \\
\text { Accruals } \\
n=42,886\end{array}$ & $\begin{array}{c}\text { Positive Discretionary } \\
\text { Accruals } \\
n=47,643\end{array}$ \\
\hline & Expected Sign & Coefficient (t-value) & Coefficient (t-value) \\
\hline Intercept & & $.142(16.69)^{\star * \star}$ & $.292(39.61)^{\star * *}$ \\
\hline HERFINDAHL & $?$ & $-.527(-2.50)^{\star \star}$ & $-.536(-1.72)^{\star}$ \\
\hline PBANK & $?$ & $.060(14.87)^{* * *}$ & $-.019(-16.20)^{* * *}$ \\
\hline LISTED & $?$ & $.013(1.57)$ & $.030(2.75)^{\star \star \star}$ \\
\hline LN_AGE & - & $-.006(-7.83)^{* * *}$ & $-.008(-10.97)^{\star \star \star}$ \\
\hline CFO & - & $.421(57.13)^{* * *}$ & $-.396(-56.73)^{\star * *}$ \\
\hline LEV & $?$ & $.065(22.75)^{\star * *}$ & $-.011(-4.88)^{\star \star \star}$ \\
\hline GROWTH & + & $.033(11.94)^{* * *}$ & $.067(35.03)^{* * *}$ \\
\hline BIGN & - & $.021(8.49)^{* * *}$ & $.024(7.45)^{\star \star \star}$ \\
\hline SIZE & - & $-.018(-23.03)^{\star \star \star}$ & $-.018(-36.33)^{\star \star \star}$ \\
\hline LOSS & - & $-.038(-9.76)^{\star \star *}$ & $-.007(-2.79)^{\star * *}$ \\
\hline Adj. R- Squared & & .4723 & .4546 \\
\hline Highest VIF-Value & & 2.19 & 2.11 \\
\hline F-Value & & $1,325.51^{* \star *}$ & $1,597.41^{\star \star \star}$ \\
\hline \multicolumn{4}{|c|}{ 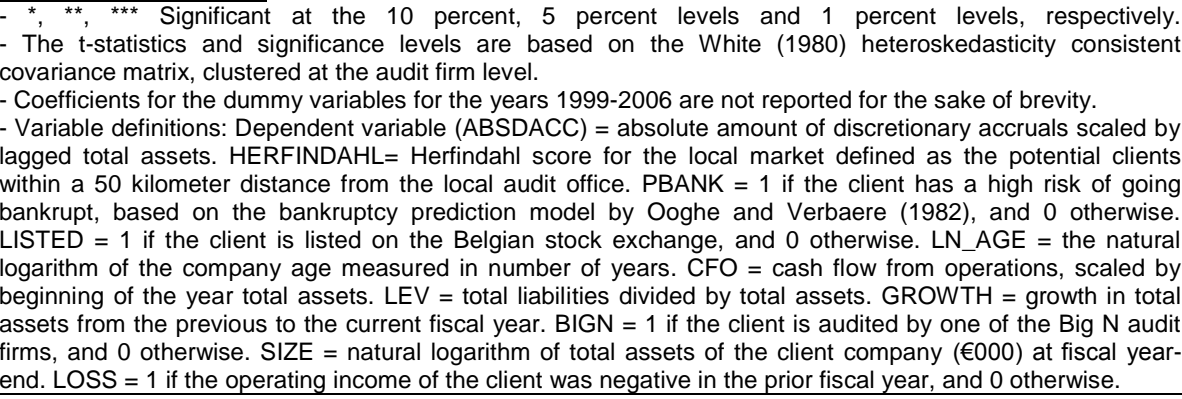 } \\
\hline
\end{tabular}

\subsubsection{Robustness checks}

This section analyzes the extent to which the results reported before are robust to the use of different proxies for audit quality and differences in sample selection.

\subsubsection{Income increasing versus income decreasing earnings management}

So far, audit quality has been proxied by the absolute amount of discretionary accruals. Using absolute discretionary accruals as a measure of audit quality makes sense, since clients can be expected to engage in either upward or downward earnings management based on their specific circumstances and auditors are expected to reduce both upward and downward earnings management (Warfield et al. 1995).

However, both clients and auditors face different incentives with respect to upward versus downward earnings management. Clients face incentives to manage earnings upwards in order to attract investors (Beatty et al. 2002; Fischer and Stocken 2004), while downward earnings management may be driven by tax reduction incentives (Vander Bauwhede and Willekens 2004; Ball and Shivakumar 2005). Tax authorities are mainly focused on preventing downward earnings management which is aimed at tax reduction 
Table 4.9: Cross-sectional regression model for negative and positive discretionary accruals (dependent variable is absolute discretionary accruals scaled by lagged total assets). The experimental variable is COMPETITOR_DENSITY. Results are based on sample C, i.e. the sample for regression analyses $(n=90,5 \overline{2} 9)$.

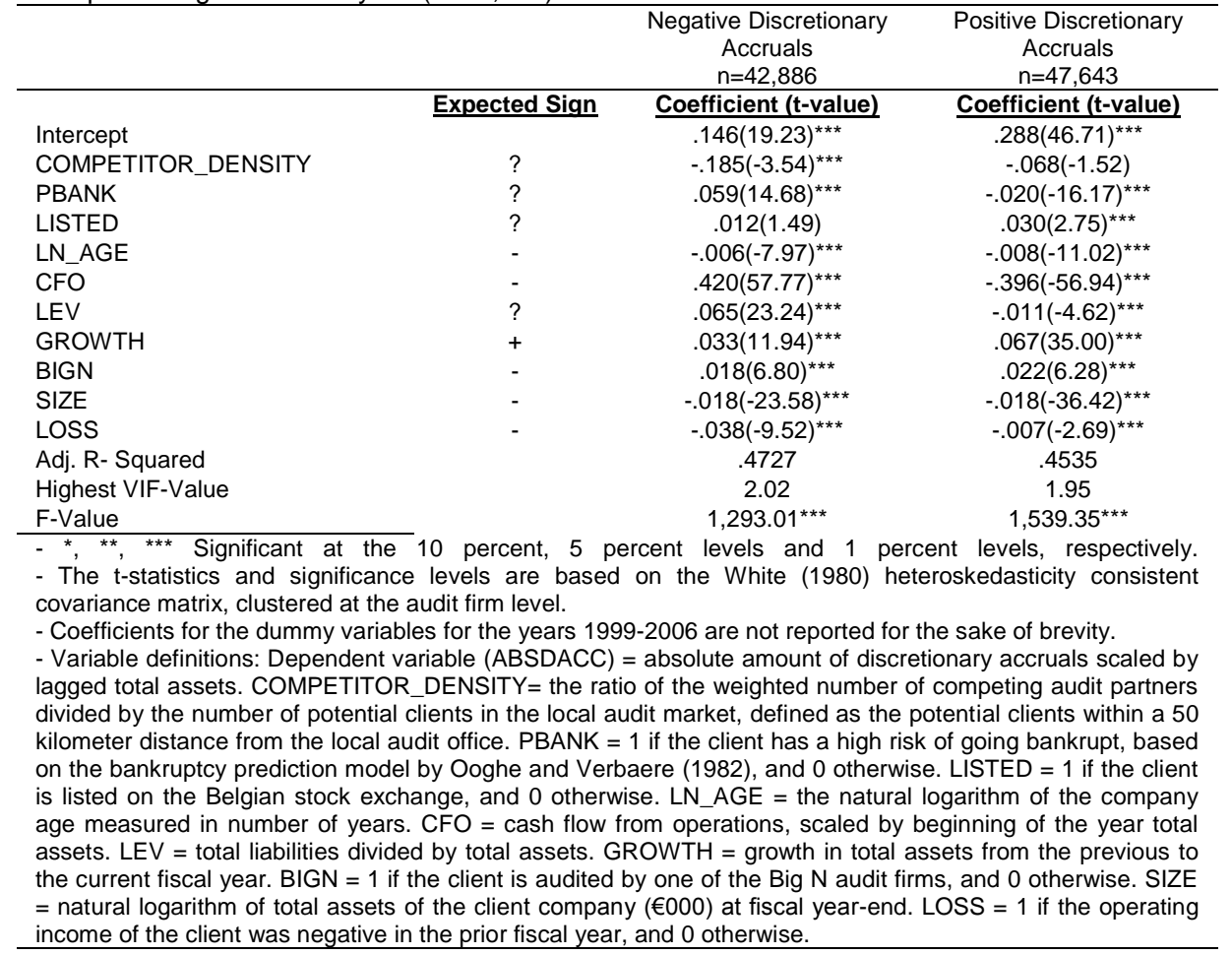

(Vander Bauwhede et al. 2003). The increased risk that downward earnings management is detected by the tax authorities may cause auditors to be stricter in preventing downward earnings management than upward earnings management.

To analyze whether audit quality differs with respect to upward and downward earnings management, the regressions for model (4.5) and (4.7) are examined using two separate samples: a sample of clients that engage in downward earnings management $(n=42,886)$, and a sample of clients that engage in upward earnings management $(n=47,643)$.

Table 4.8 reports the outcomes for the regression with HERFINDAHL as the experimental variable. Table 4.9 reports the regression outcomes for the experimental variable COMPETITOR_DENSITY. ABSDACC is used as the dependent variable, even though the sample is divided based on the sign of the discretionary accruals. This is done for ease of interpretation, because larger positive discretionary accruals, as well as larger negative discretionary accruals, can be associated with greater earnings management and thus lower audit quality (Warfield et al. 1995).

Table 4.8 presents the results for the regressions that use the Herfindahl index as the experimental variable. The results show that the adjusted Rsquares for model (4.5), estimated for the income decreasing and the 
income increasing earning management samples, are high: 47.23 and 45.46 percent respectively. ${ }^{18}$ The model fits are good as indicated by the model Fvalues $(1,325.51$ and 1,597.41). The coefficients for HERFINDAHL are negative and significant for the negative discretionary accruals sample $(\beta=-$ $.527, p<.05)$ and the positive discretionary accruals sample $(\beta=-.536, p<.10)$. Hence, the results are consistent with those reported in Table 4.5. The effect of market concentration on audit quality is not influenced by the direction of client earning management. The results suggest that audit market concentration is positively associated with audit quality, regardless of whether clients engage in upward or downward earning management. Furthermore, it can be concluded that a high bankruptcy risk (PBANK) is positively associated with absolute discretionary accruals $(\beta=.060, p<.01)$ for clients that manage earnings downwards and negatively associated with absolute discretionary accruals $(\beta=-.019, p<0.01)$ for clients that engage in upward earnings management. This suggests that signed discretionary accruals are lower for companies that have an increased bankruptcy risk. The coefficient for LISTED is insignificant for the income decreasing earnings management sample $(\beta=.013, p>.10)$ and positive and significant $(\beta=.030, p<.01)$ for the income increasing earning management sample. This suggests that publicly traded companies are more likely to manage their earnings upwards in order to attract potential investors, as opposed to managing their income downwards to reduce their taxable income. CFO and LEV also have different coefficients for each of the two subsamples. Cash flows from operating activities are associated with larger negative discretionary accruals $(\beta=.421, p<.01)$ and smaller positive discretionary accruals $(-.396, p<.01)$ which is consistent with findings from prior literature (e.g. Frankel et al. 2002). Higher leverage is also associated with more negative discretionary accruals $(\beta=.065, p<.01)$ and smaller income increasing discretionary accruals $(\beta=-.011, p<.01)$. The effects of the remaining control variables are consistent with those reported in Table 4.5.

Table 4.9 shows the results of estimating model (4.7) separately for the income increasing and income decreasing earning management subsamples. The adjusted R-squares are high, 47.27 and 45.35 percent respectively. The fit of both models is good as indicated by the model $\mathrm{F}$ values $(1,293.01$ and $1,597.35)$. COMPETITOR_DENSITY has a negative and significant coefficient $(\beta=-.185, p<.01)$ for the negative discretionary accruals subsample, suggesting that increased competition improves audit quality for clients that manage their earnings downwards. The level of competition as measured by COMPETITOR_DENSITY is, however, not associated with the degree of client upward earnings management $(\beta=-.068$, $p>$.10). A possible explanation relates to the fact that downward earnings management is scrutinized by the tax authorities (Vander Bauwhede et al. 2003), which may create incentives for auditors to constrain downward earnings management by clients (Van Tendeloo and Vanstraelen 2008). Auditors therefore have greater incentives to reduce downward earnings management than upward earnings management. The finding that competition only seems to have a positive impact on audit quality when there is public oversight present underlines the importance of public oversight. The 
effects of the control variables are consistent with those reported in Table $4.8 .^{19}$

4.4.3.2 Abnormal working capital accruals as a proxy for audit quality

Even though the modified Jones model is commonly used to estimate client earnings management, it is not without criticism. Becker et al. (1998) argue that managers have greater discretion with respect to working capital accruals than total accruals. Furthermore, Young (1999) shows that discretionary accruals derived from the modified Jones may contain systematic errors when normal accruals are estimated including depreciation. Therefore, as a robustness check, abnormal working capital accruals are used to proxy for audit quality, instead of discretionary accruals.

This robustness check uses the proxy for abnormal working capital accruals (AWCA) as developed by Defond and Park (2001). Abnormal working capital accruals are estimated as the difference between current year non-cash working capital and the non-cash working capital that could be expected based on last year's non-cash working capital and the increase in sales revenues from last year to the current year, as reflected in model (4.8). Consistent with Myers et al. (2003), all variables are scaled by average total assetss. AWCA is measured as follows:

$$
A W C A_{t}=W C_{t}-\left[\left(W C_{t-1} / S_{t-1}\right) \times S_{t}\right]
$$

where:

\begin{tabular}{|c|c|}
\hline $\mathrm{AWCA}_{t}$ & $\begin{array}{l}=\quad \text { abnormal work capital accruals in year } t \\
=\quad \text { year, } t-1 \text { refers to the prior year; }\end{array}$ \\
\hline$W C_{t}$ & $\begin{array}{l}\text { non-cash working capital in the current year computed as } \\
\text { (current assets - cash and short term investments) - (current } \\
\text { liabilities - short-term debt); }\end{array}$ \\
\hline & $\begin{array}{l}\text { non-cash working capital in the prior year; } \\
\text { revenues in current year; and } \\
\text { revenues in prior year. }\end{array}$ \\
\hline
\end{tabular}

The effects of the experimental variables on audit quality are tested again, now using absolute abnormal working capital accruals as a proxy for audit quality. The following three models are used to examine the effects of audit market concentration and competition on audit quality:

$$
\begin{aligned}
& \text { ABSAWCA }=\beta_{0}+\beta_{1} \text { HERFINDAHL }+\beta_{2} \text { PBANK }+\beta_{3} \text { LISTED }+ \\
& \beta_{4} \text { LN_AGE }+\beta_{5} \text { CFO }+\beta_{6} \text { LEV }+\beta_{7} \text { GROWTH }+\beta_{8} \text { BIGN }+ \\
& \beta_{9} \text { SIZE }+\beta_{10} \text { LOSS }+\sum_{11}^{18} \beta_{i} \text { YEAR_DUMMIES }+\epsilon . \\
& \Delta \text { ABSAWCA }=\beta_{0}+\beta_{1}|\Delta \mathrm{MS}|+\beta_{2} \Delta \text { PBANK }+\beta_{3} \Delta \text { CFO }+ \\
& \beta_{4} \Delta \text { LEV }+\beta_{5} \Delta \text { GROWTH }+\beta_{6} \Delta \mathrm{BIGN}+\beta_{7} \Delta \text { SIZE }+\beta_{8} \Delta \text { LOSS }+ \\
& \sum_{9}^{15} \beta_{i} \text { YEAR_DUMMIES }+\epsilon .
\end{aligned}
$$

$$
\begin{aligned}
& \text { ABSAWCA }=\beta_{0}+\beta_{1} \text { COMPETITOR_DENSITY }+\beta_{2} \text { PBANK }+ \\
& \beta_{3} \text { LISTED }+\beta_{4} \text { LN_AGE }+\beta_{5} \text { CFO }+\beta_{6} \text { LEV }+\beta_{7} \text { GROWTH }+ \\
& \beta_{8} \text { BIGN }+\beta_{9} \text { SIZE }+\beta_{10} \text { LOSS }+\sum_{11}^{18} \beta_{i} \text { YEAR_DUMMIES }+\epsilon .
\end{aligned}
$$


where:

ABSAWCA

$=$ the absolute amount of abnormal working capital accruals, scaled by average total assets; and

$\triangle$ ABSAWCA

$=$ the change in the absolute amount of abnormal working capital accruals, scaled by average total assets, from the previous to the current fiscal year audit office.

The remaining variables are defined as earlier.

The results of estimating models (4.9), (4.10), and (4.11), which rely on absolute abnormal working capital accruals as a proxy for audit quality, are shown in Table 4.10. Panel A of Table 4.10 shows results largely consistent with those reported in Table 4.5. The coefficient of HERFINDAHL remains negative and significant $(\beta=-.941, p<.01)$. The coefficient for CFO, however, is negative and significant for $(\beta=-.034, p<.01)$. This suggests that absolute abnormal working capital accruals are lower for companies that have higher operating cash flows. The directions and significance levels of the other control variables are consistent with those reported in Table 4.5. Hence, the results are generally robust to using abnormal working capital accruals as a proxy for audit quality.

The results of regressing the change in abnormal working capital accruals on absolute changes in market shares are shown in Panel B of Table 4.10. The coefficient of $\left|\Delta M S \_F I R M\right|$ is negative and insignificant $(\beta=-.077, p>.10)$, as are the coefficients for $\left|\triangle M S \_O F F I C E\right|(\beta=-.062, \quad p>.10)$ and $\mid \triangle M S$ PARTNER| $(\beta=-1.315, p>.10)$. Hence, the results do not show a significant association between market share changes and the provided audit quality. The adjusted R-squares of the model are also lower than those reported in Table 4.6 for the regressions where audit quality is proxied by absolute discretionary accruals. The relationship between changes in audit firm market share and audit quality is not robust to the use of this alternative proxy of audit quality.

The results of model (4.11), which examines the effect of COMPETITOR_DENSITY on ABSAWCA, are shown in Panel C of Table 4.10. This panel shows a negative and significant coefficient for COMPETITOR_DENSITY $(\beta=-.308, p<.01)$, which is consistent with the results reported in Table 4.7. Consistent with the results reported in Panel $A$ of Table 4.10 for the regression model based on HERFINDAHL, Panel C of Table 4.10 shows that the coefficient for CFO is negative and significant for $(\beta=-.034, p<.01)$. The results of the other control variables are consistent with those reported in Table 4.7.

\subsubsection{Discretionary accruals weighted by the standard deviation of cash flows from operating activities}

Hribar and Collins (2002) argue that the balance sheet approach to estimating accruals can result in misstated accruals. To overcome this problem, Hribar and Nichols (2007) suggest using a weighted least squares 
Table 4.10 - Panel A: Cross-sectional regression model for absolute working capital accruals.

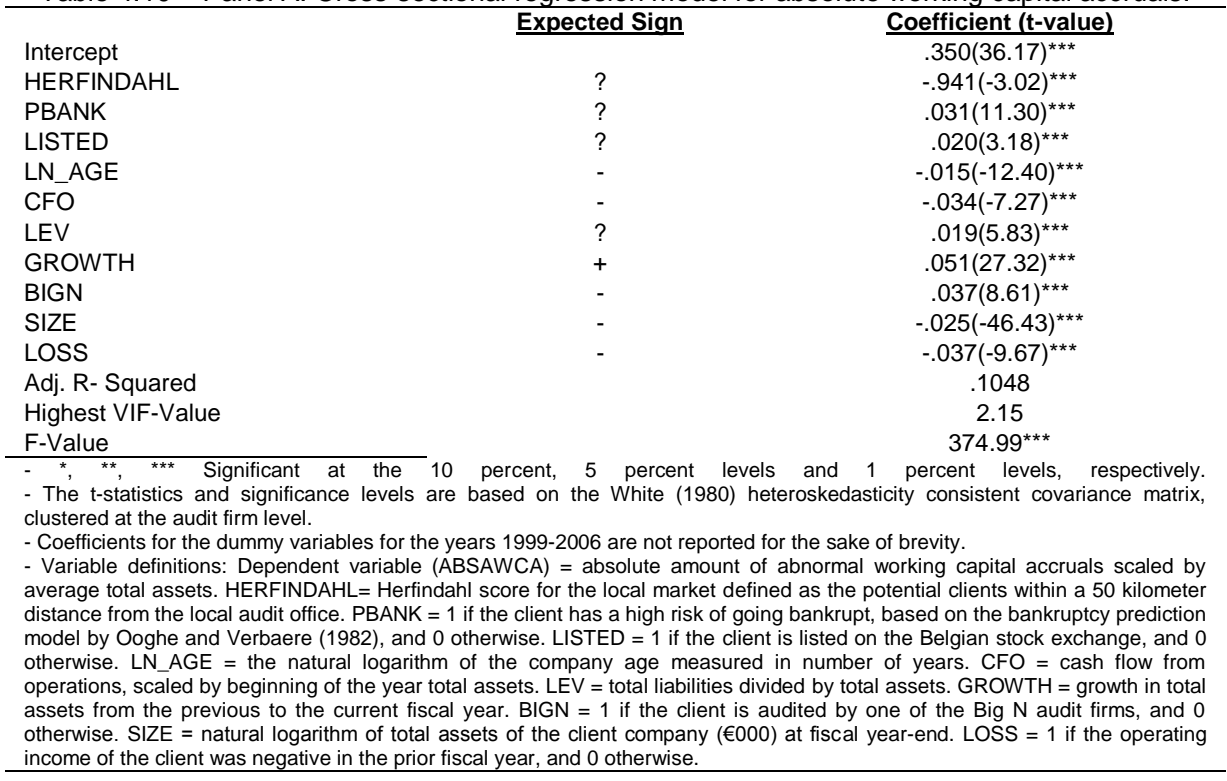

regression model to estimate discretionary accruals. For this study, it involves scaling the variables of model (4.1) again by cash flow volatility. Cash flow volatility is computed based on operating cash flows scaled by total assets over the prior 5 years.

Estimating model (4.1) using weighted least squares gives an estimation of discretionary accruals (DACC_WLS). The interpretation of this estimate of discretionary accruals is different from the usual interpretation, because it should be interpreted as the discretionary accruals scaled by the volatility of operating cash flows, as opposed to discretionary accruals scaled by total assets. To examine the effect of audit market concentration and competition on audit quality, proxied by the absolute value of absolute discretionary accruals estimated using the method suggested by Hribar and Nichols (2007), the following three models are tested:

$$
\begin{aligned}
& \text { ABSDACC_WLS }=\beta_{0}+\beta_{1} \text { HERFINDAHL }+\beta_{2} \text { PBANK }+ \\
& \beta_{3} \text { LISTED }+\beta_{4} \text { LN_AGE }+\beta_{5} \text { CFO }+\beta_{6} \text { LEV }+\beta_{7} \text { GROWTH }+ \\
& \beta_{8} \text { BIGN }+\beta_{9} \text { SIZE }+\beta_{10} \text { LOSS }+\sum_{11}^{13} \beta_{i} \text { YEAR_DUMMIES }+\epsilon .
\end{aligned}
$$

$\triangle \mathrm{ABSDACC}$ WLS $=\beta_{0}+\beta_{1}|\Delta \mathrm{MS}|+\beta_{2} \Delta \mathrm{PBANK}+\beta_{3} \Delta \mathrm{CFO}+$ $\beta_{4} \Delta \mathrm{LEV}+\beta_{5} \Delta \mathrm{GROWTH}+\beta_{6} \Delta \mathrm{BIGN}+\beta_{7} \Delta \mathrm{SIZE}+\beta_{8} \Delta \mathrm{LOSS}+$ $\sum_{9}^{10} \beta_{i} Y E A R \_D U M M I E S+\epsilon$.

$$
\begin{aligned}
& \text { ABSDACC_WLS }=\beta_{0}+\beta_{1} \text { COMPETITOR_DENSITY }+\beta_{2} \text { PBANK }+ \\
& \beta_{3} \text { LISTED }+\beta_{4} \text { LN_AGE }+\beta_{5} \text { CFO }+\beta_{6} \text { LEV }+\beta_{7} \text { GROWTH }+ \\
& \beta_{8} \text { BIGN }+\beta_{9} \text { SIZE }+\beta_{10} \text { LOSS }+\sum_{11}^{13} \beta_{i} \text { YEAR_DUMMIES }+\epsilon .
\end{aligned}
$$


Table 4.10 - Panel B: Cross-sectional regression model for the change in absolute abnormal

\begin{tabular}{|c|c|c|c|c|}
\hline & $\begin{array}{l}\text { Exp. } \\
\text { Sign }\end{array}$ & $\begin{array}{l}\text { (1) Audit Firm } \\
\text { Coefficient } \\
\text { (t-value) }\end{array}$ & $\begin{array}{l}\text { (2) Local Office } \\
\text { Coefficient } \\
\text { (t-value) }\end{array}$ & $\begin{array}{l}\text { (3) Audit Partner } \\
\text { Coefficient } \\
\text { (t-value) }\end{array}$ \\
\hline Intercept & & $.003(1.30)$ & $.003(1.22)$ & $.003(1.66)^{*}$ \\
\hline$\left|\Delta \mathrm{MS} \_F I R M\right|$ & $?$ & $-.077(-1.34)$ & & \\
\hline 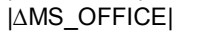 & $?$ & & $-.062(-.38)$ & \\
\hline | $\triangle \mathrm{MS}$ _PARTNER| & $?$ & & & $-1.315(-.75)$ \\
\hline$\triangle \mathrm{PBANK}$ & $?$ & $-.009(-3.32)^{\star * *}$ & $-.009(-3.31)^{\star * *}$ & $-.009(-3.32)^{\star \star *}$ \\
\hline$\triangle \mathrm{CFO}$ & - & $-.047(-10.34)^{\star \star *}$ & $-.047(-10.34)^{* * *}$ & $-.047(-10.34)^{\star \star \star}$ \\
\hline$\Delta \mathrm{LEV}$ & $?$ & $.055(4.87)^{\star * \star}$ & $.055(4.88)^{\star \star *}$ & $.055(4.88)^{* * *}$ \\
\hline$\triangle$ GROWTH & + & $.063(20.46)^{\star \star *}$ & $.063(20.48)^{\star * *}$ & $.063(20.48)^{\star \star \star}$ \\
\hline$\Delta \mathrm{BIGN}$ & - & $.004(1.25)$ & $.004(1.18)$ & $.004(1.24)$ \\
\hline$\Delta$ SIZE & - & $-.054(-15.54)^{\star \star \star}$ & $-.054(-15.56)^{\star * *}$ & $-.054(-15.55)^{\star \star \star}$ \\
\hline$\Delta$ LOSS & - & $.000(.05)$ & $.000(.05)$ & $.000(.04)$ \\
\hline Adj. R-Squared & & .0210 & .0210 & .0210 \\
\hline Highest VIF-Value & & 1.97 & 1.97 & 1.97 \\
\hline F-Value & & $66.38^{* * *}$ & $70.74^{\star * *}$ & $71.12^{\star \star \star}$ \\
\hline \multicolumn{5}{|c|}{ 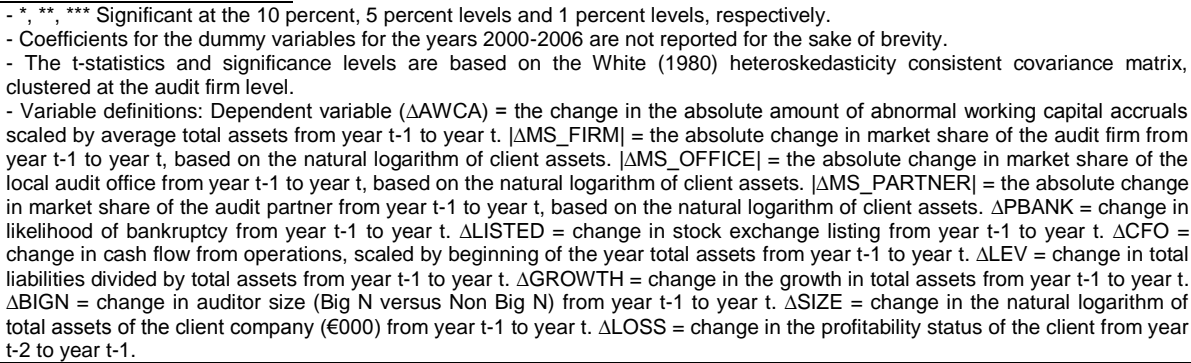 } \\
\hline
\end{tabular}

Table 4.10 - Panel C: Cross-sectional regression model for absolute working capital accruals. The experimental variable is COMPETITOR_DENSITY. Results are based on sample C, i.e. the sample for regression analyses $(n=90,539)$.

\begin{tabular}{|c|c|c|}
\hline & Expected Sign & Coefficient (t-value) \\
\hline Intercept & & $.355(51.86)^{\star \star \star}$ \\
\hline COMPETITOR_DENSITY & $?$ & $-.308(-5.07)^{\star \star \star}$ \\
\hline PBANK & ? & $.031(11.15)^{\star \star \star}$ \\
\hline LISTED & $?$ & $.019(3.02)^{\star \star \star}$ \\
\hline LN_AGE & - & $-.015(-12.14)^{\star \star *}$ \\
\hline CFO & - & $-.034(-7.19)^{\star \star *}$ \\
\hline LEV & ? & $.019(5.97)^{\star \star \star}$ \\
\hline GROWTH & + & $.051(27.67)^{\star * *}$ \\
\hline BIGN & - & $.033(6.99)^{\star \star \star}$ \\
\hline SIZE & - & $-.025(-47.95)^{\star \star \star}$ \\
\hline LOSS & - & $-.036(-9.42)^{\star * *}$ \\
\hline Adj. R-Squared & & .1055 \\
\hline Highest VIF-Value & & 1.97 \\
\hline F-Value & & $383.40^{\star \star *}$ \\
\hline \multicolumn{3}{|c|}{ 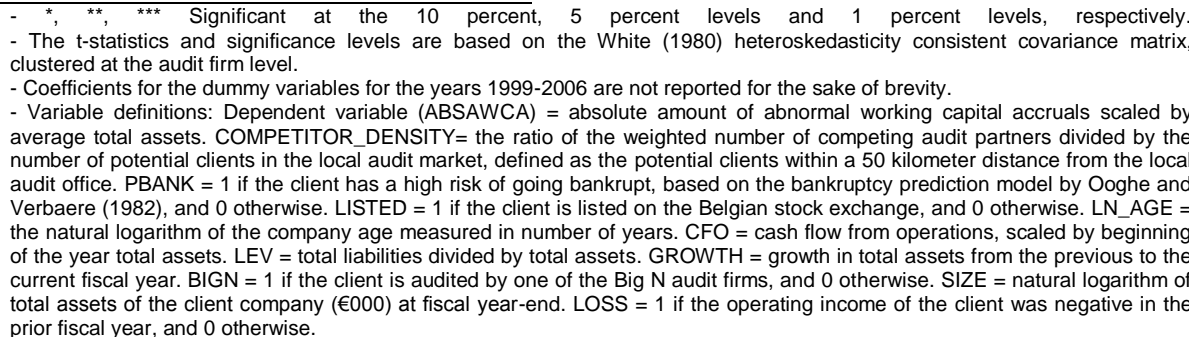 } \\
\hline
\end{tabular}


Table 4.11 - Panel A: Cross-sectional regression model for the absolute discretionary accruals estimated according to the weighted least squares method suggested by Hribar and Nichols (2007). The experimental variable is HERFINDAHL, $n=24,436$.

Intercept
HERFINDAHL
PBANK
LISTED
LN_AGE
CFO

where:

ABSDACC WLS = the absolute amount of discretionary accruals scaled by lagged total assets weighted by the standard deviation of cash flows from operations; and

$\triangle$ ABSDACC_WLS $\quad=\quad$ the change in absolute amount of discretionary accruals scaled by lagged total assets weighted by the standard deviation of cash flows from operations from year $t-1$ to year $t$.

The remaining variables are defined as earlier.

These regressions are tested using smaller sample sizes, because of the required availability of financial data for the prior five years in order to compute the standard deviations. Models (4.12) and (4.14) are therefore tested using a sample of 24,436 observations. Model (4.13) is tested using a sample of 15,013 observations.

The results of estimating these models are shown in Table 4.11. Panel A of Table 4.11 reports the results for model (4.12). The adjusted R-square for this model is 9.86 percent. The coefficient of HERFINDAHL remains negative and significant $(\beta=-.791, p<.05)$, suggesting that audit quality is higher in more concentrated audit markets. The effects of the control variables remain consistent with those reported in Table 4.5, with the exception of the effect of LISTED and CFO. The coefficient of LISTED is no longer significant $(\beta=.021, p>.10)$, indicating that there is no difference in audit quality between publicly traded and privately held companies. The coefficient for CFO is positive and significant $(\beta=.015, p<.05)$. These 
Table 4.11 - Panel B: Cross-sectional regression model for the absolute discretionary accruals estimated according to the weighted least squares method suggested by Hribar and Nichols (2007). The experimental variables are the change in market share measured at the audit firm level, the local audit office level and the audit partner level, $n=15,011$.

$\begin{array}{lll}\text { (1) Audit Firm } & \text { (2) Local Office } & \text { (3) Audit Partner }\end{array}$

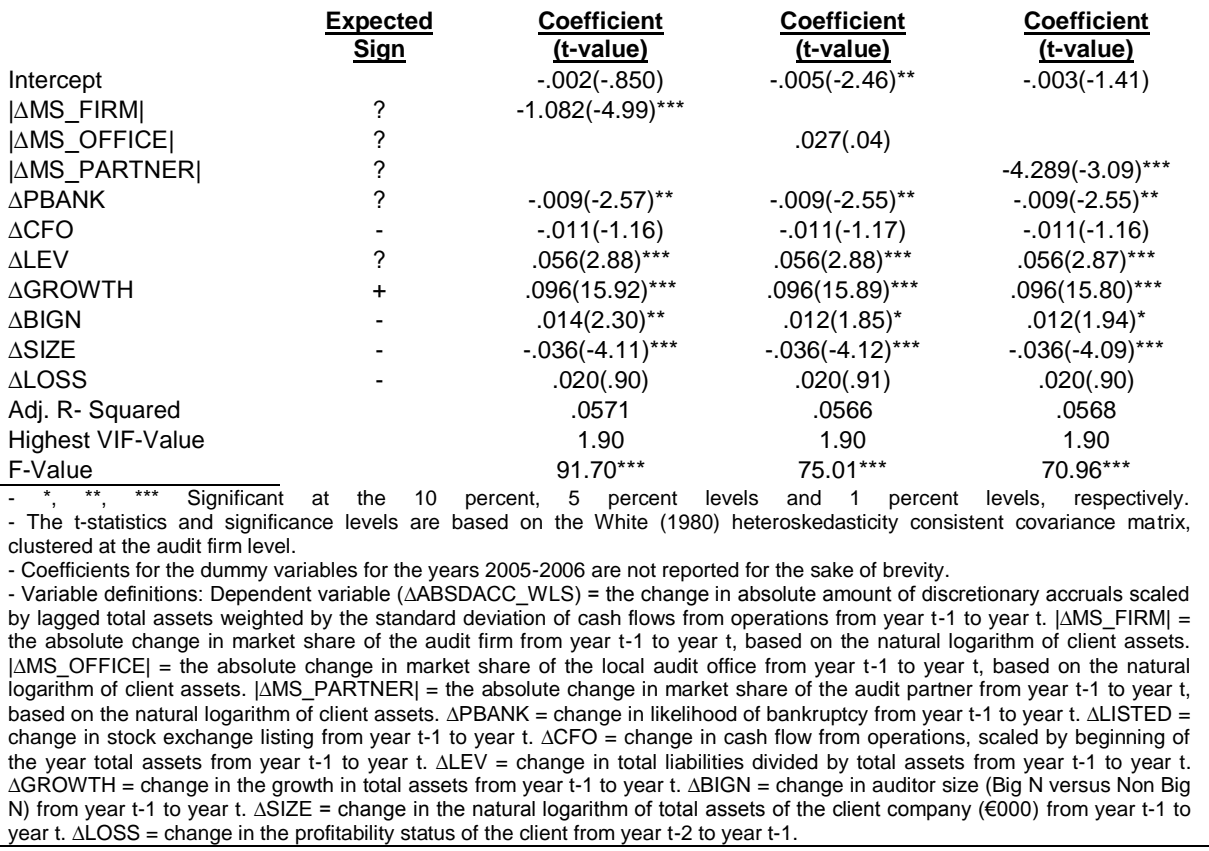

analyses show that the results are largely robust to using the discretionary accruals estimation method suggested by Hribar and Nichols (2007) to proxy for audit quality.

Panel B of Table 4.11 provides the results of estimating model (4.13), in which the change in discretionary accruals scaled by the volatility of operating cash flows is regressed on the absolute changes in auditor market shares. The coefficient of $\left|\Delta M S \_F I R M\right|$ remains negative and significant $(\beta=-$ $1.082, p<.01)$, while the coefficient of $\mid \triangle M S$ OFFICE $\mid$ remains insignificant $(\beta=.027, p>.10)$. The coefficient of $\left|\Delta M S \_P A \bar{R} T N E R\right|$ becomes negative and significant $(\beta=-4.289, p<.01)$. Hence, the results suggest that competition at the audit firm and audit partner level is positively associated with audit quality. The effect of $\triangle C F O$ is no longer significant. A significant positive coefficient is found for $\triangle \mathrm{BIGN}$, suggesting that switches to Big $N$ (non-Big N) audit firms are associated with increases (decreases) in client earnings management.

Panel $C$ of Table 4.11 shows the results for the estimation of model (4.14). The adjusted R-square for the model equals 9.89 percent. The coefficient of COMPETITOR_DENSITY remains negative and significant $(\beta=-.176, p<.05)$, suggesting that competition is positively associated with audit quality. The effects of the control variables are consistent with those reported in Panel A of Table 4.11. 
Table 4.11 - Panel C: Cross-sectional regression model for the absolute discretionary accruals estimated according to the weighted least squares method suggested by Hribar and Nichols (2007). The experimental variables is COMPETITOR_DENSITY, $n=24,436$.

\begin{tabular}{|c|c|c|}
\hline & Expected Sign & Coefficient (t-value) \\
\hline Intercept & & $.280(30.26)^{\star \star \star}$ \\
\hline COMPETITOR_DENSITY & $?$ & $-.176(-2.50)^{\star \star}$ \\
\hline PBANK $\quad-$ & $?$ & $.013(4.95)^{\star \star \star}$ \\
\hline LISTED & ? & $.022(1.09)$ \\
\hline LN_AGE & - & $-.008(-7.75)^{\star * *}$ \\
\hline CF- & - & $.015(2.48)^{\star *}$ \\
\hline LEV & $?$ & $.019(5.17)^{\star \star \star}$ \\
\hline GROWTH & + & $.070(26.45)^{\star * *}$ \\
\hline BIGN & - & $.022(5.42)^{\star \star \star}$ \\
\hline SIZE & - & $-.018(-32.38)^{* * *}$ \\
\hline LOSS & - & $-.014(-2.55)^{\star *}$ \\
\hline Adj. R- Squared & & .0989 \\
\hline Highest VIF-Value & & 1.22 \\
\hline F-Value & & $283.36^{\star * *}$ \\
\hline $\begin{array}{l}-{ }^{*},{ }^{* *},{ }^{* *} \text { Significant at the } 10 \text { percen } \\
- \text { The } t-\text { statistics and significance levels are based } \\
\text { clustered at the audit firm level. } \\
\text { - Coefficients for the dummy variables for the years } 2004 \\
\text { - Variable definitions: Dependent variable (ABSDACC_ } \\
\text { assets weighted by the standard deviation of cash flows } \\
\text { number of competing audit partners divided by the numb } \\
\text { clients within a } 50 \text { kilometer distance from the local audi } \\
\text { on the bankruptcy prediction model by Ooghe and Vert } \\
\text { Belgian stock exchange, and } 0 \text { otherwise. LN_AGE }=\text { th } \\
\text { CFO = cash flow from operations, scaled by beginning } \\
\text { GROWTH = growth in total assets from the previous to } t \\
N \text { audit firms, and } 0 \text { otherwise. SIZE }=\text { natural logarithm } \\
1 \text { if the operating income of the client was negative in the }\end{array}$ & $\begin{array}{l}\text { it, percent levels } \\
\text { on the White (1980) heter } \\
\text { 4-2006 are not reported for } \\
\text { VLS) = absolute amount of } \\
\text { S from operations. COMPE } \\
\text { ber of potential clients in th } \\
\text { t office. PBANK }=1 \text { if the cl } \\
\text { baere (1982), and } 0 \text { otherw } \\
\text { he natural logarithm of the } \\
\text { of the year total assets. } \\
\text { the current fiscal year. BIG } \\
\text { of total assets of the client } \\
\text { prior fiscal year, and } 0 \text { oth }\end{array}$ & $\begin{array}{l}\text { percent levels, respectively. } \\
\text { ty consistent covariance matrix, } \\
\text { brevity. } \\
\text { y accruals scaled by lagged total } \\
\text { NSITY = the ratio of the weighted } \\
t \text { market, defined as the potential } \\
\text { igh risk of going bankrupt, based } \\
=1 \text { if the client is listed on the } \\
\text { ge measured in number of years. } \\
\text { liabilities divided by total assets. } \\
\text { client is audited by one of the Big } \\
\in 000 \text { ) at fiscal year-end. LOSS }\end{array}$ \\
\hline
\end{tabular}

In conclusion, the above results appear largely robust to using different estimation methods of client earnings management. Hence, based on the results presented in this study it can be concluded that competition in the market for audit services is positively associated with audit quality. Therefore, there appears to be sufficient evidence to support the hypothesis that there is an association between competition and audit quality.

\subsection{Conclusion \& limitations}

\subsubsection{Conclusions}

High concentration ratios on the market for audit services have been central to criticism on the auditing industry. More concentrated markets are commonly argued to be less competitive, because supplier collusion is more likely to occur when there are only a few dominant firms. From a theoretical perspective the effect of competition on audit quality is not clear. Standard economic theory on product markets generally argues that competition will result in improved quality (e.g. Spence 1975; Leland 1977; Mussa and Rosen 1978). Increased competition, however, may negatively affect both components of audit quality. Auditor competence may be harmed if competition eliminates the price premium that is needed to induce auditors to pro- 
vide high quality audits (e.g. Hermanson et al. 1987; Kranton 2003). Auditor independence may be harmed if reduced audit fees force auditors to offset low initial revenues or early losses with quasi rents to be charged for future audits (DeAngelo 1981a).

This study uses data on the Belgian audit market to examine the relationship between competition and audit quality at three levels of analysis: the audit firm level, the local audit office level, and the audit partner level. Data availability in this setting facilitates the construction of client portfolios required to measure competition at these three levels of analysis. Spatial analysis, based on geographical coordinates of all local audit offices and all audited companies in Belgium, is used to measure local competition.

Regression analyses are used to examine the effect of competition on audit quality. The proxy for audit quality, absolute discretionary accruals, is regressed on three different experimental variables. The first experimental variable is the Herfindahl index, which is a measure of market concentration. The second experimental variable is market share mobility. To more precisely measure local competition, this study introduces a new measure of local competition: competitor density. This measure takes the geographical dispersion of auditors and clients within local markets into account, recognizing that different clients within a local market face different competing auditors, due to their geographical locations. Competitor density thus is the third experimental variable used in this study.

The results show a negative association between the Herfindahl index and absolute discretionary accruals, suggesting that audit quality is higher in more concentrated audit markets. A positive association between competition and audit quality is found when competition is measured by audit firm market share mobility. However, no association is found when market share mobility is measured at the local office level and the audit partner level. The lack of evidence at these lower levels of analysis is most likely due to the relative small changes in market share at the levels. The results furthermore show that competitor density is negatively associated with absolute discretionary accruals, again suggesting that there is a positive association between competition and audit quality.

In conclusion, the results based on competitor density and firm market share mobility show that there is a positive association between competition and audit quality. Furthermore, the results provide evidence that high market concentration does not equal low competition. In fact, audit quality appears to be higher in more concentrated audit markets. Concerns that high market concentration results in reduced audit quality are therefore not warranted. Hence, it is important for regulators to not focus on lowering market concentration. Instead, they should focus on ensuring that the market for audit services remains competitive, since both competition and market concentration are positively associated with audit quality.

\subsubsection{Limitations and recommendations for future research}

This study is not without limitations. First of all, measures of competition are computed based on client asset data as opposed to audit fee data, which are 
not publicly available in the setting of this study. Although prior research has shown a strong correlation between client assets and audit fees, it might be worth replicating this study in a setting where audit fee data are available.

Second, local markets in this study are defined based on the geographical locations of client and audit partners and the use of an arguably arbitrary cut-off. Although further analysis showed that the results are robust to variation in the distance used to define local markets, it is worthwhile for future studies to examine the effect of local competition on audit quality in differently defined local audit markets.

The final limitation relates to the measure of local competition, COMPETITOR_DENSITY, introduced in this paper. This measure is computed based on the number of audit partners that can potentially compete in a local audit market. Because the measure is constructed at the audit partner level, it implicitly assumes that audit partners working for the same firm compete against each other for clients. In reality, the extent of competition between audit partners that work for the same firm is limited. Although further analysis based on a measure of competitor density constructed at the local office shows that the level of analysis did not affect the results, future research could benefit from developing a measure of local competitor density that controls for local office capacity, while recognizing the constraints on competition between audit partners that work for the same audit firm and within the same local office. 


\section{Notes}

${ }^{1}$ Barriers to entry and economies of scale in auditing, as opposed to a lack of competition, provide alternative explanations for the high concentration levels commonly observed on audit markets (Dopuch and Simunic 1980; Danos and Eichenseher 1982).

${ }^{2}$ The difference between market concentration and competition is discussed in section 3.3.1.

${ }^{3}$ The audit market is characterized by information asymmetry regarding the quality of the provided audit. More specifically, the auditor has a better insight in the audit quality than the buyer(s) of audit services (i.e. the shareholder / audit committee), even though the audit can be affected by the client's management decisions. The quality of audit services is not easily observable and can be argued to be either sufficient or not sufficient. Even if an audit was not of sufficient quality, it may take a long time before errors are observed, if observed at all. As Akerlof (1970) points out, information asymmetry can lead to market failure in which good quality is driven out of the market. Leland (1979) indicates the need for minimum quality standards in this case. Minimum quality standards can be useful in reducing the negative social effects of asymmetric information. Hence, minimum quality standards do not only have an effect on the level of competition on the audit market, but are also used to prevent audit quality from being reduced to an unacceptable level.

${ }^{4}$ The top and bottom 1 percent of the observations are defined as observations with extreme sales volatility. Removing these observations is consistent with Carey and Simnett (2006) who argue that the estimation of discretionary accruals is unreliable for companies with volatile sales, because the estimation of discretionary accruals relies on the change in sales.

${ }^{5}$ Kothari et al. (2005) demonstrate that controlling for firm performance using current year return on assets $(\mathrm{ROA})$ instead of lagged ROA results in a better performing accruals measure.

${ }^{6}$ If the Herfindahl index is computed at the audit firm level, there would only be variation in the measure across years, not within years. The Herfindahl index would be the same for all observations within the same year of analysis.

${ }^{7}$ Sensitivity analyses show that the results are robust to increasing the range used to compute local competition to 60 kilometers, as well as decreasing the range to 40 kilometers.

${ }^{8}$ Buijink et al. (1998) use the market share mobility measure to analyze the relative competitiveness of two different audit markets, i.e. the Dutch and German markets for audit services. The current study uses market share mobility to analyze competition faced by auditors within a single audit market.

${ }^{9}$ As a result, the measure at the audit partner level implicitly assumes that partners working for the same local audit office compete against each other. While audit partners that work for the same local office may compete against each other for new clients, it is unlikely that they compete against each other for clients that are already part of the local office's client portfolio. COMPETITOR_DENSITY computed at the audit partner level provides an upper bound for the level of competition, whereas COMPETITOR_DENSITY computed at the local office level therefore provides a lower bound for the level of competition. To validate the findings, the same regressions have been tested using the number of competing audit offices as opposed to audit partners. Results indicate that the findings are robust to analyzing competitor density at the local office level.

${ }^{10}$ This range is similar to the range used to define local audit markets for the Herfindahl index, as discussed in section 3.3.1. The results of the regressions based on competitor density are robust to changing the local competition range to either 40 or 60 kilometers.

${ }^{11}$ To incorporate that not every audit partner has the required experience and resources to audit every potential client, the number of competing audit partners is constrained based on the size 
of the client (measured as total assets) and the size of the currently largest client of the local audit office at which the audit partner is employed. To reflect the growth potential of local audit offices, an audit partner is regarded as a potential competitor if the client size does not exceed that of the audit office's largest client plus 10 percent. Sensitivity analyses show that the results are robust to variations in the growth restriction between 0 and 25 percent of the asset base of the local office's largest client.

${ }^{12}$ Division by the number of clients in a local market is required because competition is a function of both the number of audit partners and the number of audit clients.

${ }^{13}$ The Big N is defined as Arthur Andersen. Deloitte, Ernst \& Young, KPMG and PwC. Arthur Andersen ceased to exist after the Enron scandal, and is therefore only included in the first four years of the sample.

${ }^{14}$ Simunic (1980) argues the audit market is competitive only for small audit firms. Hence, the variable BIGN may pick up differences in competition. The variance inflation factors do not suggest that multicollinearity is an issue. Furthermore, the regression analyses are analyzed while excluding the variable BIGN to examine whether the results are affected by a possible correlation between the competition measures and the control variable BIGN. The exclusion of the control variable BIGN does not influence the direction or significance levels of the remaining explanatory variables. Hence, the results are not affected by a possible correlation between the experimental variable and the control variable BIGN. The control variable BIGN is therefore retained in the regression analyses.

${ }^{15}$ The bankruptcy prediction model by Ooghe and Verbaere (1982) is specifically developed for Belgian companies. It consists of the following ratios: accumulated profit (loss) and reserves/total liabilities; taxes and social security charges/short-term external liabilities; cash/restricted current assets; work in progress and finished goods/restricted current assets; short-term financial debts/short-term external liabilities. The optimal cut-off point of .1304 is used to distinguish companies with a high bankruptcy risk from clients with a low bankruptcy risk (Ooghe et al. 1995).

${ }^{16}$ Consistent with Leuz et al. (2003), cash flows from operations is computed as operating income minus total accruals.

${ }^{17}$ The reported results are robust to inclusion of two dummy variables that distinguish between three regional areas in Belgium: Flanders, Wallonia, and the country's capital city Brussels. Flanders is the Flemish-speaking part of Belgium. Wallonia is the French-speaking part of the country.

${ }^{18}$ The higher adjusted R-squares compared to the results reported in Table 5 can be explained by the significance of the control variable CFO. This control variable captures a large extent of the variation in the dependent variable (ABSDACC) when the sample is split based on the direction of client earnings management.

${ }^{19}$ The analysis of the effect of market share mobility on changes in audit quality uses the change in the absolute value of discretionary accruals as a proxy for audit quality, because companies can manage earnings either upwards or downwards. An analysis of changes in signed discretionary accruals would therefore not lead to meaningful results. For this reason, no robustness check is conducted for the effect of market share mobility on the change in signed discretionary accruals. 


\section{Chapter 5 \\ Summary and Discussion}

\subsection{Introduction}

This chapter first provides a summary of the findings of the three empirical studies included in this dissertation. Subsequently, the conclusions and implications are presented. This is followed by a discussion of potential limitations and suggestions for future research.

\subsection{Summary of the empirical studies}

This dissertation consists of three empirical studies on audit quality. Each of the three studies uses data from the Belgian market for audit services. Belgium is an appropriate setting for these studies because of its unique characteristics which enable the construction of complete client portfolios at the audit firm, the local office, and the audit partner level.

The first study, discussed in chapter 2, investigates whether audit firms use audit partner expertise as a risk management strategy. Audit firms are expected to allocate audit partners based on the expertise of the audit partners and the risk characteristics of the clients for two reasons. First of all, audit standards require the engagement partner to be assured that the audit engagement team has a sufficient amount of experience with clients of a similar nature (ISA 220.A11). The engagement partner is the leader of the audit team, and his experience can be expected to be an important aspect of the overall required experience level of the engagement team. Second, from a risk management perspective, audit firms are required to sufficiently manage client risks, since a single audit failure can have a significant impact on the profitability and reputation of an entire audit firm.

However, despite the benefits of using audit partner expertise as a risk management strategy, audit firms may fail to use it effectively for three reasons. First of all, the large variation in client characteristics and partner expertise levels makes the allocation of audit partners to clients a complex task (Dopuch et al. 2003). Second, more experienced audit partners may use their power within the audit firm to avoid being allocated to more risky clients because they may be held personally accountable in case of audit failure or litigation. Third, less experienced audit partners may be under pressure to expand their client portfolios due to career concerns. Hence, less experienced auditors may be willing to audit those clients that experienced audit partners are not interested in.

The study examines whether audit partner expertise is used as a risk management strategy for three commonly distinguished risk categories (Huss and Jacobs 1991): audit risk, client business risk, and auditor business risk. Furthermore, two components of auditor expertise are 
examined: general partner experience and industry experience. The results, based on an analysis of clients to which a new audit partner was allocated, show that general audit partner experience is used as a risk management strategy for auditor business risk. Furthermore, evidence shows that partner industry experience is used to manage audit risk. No evidence is found that audit firms allocate partners with greater expertise to clients with higher client business risk. Overall, the results discussed in chapter 2 suggest that audit firms use audit partner expertise to manage audit risk and auditor business risk, but not client business risk.

The second study, discussed in chapter 3 , examines the effect of auditorclient economic bonding on audit quality. Audit fees may contribute to an economic bond between the auditor and the client. A strong auditor-client economic bond may impair the independence of the auditor, resulting in lower audit quality. However, auditors also face litigation and reputation costs in case of an audit failure. These costs are positively associated with client size. Reputation and litigation costs may therefore induce auditors to remain independent from clients that provide high audit fees (Reynolds and Francis 2001).

The off-setting effect of reputation and litigation costs on auditor-client economic bonding may however be limited to the audit firm level, since the benefits of audit fees mainly accrue to the local audit office or audit partner, whereas litigation and reputation costs are shared by the audit firm. Hence, there may be a moral hazard problem in which audit partners make decisions to maximize their own utility as opposed to firm value. Furthermore, clients are more likely to contribute to a significant source of revenue for a local office or audit partner, than for an audit firm. Hence, it is more likely that auditor-client economic bonding impairs auditor independence at the local office level or audit partner level rather than at the audit firm level office (Reynolds and Francis 2001). The study therefore measures auditor-client economic bonding at three levels of analysis: the audit firm level, the local office level, and the audit partner level.

Furthermore, the study distinguishes between clients that engage in upward earnings management and clients that engage in downward earnings management. Tax authorities are more likely to scrutinize the financial statements of companies that manage earnings downwards than of companies that manage earnings upwards, since downward earnings management results in a reduction of taxable income. Fear that downward earnings management will be detected by the tax authorities may create incentives for auditors to be stricter in constraining downward earnings management than upward earnings management (Vander Bauwhede et al. 2003). Given the relatively low litigious environment in Belgium, these differences in regard to the extent of public oversight create a setting in which can be examined whether reputation concerns are sufficient mechanism to ensure that audit quality is not compromised for clients on which auditors are economically dependent. Furthermore, it enables testing whether public oversight enhances audit quality.

The results of the study show that high levels of auditor-client economic bonding increase the likelihood that auditors acquiesce to client pressure to 
allow earnings management. This finding is however restricted to clients that manage their earnings upwards. Auditors do not give in to pressure from clients on which they are economically dependent to allow downward earnings management. This could imply that auditors may fear downward earnings management to be detected by the tax authorities (Vander Bauwhede et al. 2003), suggesting that public oversight is an important factor in maintaining audit quality. Furthermore, the results do not support the notion that problems related to auditor-client economic bonding are more likely to manifest at the local office level and audit partner level than at the audit firm level. A possible explanation lies in the fact that Belgian audit firms and local offices are relatively smal. Independence issues at the audit partner level are therefore likely to also result in independence issues at the local office level and audit firm level, implying that any differences in results between the three levels will be limited.

The third empirical study, discussed in chapter 4, analyzes the association between competition on the market for audit services and audit quality. The market for audit services is commonly criticized to not be competitive because of the typically high market concentration levels (e.g. Government Accountability Office 2003; Financial Stability Forum 2006). A lack of competition is commonly argued to result in reduced audit quality (Yardley et al. 1992). However, it can be disputed whether high (static) concentration levels reflect a lack of competition (Buijink et al. 1998). Furthermore, while standard economic theory predicts a positive association between competition and quality on product markets, this prediction cannot be directly translated to the market for audit services because the audit industry is highly regulated and audit quality is not directly observable. Competition may result in reduced audit fees, which could reduce incentives for auditors to invest in quality, harming auditor competence and thereby lowering audit quality (Leland 1979; Kranton 2003). In addition, there may be a negative effect of competition on auditor independence, since lower audit fees may cause auditors to be dependent upon future audits of the same client to offset initial losses (DeAngelo 1981a). Reduced auditor competence and auditor independence will negatively affect audit quality (DeAngelo 1981a).

To test whether high concentration levels reflect limited competition, and to examine the association between competition on the market for audit services and audit quality, this study uses one measure of market concentration and two measures of competition. The Herfindahl index is used as a measure of market concentration. The first measure of competition is based on the market share mobility measure used by Buijink et al. (1998). The second measure of competition is a newly developed measure of competitor density, based on the geographical coordinates of all local audit offices and audit clients in Belgium.

The empirical results show that audit quality proxied by the magnitude of absolute discretionary accruals is higher in more concentrated audit markets. Overall, the results based on the competition measures show that audit quality is positively associated with competition. This finding suggests that 
high concentration levels do not necessarily reflect limited competition and that highly concentrated audit markets can still be competitive.

\subsection{Conclusions and implications}

The first study deals with the use of audit partner expertise as a risk management strategy. While audit firms are expected to benefit from allocating audit partners with the highest expertise to those clients that pose higher risks, the actual allocation might be too complex or may be hindered by audit partner incentives. The findings show that audit firms allocate audit partners with greater general experience to clients which pose a higher auditor business risk. Audit risk is managed by the allocation of partners with greater industry experience. However, no evidence is found that client business risk is managed using partner expertise. Even though it is possible that audit firms use alternative risk management strategies to manage this type of risk, auditors should examine whether client business risk is sufficiently managed as required by auditing standards (e.g. ISA 220.14; AU. 312.02). Furthermore, it is worthwhile to investigate why audit partner expertise is not used as a risk management strategy for client business risk. Possible reasons relate to risk aversion of experienced audit partners and career pressure faced by less experienced audit partners. Pressure to develop their client portfolio might create incentives for less experienced partners to attract clients regardless of their risk characteristics. Furthermore, it is important to note that the use of general partner experience as a risk management strategy is limited to auditor business risk. Although prior research has indicated that public listing status, a proxy for auditor business risk, is considered by auditors to reflect increased auditor business risk, auditors and regulators need to consider whether the allocation of experienced personnel to clients with a high auditor business risk is in fact the result of a risk management strategy. Alternatively, it could be explained by prestige and career perspectives associated with the audit of a listed client. This alternative explanation is a concern especially since the use of general audit partner experience as a risk management strategy is limited to auditor business risk. Hence, it is important for audit firms and regulators to consider whether audit partner experience is used by audit firms as a risk management strategy, and whether audit quality could benefit from ensuring that audit partners with more years of experience are allocated to clients with high audit risk and high client business risk. With respect to the current debate on fair value accounting and the need for audit partner expertise (e.g. IAASB 2008), the findings of this study suggest that auditors should consider what aspect of expertise (i.e. the number of years of experience or industry experience) is required for auditing judgments associated with fair value accounting. Furthermore, auditors and regulators need to ensure that guidelines and regulation are in place to ensure that the allocation of experts to engagements occurs in a manner in which audits can benefit most from audit partner expertise. 
The results of the second study, which analyzes the effect of auditorclient economic bonding on audit quality, suggest that high auditor-client economic bonding only induces auditors to acquiesce to client pressure to allow upward earnings management, not downward earnings management. This result can be explained by an increased fear by auditors that material misstatements will be detected by the tax authorities if clients engage in income decreasing, hence taxable income decreasing, earnings management. This result shows the importance of public oversight in maintaining audit quality, and adds to the current debate on the need for increased public oversight (e.g. Financial Stability Forum 2008; Basel Committee 2008). The results reported in the study are consistent across the three levels of analysis (i.e. the audit firm level, the local office level, and the audit partner level). This suggests that there is no moral hazard problem arising from the fact that reputation and litigation costs are carried by the entire firm, while the benefits related to the audits of single clients pertain mostly to individual audit partners and local audit offices. This may be due to the fact that audit firms in Belgium are relatively small. Conflicts of interests between individual audit partners and audit firms will be less prominent in smaller audit firms than in larger audit firms, because audit partners in small audit firms typically have a relatively larger interest in the audit firm.

The third and final study examines the relationship between competition on the market for audit services and audit quality. The results of this study show that competition is positively associated with audit quality. This finding is in line with the positive effect of competition on quality suggested by standard economic theory. It is therefore important for regulators to ensure that the market for audit services remains competitive. The results also show a positive relationship between audit market concentration and audit quality. This finding therefore shows that high market concentration does not, by definition, reflect limited competition. It is important for regulators to take this into account to make certain that regulation is not merely aimed at lowering concentration levels. Although this study shows mixed findings regarding the effect of audit firm size on audit quality, the positive association between concentration levels and audit quality suggests that audit quality may be higher in more concentrated audit markets. Robustness checks conducted for the study show that the positive association between competition on the audit market and audit quality is limited to clients that engage in downward earnings management. No effect between competition and audit quality is found for clients that engage in upward earnings management. This finding is likely related to fear by auditors that downward earnings management will be detected by the tax authorities. This may induce auditors to be stricter in reducing downward earnings management than upward earnings management. This underlines the importance of public oversight in maintaining audit quality.

Overall, the findings of this dissertation suggest that there are opportunities for the audit profession and audit regulators to enhance audit quality. With respect to the use of partner expertise as a risk management strategy, the results of the first study show that audit firms allocate audit partners with greater expertise to clients that have a higher audit risk and 
clients that have a higher auditor business risk. However, no association is found between client business risk and audit partner expertise. While one explanation could be that alternative risk management strategies are more efficient at managing this type of risk, it is also possible that auditor partner expertise is not used as a risk management strategy due to risk aversion by auditor partners. Therefore, audit firms and regulators should focus on ensuring that the partner allocation process is effective since it reduces the risk that client risks are not sufficiently managed. Furthermore, the allocation of partners with greater expertise to risky clients results in a higher probability that material misstatements are detected by the auditor. Hence, it is important that auditors with high levels of expertise are allocated to clients with greater risk because this will have a positive impact on audit quality. With respect to auditor independence, the findings of the second study suggest that auditors may acquiesce to pressure by influential clients to allow earnings management. Hence, regulators and audit firms should focus on ensuring that auditors remain independent from their clients. Furthermore, the findings suggest that public oversight is an important factor in maintaining auditor independence. This adds to the current debate on whether public oversight is needed to enhance audit quality. With respect to competition, the third study shows that competition has a positive association with audit quality, but only for clients that engage in income reducing earnings management. This suggests that regulators need to ensure that the market for audit services remains competitive, because competition is positively associated with audit quality. Furthermore, the findings of the third study underline the importance of public oversight in maintaining audit quality.

\subsection{Limitations and suggestions for future research}

There are a number of limitations to this dissertation. Some are general limitations that relate to all three studies, while some specifically relate to an individual study. The first general limitation relates to the fact that audit fee data were not publicly available in Belgium at the time of the study. This limitation affects each of the three studies. As a result of this limitation, the first study is required to measure industry experience based on the sales revenues and total assets of the audit clients instead of audit fees. The second study measures auditor-client economic bonding based on client revenues instead of audit fees. Similarly, the measures of competition used in the third study are computed based on client asset data instead of audit fee data. However, the natural logarithms of client revenues and client assets are found to be highly correlated with audit fees (e.g. Francis 1984, Moizer and Turley 1987, Craswell et al. 1995, Reynolds and Francis 2001). In addition, the Belgian Institute of Auditors requires a direct relationship between the level of the audit fees and client characteristics. Every auditor has to report an overview of its clients, the audit fees and the amount of hours to the Belgian Institute of Auditors, who verify the appropriateness of 
the audit fees. Therefore, the use of client revenues or client assets instead of audit fees does not seem to be a major concern. Although the proxies provide a reliable estimation of auditor-client economic bonding and relative market share distributions, they do not control for possible changes in the level of audit fees. Hence, it would be valuable to replicate these studies in a setting where regulators require both public and private companies to disclose audit fees.

The second general limitation relates to the external validity of the studies. Belgium has a relatively low litigious environment compared to commonly used settings in audit research, such as the U.K. and the U.S. Even though prior research has shown that there are mechanisms other than litigation in place to ensure that audit quality is maintained at a sufficiently high level regardless of a relative lack of litigation (Gaeremynck and Willekens 2003), external validity of the results may be considered an issue. The implication of this lack of litigation for the findings of the first study is that it is even more likely for audit partner expertise to be used as a risk management strategy in more litigious environments where the possible impact of unmanaged risks is greater. Regarding the second study, it is possible that auditors would constrain downward earnings management even further in a high litigious environment than in a low litigious environment. In contrast to the reported findings related to upward earnings management, however, it is possible that auditors will not acquiesce to pressure from their most influential clients to allow upward earnings management in a setting with a higher risk of litigation. Future research could benefit from separately examining the effect of litigation and public oversight on the likelihood that auditors acquiesce to client pressure to allow upward earnings management in more litigious environments. It is unclear whether the association between competition and audit quality would be different in a setting with relatively higher litigation risk (e.g. Chaney et al. 2003).

In addition to these general limitations, there are a number of limitations specific to individual studies. A specific limitation to the first study is the use of public data. Because the study is based on public data, it is not possible to control for all alternative risk management strategies that audit firms may use. To overcome this problem, the study uses a sample in which most of the other risk management strategies are unlikely to be used, and in which the use of partner expertise as a risk management strategy is most likely to occur. However, it would be worthwhile for future research to simultaneously examine the different risk management strategies that audit firms can use to manage client risk, as well as the extent to which audit firms use different risk management strategies based on different client risk characteristics.

The use of public data results in an additional limitation for the first study. The measures of risk used in this study are based on public data as opposed to private data, which may potentially provide more accurate estimations of client risk. Private data, however, might be biased by auditor judgments. The use of public data to measure client risk does therefore not necessarily result in a less reliable measure of risk than a measure of risk based on private data. 
A limitation related to the third study is that the local markets in this study are defined based on the geographical locations of client and audit partners and an arguably arbitrary cut-off. Although robustness checks show that the results variations in the cut-off distance do not affect the results in any significant way, it is still worthwhile for future research to study the association between competition and audit quality using differently defined local audit markets.

The final limitation, which also affects the third study, relates to the measure of local competition developed in this study. This measure is developed at the audit partner level. It therefore implicitly assumes that audit partners working for the same audit firm also compete for clients. Competition amongst partners that are employed at the same audit firm is however likely to be very limited. Although sensitivity tests suggest that this issue does not have a significant impact on the results, it would be valuable if future research could develop a measure of local competition which takes local office capacity in account, as well as the limited competition amongst audit partners that work for the same audit firm.

Finally, there is one additional suggestion for future research. Belgian audits are based on three year renewable contracts, referred to as mandates. Auditors might be more likely to acquiesce to client pressure to allow earnings management in the last year of the mandate than in the prior two years in the hope of renewing the contract for an additional three year. Hence, audit quality is possibly lower during the last year of the mandate than during the first two years of the mandate. However, no relationship between the year of the mandate and earnings quality was observed. Future research could analyze data on the subsequent fiscal year to examine whether more earnings management discretion was given to clients that subsequently switched to another audit firm, because the auditor might have been under pressure to allow client earnings management in order to increase the likelihood of mandate renewal. Because of data restrictions caused by the need to measure auditor tenure, the study did not analyze whether clients switching to another audit firm in the subsequent year showed increased earnings management behavior during the year prior to the switch. 


\section{References}

A

Aerts, K. (2002). Taken en Aansprakelijkheden van Commissarissen en Bedrijfsrevisoren. Brussels: Larcier.

Ahmed, A.S., Duellman, S., and Abdel-Meguid, A.M. (2006). The Sarbanes Oxley act, auditor independence and accounting accruals: an empirical analysis. Working paper, Texas A\&M University.

Akerlof, G.A. (1970). The market for "lemons": quality uncertainty and the market mechanism. Quarterly Journal of Economics, 84(3), 488-500.

American Institute of Certified Public Accountants (AICPA). 1978. Commission on Auditors' Responsibilities: Report, Conclusions and Recommendations. New York, NY: AICPA.

American Institute of Certified Public Accountants (2006). Audit Risk and Materiality in Conducting an Audit. Statement on Auditing Standards No. 47. New York, NY: AICPA.

Anthony, J.H., and Ramesh, K. (1992). Association between accounting performance measures and stock prices: a test of the life cycle hypothesis. Journal of Accounting and Economics, 15(2-3), 203-227.

Antle, R., Gordon, E., Narayanamoorthy, G. and Zhou, L. (2006). The joint determination of audit fees, non-audit fees, and abnormal accruals. Review of Quantitative Finance and Accounting, 27(3), 235-266.

Asare, S., Cohen, J., and Trompeter, G. (2005). The effect of non-audit services on client risk, acceptance and staffing decisions. Journal of Accounting and Public Policy, 24(6), 489-520.

Ashbaugh, H., LaFond, R., and Mayhew, B.W. (2003). Do nonaudit services compromise auditor independence? Further Evidence. The Accounting Review, 78(3), 611-639.

\section{B}

Ball, R., and Shivakumar, L. (2005). Earnings quality in UK private firms: comparative loss recognition timeliness. Journal of Accounting and Economics, 39(1), 83-128.

Bandyopadhyay, S. P., and Kao J.L. (2004). Market structure and audit fees: a local analysis. Contemporary Accounting Research, 21 (3), 529-561.

Banker, R.D., Khosla, I., and Sinha, K.K. (1998). Quality and competition. Management Science, 44(9), 1179-1192.

Beatty, A.L., Ke, B., and Petroni, K.R. (2002). Earnings management to avoid earnings declines across publicly and private held banks. The Accounting Review, 77(3), 547-570.

Becker, C. L., DeFond, M. L., Jiambalvo, J., and Subramanyam, K.R. (1998). The effect of audit quality on earnings management. Contemporary Accounting Research, 15(1), 4-24.

Bedard, J.C. (1989). An archival investigation of audit program planning. Auditing: A Journal of Practice \& Theory, 9(1), 57-71. 
Bedard, J.C., and Biggs, S.F. (1991). Pattern recognition, hypotheses generation, and auditor performance in an analytical task. The Accounting Review, 66(3), 622-642.

Bedard, J.C., and Johnstone, K.M. (2004). Earnings manipulation risk, corporate governance risk, and auditor's planning and pricing decisions. The Accounting Review, 79(2), 277-304.

Bell, T.B., Marrs, F.O., Solomon, I., and Thomas, H. (1997). Auditing organizations through a strategic systems lens. New Jersey: KPMG LLP.

Bell, T.B., Bedard, J.C., Johnstone, K.M., and Smith, E.F. (2002). KRisk: a computerized decision aid for client acceptance and continuance risk assessment. Auditing: A Journal of Practice \& Theory, 21(2), 97-113.

Beneish, M.D., and Press, E. (1995). Interrelation among events of default. Contemporary Accounting Research, 12(1), 57-84.

Biggs, S.F., Mock, T.J., and Watkins, P.R. (1988). Auditor's use of analytical review in audit program design. The Accounting Review, 63(1), 148-161.

BIS (2008), External audit quality and banking supervision. Basel: Bank for International Settlements (December).

Bonner, S.E., and Lewis, B.L. (1990). Determinants of auditor expertise. Journal of Accounting Research, 28(Supplement), 1-20.

Bradford, W.D., and Martin, R.E. (2000). Partnerships, profit sharing, and quality competition in the medical profession. Review of Industrial Organization, 17, 193-208.

Brown, L. D. (2001). A temporal analysis of earnings surprises: Profits versus losses. Journal of Accounting Research, 39, 221-241.

Buijink, W.F.J., Maijoor, S.J., and Meuwissen, R.H.G. (1998). Competition in auditing: evidence from entry, exit, and market share mobility in Germany versus The Netherlands. Contemporary Accounting Research, 15 (3), 385-404.

Burgstahler, D.C., Hail, L., and Leuz, C. (2006). The importance of reporting incentives: earnings management in European private and public firms. The Accounting Review, 81(5), 983-1016.

C

Caplan, D., and Raedy, K. (2005). Office size and audit quality. Working paper, University of North Carolina.

Carcello, J.V., and Nagy, A.L. (2004). Audit firm tenure and fraudulent financial reporting. Auditing: A Journal of Practice and Theory, 23(2), 5569.

Carcello, J.V., Vanstraelen, A., and Willenborg, M. (2010). Rules rather than discretion in audit standards: going-concern opinions in Belgium. The Accounting Review, 84(5), 1395-1428.

Carey, P., and Simnett, R. (2006). Audit partner tenure and audit quality. The Accounting Review, 81(3), 653-676.

Carlton, D. W., and J. M. Perloff (1994). Modern industrial organization. Second edition. New York: Harper Collins. 
Chaney, P.K., Jeter, D.C., and Shaw, P.E. (2003). The impact on the market for audit services of aggressive competition by auditors. Journal of Accounting and Public Policy, 22(6), 487-516.

Chaney, P.K., Jeter, D.C., and Shivakumar, L. (2004). Self-selection of auditors and audit pricing in private firms. The Accounting Review, 79(1), 51-72.

Chen, S., Sun, S.Y.J., and Wu, D. (2010). Client importance, institutional improvements, and audit quality in China: an office and individual auditor level analysis. The Accounting Review, 85(1), 127-158.

Chi, W., Douthett, E., and Lei, L. (2010). Client importance and auditor independence: a partner-level analysis. Working paper, George Mason University.

Choi, J-H., Doogar, E.K., and Ganguly, A.R. (2004). The riskiness of large audit firm client portfolios and changes in audit liability regimes: evidence from the U.S. audit market. Contemporary Accounting Research, 21(4), 747-785.

Chung, H., and Kallapur,S. (2003). Client importance, nonaudit services, and abnormal accruals. The Accounting Review, 78(4), 931-955.

Commission on Public Trust and Private Enterprise. (2003). Findings and Recommendations Part 3: Audit and Accounting. New York, NY: The Conference Board.

Copley, A.P., and Doucet, M.S. (1993). The impact of competition on the quality of governmental audits. Auditing: A Journal of Practice \& Theory, 12 (1), 88-98.

Coppens, L., and Peek, E. (2005). An analysis of earnings management by European private firms. Journal of International Accounting, Auditing and Taxation, 14(1), 1-17.

Coulton, J., and Ruddock, C. (2007). The relation between nonaudit services and financial reporting quality at the partner level. Working paper, University of New South Wales.

Coulton, J., Ruddock, C., and Taylor, S. (2007). Audit fees, non-audit services and auditor-client economic bonding. Working paper, University of New South Wales.

Craswell, A., Francis, J., and Taylor, S. (1995). Auditor brand name reputations and industry specialization. Journal of Accounting and Economics, 20(3), 297-322.

D

Danos, P., and Eichenseher, J.W. (1982). Audit industry dynamics: factors affecting changes in client-industry market shares. Journal of Accounting Research, 20(2), 604-616.

Davidson, R.A., and Gist, W.E. (1996). Empirical evidence on the functional relation between audit planning and total audit effort. Journal of Accounting Research, 34(1), 111-124.

DeAngelo, H., and DeAngelo, L.E. (1991). Union negotiations and corporate policy: a study of labor concessions in the domestic steel industry during the 1980s. Journal of Financial Economics, 30(1), 3-43. 
DeAngelo, H., DeAngelo L.E., and Skinner, D.J. (1994). Accounting choice in troubled companies. Journal of Accounting and Economics, 17(1-2), 113-143.

DeAngelo, L.E. (1981a). Auditor independence, 'low balling', and disclosure regulation. Journal of Accounting and Economics, 3(3), 113-127.

DeAngelo, L.E. (1981b) Auditor size and audit quality. Journal of Accounting and Economics, 3(4), 183-199.

Dechow, P.M. (1994). Accounting earnings and cash flows as measures of performance: The role of accounting accruals. Journal of Accounting and Economics, 18(1), 3-42.

Dechow, P.M., Sloan, R., and Sweeney, A. (1995). Detecting earnings management. The Accounting Review, 70(2), 193-225.

DeFond, M.L., and Jiambalvo, J. (1994). Debt covenant violation and manipulation of accruals. Journal of Accounting and Economics, 17(1-2), 145-176.

DeFond, M.L., and Park, C.W. (2001). The reversal of abnormal accruals and the market valuation of earnings surprises. The Accounting Review, 76(3), 375-404.

Domberger, S., and Sherr, A. (1989). The impact of competition on pricing and quality of legal services. International Review of Law and Economics, 9(1), 41-56.

Dopuch, N., Gupta, M., Simunic, D., and Stein. M. (2003). Production efficiency and the pricing of audit services. Contemporary Accounting Research, 20(1), 47-78.

Dopuch, N., and Simunic, D. (1980). The nature of competition in the auditing profession: a descriptive and normative view. In: Buckley, J.W. and J.F. Weston (eds.), Regulation and the Accounting Profession (Lifetime Learning Publications).

Dye, R.A. (1988). Earnings management in an overlapping generations model. Journal of Accounting Research, 26(2), 195-235.

\section{E}

Ettredge, M.L., Xu, Y., and Yi, H. (2009). Fair value measurements, auditor industry expertise, and audit fees: evidence from the banking industry. Working paper: University of Kansas.

European Commission, (2010). Green paper. Audit policy: lessons from the crisis. Brussels: European Commission.

$\mathbf{F}$

Fama, E.F., and Jensen, M.C. (1983). Separation of ownership and control. Journal of Law and Economics, 26(2), 301-325.

Farmer, T.A., Rittenberg, L.E., and Trompeter, G.M. (1987). An investigation of the impact of economic and organizational factors on auditor independence. Auditing: A Journal of Practice and Theory, 6 (Fall): 114.

Ferguson, A., Francis, J.R., and Stokes, D.J. (2003). The effect of firm-wide and office-level industry expertise on audit pricing. The Accounting Review, 78(2), 429-448. 
Ferguson, A., Francis, J.R., and Stokes, D.J. (2006). What matters in audit pricing: industry specialization or overall market leadership? Accounting and Finance, 46(1), 97-106.

Ferguson, M.J., Seow, G.S., and Young, D. (2004). Nonaudit services and earnings management: UK Evidence. Contemporary Accounting Research, 21(4), 813-841.

Feroz, E.H., Park, K., and Pastena, V. (1991). The financial and market effects of the SEC's accounting and auditing enforcement releases. Journal of Accounting Research, 29(Supplement), 107-142.

Financial Stability Forum (FSF) (2006). Financial Stability Forum meets in Paris. Press Release, 6 September. Financial Stability Forum.

Financial Stability Forum (FSF) (2008). Report of the Financial Stability Forum on enhancing market and institutional resilience. Financial Stability Forum.

Fischer, P.E., and Stocken, P.C. (2004). Effect of investor speculation on earnings management. Journal of Accounting Research, 42(5), 843-870.

Francis, J.R. (1984). The effect of audit firm size on audit prices: a study of the Australian market. Journal of Accounting and Economics, 6(2), 133151.

Francis, J.R., and Krishnan, J. (1999). Accounting accruals and auditor reporting conservatism. Contemporary Accounting Research, 16(1), 135165.

Francis, J.R., Michas, P., and Seavey, S. (2010). Big Four Audit Market Concentration and Client Earnings Quality Around the World. Working paper, University of Missouri at Columbia.

Francis, J.R., and Reynolds, J.K. (2001). Do large accounting firms screen out risky clients? Working paper, University of Missouri at Columbia.

Francis, J.R., and Yu, M.D. (2009). The effect of Big four office size on audit quality. The Accounting Review, 84(5), 1521-1552.

Francis, J.R., Reichelt, K., and Wang, D. (2005). The pricing of national and city-specific reputations for industry expertise in the U.S. audit market. The Accounting Review, 80(1), 113-136.

Francis, J.R., Stokes, D.J., and Anderson, D. (1999). City markets as a unit of analysis in audit research and the re-examination of Big 6 market shares, Abacus, 35(2), 185-206.

Frankel, R.M., Johnson, M.F., and Nelson, K.K. (2002). The relation between auditor's fees for nonaudit services and earnings management. The Accounting Review, 77(4), 71-105.

G

Gaeremynck, A. and Willekens, M. (2003). The endogenous relationship between audit report type and business termination: evidence on private firms in a non-litigious environment. Accounting and Business Research, 33, 65-79.

Gaver, J.J., and Paterson, J.S. (2007). The influence of large clients on office-level auditor oversight: evidence from the property-casualty 
insurance industry. Journal of Accounting and Economics, 43(2-3), 299320.

Geiger, M. A., and Raghunandan, K. (2002). Auditor tenure and audit reporting failures. Auditing: A Journal of Practice and Theory, 21(1), 6778.

Ghosh, A., Kallapur, S., and Moon, D. (2009). Audit and non-audit fees and capital market perceptions of auditor independence. Journal of Accounting and Public Policy, 28(5), 369-385.

Gietzmann, M. B., and Quick, R. (1998). Capping auditor liability: the German experience. Accounting, Organizations \& Society, 23(1), 81-103.

Government Accountability Office (2003). Public accounting firms: mandated study on consolidation and competition. Report to the Senate Committee on Banking, Housing, and Urban Affairs and the House Committee on Financial Services.

H

Hackenbrack, K., and Knechel, W.R. (1997). Resource allocation decisions in audit engagements. Contemporary Accounting Research, 14(3), 481499.

Hair, J.F., Black, W.C., Babin, B.J., Anderson, R.E., and Tatham, R.L. (2006). Multivariate data analysis, 6th ed., Upper Saddle River, NJ: Prentice-Hall.

Hamilton, R.E., and Wright, W.F. (1982). Internal control judgment and effects of experience: replications and extensions. Journal of Accounting Research, 20(2), 756-765.

Hay, D., and Jeter, D. (2008). The pricing of industry specialization by auditors in New Zealand. Working paper, University of Auckland.

Hay, D. C., Knechel, W. R., and Wong, N. (2006). Audit fees: a metaanalysis of the effect of supply and demand attributes. Contemporary Accounting Research, 23(1), 141-191.

Healy, P.M., and Palepu, K.G. (2003). The fall of Enron. Journal of Economic Perspectives, 17(2), 3-26.

Hermanson, R.H., Dykes, L.M., and Turner, D.H. (1987). Enforced competition in the accounting profession - Does it make sense? Accounting Horizons, 1(4), 13-19.

Hooks, K., Cheramy, S., and Sincich, T. (1994). Methods used by Big-Six partners in practice development. Auditing: A Journal of Practice and Theory, 13(1), 101-114.

Hopwood, W., McKeown, J.C., and Mutchler, J.F. (1994). An examination of auditor versus model accuracy within the context of the going-concern opinion decision. Contemporary Accounting Research, 10(2), 409-431.

Houston, R.W., Peters, M.F., and Pratt, J.H. (1999). The audit risk model, business risk and audit-planning decisions. The Accounting Review, 74(3), 281-298.

Hribar, P., and Collins, D.W. (2002), Errors in estimating accruals: implications for empirical research. Journal of Accounting Research, 40(1), 105-134. 
Hribar, P., and Nichols, G.D. (2007). The use of unsigned earnings quality measures in tests of earnings management. Journal of Accounting Research, 45(5), 1017-1053.

Hunt, A.K., and Lulseged, A. (2007). Client importance and non-Big 5 auditors' reporting decisions. Journal of Accounting and Public Policy, 26(2), 212-248.

Huss, H.F., and Jacobs, F.A. (1991). Risk containment: exploring auditor decisions in the engagement process. Auditing: A Journal of Practice \& Theory, 10(2), 16-32.

I

IBR (2004). De Vennootschap en haar Commissaris: Praktische Toepssingsgevallen. IBR: Brussel.

International Federation of Accountants (IFAC), Handbook of International Standards on Auditing and Quality Control, New York, 2009 Edition.

lyer, V.M. and G.S. Iyer (1996). Effect of big 8 mergers on audit fees: evidence from the United Kingdom. Auditing: A Journal of Practice \& Theory, 15 (2), 123-132.

$\mathbf{J}$

Jensen, M.C., and Meckling, W.H. (1976). Theory of the firm: managerial behavior, agency costs and ownership structure. Journal of Financial Economics, 3(4), 305-360.

Johnson, E.N., K.B. Walker and E. Westergaard (1995). Supplier concentration and pricing of audit services in New Zealand, Auditing: $A$ Journal of Practice \& Theory, 14 (2), 74-89.

Johnson, V. E., Khurana, I.K., and Reynolds, J.K. (2002). Audit-firm tenure and the quality of financial reports. Contemporary Accounting Research, 19 (4), 637-660.

Johnstone, K.M. (2000). Client-acceptance decisions: simultaneous effects of client business risk, audit risk, auditor business risk, and risk adaption. Auditing: A Journal of Practice \& Theory, 19(2), 1-25.

Johnstone, K.M., and Bedard, J.C. (2001). Engagement planning, bid pricing, and client response in the market for initial attest engagements. The Accounting Review, 76(2), 199-220.

Johnstone, K.M., and Bedard, J.C. (2003). Risk management in client acceptance decisions. The Accounting Review, 78(4), 1003-1025.

Johnstone, K. M., and Bedard, J.C. (2004). Audit Firm Portfolio Management Decisions. Journal of Accounting Research, 42(4), 659-667.

Johnstone, K.M., Bedard, J.C., and Ettredge, M.L. (2004). The effect of competitive bidding on engagement planning and pricing. Contemporary Accounting Research, 21(1), 25-53.

Jones, J. (1991). Earnings management during import relief investigations. Journal of Accounting Research, 29(2), 193-228. 
$\mathbf{K}$

Kallapur, S., Sankaraguruswamy, S., and Zang, Y. (2008). Audit Market Competition and Audit Quality. Working paper, Indian School of Business.

Karmarkar, U.S., and Pitbladdo, R. (1995). Service markets and competition. Journal of Operations Management, 12, 397-411.

Khurana, I.D., and Raman, K.K. (2006). Do investors care about the auditor's economic dependence on the client? Contemporary Accounting Research, 23(4), 977-1016.

Kinney, W.R., Palmrose, Z-V., and Scholz, S. (2004). Auditor independence, non-audit services, and restatements: was the U.S. government right? Journal of Accounting Research, 42(3), 561-588.

Klein, B., and Leffler, K. (1981). The role of market forces in assuring contractual performance. Journal of Political Economy, 89(4), 615-641.

Knechel, W.R., and Vanstraelen, A. (2007). The relationship between audit tenure and audit quality implied by going concern opinions. Auditing: $A$ Journal of Practice \& Theory, 26(1), 113-131.

Kothari, S.P., Leone, A.J., and Wasley, C.E. (2005). Performance matched discretionary accruals measures. Journal of Accounting and Economics, 39(1), 163-197.

Kranton, R.E. (2003). Competition and the incentive to produce high quality. Economica, 70, 385-404.

Krishnan, G.V. (2003). Audit quality and the pricing of discretionary accruals. Auditing: A Journal of Practice \& Theory, 22(1), 109-126.

Krishnan, J., and Krishnan, J. (1997). Litigation risk and auditor resignations. The Accounting Review, 72 (4), 539-60.

$\mathbf{L}$

LaPorta, R., Lopez-de-Silanes, F., Schleiffer A., and Vishny R. (1998). Law and Finance. Journal of Political Economy, 106(6), 1113-1155.

LaPorta, R., Lopez-de-Silanes, F., Schleiffer, A., and Vishny R. (1997), Legal determinants of external finance. Journal of Finance, 52(3), 1131-1150.

Lefebvre, C., Van Nuffel, L., Lin, L. (1995). Financial and economic information to industrial relation councils in Belgium. Working paper, Catholic University of Leuven.

Leland, H.E. (1977). Quality choice and competition. American Economic Review, 67 (2), 127-137.

Leland, H.E. (1979). Quacks, lemons, and licensing: a theory of minimum quality standards. Journal of Political Economy, 87(6), 1328-1346

Leuz, C., Nanda D., and Wysocki, P. (2003). Earnings management and investor protection: an international comparison. Journal of Financial Economics, 69(3), 505-527.

Li, C. (2009). Does client importance affect auditor independence at the office level? Empirical evidence from going-concern opinions. Contemporary Accounting Research, 26(1), 201-230.

Libby, R., and Frederick, D.M. (1990). Experience and the ability to explain audit findings. Journal of Accounting Research, 28(2), 348-367. 
Liberty, S.E. and Zimmerman, J.L. (1986). Labor union contract negotiations and accounting choice. The Accounting Review, 61(4), 692-712.

Lys, T., and Watts, R. (1994). Lawsuits against auditors. Journal of Accounting Research, 32(Supplement), 65-93.

M

Maher, M.W., Tiessen, P., Colson, R., and Broman, A.J. (1992). Competition and audit fees. The Accounting Review, 67(1), 199-211.

Manry, D.L., Mock, T.J., and Turner, J.L. (2008). Does increased audit partner tenure reduce audit quality? Journal of Accounting, Auditing and Finance, 23(4), 553-572.

Marchant, G. (1990). Discussion of determinants of auditor expertise. Journal of Accounting Research, 28(3), 21-28.

Mautz, R.K., and Sharaf, H.A. (1961). The philosophy of auditing. American Accounting Association, Sarasota Springs.

Mazzeo, M.J. (2003). Competition and service quality in the U.S. airline industry. Review of Industrial Organization, 22, 275-296.

Mock, T.J., and Wright, A.M. (1993). An exploratory study of auditors' evidential planning judgments. Auditing: A Journal of Practice \& Theory, 12(2), 39-61.

Mock, T.J., and Wright, A.M. (1999). Are audit program plans risk-adjusted? Auditing: A Journal of Practice \& Theory, 18(1), 55-74.

Moizer, P. and Turley, S. (1987). Surrogates for audit fees in concentration studies. Auditing: A Journal of Practice \& Theory, 7(1), 118-123.

Mussa, M., and Rosen, S. (1978). Monopoly and product quality. Journal of Economic Theory, 18, 301-317.

Myers, J.N., Myers, L.A., and Omer, T.C. (2003). Exploring the term of the auditor-client relationship and the quality of earnings: a case for mandatory auditor rotation? The Accounting Review, 78(3), 779-799.

0

O'Keefe, T.B., Simunic, D.A. and Stein, M.T. (1994). The production of audit services: evidence from a major public accounting firm. Journal of Accounting Research, 32(2), 241-261.

Ohlson, J.A. (1980). Financial ratios and the probabilistic prediction of bankruptcy. Journal of Accounting Research, 18(1), 109-131.

Ooghe H., and Verbaere, E. (1982). Determinanten van faling: verklaring en predictie. Accountancy, Bedriffsfinanciering en Beleidsinformatie, RUG, 1166.

Ooghe, H., Joos, P., and De Bourdeaudhuij, C. (1995). Financial distress models in Belgium: the results of a decade of empirical research. International Journal of Accounting Education and Research, 30(3), 245274.

Owhoso, V.E., Messier, W.F., and Lynch, J.C. (2002). Error detection by industry-specialized teams during sequential audit review. Journal of Accounting Research, 40(3), 883-900. 
$\mathbf{P}$

Palmrose, Z.V. (1987). Litigation and independent auditors: the role of business failures and management fraud. Auditing: A Journal of Practice and Theory, 6, 90-103.

Palmrose, Z.V. (1988). An analysis of auditor litigation and audit service quality. The Accounting Review, 63 (1), 55-73.

PCAOB (2010). Application of the "failure to supervise" provision of the Sarbanes-Oxley act of 2002 and solicitation of comment on rulemaking concepts. Washington: Public Company Oversight Board.

Pearson, T. and Trompeter, G. (1994). Competition in the market for audit services: the effect of supplier concentration on audit fees. Contemporary Accounting Research, 11 (1-I), 115-135.

Pratt, J., and Stice, J.D. (1994). The effects of client characteristics on auditor litigation risk judgments, required audit evidence, and recommended audit fees. The Accounting Review, 69(4), 639-656.

Q

Quadackers, L., Mock, T.J., and Maijoor, S. (1996). Audit risk and audit programmes: archival evidence from four Dutch audit firms. The European Accounting Review, 5(2), 217-237.

$\mathbf{R}$

Raghunandan, W., Read, W.J., and Whisenant, J.S. (2003). Initial evidence on the association between nonaudit fees and restated financial statements. Accounting Horizons, 17(3), 223-234.

Reynolds, J.K., and Francis, J.R. (2001). Does size matter? The influence of large clients on office-level auditor reporting decisions. Journal of Accounting and Economics, 30(3), 375-400.

Ronnen, U. (1991). Minimum quality standards, fixed costs, and competition. RAND Journal of Economics, 22(4), 490-504.

S

Schelleman, C. and Knechel, W.R. (2010). Short-term accruals and the pricing and production of audit services. Auditing: A Journal of Practice and Theory, 29(1), 221-250.

Seetharaman, A., Gul F.A., and Lynn S.G. (2002). Litigation risk and audit fees: evidence from UK firms cross-listed on US markets. Journal of Accounting and Economics, 33(1), 91-115.

Sercu, P., Vander Bauwhede, H., and Willekens, M. (2002). Earnings quality in privately held firms: the roles of external audits, stakeholders, and governance mechanism. Working Paper, Katholieke Universiteit Leuven.

Shapiro, S.E., Lasarev, M.R., and McCauley, L. (2002). Factor analysis of Gulf War illness: what does it add to our understanding of possible health effects of deployment? American Journal of Epidemiology, 156(6), 578585.

Shepherd, W.G. (1990). The economics of industrial organisation. Prentice Hall, New Jersey, Englewood Cliffs. 
Shu, S.Z. (2000). Auditor resignations: clientele effects and legal liability. Journal of Accounting and Economics, 29(2), 173-205.

Sikka, P. (2009). Financial crisis and the silence of the auditors. Accounting, Organizations and Society, 34(6-7), 868-873.

Simunic, D.A. (1980). The pricing of audit services: theory and evidence. Journal of Accounting Research, 18(1), 161-190.

Simunic, D.A. (1984). Auditing, consultancy, and auditor independence." Journal of Accounting Research, 22(2): 679-702.

Simunic, D.A., and Stein, M.T. (1990). Audit risk in a client portfolio context. Contemporary Accounting Research, 6(2), 329-343.

Simunic, D.A., and Stein, M.T. (1996). The impact of litigation risk on audit pricing: a review of the economics and the evidence. Auditing: A Journal of Practice \& Theory, 15(Supplement), 119-134.

Sloan, R. (1996). Do stock prices fully reflect information in accruals and cash flows about future earnings? The Accounting Review, 71(3), 289315.

Spence, A.M. (1975). Monopoly, quality, and regulation. The Bell Journal of Economics, 6(2), 417-429.

St. Pierre, K., and Anderson, J. (1984). An analysis of the factors associated with lawsuits against public accountants. The Accounting Review, 59(2), 242-263.

T

Thoman, L. (1996). Legal damages and auditor efforts. Contemporary Accounting Research, 13(1), 275-306.

Tomczyk, S., and Read, W.J. (1989). Direct measurement of supplier concentration in the market for audit services. Auditing: A Journal of Practice and Theory, 9(1), 98-106.

Trueman, B., and Titman, S. (1988). An explanation for accounting income smoothing. Journal of Accounting Research, 26 (Supplement), 127-139.

V

Vander Bauwhede, H., and Willekens, M. (2004). Evidence on (the lack of) audit quality differentiation in the private client segment of the Belgian audit market. European Accounting Review, 13(3), 501-522.

Vander Bauwhede, H., Willekens, M., and Gaeremynck, A. (2003). Audit firm size, public ownership, and firm's discretionary accruals management. The International Journal of Accounting, 38(1), 1-22.

Vanstraelen, A. (2000). Impact of renewable long-term audit mandates on audit quality. The European Accounting Review, 9(3), 419-442.

Van Tendeloo, B., and Vanstraelen, A. (2008). Earnings management and audit quality in Europe: evidence from the private client segment market. The European Accounting Review, 17(3), 447-469.

W

Wallman, S.M.H. (1996). The future of accounting, part III: Reliability and auditor independence. Accounting Horizons, 10(4), 76-97. 
Warfield, T. D., Wild, J.J., and Wild, K.L. (1995). Managerial ownership, accounting choices, and informativeness of earnings. Journal of Accounting and Economics, 20 (1), 61-92.

Watts, R., and Zimmerman, J. (1981). The Markets for Independence and Independent Auditors. Working paper, University of Rochester, Rochester, NY.

White, H. (1980). A heteroskedasticity-consistent covariance matrix estimator and a direct test for heteroskedasticity. Econometrica, 48(4), 817-838.

Willekens, M., and Achmadi, C. (2003). Pricing and supplier concentration in the private client segment of the audit market: market power or competition? The International Journal of Accounting, 38, 431-455.

Willekens, M., and Vander Bauwhede, H. (2004). Auditor Reporting Conservatism as a Defense Mechanism against Increased post-Enron Litigation Risk. Working paper, Katholieke Universiteit Leuven.

Wingate, M.L. (1997). An examination of cultural influence on audit environments. Research in Accounting Regulation, Supp. 1, 129-148.

Y

Yardley, J.A., Kauffman, N.L., Cairney, T.D., and Albrecht, W.D. (1992). Supplier behavior in the U.S. audit market. Journal of Accounting Literature, 11, 151-184.

Young, S. (1999). Systematic measurement error in the estimation of discretionary accruals: An evaluation of alternative modeling procedures. Journal of Business Finance \& Accounting, 26(7), 833-862.

Z

Zeff, S.A., and Fossum, R. (1967). An analysis of large audit clients. The Accounting Review, 42(2), 298-320. 


\section{Summary in Dutch Nederlandse Samenvatting}

Dit proefschrift onderzoekt drie verschillende onderwerpen. Het eerste empirische stuk bestudeert of accountantskantoren gebruik maken van expertise van partners om risico's te beheersen die verbonden zijn aan accountantscontroles. Het tweede empirische stuk onderzoekt of economische afhankelijkheid van klanten de kwaliteit van accountantscontroles beïnvloedt. Het derde en laatste empirische stuk analyseert of de mate van concurrentie tussen accountants van invloed is op de kwaliteit van accountantscontroles.

Aangezien accountants, zoals aangetoond door Simunic en Stein (1990), hun complete klantenbestand in beschouwing nemen bij het nemen van beslissingen met betrekking tot individuele klanten is het van belang voor de empirische onderzoeken in dit proefschrift om gebruik te maken van een dataset waarin volledige portfolio's van klanten beschikbaar zijn. Bovendien is een vereiste voor het samenstellen van klantenbestanden dat het mogelijk is om te identificeren welk accountantskantoor, vestiging en partner verantwoordelijk zijn voor een accountantscontrole. Verder zijn gegevens over de expertise van accountants alsmede financiële gegevens vereist. Ten slotte zijn gegevens nodig over de geografische locaties van accountants en klanten, om de mate van concurrentie binnen lokale markten te bepalen. Aangezien de Belgische markt voor accountantscontroles aan al deze eisen voldoet, is dit een geschikte markt voor de studies in dit proefschrift. Voor de onderzoeken is daarom een dataset verzameld bestaande uit gegevens over alle accountantscontroles die uitgevoerd zijn in België tussen 1998 en 2006. De benodigde gegevens zijn verkregen via drie verschillende bronnen. Financiële gegevens zijn beschikbaar in de Bel-First databank. Gegevens over accountants zijn verkregen middels ledenlijsten van het Belgische instituut van de bedrijfsrevisoren (IBR). Tenslotte is gebruik gemaakt van Google Earth om geografische locaties van accountantskantoren en klanten te bepalen.

Zoals aangegeven onderzoekt het eerste empirische stuk of accountantskantoren gebruik maken van de verschillen in ervaringsniveaus van partners als een strategie voor risicobeheersing. Accountantskantoren kunnen de risico's verbonden aan accountantscontroles beheersen door middels van het toewijzen van partners met hogere mates van expertise aan meer risicovolle klanten. Bovendien vereisen controlestandaarden dat controleteams over voldoende ervaring beschikken. Ondanks dat het voor accountantskantoren van belang is dat partners met de meeste expertise worden toegewezen aan de meest risicovolle klanten, is het nog maar de vraag of dit in de praktijk gebeurt. Ten eerste is het toewijzingsproces van partners aan klanten erg complex vanwege de verschillen in ervaringsniveaus van partners en de variatie in risico karakteristieken van klanten. Tevens is risico aversie van partners mogelijk van negatieve invloed op hun bereidheid om risicovolle klanten te controleren. Dit zou er toe 
kunnen leiden dat relatief onervaren partners worden toegewezen aan de meeste risicovolle klanten.

Gebaseerd op voorgaand onderzoek onderscheidt deze studie twee verschillende maatstaven van expertise: algemene ervaring en branche specifieke ervaring. Drie verschillende typen risico's worden geanalyseerd: accountantscontrolerisico, ondernemingsrisico van klanten, en ondernemingsrisico van accountants. Accountantscontrolerisico en ondernemingsrisico van klanten worden gemeten aan de hand van financiële gegevens. Ondernemingsrisico van de accountant is afhankelijk van de vraag of een klant al dan niet beursgenoteerd is.

De resultaten laten zien dat accountants gebruik maken van algemene ervaring van partners, om het ondernemingsrisico van de accountant te beperken. De toewijzing van partners met meer branchespecifieke ervaring wordt gebruikt als strategie voor beheersing van accountantscontrolerisico. $\mathrm{Er}$ is geen bewijs gevonden voor de verwachting dat expertise van partners wordt gebruikt om het ondernemingsrisico van klanten te beperken. In zijn geheel genomen tonen de resultaten dat accountants gebruik maken expertise van partners als strategie voor risicobeheersing. Hier moet wel de kanttekening bij geplaatst worden dat ervaren partners wellicht ervoor kiezen om klanten met een hoog ondernemingsrisico voor de accountant te controleren vanwege prestige en carrière ontwikkelingsmogelijkheden verbonden met de controle van beursgenoteerde ondernemingen.

Het tweede empirische stuk bestudeert of economische afhankelijkheid van klanten de kwaliteit van accountantscontroles beïnvloedt. Accountantshonoraria kunnen leiden tot een economische band tussen de accountant en de klant. Dit zorgt er mogelijk voor dat de accountant minder onafhankelijk is van de klant, wat een lagere kwaliteit van de accountantscontrole ten gevolge zal hebben. Dit probleem speelt voornamelijk bij klanten die een relatief hoog honorarium betalen. In het geval dat de jaarrekening zoals goedgekeurd door de accountant materiële afwijkingen bevat kan dit nadelige effecten hebben op de reputatie van de accountant en bovendien kan de accountant aangeklaagd worden. Deze mogelijke gevolgen geven een stimulans voor de accountant om zich onafhankelijk op te blijven stellen, ongeacht de hoogte van het controlehonorarium (Reynolds en Francis 2001).

Aangezien problemen met betrekking tot verminderde onafhankelijkheid zich eerder voordoen op partner of lokaal kantoor niveau dan op het niveau van de gehele accountantsorganisitie, bestudeert deze studie de gevolgen van economische afhankelijkheid op de kwaliteit van de accountantscontrole op deze drie niveaus. Verder onderscheidt de studie ondernemingen die hun winsten naar boven sturen van ondernemingen die hun winsten naar beneden sturen. Dit verschil is van belang, aangezien de belastingdienst een hogere prioriteit geeft aan het controleren van jaarverslagen van ondernemingen controleert die hun winsten naar beneden sturen dan aan het controleren van jaarverslagen van ondernemingen die hun winsten naar boven sturen. Gegeven dat de Belgische markt een beperkt aansprakelijkheidsrisico kent, creëert dit de mogelijkheid om te bestuderen of reputatie effecten voldoende zijn voor accountantskantoren om zich onafhankelijk op te stellen, of dat er een behoefte is aan een publieke toezichthouder. 
Gebaseerd op eerder onderzoek maakt deze studie gebruik van een lineaire regressie om het effect van economische afhankelijkheid op de kwaliteit van de accountantscontrole te onderzoeken. Economische afhankelijk wordt gemeten op basis van de relatieve grootte van klanten binnen het klantenbestand van een accountant. De kwaliteit van de accountantscontrole wordt gemeten aan de hand van korte termijn accruals.

De resultaten van deze studie tonen aan dat economische afhankelijkheid een lagere kwaliteit van de accountantscontrole ten gevolge heeft. Deze bevinding is echter alleen van toepassing voor ondernemingen die hun winsten naar boven sturen. Accountants laten niet meer ruimte toe voor ondernemingen die hun winsten naar beneden sturen. Deze bevinding suggereert dat er een rol is weggelegd voor een publieke toezichthouder om de kwaliteit van accountantscontroles te garanderen. De resultaten tonen geen bewijs dat problemen qua onafhankelijkheid zich eerder voordoen op het niveau van de partner dan op het niveau van de accountantsorganisatie. Dit kan mogelijk verklaard worden door de geringe groottes van accountantskantoren in België.

Het laatste empirische stuk bestudeert het effect van concurrentie op de kwaliteit van de controle. Vanwege de hoge mate van concentratie wordt de markt voor accountantscontroles vaak bekritiseerd als zijnde een markt met beperkte concurrentie (e.g. Government Accountability Office 2003; Financial Stability Forum 2006). De algemene verwachting is dat een beperkte mate van concurrentie op een markt leidt tot een lage kwaliteit. Het is echter onduidelijk of dit ook van toepassing is op de markt voor accountantscontroles. Voorgaand onderzoek heeft aangetoond dat een hoge marktconcentratie niet per definitie gelijk staat aan een lage mate van concurrentie (Buijink et al. 1998). Bovendien is het niet duidelijk of standaard economische theoriën betreffende concurrentie en kwaliteit van toepassing zijn op accountantscontroles aangezien de kwaliteit van accountantscontroles niet direct waarneembaar is en bovendien is de markt voor accountantscontroles strikt gereguleerd.

In lijn met voorgaand onderzoek maakt de studie gebruik van de Herfindahl-index om de mate van marktconcentratie te meten. Tevens wordt een maatstaf van marktaandeel mobiliteit gebruikt om de mate van concurrentie te meten. Een tweede maatstaf van concurrentie, concurrentiedichtheid, wordt in deze studie geintroduceerd. Net zoals in de tweede studie maakt deze studie gebruik van korte termijn accruals om de kwaliteit van accountantscontroles te meten.

De resultaten van deze studie laten een negatief verband zien tussen marktconcentratie en de kwaliteit van accountantscontroles. Teven toont de studie een positief verband tussen de mate van concurrentie op de markt voor accountantscontroles en de kwaliteit van accountantscontroles. Deze bevinding suggereert dat concurrentie op de markt voor accountantscontroles mogelijk is, ongeacht de hoge mate van marktconcentratie.

Deze en verdere conclusies en aanbevelingen worden in hoofdstuk 5 weergegeven. Dit hoofdstuk geeft tevens een overzicht van de beperkingen van het onderzoek en suggesties voor toekomstig onderzoek. 



\section{Curriculum Vitae}

Jeroen van Raak was born on the 28th of June 1982 in Berkel-Enschot, The Netherlands. From 2000 to 2004 he studied business economics (with a specialization in accounting) at the Faculty of Economics and Business Administration at Tilburg University, where he graduated with distinction in November 2004. Following his graduation, he started working at Maastricht University as a research assistant. He began working on his dissertation in September 2005. Currently he is employed at Kozminski University in Warsaw, Poland. 